Prepared in cooperation with the Johnson County Stormwater Management Program

\title{
Quality of Streams in Johnson County, Kansas, 2002-10
}

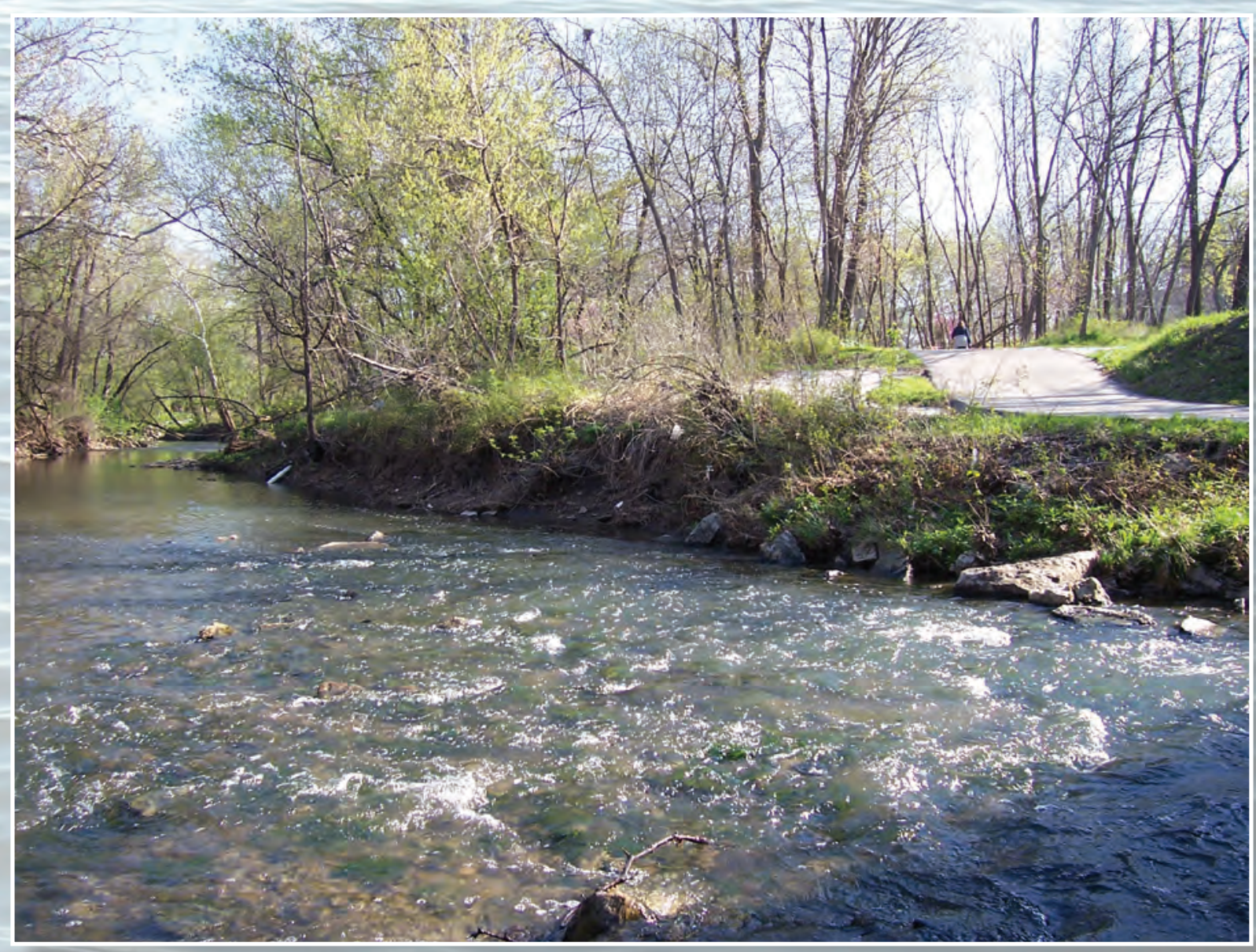

Scientific Investigations Report 2012-5279

U.S. Department of the Interior

U.S. Geological Survey 
Cover photograph: Indian Creek near College Boulevard in Johnson County, Kansas, April, 2010.

Back cover photographs: Upper left, Kill Creek downstream from 95th Street in Johnson County, Kansas, April, 2006. Lower right, Kill Creek upstream from 95th Street in Johnson County, Kansas, October, 2006. 


\section{Quality of Streams in Johnson County, Kansas, 2002-10}

By Teresa J. Rasmussen, Mandy S. Stone, Barry C. Poulton, and Jennifer L. Graham

Prepared in cooperation with the

Johnson County Stormwater Management Program

Scientific Investigations Report 2012-5279 


\title{
U.S. Department of the Interior \\ KEN SALAZAR, Secretary \\ U.S. Geological Survey \\ Marcia K. McNutt, Director
}

\author{
U.S. Geological Survey, Reston, Virginia: 2012
}

For more information on the USGS - the Federal source for science about the Earth, its natural and living resources, natural hazards, and the environment, visit http://www.usgs.gov or call 1-888-ASK-USGS.

For an overview of USGS information products, including maps, imagery, and publications, visit http://www.usgs.gov/pubprod

To order this and other USGS information products, visit http://store.usgs.gov

Any use of trade, firm, or product names is for descriptive purposes only and does not imply endorsement by the U.S. Government.

Although this information product, for the most part, is in the public domain, it also may contain copyrighted materials as noted in the text. Permission to reproduce copyrighted items must be secured from the copyright owner.

Suggested citation:

Rasmussen, T.J., Stone, M.S., Poulton, B.C., and Graham, J.L., 2012, Quality of streams in Johnson County, Kansas, 2002-10: U.S. Geological Survey Scientific Investigations Report 2012-5279, 103 p. 


\section{Contents}

Acknowledgements.........................................................................................................................

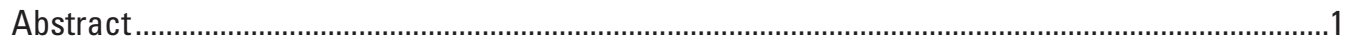

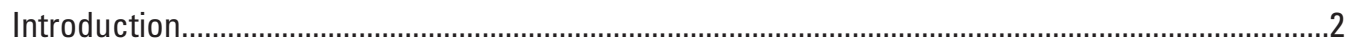

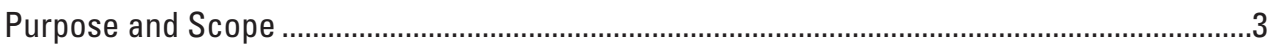

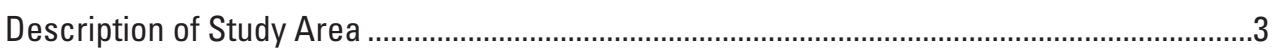

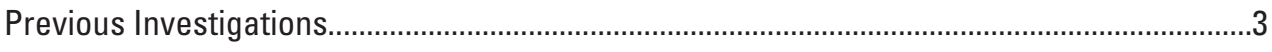

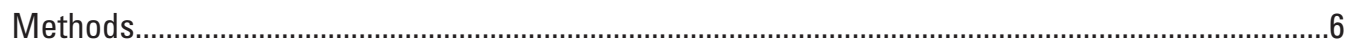

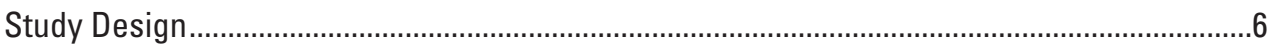

Data Collection and Laboratory Analyses ...............................................................................

Watershed Variables — Land Use, Streamflow, Precipitation ...........................................

Stream-Water and Streambed-Sediment Chemistry.......................................................7

Riparian and In-Stream Habitat...................................................................................

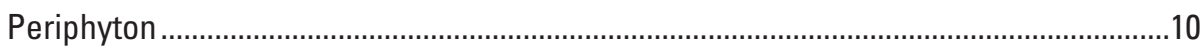

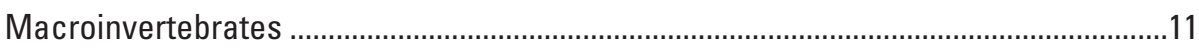

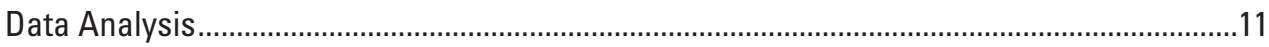

Streamflow Metric Data ..............................................................................................11

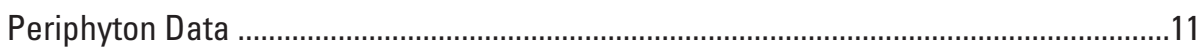

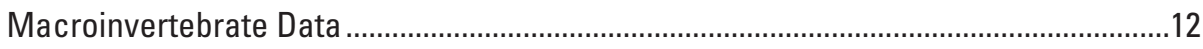

Relating Biological Data to Environmental Variables ...................................................13

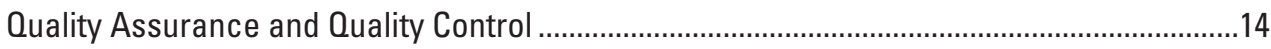

Water and Streambed-Sediment Data ..................................................................... 14

Periphyton Data ................................................................................................. 14

Macroinvertebrate Data ............................................................................................

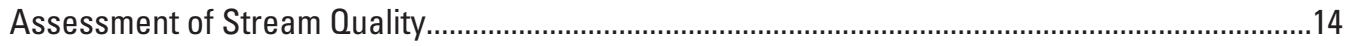

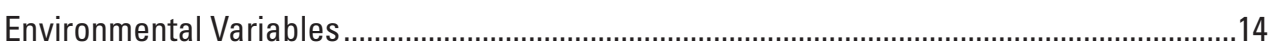

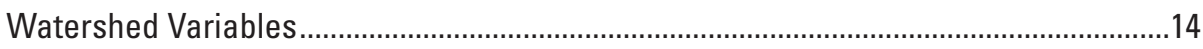

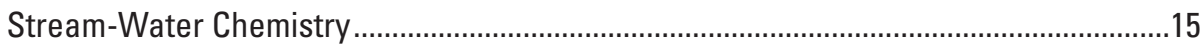

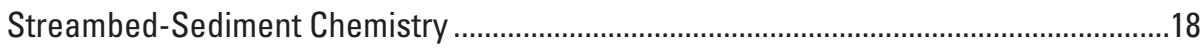

Riparian and In-Stream Habitat Conditions...................................................................20

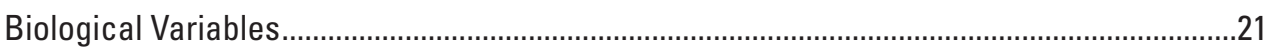

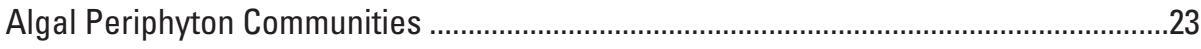

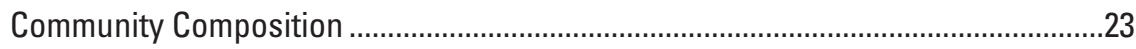

Periphyton Chlorophyll Concentrations, Abundance, and Biovolume....................23

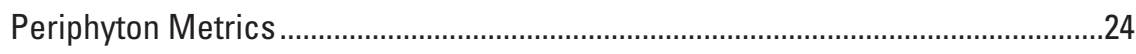

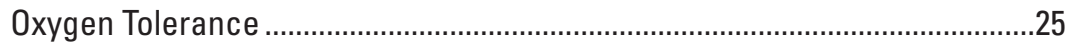

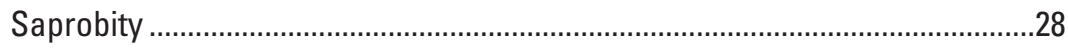

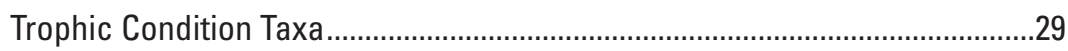

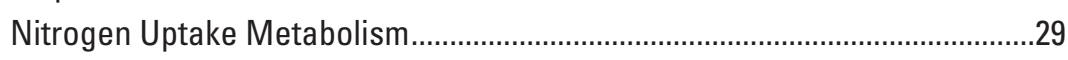

Diatom Indicator to Total Periphyton Biovolume .......................................................29

Macroinvertebrate Communities .....................................................................................29

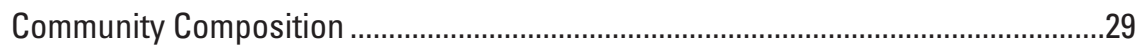

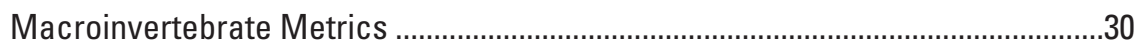

Macroinvertebrate Biotic Index (MBI) .........................................................30 


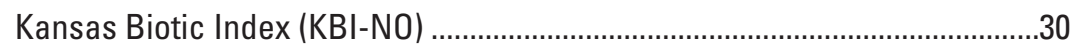

EPT Taxa Richness (EPTRich) ..........................................................................30

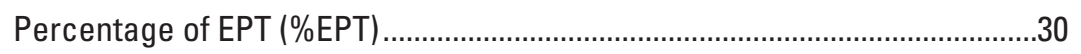

Total Taxa Richness (TRich) ..............................................................................31

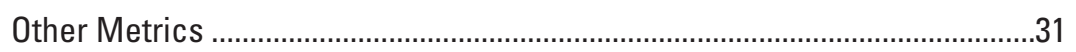

Combined 10-Metric Scores ………………………….....................................

Stream Quality Based on Aquatic-Life-Support Categories.....................................35

Comparison of Stream Biological Conditions Among Watersheds..........................36

Relations Between Stream Biological Conditions and Environmental Variables ....................37

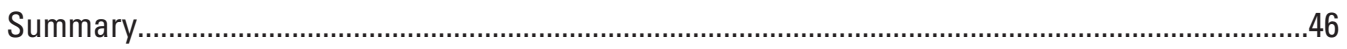

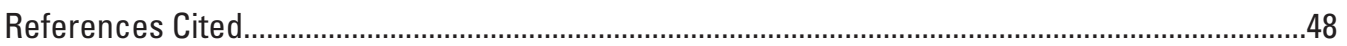

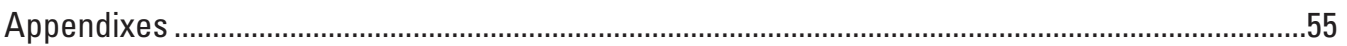

Appendix 1. Organic compounds analyzed in streambed sediment samples from biological monitoring sites in Johnson County, Kansas, 2003, 2007, and 2010 ............................56

Appendix 2. Summary of variables used to assess stream habitat conditions at biological monitoring sites in Johnson County, Kansas.

Appendix 3. Results of laboratory analysis for dissolved solids, major ions, nutrients, trace elements, suspended sediment, fecal-indicator bacteria, and organic compounds in water from biological monitoring sites in Johnson County, Kansas, 2002, 2003, 2007, and 2010

Appendix 4. Results of laboratory analysis for carbon, nutrients, trace elements and organic compounds in streambed-sediment samples from biological monitoring sites in Johnson County, Kansas, 2003, 2007, and 2010

Appendix 5. Scatter plots showing general relations between total organic carbon concentrations and selected constituents in streambed sediment at monitoring sites in Johnson County, Kansas, 2002-10.

Appendix 6. Periphyton taxa identified and the number of biological monitoring sites where each taxa occurred in Johnson County, Kansas streams during April 2010...............89

Appendix 7. Four most dominant periphyton taxa on the basis of abundance and the percentage contribution of each taxon to total abundance at biological monitoring sites in Johnson County, Kansas, during April 2010

Appendix 8. Four most dominant periphyton taxa on the basis of biovolume and the percentage contribution of each taxon to total biovolume at biological monitoring sites in Johnson County, Kansas, during April 2010.

Appendix 9. Macroinvertebrate taxa identified and the number of biological monitoring sites where each occurred in Johnson County, Kansas streams, 2003, 2004, 2007, and 2010

\section{Figures}

1. Map showing location of biological monitoring sites in Johnson County, Kansas, 2002-10

2. Map showing example of stream buffer land-use characterization near Mill Creek at 87th Street Lane in Johnson County, Kansas, showing land use and stormwater features within the 30-meter buffer zone

3. Photographs showing selected stream-monitoring sites and data-collection activities, including $A$, inventorying stormwater outfalls discharging into streams, $B$, collecting streambed-sediment sample, $C$, assessing streambed substrate using standardized frame, $D$, scrubbing periphyton from cobble surface, and $E$, sorting invertebrate samples 
4. Graph showing monthly and annual precipitation in Olathe, Kansas, 2003-10..

5. Graphs showing daily streamflow conditions 3 months before biological sampling in Johnson County, Kansas, and approximate period of sample collection, 2003, 2004, 2007, and 2010 .

6. Graphs showing selected water-quality characteristics during base flow sampling at monitoring sites in Johnson County, Kansas, 2002, 2003, 2007, and 2010.

7. Graphs showing concentrations of selected sediment-quality constituents in streambed samples collected during base-flow at monitoring sites in Johnson County, Kansas, 2003, 2007, and 2010

8. Graphs showing total habitat score and scores for selected individual habitat variables at biological monitoring sites in Johnson County, Kansas, 2010.

9. Graphs showing algal periphyton chlorophyll concentrations, abundance, and biovolume at biological monitoring sites in Johnson County, Kansas, 2007 and 2010.

10. Graph showing combined 10-metric macroinvertebrate scores for biological monitoring sites in Johnson County, Kansas, 2003, 2004, 2007, and 2010

11. Graph showing Kansas Department of Health and Environment aquatic-life-support status in relation to percent impervious surface area for biological monitoring sites in Johnson County, Kansas, 2003, 2004, 2007, and 2010

12. Maps showing anthropogenic disturbance maps for watersheds in $A$, Kansas, $B$, Johnson County, and $C$, Johnson County, with watershed disturbance scores rangestandardized among themselves

13. Map showing relative effects from human disturbance on stream health as indicated by 10-metric macroinvertebrate scores at biological monitoring sites in and near Johnson County, Kansas, 2003, 2004, 2007, and 2010.

14. Graphs showing invertebrate response patterns to urbanization as indicated by percent impervious surface at stream sites in Johnson County, Kansas, 2003, 2004, 2007, and 2010 .

15. Graph showing multidimensional scaling of macroinvertebrate abundance at stream biological monitoring sites in Johnson County, Kansas, 2007, 2010..

16. Graphs showing selected macroinvertebrate metrics (y) plotted against impervious surface area $(\mathrm{x})$ in the watersheds upstream from biological monitoring sites in Johnson County, Kansas, 2003, 2004, 2007, and 2010.

\section{Tables}

1. Site and drainage area characteristics of biological monitoring sites in Johnson County, Kansas, 2002-10, including estimated watershed area and upstream land use

2. Summary of streamflow metrics used in analyses of biological and environmental data for streams in Johnson County, Kansas.

3. List of macroinvertebrate metrics, abbreviations, and references used for assessment of biological conditions at monitoring sites in Johnson County, Kansas, 2010.

4. Streamflow statistics used in correlation analysis for biological monitoring sites in Johnson County, Kansas, 2002-2010

5. Results of habitat assessment at biological monitoring sites in Johnson County, Kansas 2010

6. Algal periphyton chlorophyll concentrations, abundance, and biovolume at biological monitoring sites in Johnson County, Kansas, March and July 2007 and April 2010.......24 
7. Periphyton metrics, conditions associated with each metric, and metric scores at biological monitoring sites in Johnson County, Kansas, April 2010.

8. Percentage contribution of diatom indicator taxa or groups of diatom indicator taxa to total periphyton biovolume at biological monitoring sites in Johnson County, Kansas, March and July 2007 and April 2010.

9. Macroinvertebrate metric and aquatic-life-support values for biological monitoring sites in Johnson County, Kansas, 2003, 2004, 2007, and 2010.

10. Spearman correlation matrix for selected biological and environmental variables using data from biological monitoring sites in Johnson County, Kansas, 2003, 2004, 2007, and 2010

11. Multiple linear regression models for biological monitoring sites in Johnson County, Kansas based on data collected in 2003, 2004, 2007, and 2010

\section{Conversion Factors}

\begin{tabular}{|c|c|c|}
\hline Multiply & By & To obtain \\
\hline \multicolumn{3}{|c|}{ Length } \\
\hline inch (in.) & 2.54 & centimeter $(\mathrm{cm})$ \\
\hline inch (in.) & 25.4 & millimeter $(\mathrm{mm})$ \\
\hline foot $(\mathrm{ft})$ & 0.3048 & meter $(\mathrm{m})$ \\
\hline mile (mi) & 1.609 & kilometer $(\mathrm{km})$ \\
\hline \multicolumn{3}{|c|}{ Area } \\
\hline square mile $\left(\mathrm{mi}^{2}\right)$ & 259.0 & hectare (ha) \\
\hline square mile $\left(\mathrm{mi}^{2}\right)$ & 2.590 & square kilometer $\left(\mathrm{km}^{2}\right)$ \\
\hline \multicolumn{3}{|c|}{ Volume } \\
\hline ounce, fluid (fl. oz) & 0.02957 & liter (L) \\
\hline million gallons (Mgal) & 3,785 & cubic meter $\left(\mathrm{m}^{3}\right)$ \\
\hline cubic foot $\left(\mathrm{ft}^{3}\right)$ & 0.02832 & cubic meter $\left(\mathrm{m}^{3}\right)$ \\
\hline \multicolumn{3}{|c|}{ Flow rate } \\
\hline foot per second (ft/s) & 0.3048 & meter per second $(\mathrm{m} / \mathrm{s})$ \\
\hline cubic foot per second $\left(\mathrm{ft}^{3} / \mathrm{s}\right)$ & 0.02832 & cubic meter per second $\left(\mathrm{m}^{3} / \mathrm{s}\right)$ \\
\hline $\begin{array}{l}\text { cubic foot per second per square } \\
\text { mile }\left[\left(\mathrm{ft}^{3} / \mathrm{s}\right) / \mathrm{mi}^{2}\right]\end{array}$ & 0.01093 & $\begin{array}{l}\text { cubic meter per second per } \\
\text { square kilometer }\left[\left(\mathrm{m}^{3} / \mathrm{s}\right) / \mathrm{km}^{2}\right]\end{array}$ \\
\hline million gallons per day (Mgal/d) & 0.04381 & cubic meter per second $\left(\mathrm{m}^{3} / \mathrm{s}\right)$ \\
\hline inch per hour (in/h) & 0.0254 & meter per hour $(\mathrm{m} / \mathrm{h})$ \\
\hline inch per year (in/yr) & 25.4 & millimeter per year $(\mathrm{mm} / \mathrm{yr})$ \\
\hline
\end{tabular}

Temperature in degrees Celsius $\left({ }^{\circ} \mathrm{C}\right)$ may be converted to degrees Fahrenheit $\left({ }^{\circ} \mathrm{F}\right)$ as follows: ${ }^{\circ} \mathrm{F}=\left(1.8 x^{\circ} \mathrm{C}\right)+32$

Specific conductance is given in microsiemens per centimeter at 25 degrees Celsius $(\mu \mathrm{S} / \mathrm{cm}$ at $25^{\circ} \mathrm{C}$ ).

Concentrations of chemical constituents in water are given either in milligrams per liter (mg/L) or micrograms per liter ( $\mu \mathrm{g} / \mathrm{L})$. 


\section{Acknowledgments}

The authors thank Kent Lage, Lee Kellenberger, and Heather Schmidt of the Johnson County Stormwater Management Program for support and planning related to sampling activities and gathering background information. The authors also thank Tony Holt and other staff members of the Johnson County Environmental Laboratory for cooperation related to sample analyses. The authors are grateful to Shannon Porter with Johnson County Automated Information Mapping System (AIMS) for providing land-use data, and to Layne Knight (Kansas Department of Health and Environment) for providing disturbance maps. 



\title{
Quality of Streams in Johnson County, Kansas, 2002-10
}

\author{
By Teresa J. Rasmussen, Mandy S. Stone, Barry C. Poulton, and Jennifer L. Graham
}

\section{Abstract}

Stream quality in Johnson County, northeastern Kansas, was assessed on the basis of land use, hydrology, stream-water and streambed-sediment chemistry, riparian and in-stream habitat, and periphyton and macroinvertebrate community data collected from 22 sites during 2002 through 2010. Stream conditions at the end of the study period are evaluated and compared to previous years, stream biological communities and physical and chemical conditions are characterized, streams are described relative to Kansas Department of Health and Environment impairment categories and water-quality standards, and environmental factors that most strongly correlate with biological stream quality are evaluated. The information is useful for improving water-quality management programs, documenting changing conditions with time, and evaluating compliance with water-quality standards, total maximum daily loads (TMDLs), National Pollutant Discharge Elimination System (NPDES) permit conditions, and other established guidelines and goals.

Constituent concentrations in water during base flow varied across the study area and 2010 conditions were not markedly different from those measured in 2003, 2004, and 2007. Generally the highest specific conductance and concentrations of dissolved solids and major ions in water occurred at urban sites except the upstream Cedar Creek site, which is rural and has a large area of commercial and industrial land less than 1 mile upstream on both sides of the creek. The highest baseflow nutrient concentrations in water occurred downstream from wastewater treatment facilities. Water chemistry data represent base-flow conditions only, and do not show the variability in concentrations that occurs during stormwater runoff.

Constituent concentrations in streambed sediment also varied across the study area and some notable changes occurred from previously collected data. High organic carbon and nutrient concentrations at the rural Big Bull Creek site in 2003 decreased to at least one-fourth of those concentrations in 2007 and 2010 likely because of the reduction in upstream wastewater discharge contributions. The highest concentrations of trace metals in 2010 occurred at urban sites on Mill and Indian Creeks. Zinc was the only metal to exceed the probable effects concentration in 2010, which occurred at a site on Indian Creek. In 2007, chromium and nickel at the upstream urban Cedar Creek site exceeded the probable effects concentrations, and in 2003, no metals exceeded the probable effects concentrations. Of 72 organic compounds analyzed in streambed sediment, 26 were detected including pesticides, polycyclic aromatic hydrocarbons (PAHs), fuel products, fragrances, preservatives, plasticizers, manufacturing byproducts, flame retardants, and disinfectants. All 6 PAH compounds analyzed were detected, and the probable effects concentrations for 4 of the 6 PAH compounds analyzed were exceeded in 2010. Only five pesticide compounds were detected in streambed sediment, including carbazole and four pyrethroid compounds. Chronic toxicity guidelines for pyrethroid compounds were exceeded at five sites.

Biological conditions reflected a gradient in urban land use, with the less disturbed streams located in rural areas of Johnson County. About 19 percent of sites in 2010 (four sites) were fully supporting of aquatic life on the basis of the four metrics used by Kansas Department of Health and Environment to categorize sites. This is a notable difference compared to previous years when no sites (in 2003 and 2004) or just one site (in 2007) was fully supporting of aquatic life. Multimetric macroinvertebrate scores improved at the Big Bull Creek site where wastewater discharges were reduced in 2007. Environmental variables that consistently were highly negatively correlated with biological conditions were percent impervious surface and percent urban land use. In addition, density of stormwater outfall points adjacent to streams was significantly negatively correlated with biological conditions. Specific conductance of water and sum of PAH concentrations in streambed sediment also were significantly negatively correlated with biological conditions. Total nitrogen in water and total phosphorus in streambed sediment were correlated with most of the invertebrate variables, which is a notable difference from previous analyses using smaller datasets, in which nutrient relations were weak or not detected. The most important habitat variables were sinuosity, length and continuity of natural buffers, riffle substrate embeddedness, and substrate cover diversity, each of which was correlated with all invertebrate metrics including a 10-metric combined score. Correlation analysis indicated that if riparian and in-stream habitat conditions improve then so might invertebrate communities and stream biological quality. Sixty-two percent of the variance in macroinvertebrate community metrics was explained by the single environmental factor, percent impervious surface. Invertebrate responses to urbanization in Johnson County indicated linearity rather than identifiable thresholds. Multiple linear regression models developed for each of the 
four macroinvertebrate metrics used to determine aquatic-lifesupport status indicated that percent impervious surface, as a measure of urban land use, explained 34 to 67 percent of the variability in biological communities.

Results indicate that although multiple factors are correlated with stream quality degradation, general urbanization, as indicated by impervious surface area or urban land use, consistently is determined to be the fundamental factor causing change in stream quality. Effects of urbanization on Johnson County streams are similar to effects described in national studies that assess effects of urbanization on stream health. Individually important environmental factors such as specific conductance of water, PAHs in streambed sediment, and stream buffer conditions, are affected by urbanization and, collectively, all contribute to stream impairments. Policies and management practices that may be most important in protecting the health of streams in Johnson County are those minimizing the effects of impervious surface, protecting stream corridors, and decreasing the loads of sediment, nutrients, and toxic chemicals that directly enter streams through stormwater runoff and discharges.

\section{Introduction}

Johnson County is one of the most rapidly developing counties in Kansas, with a population that has doubled during the past 30 years from about 270,000 in 1980 to about 543,000 in 2010 (U.S. Census Bureau, 2011). Countywide, about onehalf of the land is urban, and the potential for negative effects on streams is expected to intensify as many areas continue to populate. Johnson County streams are important for human and environmental health, water supply, recreation, and aesthetic value (ETC Institute, 2009).

Urban development generally affects streams by altering hydrology, geomorphology, water chemistry, ecosystem processes, and aquatic communities (Paul and Meyer, 2001). Hydrology is altered by increases in impervious surfaces, which increases stormwater runoff and the frequency and magnitude of large streamflow events (Leopold, 1968), and usually decrease base flows. Urban stream channels usually have increased streambed scour and bank erosion compared to channels in undeveloped areas (Hession and others, 2003) and also may have higher suspended-sediment concentrations (Walters and others, 2003), which can have negative effects on aquatic ecosystems (Waters, 1995). Urban streams can have increased concentrations and numbers of contaminants including metals, nutrients, dissolved solids, toxic organic compounds, and pathogens (Brown and others, 2009).

Useful benchmarks for evaluating stream health include state water-quality standards, total maximum daily loads (TMDLs), National Pollutant Discharge Elimination System (NPDES) permit requirements, and established national, state, and local guidelines including ecological targets. Waterquality criteria, which originate from national recommended criteria (U.S. Environmental Protection Agency, 2012) and state water-quality standards (Kansas Department of Health and Environment, 2005), include numeric goals for specified water properties and constituents including ammonia and other forms of nutrients, chloride, dissolved oxygen, fecal indicator bacteria, metals, organic compounds, and turbidity. The Kansas Department of Health and Environment (KDHE) also has established aquatic-life-support criteria (Kansas Department of Health and Environment, 2010a). In addition, the State has identified several streams in Johnson County as impaired (Kansas Department of Health and Environment, 2010b), and has established improvement goals as part of the TMDL program. Most stream impairments are related to excessive nutrients, sediment, or fecal bacteria. Provisions of the Clean Water Act require that urban stormwater runoff be controlled through the NPDES permit program, which is administered by the U.S. Environmental Protection Agency (USEPA) and implemented by individual States. As part of that program, Johnson County has established best management practices (BMPs) to reduce nonpoint-source pollution. An annual assessment is required to evaluate appropriateness of BMPs and to monitor progress toward the goal of reducing nonpoint-source pollution.

A comprehensive assessment of stream quality integrates multiple aspects of stream condition including climate, hydrology, land use, riparian and in-stream habitat, physical and chemical properties of water and streambed sediment, and aquatic biological communities. Climate affects hydrology, geomorphology, and biology and can help explain short-term and long-term variability in stream conditions. Streamflow regime describes magnitude, timing, duration, and frequency of high and low flows, which affect the structure and function of biological communities (Poff and Ward, 1989; Konrad and others, 2008). Habitat assessments evaluate the physical habitat characteristics that contribute to the quality of streams and the condition of the aquatic community (Barbour and others, 1996; Fitzpatrick and others, 1998). A decline in the quality and diversity of in-stream habitat generally is considered one of the primary stressors in aquatic systems (Karr and others, 1986). Water and streambed-sediment data allow evaluation of basic requirements for survival of aquatic biota and indicate whether applicable criteria or goals are being met. Sediment data provide information regarding fate, transport, and potential toxicity of chemicals that are associated with sediment, such as metals and wastewater compounds, and can be compared to sediment-quality guidelines. High concentrations of many contaminants in sediment can contribute significantly to toxic effects in the water column because sediment particles are re-suspended during large rain events (Christensen and others, 2006). Macroinvertebrate communities are important because their composition and community structure provide evidence of past physical and chemical conditions in a stream for a period of time. Periphyton consists of algae, bacteria, fungus, and other microorganisms that are attached to submerged substrates such as rocks and vegetation. Algal periphyton are primary producers and serve as an important food source for macroinvertebrates and some fish species. 
In part because of the sedentary nature of algal periphyton, these communities can be sensitive to changes in water quality and often are used as indicators of physical and chemical conditions.

Effective management of streams requires a thorough understanding of stream ecosystems and the factors affecting them. In 2002, the U.S. Geological Survey (USGS), in cooperation with the Johnson County Stormwater Management Program, began an investigation to characterize the quality of Johnson County streams and to provide information for use by municipalities in the development of water-quality management plans. In addition, results from this study may be used to evaluate compliance with water-quality standards, TMDLs, NPDES permits, and other established guidelines.

\section{Purpose and Scope}

The purpose of this report is to assess the quality of streams throughout Johnson County from 2002 to 2010. Aquatic biological communities and the environmental variables that may affect them are evaluated. Stream quality is characterized on the basis of watershed land use, streamflow, water and streambed-sediment chemistry, riparian habitat conditions, algal periphyton communities, and macroinvertebrate communities. Data collected during 2010 are used to describe conditions at the end of the study period and to evaluate changing conditions by making comparisons to data collected during 2002-06 (Wilkison and others, 2006; Poulton and others, 2007) and 2007 (Rasmussen and others, 2009). This report characterizes stream biological communities and physical and chemical conditions among stream sites and watersheds throughout the county, describes changes from 2002 to 2010, evaluates conditions relative to KDHE impairment categories and water-quality standards, and describes environmental factors that are most strongly correlated with biological stream quality.

\section{Description of Study Area}

The study area is Johnson County, which covers 477 square miles $\left(\mathrm{mi}^{2}\right)$ of land in northeastern Kansas. The county contains all or parts of 22 watersheds (HUC-14, Seaber and others, 1987), most of which are included within the monitoring network. Contaminants entering streams in both urban and rural areas of the county originate from point sources, such as municipal and industrial wastewater discharges, and from nonpoint sources including stormwater runoff, failing infrastructure, and atmospheric deposition. Because all sites are located within a small spatial area, natural variability caused by factors such as geology and climate is minimized. Average annual precipitation in the study area ranges from 38 to 40 inches (U.S. Department of Agriculture, 2007).

A total of 22 stream sites (table 1, fig. 1) representing a range in watershed size, urbanization and other land uses, and point and nonpoint contaminant sources were sampled during
2003, 2004, 2007, and 2010. Sixteen of the 22 sites were sampled in each of the 4 years. The remaining 6 sites were not sampled in 2003 and 2004, but were sampled in 2007, 2010, or both 2007 and 2010. Drainage areas upstream from monitoring sites range in size from $1.6 \mathrm{mi}^{2}$ to $65.7 \mathrm{mi}^{2}$. Countywide, about 50 percent of the county is urban, 10 percent is cropland, 30 percent is grassland, and 10 percent is woodland (calculated from 2005 Kansas Land Cover Patterns level 1 data, Peterson and others, 2010). The northeastern part of the county includes part of the Kansas City metropolitan area and is the most urbanized, whereas the western and southern parts of the county remain mostly undeveloped.

In 2010, 11 municipal wastewater treatment facilities (WWTFs) were located in watersheds upstream from monitoring sites, and 6 of the WWTFs had a discharge capacity of more than one million gallons per day (gpd). Eight of the monitoring sites are located downstream from wastewater discharge(s), with distances ranging from 0.6 river miles (IN3a) to about 13 miles (KI6b, MI7) from the upstream WWTF. One site (BR2) is affected by a wastewater bypass discharge directly upstream, which occurs periodically when sewage line capacities are exceeded during stormwater runoff.

\section{Previous Investigations}

The quality of streams in Johnson County has been the subject of earlier assessments. A study of the effects of wastewater discharge on biological conditions in the upper Blue River in Johnson County (Graham and others, 2010) indicated that the largest differences between sites upstream and downstream from wastewater discharge were in nutrient concentrations, which were significantly higher downstream, particularly during normal and below-normal streamflows. Aquatic-life-support scores were significantly lower downstream, and ecosystem functional health (assessed on the basis of biological productivity) was mildly impaired downstream from the wastewater discharge.

Macroinvertebrate communities in Johnson County streams were described by Poulton and others (2007) using data collected in 2003 and 2004. A subsequent assessment of macroinvertebrate and periphyton communities was completed using data collected in 2007 (Rasmussen and others, 2009). Results indicated that biological condition generally reflected a gradient in the degree of human disturbance upstream from sites. Environmental factors that most strongly correlated with stream biological conditions included amount of upstream urbanization, specific conductance of stream water, concentration of polycyclic aromatic hydrocarbons (PAHs) in streambed sediment, and habitat variables related to riparian buffer condition and sediment deposition.

Chemical concentrations, loads, and yields in five principal Johnson County streams were described using data and statistical models based on continuous water-quality monitoring during 2002-06 (Rasmussen and others, 2008). Concentrations of suspended sediment, chloride, and fecal-indicator bacteria generally were higher in more urban watersheds than 


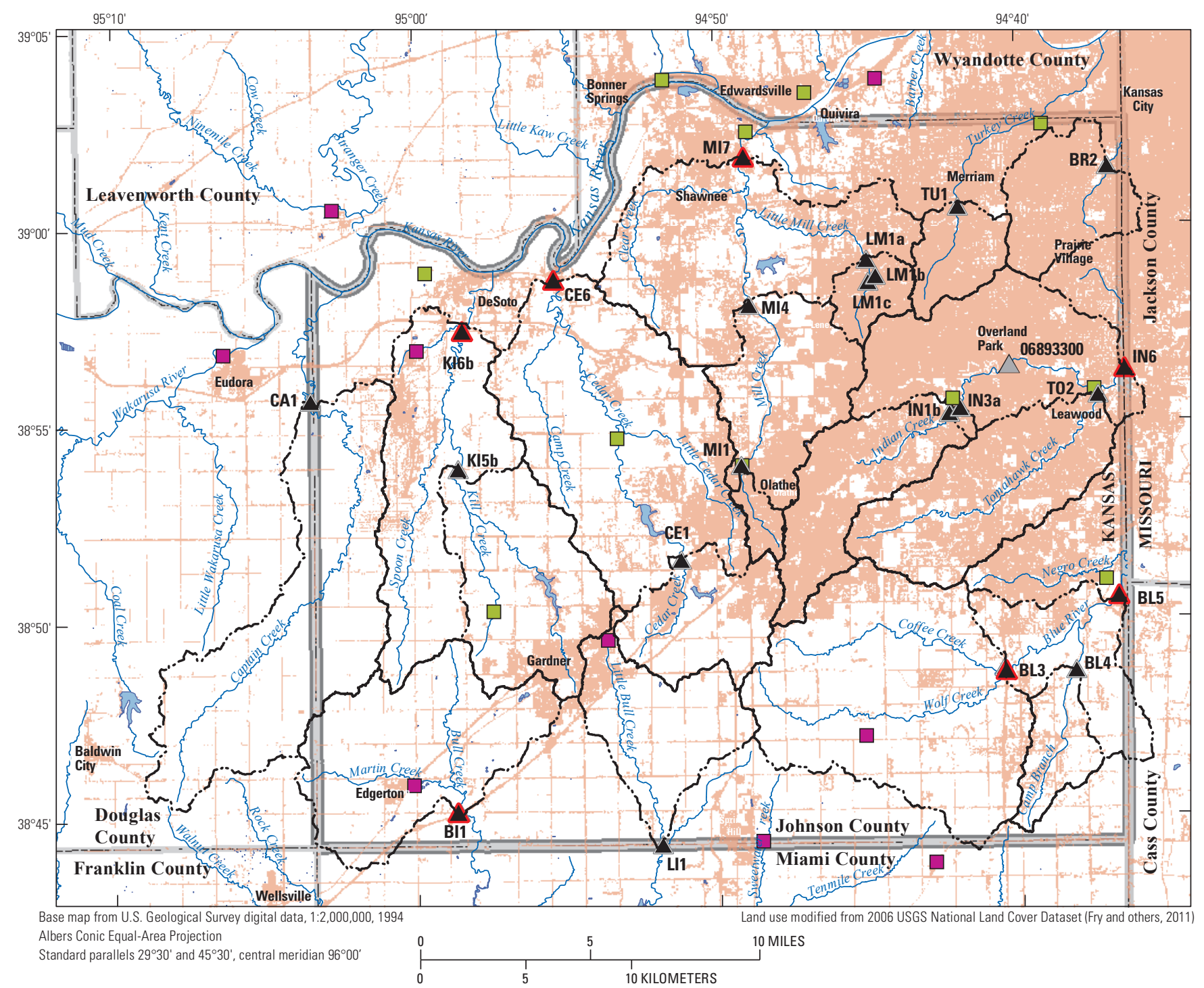

EXPLANATION
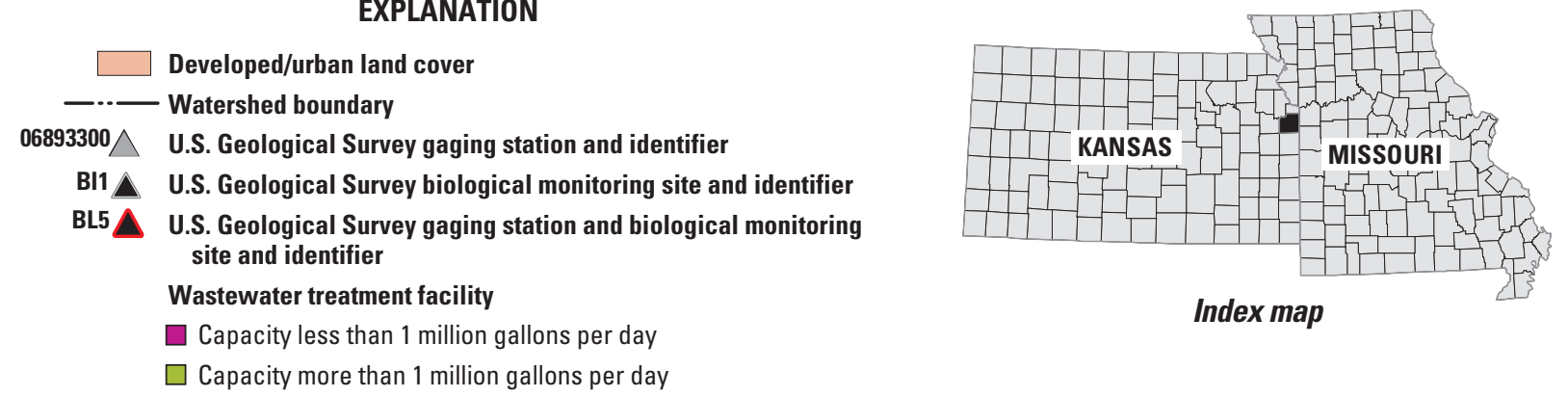

Index map

Figure 1. Location of biological monitoring sites in Johnson County, Kansas, 2002-10.

in nonurban watersheds and were substantially higher during periods of increased streamflow. At least 90 percent of the total suspended-sediment load during 2005-06 in all five watersheds was transported in less than 2 percent of the time during periods of increased streamflow.

Lee and others (2005) described the effects of contaminant sources on stream-water quality using samples collected during 2002-04. Results indicated that during base flow, discharge from WWTFs comprised more than one-half of streamflow at sampling sites located downstream from wastewater discharges, and concentrations of nutrients and household organic compounds generally were higher downstream from WWTFs. In addition, stormflow samples contained the highest suspended-sediment concentrations and fecal-indicator bacteria densities.

Assessments of water quality in Kansas City, Missouri, using data collected during 1998 through 2007 included some upstream sites in Johnson County (Wilkison and others, 2002, 


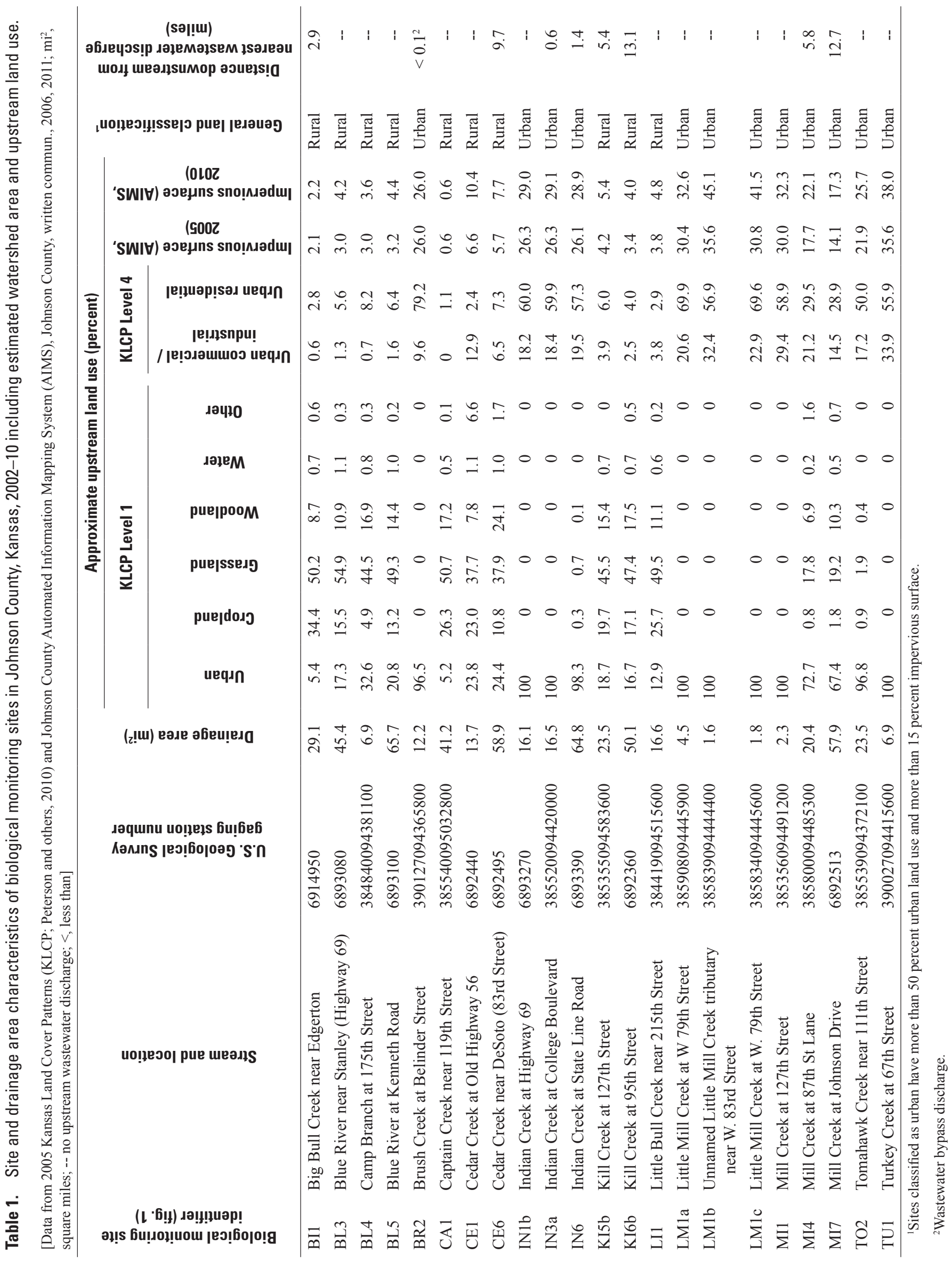


2006, and 2009). Primary sources of nutrients were nonpointsource runoff and WWTFs, with relative contributions dependent upon annual precipitation. Declines in aquatic community diversity and abundance followed a trend of increasing urbanization and generally were accompanied by similar declines in stream physical habitat quality.

\section{Methods}

\section{Study Design}

Data describing watershed variables (land use, streamflow, and precipitation), stream-water and streambed-sediment chemistry, riparian and in-stream habitat, algal periphyton, and macroinvertebrates were collected to provide a comprehensive dataset for evaluating stream biological conditions and the environmental variables that may affect them. Sites initially were selected to represent all of the primary watersheds in the county, and to be representative of various land-use types, extent of urbanization, and sources of streamflow, including wastewater discharges, to fully characterize stream condition and important environmental factors. Water, streambed sediment, periphyton, and macroinvertebrates were collected during base-flow conditions in early spring of each sampled year. Samples were collected in early spring to be consistent with previously collected data and to try to precede pulses of spring runoff that may disrupt biological communities. In addition, macroinvertebrate samples collected from small streams in late winter and early spring often have more diversity compared to samples collected in other seasons (Feminella, 1996) because emergence periods of many stream insects occur during that time. Base flow is defined as the sustained low flow of a stream in the absence of direct runoff, and usually originates from groundwater seepage, springs, and wastewater discharges. Because water samples were collected during base flow only, water chemistry data do not show the variability in concentrations that occurs during stormwater runoff (Rasmussen and others, 2008). Habitat assessments were completed at each site in 2007 and 2010 during late summer or early fall before trees started to lose their leaves. The only candidate reference stream located in the county, Captain Creek (Kansas Department of Health and Environment, 2010a), was included in the study. Reference streams are streams designated by the State as being minimally disturbed by human activity. Examples of possible human disturbance include urban or agricultural runoff, municipal or industrial discharges, riparian or in-stream habitat alterations, and changes to hydrologic regime.

Most stream monitoring sites were located at, or near, bridge crossings. Water samples were collected at bridge crossings where available, and at designated stream crosssections where bridges were not available. Streambed sediment, periphyton, and macroinvertebrate samples were collected from the stream sections (the reaches) located directly upstream from water sampling sites. The reach length for each site was determined so as to include at least two riffle-pool sequences and as many different in-stream and riparian habitat types as possible. Each reach was a minimum of 450 feet (ft) and no more than $900 \mathrm{ft}$ in length. Habitat information was collected primarily at the reach scale, but also incorporated some segment-scale measurements. The stream segment was defined as a section of stream that is relatively homogeneous with respect to physical, chemical, and biological properties and generally bounded by tributary junctions, point-source discharges, or other features that might be expected to change stream properties (Fitzpatrick and others, 1998). The upstream boundary of the segment was defined by a change in stream order (Strahler, 1957) or presence of wastewater discharge.

For most analyses, data collected in 2010 were either compared or combined with data collected in 2003, 2004, and 2007 to evaluate patterns, relations, or trends among variables. Data from previous years were collected generally by following the same protocols as were used in 2010. Biological samples collected during 2003 and 2004 were not collected concurrently with base-flow water and streambed-sediment samples as was done in 2007 and 2010. Therefore, water and streambed-sediment data from 2002 and 2003 are presented to provide information about general stream chemistry at the sites, but they do not represent conditions during biological sampling and were not used in correlation analyses. Previous study designs, data collection, analyses, and results are described in detail by Lee and others (2005), Poulton and others (2007), and Rasmussen and others (2009).

\section{Data Collection and Laboratory Analyses}

Land use, hydrology, stream-water and streambed-sediment chemistry, riparian and in-stream habitat, and periphyton and macroinvertebrate community data were collected from 22 stream sites located across Johnson County. Samples were collected from 16 sites in 2003, 2004, 2007, and 2010. The remaining six sites were sampled only in 2007 or 2010 , or both. Data types included in collection were either indicators of biological stream condition (macroinvertebrates and periphyton) or measures of factors that could help explain biological stream condition.

\section{Watershed Variables_-Land Use, Streamflow, Precipitation}

Estimates of land-use percentages were determined for all biological monitoring sites at several different scales. Land-use percentages were determined for the watershed area upstream from each site using data derived from the 2006 National Land Cover Database (NLCD: Fry and others, 2011) and 2005 Kansas Land Cover Patterns (KLCP; Kansas Applied Remote Sensing, 2006; Peterson and others 2010) and included areas where watersheds crossed outside county boundaries. For some analyses, comparison sites generally 
were classified as urban or rural according to urban land use and impervious surface area. Sites classified as urban had more than 50 percent urban land use and more than 15 percent impervious surface area. Land-use percentages also were calculated at each site for 30-meter buffers on each streambank (fig. 2) for the length of the reach, the segment, and the full extent of the stream upstream from monitoring sites using 2008 data obtained from Johnson County AIMS (Johnson County, written commun., 2006) and derived from true-color orthophotography during leaf-off conditions with a resolution of $0.5 \mathrm{ft}$. Minor modifications were made to the 2008 AIMS data (Johnson County, written commun., 2011) to best represent 2010 conditions after making comparisons to 2010 imagery. Different scales were used for estimating land use to better characterize land areas that might affect stream conditions. For example, Calhoun and others (2008) documented that algal assemblages were more associated with watershed land use farther from the streams, and macroinvertebrate communities were better associated with land use near the sampled stream reach. Although wider buffer areas have been documented to correlate with better stream quality (as wide as 150 meters, Zelt and Munn, 2009), 30-meter buffers were characterized in this study because of buffer improvement implementation feasibility within a smaller buffer zone, particularly in developed urban areas. Impervious surface areas were estimated using AIMS data supplemented by the other data where watersheds crossed outside the boundaries of Johnson County. The 2005 and 2010 impervious surface data provide the best available quantification of changes in urban land use during the study period. Impervious surface area was calculated by adding total area of all buildings, courtyards, paved and unpaved roads, driveways, parking lots, and airport runways, but not including sidewalks or biking paths. Land use classified as cropland refers to row crops. Stormwater outfalls (fig. $3 A$ ) adjacent to streams also were used to characterize stream buffers (fig. 2).

USGS streamflow gages were in operation at 7 of the 22 monitoring sites (fig. 1). Streamflow data for these gages were examined for the 3 months before sampling to help interpret macroinvertebrate and periphyton data. Hourly precipitation data, which were collected along with streamflow at USGS gaging sites, also were used to assess patterns before sampling and to compare conditions among sites. Monthly and annual precipitation data from 1999-2010 at the Olathe Johnson County Executive Airport located in central Johnson County, obtained from National Oceanic and Atmospheric Administration (National Oceanic and Atmospheric Administration, 2011), were used to evaluate general precipitation conditions during the study period compared to a longer period-of-record.

\section{Stream-Water and Streambed-Sediment Chemistry}

Stream-water and streambed-sediment samples (fig. 3B) were collected during March 12-15, 2007, and April 5-9, 2010, on the same day that invertebrate and periphyton samples were collected at each site. Water and streambed-sediment samples were not collected concurrently with biological samples during 2003 and 2004. Water data collected during November 4-7, 2002, and July 14-18, 2003, are included in the study to provide water chemistry information antecedent to the first biological sample collection in March 2003. Streambed-sediment samples were not collected in 2003, but were collected during March 31-April 3, 2004, about 2 weeks after macroinvertebrate samples were collected.

Water samples were collected during base-flow conditions using equal-width-increment (EWI) methods (U.S. Geological Survey, 2006) at sites with adequate stream depth (at least about $0.5 \mathrm{ft}$ ) and using grab samples collected at the centroid of flow for other sites. Samples collected using EWI methods were composited in a churn from isokinetic and depth-integrated subsamples. Aliquot samples were processed and preserved on-site according to USGS protocols (U.S. Geological Survey, 2006). Streambed-sediment samples were collected during base-flow conditions from the upper $0.8 \mathrm{in}$. of deposits using Teflon scooping utensils. The top layer of the finest deposited material, optimally less than 63 micrometers $(\mu \mathrm{m})$, was removed from 6 to 10 separate depositional zones along the streambed and placed in a glass container, homogenized, split into aliquots for different laboratories, and shipped chilled for analysis (Pope, 2005; Radtke, 2005).

Water samples were analyzed for suspended sediment, dissolved solids, major ions, nutrients, trace elements, fecalindicator bacteria (Escherichia coli, enterococci, and fecal coliform), and pesticide compounds. Suspended-sediment concentration was determined at the USGS Sediment Laboratory in Iowa City, Iowa, according to methods described by Guy (1969). Major ions, nutrients, and fecal-indicator bacteria were analyzed at the Johnson County Environmental Laboratory in Johnson County, Kansas, according to standard methods (American Public Health Association and others, 1995), and replicate samples were sent to the USGS National Water Quality Laboratory (NWQL) in Lakewood, Colorado, and analyzed according to methods presented in Fishman and Friedman (1989).

Streambed-sediment samples were analyzed for total organic carbon, total carbon, major ions, nutrients, trace elements, pesticides including pyrethroids, and organic wastewater compounds. Pyrethroid insecticides were added to the laboratory analysis in 2010 because these synthetic compounds are highly toxic to fish and invertebrates (Hill, 1989) and have become more common in urban and rural areas as a replacement for previously common organophosphate insecticides such as diazinon and chlorpyrifos (Hladik and others, 2009). Analysis for carbon, major ions, nutrients, and trace elements in sediment was performed at the USGS sediment research laboratory in Atlanta, Georgia according to methods described by Horowitz and others (2001). Pyrethroid compounds were analyzed at the USGS research laboratory in Sacramento, Calif., following methods described by Hladik and others (2009). Pesticides and organic wastewater compounds in streambed sediment were analyzed by NWQL according 


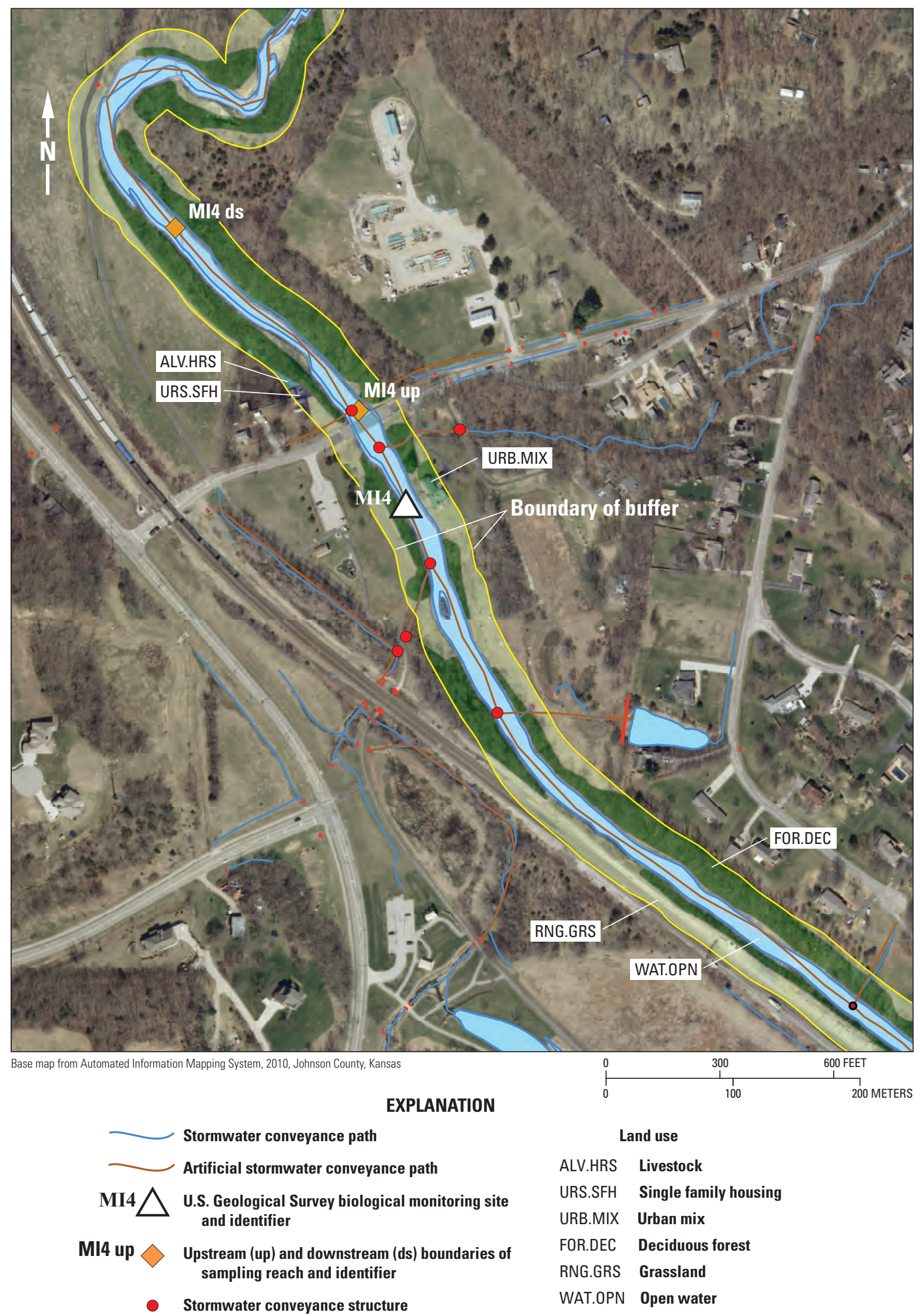

Figure 2. Example of stream buffer land-use characterization near Mill Creek at 87th Street Lane in Johnson County, Kansas, showing land use and stormwater features within the 30-meter buffer zone. 

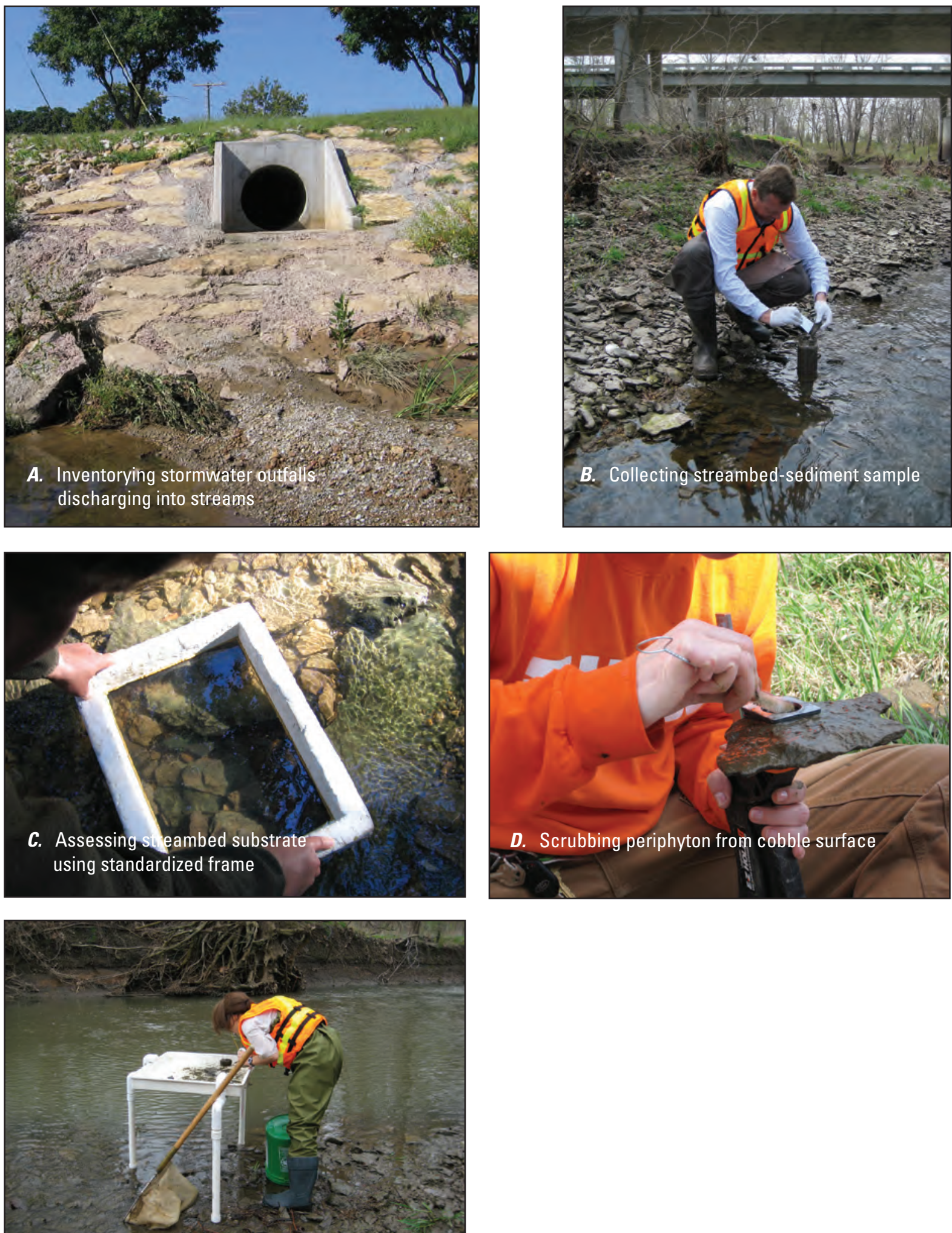

E. Sorting invertebrate samples

Figure 3. Photographs showing selected stream-monitoring sites and data-collection activities, including $A$, inventorying stormwater outfalls discharging into streams, $B$, collecting streambed-sediment sample, $C$, assessing streambed substrate using standardized frame, $D$, scrubbing periphyton from cobble surface, and $E$, sorting invertebrate samples. 
to methods described by Foreman and others (1995) and Burkhardt and others (2006). Many organic compounds that were analyzed were not detected and, therefore, not included in results discussed in this report; the complete list of organic analytes in sediment is included as appendix 1 .

In 2010, all sediment analyses were done only on the particle-size fraction of the sediment sample finer than $63 \mu \mathrm{m}$ in diameter (silt and clay) to minimize effects of sediment-size differences on chemical concentrations. All samples collected in 2010 were wet-sieved at the laboratory, homogenized, then split into subsamples and shipped to the USGS NWQL and USGS California laboratories for analysis of organic compounds. In 2003 and 2007, samples sent to the Georgia sediment laboratory were sieved before analysis, as in 2010; but analyses performed by NWQL for organic compounds were done on unsieved bulk samples in 2003 and 2007. No adjustments were made to organic compound data to account for effects of differences in particle-size fractions among sampling years; consequently, results for making comparisons between earlier samples collected in 2003 and 2007, and most recent samples collected in 2010, likely contain an unquantified bias.

\section{Riparian and In-Stream Habitat}

Riparian and in-stream habitat characteristics were evaluated during September 2007 and October 2010 at each site using methods described in detail by Rasmussen and others (2009) (appendix 2). The protocol used is similar to USEPA's Rapid Habitat Assessment Protocol (RHAP, Barbour and others, 1999) but slightly modified to provide more information about stream types in the study area. A total of 17 habitat variables in 3 general categories (channel conditions and characteristics, bank and riparian conditions, and aquatic habitat availability) were evaluated (fig. 3C). Data collection was completed using a combination of field measurements and surveys, aerial imagery, and topographic maps.

Each habitat variable was assigned a score on a scale of 1 to 12 (Rasmussen and others, 2009) and all habitat variables were integrated into 1 total site score by summing each of the individual scores. To simplify comparisons, scores were standardized to a scale of 0 to 100 by dividing each score by the total possible score and multiplying by 100 . Four rating categories of relative quality (as described by Rasmussen and others, 2009) were used to evaluate habitat conditions and make comparisons among sites.

\section{Periphyton}

Periphyton samples were collected from stream sites during March 12-15, 2007, July 23-26, 2007, and April 5-12, 2010. Because the stream substrates along the study reaches are dominated by gravel and cobble, cobble substrate in riffles and runs was sampled for periphyton at each site. This single habitat sampling approach minimizes periphyton variability among sites caused by sampling of different habitats (Stevenson and Bahls, 1999; Moulton and others, 2002).

Periphyton samples were collected by compositing material from 15 randomly selected cobbles collected from three adjacent riffles at each site. If three riffles were not present, unattached hard substrates (cobbles or woody debris) from run habitats were used. All field sampling equipment was vigorously rinsed three times with stream water. Cobbles were selected and transported from the stream to an on-site processing station. Using a bar-clamp sampler and a new test tube brush at each site, periphyton samples were scraped (scrubbed) from a known area of the cobble surface (device scrubs equivalent areas for each sample) and rinsed into a beaker with filtered stream water (fig. $3 D$ ). This process was repeated several times until all of the visible periphyton was removed from the sampling area of each cobble.

After all cobbles were scraped, periphytic material was rinsed from the beaker into a graduated cylinder. Sample volume was recorded and the sample was poured into a 1-liter high density polyethylene (HDPE) amber bottle (Stevenson and Bahls, 1999; Moulton and others, 2002; Hambrook-Berkman and Canova, 2007). The sample was vigorously shaken and split into three aliquots. Two aliquots were processed for chlorophyll determination and one for taxonomic identification and enumeration. Chlorophyll samples were processed as described in Hambrook-Berkman and Canova (2007). Samples for taxonomic identification and enumeration were preserved with a 9:1 Lugol's iodine:acetic acid solution. The known areas for all 15 cobbles in a sample were summed to determine total surface area sampled.

Chlorophyll was analyzed at the USGS Kansas Water Science Center, Lawrence, Kans. Total chlorophyll (uncorrected for degradation products) was extracted in heated ethanol (Sartory and Grobbelar, 1986) and analyzed by fluorometry using EPA method 445.0 (Knowlton, 1984; Arar and Collins, 1997). Samples were analyzed in duplicate and results are reported as averages of the duplicates.

BSA Environmental Services, Inc., Beachwood, Ohio, analyzed periphyton samples for taxonomic identification, enumeration, and biovolume of diatoms and soft algae. Diatoms were counted by natural unit as a general category then examined in permanent diatom mounts. Diatom slides were made using the traditional nitric acid digestion method (Patrick Center for Environmental Research, 1988) and a minimum of 400 valves were identified to the lowest possible taxonomic level. The soft algae were enumerated to the lowest possible taxonomic level using membrane-filtered slides (McNabb, 1960) and a minimum of 400 natural units were counted. Biovolume is an estimate of algal biomass and was calculated using mean measured cell dimensions. Biovolume factors for diatoms and soft algae were calculated using methods in Hillebrand and others (1999). Diatom biovolumes were calculated from permanent slides. A mean biovolume measurement per cell was calculated for each sample and that value was used as the biovolume measurement in the general diatom category. 


\section{Macroinvertebrates}

Macroinvertebrate samples were collected from sites during March 4-13, 2003; February 24-March 3, 2004; March 12-16, 2007; and April 5-9, 2010, following KDHE sampling protocols (Kansas Department of Health and Environment, 2000) with minor adjustments to improve consistency among sites. The KDHE protocol is semiquantitative and uses timed sampling from multiple habitat types. Two independent 100-organism samples were collected and counted onsite by two scientists simultaneously for about 1 hour (fig. $3 E$ ) and later pooled into one 200-organism sample. Macroinvertebrates were collected using standard 9 in. $x 18$ in. rectangular-frame kicknets with mesh size approximately $500 \mu \mathrm{m}$ following physical disturbance of the substrate upstream from the net. Habitat types were sampled according to their relative availability and generally included coarse gravel and cobble in riffles, fine gravel and sand/silt substrates near margins or in runs, leaf packs and coarse detritus accumulations, submerged aquatic vegetation and undercut banks, and large moveable objects like logs or rocks. Habitats such as vegetation and large objects were physically disturbed by the collector and then scooped immediately downstream with the net. Streamside sorting trays and forceps were used to sort organisms. Any organism that appeared different in size, shape, or color compared to organisms previously sorted was included in the sample to maximize diversity. Samples were preserved in 80-percent ethanol and shipped to the USGS NWQL for taxonomic identification and enumeration following methods described by Moulton and others (2000).

\section{Data Analysis}

\section{Streamflow Metric Data}

Statistical streamflow metrics (table 2) were calculated and used in correlation analysis along with other environmental variables to better understand factors that affect biological conditions. Streamflow variables used in analyses were obtained from several sources including the USGS Streamstats Web site (Perry and others, 2004), calculations for period of record through 2010 (Dave Wolock, U.S. Geological Survey, written commun., 2011) using techniques described by Stewart and others (2006), and The Nature Conservancy's Indicators of Hydrologic Alteration (IHA) method (Richter and others, 1996). More than 100 different streamflow metrics were calculated and a subset of metrics were selected (table 2) that affected stream ecosystems in different ways, differentiated among sites, and represented minimal redundancy.

\section{Periphyton Data}

More than 200 periphyton community metrics were calculated using the Algal Data Analysis Software (ADAS) developed for the U.S. Geological Survey's National WaterQuality Assessment (NAWQA) program (ADAS, version 2.4.8a released November 30, 2006; T.F. Cuffney, U.S. Geological Survey, written commun., 2009). A subset of about 24 metrics was selected for additional analysis and comparison among sites, and only those metrics are provided

Table 2. Summary of streamflow metrics used in analyses of biological and environmental data for streams in Johnson County, Kansas.

\begin{tabular}{|c|c|c|}
\hline General characteristic & Streamflow metric & $\begin{array}{c}\text { Examples of ecosystem effects (Richter } \\
\text { and others, 1996) }\end{array}$ \\
\hline $\begin{array}{l}\text { Magnitude of monthly streamflow condi- } \\
\text { tions ( } 3 \text { months prior to sampling) }\end{array}$ & $\begin{array}{l}\text { Median monthly streamflow, January } \\
\text { Median monthly streamflow, February } \\
\text { Median monthly streamflow, March }\end{array}$ & $\begin{array}{l}\text { Habitat availability, soil moisture availability, } \\
\text { water temperature, dissolved oxygen. }\end{array}$ \\
\hline $\begin{array}{l}\text { Magnitude and duration of annual stream- } \\
\text { flow conditions }\end{array}$ & $\begin{array}{l}\text { Mean annual streamflow } \\
\text { Base-flow index } \\
\text { Minimum 7-day mean streamflow } \\
\text { Percentiles of daily flow } \\
\text { Minimum daily flow } \\
\text { Maximum daily flow } \\
\text { Standard deviation of daily flow }\end{array}$ & $\begin{array}{l}\text { Shape and form new habitats, create colonizing } \\
\text { sites, flush organic materials into channel, } \\
\text { purge invasive species, disperse seeds, dura- } \\
\text { tion of stressful conditions. }\end{array}$ \\
\hline $\begin{array}{l}\text { Frequency and duration of low/high } \\
\text { streamflow pulses }\end{array}$ & $\begin{array}{l}\text { Low pulse count } \\
\text { High pulse count } \\
\text { Low pulse threshold } \\
\text { High pulse threshold }\end{array}$ & $\begin{array}{l}\text { Shape river channel, pools, and riffles, determine } \\
\text { size of streambed substrate, prevent riparian } \\
\text { vegetation from encroaching into channel, } \\
\text { flush away waste, exchange nutrients. }\end{array}$ \\
\hline
\end{tabular}


in tables contained in this report. Unknown or rare taxa were not deleted and lowest taxonomic levels were used during the ADAS analysis. In addition, only taxa with tolerance values were used in metric calculations, and only diatoms were used for saprobity and trophic metrics. Biovolume, rather than total taxa or cell counts, was used for calculation of periphyton metrics because biovolume is indicative of algal biomass (Lowe and Pan, 1996), and to prevent larger numbers of small taxa (as when using abundance data) from having more effect than smaller numbers of larger taxa. In addition, biovolume was analyzed in a previous report (Rasmussen and others, 2009) so data were comparable. Selected metrics describe oxygen tolerance, saprobity, trophic condition, nitrogen uptake metabolism, and other periphyton attributes; these metrics were used to determine among-site differences (Porter, 2008). The ADAS program uses a common logarithm $\left(\log _{10}\right)$ base to calculate the Shannon Diversity Index. However, previous studies in Johnson County used a natural logarithm base (ln) for calculations. To allow direct comparison among years, ADAS calculated values were converted to a natural logarithm base by multiplying by 2.3026 (Brower and others, 1998). The percentages of total biovolume that are contributed by Nitzschia and Navicula were calculated (Stevenson and Rollins, 2007) to indicate contributions to total periphyton biovolume because Nitzschia are indicative of ecosystem disturbance and Navicula are considered pollution tolerant. Most of the metrics that were used in periphyton analyses were selected because they represent water-quality variables of interest, commonly highlight patterns in data, and are recommended by Stevenson and Rollins (2007), as well as used in USEPA's Rapid Bioassessment Protocols (Barbour and others, 1999).

Nonparametric Wilcoxon signed-rank analysis (Sokal and Rohlf, 1995) was used to test for statistical differences between data sets. Comparisons were made between urban sites and rural sites, and between sites affected by wastewater discharges and sites not affected by wastewater discharges. Each year of data collection included 8-11 urban sites, 8-10 rural sites, and 8-9 sites affected by wastewater discharge. The Wilcoxon analysis tests whether median difference between ranks of paired data values is 0 (the null hypothesis) and the $z$-value represents the test statistic. The probability value ( $p$-value) is the probability that the null hypothesis is correct. Lower $p$-values indicate stronger evidence that the paired data values are significantly different. $P$-values less than 0.05 were considered statistically significant in this report.

\section{Macroinvertebrate Data}

More than 100 macroinvertebrate community metrics were calculated using the Invertebrate Data Analysis System (IDAS) that was developed for the National Water Quality Assessment Program (NAWQA; IDAS, version 5.0.16 released December 10, 2010, Cuffney and Brightbill, 2011). A smaller subset consisting of 11 metrics was selected for additional evaluation, and only those metrics are provided in tables contained in this report (table 3). They include the four KDHE aquatic-life metrics (Kansas Department of Health and Environment, 2010a), plus those used in Poulton and others (2007) and Rasmussen and others (2009) for multimetric site scoring, which made it possible to make comparisons to previous results. The four aquatic-life metrics include EphemeropteraPlecoptera-Trichoptera taxa richness (EPTRich) and Ephemeroptera-Plecoptera-Trichoptera percent abundance (percentage of EPT), which were calculated using IDAS, and Macroinvertebrate Biotic Index (MBI; Davenport and Kelly, 1983) and Kansas Biotic Index (KBI-NO; Huggins and Moffet, 1988) which were calculated as described in these references. The selected metrics represent core metrics used in many State evaluation programs, and those known to be sensitive and reliable for measuring degradation of stream assemblages (table 3 ). The process for selecting the 11 metrics is described in detail by Poulton and others (2007). During analysis using the IDAS program, the lowest taxonomic levels were used, rare or unknown species were not deleted, and taxonomic ambiguities were resolved by retaining ambiguous data. The Shannon Diversity Index was calculated by using natural logarithms as described in Brower and others (1998).

In addition to comparing sites on the basis of individual metrics, multimetric site scores were calculated to compare degree of biological disturbance or relative conditions. The multimetric scores integrated 10 equally weighted metrics that measure various community facets, including diversity, composition, tolerance, and feeding characteristics, and were calculated using the same methods described in Poulton and others (2007) and also used by Rasmussen and others (2009). Multimetric scores were determined by proportionally scaling each of the 10 metrics among sites, thus transforming each value to numbers between 1 and 100 with 1 representing the poorest biological quality and 100 representing optimum biological quality. The 10 proportionally scaled metrics for each site were summed to determine the multimetric score. The 10-metric scores were used to represent a relative measure of stream-quality condition on the basis of macroinvertebrate communities and to indicate a continuum of biological response to overall human-induced disturbances among the study sites as described by the Biological Condition Gradient conceptual model (Davies and Jackson, 2006). Humaninduced disturbances include any physical and chemical stressors that might directly or indirectly affect stream condition. For each of the two sites where replicate macroinvertebrate samples were collected, each of the metrics was calculated by averaging values from the three replicate samples. Multimetric scores were calculated by using the replication mean.

Multimetric scores also were used to compare relative biological effects from human disturbance (least affected, moderately affected, and most affected) as indicated by the 10-metric macroinvertebrate scores and a general knowledge of environmental conditions and sources of human disturbance at the sites. Groups were determined by ranking the sites according to 10-metric scores, and evaluating statistical differences between groups to find logical boundaries for placing sites together that have similar biological conditions (Poulton 
Table 3. List of macroinvertebrate metrics, abbreviations, and references used for assessment of biological conditions at monitoring sites in Johnson County, Kansas, 2010.

[KDHE metrics are those used for evaluating the condition of aquatic life in Kansas streams (Kansas Department of Health and Environment, 2010a); KBI-NO, Kansas Biotic Index; X, metric included; --, metric not included; \%, percentage; $<$, less than]

\begin{tabular}{|c|c|c|c|}
\hline Metric name and reference (if available) & Abbreviation & KDHE metrics & Multimetric score \\
\hline Macroinvertebrate Biotic Index (Davenport and Kelly, 1983) & MBI & $\mathrm{X}$ & $\mathrm{X}$ \\
\hline Kansas Biotic Index (KBI) (Huggins and Moffett, 1988) & KBI-NO & $\mathrm{X}$ & $\mathrm{X}$ \\
\hline $\begin{array}{l}\text { Ephemeroptera-Plecoptera-Trichoptera (EPT) taxa richness (Klemm and } \\
\text { others, 1990) }\end{array}$ & EPTRich & $\mathrm{X}$ & $\mathrm{X}$ \\
\hline Total taxa richness (Barbour and others, 1999) & TRich & -- & $\mathrm{X}$ \\
\hline EPT abundance (Barbour and others, 1999) & $\%$ EPT & $\mathrm{X}$ & -- \\
\hline Percentage of Scrapers (Barbour and others, 1999) & $\% \mathrm{Sc}$ & -- & $\mathrm{X}$ \\
\hline Percentage of Oligochaeta (Lenat, 1993; Kerans and Karr, 1994) & $\%$ Olig & -- & $\mathrm{X}$ \\
\hline Percentage of Tanytarsini midges (DeShon, 1995) & \% Tany & -- & $\mathrm{X}$ \\
\hline Percentage of intolerant organisms $(\mathrm{KBI}<3)$, (Huggins and Moffett, 1988) & $\%$ Int-KBI & -- & $\mathrm{X}$ \\
\hline Percentage of Ephemeroptera and Plecoptera & $\% \mathrm{EP}$ & -- & $\mathrm{X}$ \\
\hline Shannon Diversity Index (Washington, 1984) & SDI & -- & $X$ \\
\hline
\end{tabular}

and others, 2007). Classification results were compared among sites and years of data collection.

The State of Kansas uses four macroinvertebrate metrics, MBI, KBI-NO, EPTRich, and percentage of EPT, for establishing the ability of a stream to support aquatic life and for placement of sites into impairment categories (Kansas Department of Health and Environment, 2010b). Mussel community loss, a fifth State metric of aquatic invertebrate health, is also used if the site is known to have supported at least five mussel species. This metric was not calculated in this report because five mussel species were not found at most sites during previous studies, probably because watersheds were too small to provide suitable habitat. To determine aquatic-life status and relative degree of impairment, these four metric scores were combined into an overall site score representing the mean across all of the metrics included.

Nonparametric Wilcoxon signed-rank analysis (Sokal and Rohlf, 1995) was used to test for statistical differences between data sets, and $p$-values less than 0.05 were considered statistically significant.

\section{Relating Biological Data to Environmental Variables}

Nonparametric statistical analyses were used to determine relations between macroinvertebrate and periphyton communities, water and streambed-sediment quality, habitat measurements, macroinvertebrate and periphyton communities, and watershed variables including land use and streamflow variables. SAS (ver. 9.2) software (Delwiche and Slaughter, 1998) was used to test Spearman rank correlations for monotonic associations between data. Spearman rank-correlation coefficients (rho values) were considered significant when $p$-values were less than 0.01 and highly significant when $p$-values were less than 0.001. LOWESS (LOcally WEighted Scatterplot Smoothing; Helsel and Hirsch, 2002) was used to represent general biological response patterns to urbanization. The PRIMER (ver. 6) software (Clarke and Ainsworth, 1993; Clarke and Warwick, 2005; Clarke and Gorley, 2006), which applies nonparametric statistical analyses, was used to evaluate variable similarities and for multidimensional scaling (MDS). The PRIMER software uses nonparametric and permutation approaches to reduce the complexities of multivariate ecological data (many species, metrics, and environmental variables) and graphically displays relations between biological communities, sampling sites, and environmental variables (Clarke and Warwick, 2005). The BEST feature in PRIMER was used to determine the most important environmental variables for explaining biological conditions. BEST uses ranks correlation to determine environmental variables that produce a resemblance matrix similar to the macroinvertebrate matrix (Clarke and Warwick, 2005). Correlations and multivariate analyses were used to characterize relations between variables but do not establish direct causal relations.

Ordinary least squares (OLS) regression analysis was used to develop relations between biological indicator metrics (response variables) and environmental variables (explanatory variables) (Helsel and Hirsch, 2002). A smaller set of potentially suitable explanatory variables was selected after examining scatter plots for linearity of data distribution and meaningful explanatory relations, and Spearman rank correlation coefficients for redundancy among explanatory variables. The selected explanatory variables, which included about 20 descriptors of land use, streamflow, water and streambedsediment chemistry, in-stream habitat, and riparian buffer conditions, were used in regression model development. Regression models included data from one sample at each site in 2007 and 2010. Variables were transformed when necessary to 
improve distribution and reduce the risk of violating assumptions of OLS regression. Models were only considered useful when all regression coefficients were statistically significant at $p$-values less than 0.05 . Models then were evaluated using diagnostic statistics $\left(\mathrm{R}^{2}\right.$, coefficient of determination; RMSE, root mean squared error) and patterns in residual plots.

\section{Quality Assurance and Quality Control}

\section{Water and Streambed-Sediment Data}

Replicate water and streambed-sediment samples were collected at two different sites in each year of sampling. Relative percent difference (RPD) was used to evaluate differences in analyte concentrations detected in replicate water samples. RPD is calculated as $\{|\mathrm{A}-\mathrm{B}| /[(\mathrm{A}+\mathrm{B}) / 2]\} \times 100$, where $\mathrm{A}$ and $\mathrm{B}$ are concentrations in each replicate pair. Most of the quality assurance and quality control information was published in previous reports (Lee and others, 2005; Poulton and others, 2007; Rasmussen and others, 2009). Generally, the RPD between replicate water samples was less than 10 percent with the exception of some nutrients with RPDs ranging to as much as 20 percent, and occasionally larger RPDs when concentrations were near the laboratory reporting level. Replicate pairs of detectable concentrations of nutrients, trace elements, and organic compounds in streambed-sediment samples also had RPDs less than about 10 percent with the exception that the RPD for nitrogen species ranged to as much as 20 percent.

\section{Periphyton Data}

Two field-replicate samples for chlorophyll concentration and periphyton community composition, abundance, and biovolume analyses were collected at two sites each year. Coefficient of variation (CV; Sokal and Rohlf, 1995) was used to make comparisons. Concurrent field-replicate sample CVs for periphyton chlorophyll, abundance, and biovolume ranged from 5 percent to 60 percent. High CVs are likely because of the natural variability in periphytic communities (Stevenson, 1997) and the effect of rare taxa that were not present in all samples.

\section{Macroinvertebrate Data}

Replicate macroinvertebrate samples were collected at one rural and one urban site each year. Metrics were calculated for each sample individually and were compared using CV values. The mean annual $\mathrm{CV}$ across monitoring sites for replicate metric values was less than 20 percent except for percentage of scrapers, percentage of Oligochaeta, and percentage of Tanytarsini midges, for which the $\mathrm{CV}$ ranged from about 30 percent to 100 percent. These metric evaluations were strongly affected by rare taxa that occurred in some replicates but not others. Additionally, variability likely was affected by habitat differences among the sampling locations within each stream reach.

Quality assurance and quality control for macroinvertebrate identification, enumeration, and data entry procedures generally followed those outlined in Moulton and others (2000) and included within-laboratory cross-checking of individual samples and specimens. Current taxonomic keys and voucher specimens are kept on file at the USGS NWQL in Lakewood, Colorado. Other quality-assurance efforts included repeated identification and enumeration procedures by different laboratory technicians and a full comparison of bench sheets for a minimum of 10 percent of the samples.

\section{Assessment of Stream Quality}

\section{Environmental Variables}

Environmental variables that affect stream quality include watershed variables such as land use (table 1), precipitation, and streamflow, as well as stream-water chemistry, streambed-sediment chemistry, and riparian and in-stream habitat conditions.

\section{Watershed Variables}

Precipitation and resulting streamflow conditions can have short-term and long-term effects on biological communities and year-to-year variability can confound data interpretation. The study design calls for samples to be collected in early spring during base flow, that is, allowing adequate time following precipitation such that the stream conditions sampled were not affected by recent runoff. However, during both 2007 and 2010, short periods of recent runoff may have affected biological communities at some sites. Rainfall during the first 3 months of 2010 was about normal compared to those months in previous years (fig. 4). But weather patterns with frequent light-to-moderate rainfall during the spring of 2010 prevented optimal sampling conditions, resulting in a sampling delay of about 2 weeks past the optimal collection period. Although samples were collected during below-normal streamflow, some sites in 2010 were affected by rainfall that occurred in the days and weeks prior to collection. Several sites received $0.5-0.75 \mathrm{in}$. of rainfall within a few days before sampling.

Regarding precipitation and streamflow conditions during and before sample collections, the year 2003 was the driest year (fig. 4) and streamflow was notably lower during sample collection that year compared to all of the subsequent years (fig. 5). The following year, 2004, had the most total rainfall of the years sampled during March; however, samples were collected in late February and early March 2004 and thus were not affected by the highest streamflow peaks in early March (fig. 5). In 2007, four increasingly larger streamflow pulses occurred at most monitoring sites during the 4 weeks before sample collection, but samples were not collected until about 

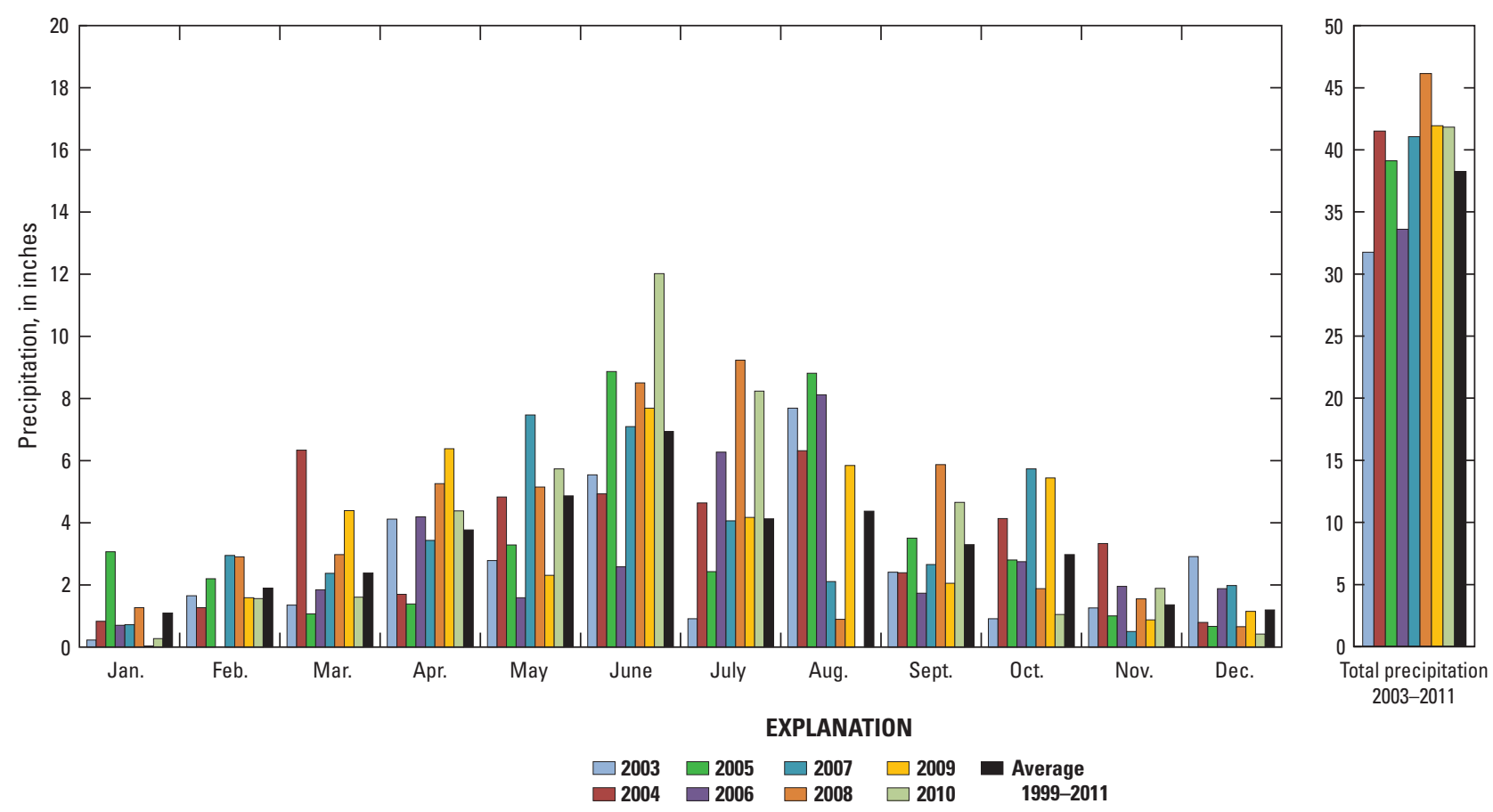

Figure 4. Monthly and annual precipitation in Olathe, Kansas, 2003-10.

1 week after the last peak (fig. 5). In 2010, biological communities may have been affected by rainfall at Indian Creek at State Line Road (IN6), Mill Creek at Johnson Drive (MI7), and possibly other sites where samples may have been collected immediately following a rise in streamflow without adequate time for biological communities to recover (fig. 5). All of the medium and larger runoff events seen in figure 5 likely were large enough to result in entrainment of substrate particles and turbidity values higher than $100 \mathrm{FNU}$ (formazin turbidity units).

Statistical streamflow metrics, used as variables in correlation analysis, were calculated for seven monitoring sites where streamflow data were available (table 4). Twenty streamflow metrics were selected that affected stream ecosystems in different ways, differentiated among sites, and represented minimal redundancy.

\section{Stream-Water Chemistry}

Stream-water chemistry is described on the basis of discrete water samples collected during base flow for all years studied and at about the same time biological samples were collected in 2007 and 2010. Base flow water-chemistry data provide some information about water quality at the sites but do not fully describe water quality that likely affects biological communities in the days, weeks, or months prior to sampling. Data qualified by the laboratory as estimated (E) indicates reported values were outside instrument calibration range, analysis did not meet acceptable method-specific criteria, or matrix interference occurred. The precision of estimated values is frequently less than the precision of values reported without this qualifier (Childress and others, 1999). Waterquality constituents not detected at any sites are excluded from tables of results.

Specific conductance is a measure of dissolved ions in stream water and is determined primarily by rock and soil types and weathering rates, the amount of groundwater contributing to streamflow, the amount of urbanization and agriculture, and quality and quantity of discharges from wastewater and industrial sites (Hem, 1992). Road-salt application for de-icing purposes is also a source of dissolved solids, particularly chloride, sodium, and magnesium. Elevated roadsalt concentrations in streams have been known to cause acute and chronic toxicity to aquatic organisms (Corsi and others, 2010), and elevated concentrations have been known to persist throughout summer months (Ostendorf and others, 2001). Continuous water-quality monitoring in Johnson County streams indicated that chloride concentrations in urban streams are greater than rural streams year-round and often exceed the EPA recommended chronic freshwater quality criterion of 230 milligrams per liter (mg/L) (U.S. Environmental Protection Agency, 2012) during snowmelt and winter runoff conditions as a result of road-salt application (Rasmussen and others, 2008).

Specific conductance, dissolved solids, and major ions varied largely from site to site. The range in specific conductance is an indication of base-flow variability in dissolved solids and major ions among sites (fig. 6). Specific conductance ranged from 316 microsiemens per centimeter $(\mu \mathrm{s} / \mathrm{cm})$ at the Captain Creek site (CA1) in 2010 to more than 1,500 $\mu \mathrm{s} /$ $\mathrm{cm}$ at two Little Mill sites (LM1a and LM1b) and the Turkey Creek (TU1) site in 2007 (appendix 3). Generally, specific 
Figure 5. Daily streamflow conditions 3 months before biological sampling in Johnson County, Kansas, and approximate period of sample collection, 2003, 2004, 2007, and 2010.

conductance was highest at urban sites, with the exception of the rural site Cedar Creek at Old Highway 56 (CE1). Although the Cedar Creek site is classified as rural with one-fourth of the drainage area urban land, a large area of commercial and industrial land, including a limestone quarry, is located less than 1 mile upstream from the site on both sides of Cedar Creek. Elevated specific conductance was measured in 2002, 2003, and 2010 at site CE1 and corresponded to high concentrations of dissolved solids ( $805-1,070 \mathrm{mg} / \mathrm{L}$ ), sodium (100-150 mg/L), sulfate (307-414 mg/L), and magnesium (24-33 mg/L). The highest specific conductance occurred in 2007 at 18 of the 20 sites with data in 2007 (not sites BI1 or CE1). Higher countywide specific conductance in 2007 likely is related to generally lower precipitation (fig. 4) and more groundwater contribution to base flow. The Big Bull site (BI1) likely had higher specific conductance in 2002 and 2003 because of upstream wastewater discharge that was discontinued in 2007. Chloride concentrations exceeded the chronic criterion of $230 \mathrm{mg} / \mathrm{L}$ in 2007 at each of the 3 Little Mill Creek sites (ranging from 253-347 mg/L), and at the Turkey Creek site (TU1, $330 \mathrm{mg} / \mathrm{L}$, appendix 3). Although the winter of 2006-07 received about one-half of the normal snowfall (10.2 in. compared to the annual average of $19.9 \mathrm{in}$.; National Oceanic and Atmospheric Administration, 2011), freezing precipitation events in January and February 2007 may have resulted in higher use of snowmelt products during the 2-3 months before sampling in 2007.

The highest base-flow nutrient concentrations in water occurred directly downstream from WWTFs. Total nitrogen (calculated by summing nitrate, nitrite, ammonia, and organic nitrogen) and total phosphorus were highest, for each year sampled, at Indian Creek sites IN3a and IN6, which are directly downstream from WWTFs, and at the first Mill Creek site downstream from a WWTF (MI4, table 1, appendix 3, fig. 6). Total nitrogen and total phosphorus at the two Indian Creek sites (IN3a and IN6) demonstrated a pattern of substantial concentrations in the first sample collected followed by sequentially decreasing concentrations in subsequent samples. Reductions in total nitrogen and total phosphorus at the two Indian Creek sites can be attributed to lower contributions 
Table 4. Streamflow statistics used in correlation analysis for biological monitoring sites in Johnson County, Kansas, 2002-10.

$\left[\mathrm{mi}^{2}\right.$, square miles; $\mathrm{ft}^{3} / \mathrm{s}$, cubic feet per second; $\left(\mathrm{ft}^{3} / \mathrm{s}\right) / \mathrm{mi}^{2}$, cubic feet per second per square mile; $\left(\mathrm{ft}^{3} / \mathrm{s}\right) / \mathrm{d}$, cubic feet per second per day]

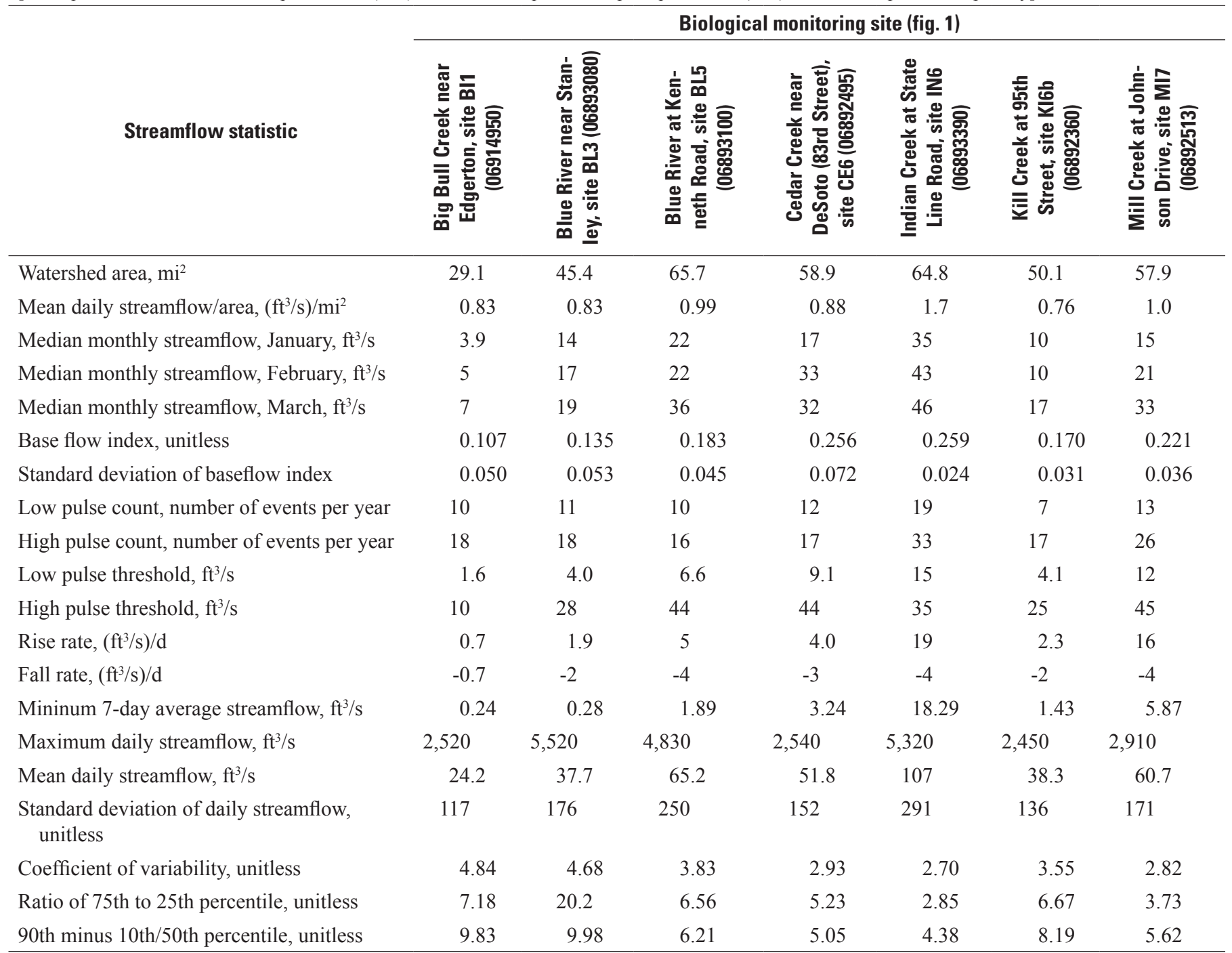

from the dissolved species, nitrate and orthophosphorus, likely originating from wastewater discharge. Total nitrogen and total phosphorus at the Mill Creek site (MI4) decreased from 2003 onward (fig. 6). Although there were no notable changes in total nitrogen concentrations from 2002 to 2010 at the downstream Cedar Creek site (CE6) or the upstream Kill Creek site (KI5b), both sites had among the highest total phosphorus concentrations in 2002 (0.77 and $0.72 \mathrm{mg} / \mathrm{L}$, respectively), which decreased each year until 2010 when it was 0.14 and $0.17 \mathrm{mg} / \mathrm{L}$, respectively (appendix 3).

Suspended-sediment concentrations ranged from less than $10 \mathrm{mg} / \mathrm{L}$ in about one-third of the samples collected (2002-10) to more than $200 \mathrm{mg} / \mathrm{L}$ in one sample each from Little Bull Creek in 2003 and Turkey Creek in 2010. Generally, sites downstream from wastewater discharges have been determined to have lower suspended-sediment concentrations during base flow than others sites because of the higher clarity of treated wastewater (Lee and others, 2005). The highest suspended-sediment concentrations at 10 of the sites (50 percent) occurred in 2010 and at 5 sites ( 25 percent) in 2007. This is likely because the amount of recent rainfall before sample collection was greater during those years. Variability in suspended-sediment concentration among sites and years (including the Little Bull site, LI1, during 2010 with concentrations about triple that of any other site, fig. 6D) in this study can be attributed primarily to runoff before sample collection.

Base flow densities of Escherichia coli (E.coli) bacteria, commonly used as an indicator of pathogens in surface water, ranged from less than 10 colonies per 100 milliliters of water $(\mathrm{col} / 100 \mathrm{~mL})$ at the rural Blue River site in 2003 to 4,400 col/100 mL at the rural Captain Creek site in 2010 (appendix 3). Generally, E. coli densities were highly variable among both urban and rural sites and among sampling years. 

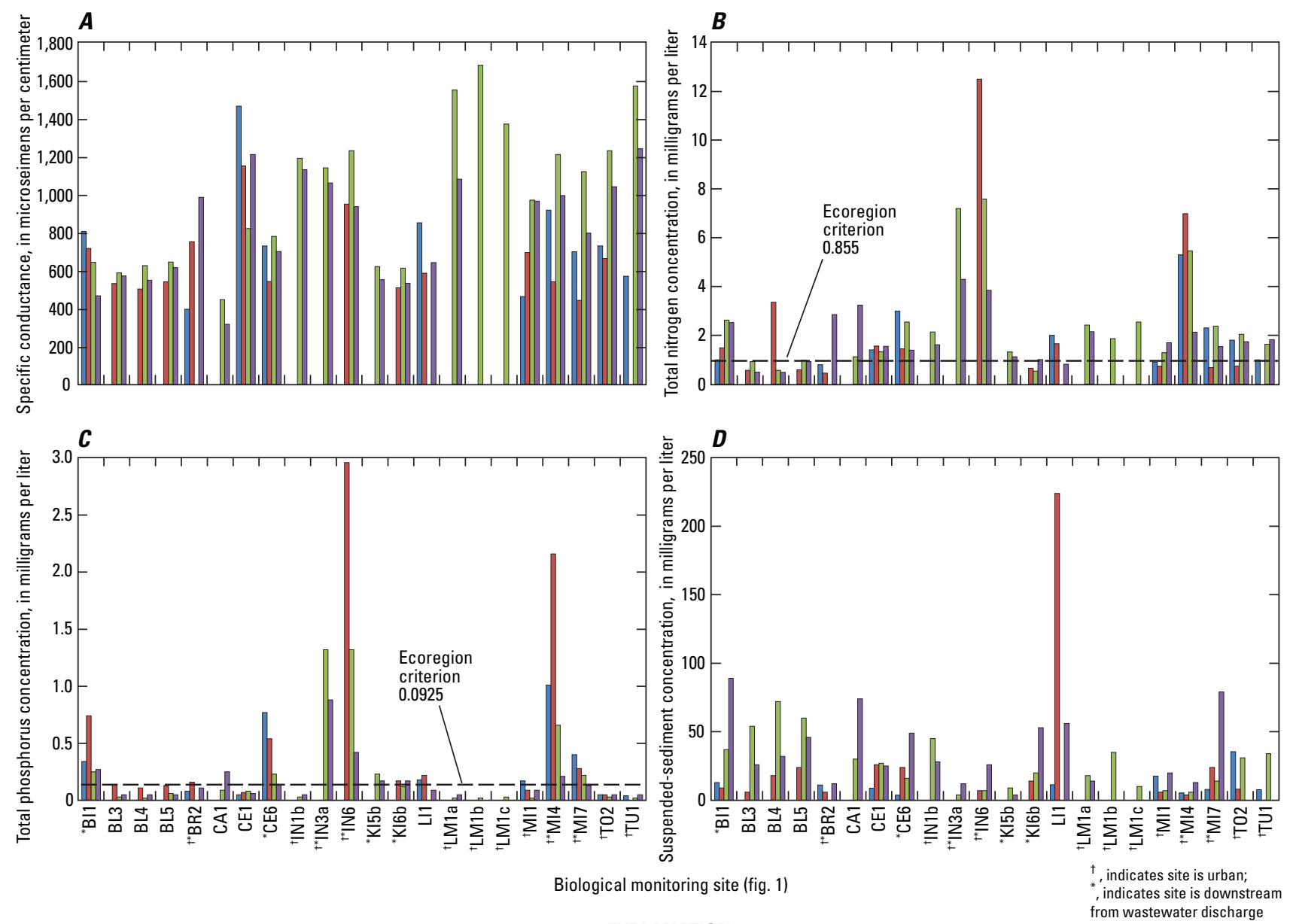

EXPLANATION $\square 2002 \square 2007$
$\square 2003 \square 2010$

Figure 6. Selected water-quality characteristics during base flow sampling at monitoring sites in Johnson County, Kansas, 2002, 2003, 2007, and 2010.

\section{Streambed-Sediment Chemistry}

Because many compounds are hydrophobic, concentrations of many contaminants in streambed sediment are much greater than concentrations dissolved in the above water column (Horowitz, 1991). Streambed-sediment chemistry is described on the basis of streambed-sediment samples collected during base-flow conditions during years sampled, and at about the same time biological samples were collected in 2007 and 2010. Data were qualified by the laboratory with estimated or left-censored (less-than) values as described by Childress and others (1999). Streambed-sediment constituents that were not detected at any site are not included in tables. Organic compounds in streambed-sediment samples collected in 2003 and 2007 were analyzed from unsieved, bulk samples rather than from sieved samples (fraction finer than 63 microns). Because most compounds are sorbed preferentially to the fine fraction, concentrations in 2003 and 2007 likely are biased low in comparison to concentrations in samples collected in 2010.
The highest concentrations of carbon and nutrients in streambed sediment occurred in 2003 at most sites, followed by concentrations in 2010 (appendix 4, fig. 7). Most sites had increases in total organic carbon from 2007 to 2010, but the net change from 2003 to 2010 was a median decrease in total organic carbon of 23 percent at all except four sites (BL3, IN6, TO2, TU1). Organic carbon affects biogeochemical processes in aquatic systems and in streambed sediment increases adsorption of metals (Horowitz, 1991) and organic compounds (Karickhoff, 1984). However, linear associations between total organic carbon and other constituents analyzed in streambed sediment were apparent only for total nitrogen and total phosphorus (selected scatter plots are shown in appendix 5). Precipitation, and consequently streamflow, was lowest in 2003 compared to the following years (fig. 4), which likely contributed to higher nutrient concentrations downstream from WWTFs. High total organic carbon and nutrient concentrations at the Big Bull Creek site (BI1) in 2003 decreased to at least one-fourth of those concentrations in 2007 and 2010 (fig. 7, appendix 4), likely because of the reduction in 

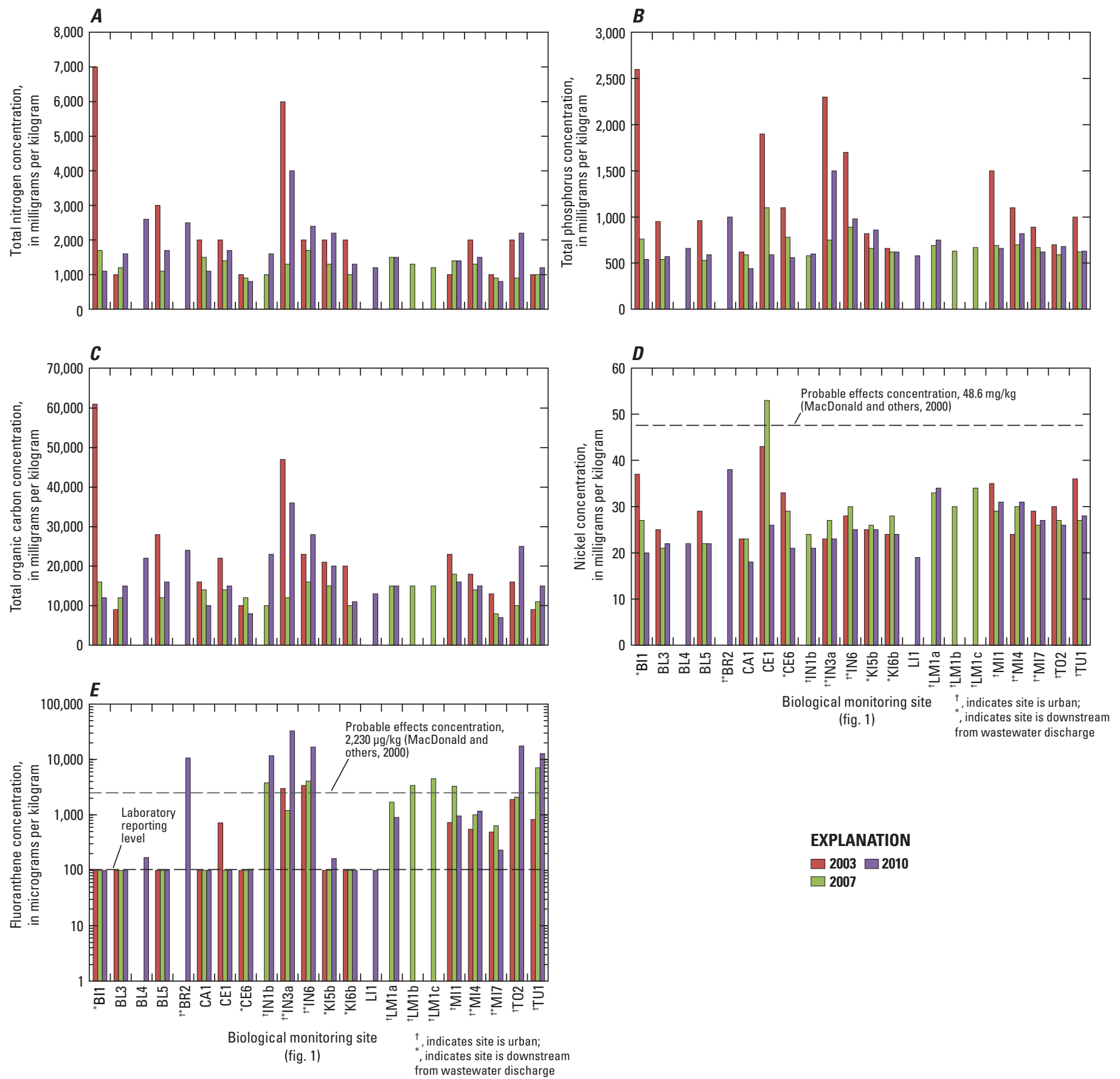

EXPLANATION

$\square 2003 \square 2010$

$\square 2007$

Figure 7. Concentrations of selected sediment-quality constituents in streambed samples collected during base-flow at monitoring sites in Johnson County, Kansas, 2003, 2007, and 2010.

upstream wastewater discharge contributions. The city of Gardner's wastewater treatment facility, which had a design flow of 1 million gallons per day (mgd), closed during 2007 and flows subsequently are being pumped to a treatment facility in the Kill Creek watershed. Nutrient concentrations in sediment downstream from the Kill Creek WWTF (KI5b) were slightly higher in 2010 than in previous years (fig. 7). Increases in concentrations at the Kill Creek site would not be expected to be proportional to decreases in concentrations at the Big Bull Creek site because of differences in wastewater treatment processes, receiving stream conditions, and distance of monitoring sites from wastewater discharge sites. During 2010, the highest nutrient concentrations (nitrogen and phosphorus) in sediment occurred at the Indian Creek site directly downstream from Douglas L. Smith WWTF (IN3a, fig. 1).

Trace metals were detected in streambed sediment from all sites. Probable effects concentrations (PECs) have been developed for some trace metals and are shown in appendix 4 (MacDonald and others, 2000; U.S. Environmental Protection Agency, 1998). The PEC represents the concentration 
of a contaminant in streambed sediment that is expected to adversely affect benthic biota. The highest concentrations of trace metals in 2010 occurred at sites on Mill and Indian Creeks (appendix 4). Sites in the Mill Creek watershed had among the highest 2010 aluminum (ranging from 61,000 to $64,000 \mathrm{mg} / \mathrm{kg}$ ), chromium (60 to $68 \mathrm{mg} / \mathrm{kg}$ ), and iron $(26,000$ to $34,000 \mathrm{mg} / \mathrm{kg}$ ) concentrations. The highest concentrations of zinc occurred at two sites with heavy bridge traffic (IN6 and IN1b). Some metal concentrations showed downward trends across the county from 2003 to 2010 . For example, nickel concentrations decreased by at least 20 percent at 6 of the 15 sites for which data were available in 2003, and increased at 1 site (MI4, fig. 7, appendix 4). Zinc concentrations decreased by at least 20 percent at 9 of the 15 sites. However, zinc concentration at Indian Creek at State Line (IN6) increased from $170 \mathrm{mg} / \mathrm{kg}$ in 2003 to $500 \mathrm{mg} / \mathrm{kg}$ in 2010 , exceeding the PEC of $459 \mathrm{mg} / \mathrm{kg}$. Zinc was the only metal to exceed the PEC in 2010. Chromium and nickel at the upstream Cedar Creek site (CE1) exceeded PECs in 2007, and no metals exceeded PECs in 2003. At the Big Bull Creek site (BI1) about 70 percent of the detected constituents in 2003 decreased by at least 20 percent in 2010. Concentrations of trace elements in streambed sediment during the study period were within the range of concentrations reported in a national pilot study of streambed-sediment contaminants in metropolitan streams (Moran and others, 2011).

Of 72 organic compounds analyzed in streambed sediment (appendix 1), 26 were detected (appendix 4) including pesticides, polycyclic aromatic hydrocarbons (PAHs), fuel products, fragrances, preservatives, plasticizers, manufacturing byproducts, flame retardants, and disinfectants. All six PAH compounds analyzed (anthracene, benzo[a]pyrene, fluoranthene, naphthalene, phenanthrene, and pyrene) were detected. PAHs originate from the incomplete combustion of fossil fuels and are common in diesel fuel, crude oil, and gasoline. A frequent source of PAHs in urban areas is coal-tar sealcoats that are applied to parking lots (Mahler and others, 2005). Effects of PAHs on benthic macroinvertebrates include inhibited reproduction, delayed emergence, and higher mortality rates, and effects on fish include fin erosion, liver abnormalities, cataracts, and immune system impairments (U.S. Environmental Protection Agency, 2008). PECs for 4 of the 6 PAH compounds analyzed were exceeded in 2010, in some instances by as much as 14 times (fluoranthene at site IN3a and phenanthrene at site IN1b). Concentrations of PAH compounds commonly exceeded PECs at the most urban sites, Brush Creek (BR2), Indian Creek (IN1b, IN3a, and IN6), Tomahawk Creek (TO2), and Turkey Creek (TU1). For example, fluoranthene was detected at all urban sites each year it was analyzed (fig. 7), but was rarely detected at rural sites. Fluoranthene concentrations exceeded the PEC at 2 of the urban sites in 2003, 6 of them in 2007, and 6 of them in 2010. Higher PAH concentrations in 2010 may have resulted from more recent deposition from stormwater runoff immediately preceding sample collection. Concentrations of PAH compounds during the study period were within the range of concentrations reported in a national pilot study of streambed-sediment contaminants in metropolitan streams (Moran and others, 2011).

Among the organic compounds analyzed in streambed sediment were 26 pesticides, 16 of which were pyrethroid compounds. Only five pesticide compounds analyzed in sediment were detected, including carbazole and four pyrethroid compounds. Carbazole, which also occurs in dyes, lubricants, and explosives, was detected at six sites, all urban, in 2010 (appendix 4). At least one pyrethroid compound was detected at 6 sites, including 3 urban sites and 3 rural sites. Of the 8 detections of pyrethroid compounds at the 6 sites, chronic toxicity guidelines were exceeded at 5 sites (bifenthrin at sites LM1a, MI4, and TU1; cyfluthrin at site BR2; permethrin at site CE6). In a national study of pyrethroid occurrence, bifenthrin, cyfluthrin, and permethrin were detected in 58 percent, 14 percent, and 31 percent of samples, respectively (Hladik and others, 2012).

\section{Riparian and In-Stream Habitat Conditions}

Differences in total habitat scores were negligible between 2007 (Rasmussen and others, 2009) and 2010, and only 2010 values are shown in tables and figures. Total habitat scores from 2010 were suboptimal at 17 of the 20 monitoring sites and marginal at the remaining sites (fig. 8, table 5). Variability in total habitat scores was minimal among sites, likely because stream types within the small geographic study area are generally similar. The lowest habitat scores (corresponding with the poorest habitat conditions) occurred at the three most urbanized sites, Brush Creek (BR2), downstream Indian Creek (IN6), and Turkey Creek (TU1). Those sites generally scored lower on most of the individual habitat variables, but also scored particularly low for vegetated buffer length and width. Buffer width is a measure of natural vegetation (including forest, shrubs, and native grasses) extending from the stream bank out into the riparian zone. A wide buffer helps control erosion, promotes nutrient uptake, can produce shading and habitat structure in the channel (if woody species are present), and allows runoff more time to percolate into soils before entering the stream (Barbour and others, 1999). Longitudinal buffer status considers the continuity of the buffer, which is often interrupted by bridge crossings and stormwater drains in urban areas. Additionally, bank stability was highest at two of those sites (BR2 and TU1, fig. 8) because of artificial bankerosion control features.

The downstream Blue River site (BL5) and the Kill Creek sites (KI5b; KI6b) had the highest total habitat scores (indicating better habitat conditions), followed by the Big Bull site (BI1) and the other two Blue River sites (BL3 and BL4). Land use upstream of all of those sites is primarily rural. These sites generally scored well on in-stream habitat variables related to sediment deposition and habitat diversity 

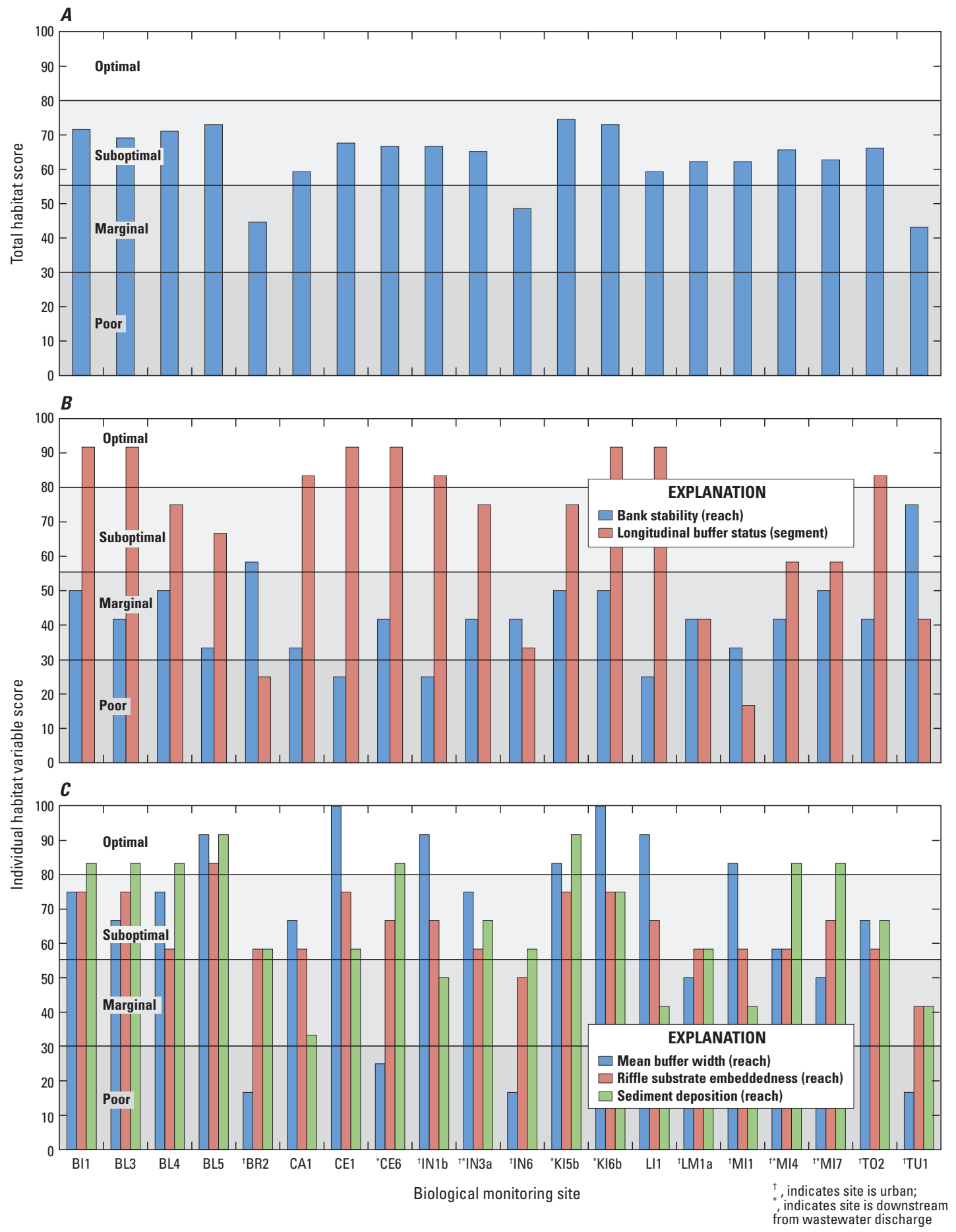

Figure 8. Total habitat score and scores for selected individual habitat variables at biological monitoring sites in Johnson County, Kansas, 2010.

(fig. 8). Excessive sediment deposition makes the streambed unsuitable for many organisms and can lead to substrate embeddedness, which further reduces living space available to macroinvertebrates and fish. Substrate diversity provides cover, protection from high current velocity, feeding sites, and spawning sites in the form of woody debris, leaf packs, root mats, and inundated vegetation.

\section{Biological Variables}

Biological variables included in the evaluation of stream quality were periphyton and macroinvertebrate communities. Statistical analyses and emphasis in discussion for this report is on 2010 results with some comparisons to previously collected data, which are described in more detail by Poulton and others (2007) and Rasmussen and others (2009). Differences 


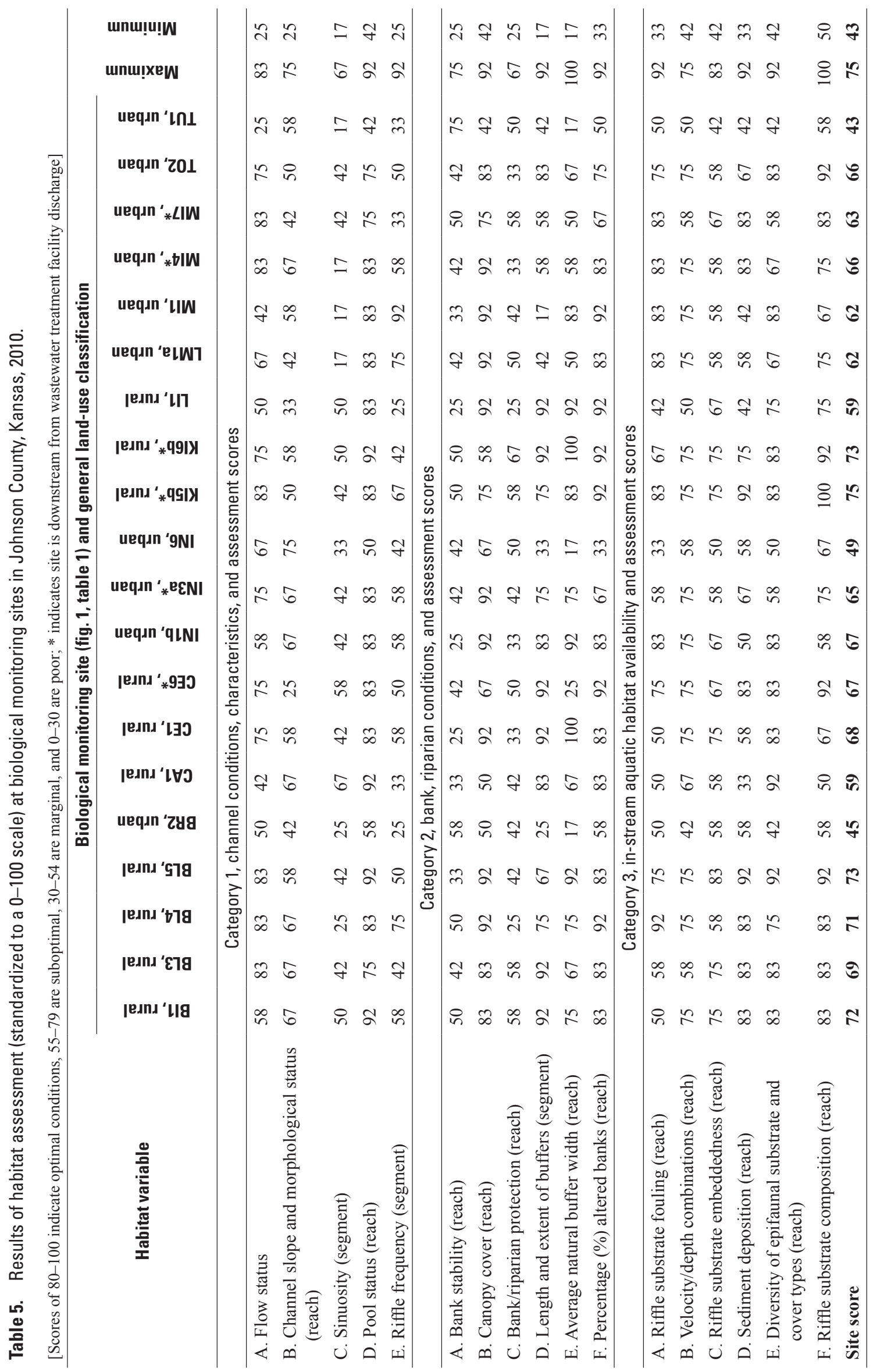


between datasets were considered significant ( $p$-value less than 0.05 ) according to Wilcoxon signed-rank analysis (Sokal and Rohlf, 1995).

\section{Algal Periphyton Communities}

Periphyton are the attached algae that grow on submerged stream surfaces, such as rocks and woody debris. Periphyton are primary producers and are a key link between abiotic factors, such as sunlight and nutrients, and higher trophic levels, such as macroinvertebrates and fish. Periphytic communities commonly are used as indicators of ecological conditions because they respond rapidly to changes in environmental conditions. As such, physical, chemical, and pollution tolerances and optimal growth conditions have been described for many periphytic algal species (Porter, 2008). Although algal assemblages increasingly are being used as indicators of environmental condition (U.S. Environmental Protection Agency, 2002), the State of Kansas currently (2012) does not use periphyton in biological assessments of water quality. Several States, including Kentucky (Kentucky Division of Water, 1993), Montana (Bahls, 1993), and Oklahoma (Oklahoma Conservation Commission, 1993) use periphyton in their bioassessment programs.

\section{Community Composition}

Overall, 129 periphyton taxa were identified from the 20 sites sampled in Johnson County in 2010 (appendix 6), which is about 40 percent greater than the number of taxa identified in 2007 (Rasmussen and others, 2009). This difference likely is because almost twice as many stream sites were sampled in 2010 compared to 2007. Similar to 2007, during 2010 most taxa (109) were in the division Bacillariophyta (diatoms). Eight taxa were in the division Chlorophyta (green algae), six taxa were in the division Cyanophyta (cyanobacteria or blue-green algae), four taxa were in the division Euglenophyta (euglenoids), and one taxon was in the divisions Rhodophyta (red algae) and Streptophyta (green plants). About 80 percent of the periphyton taxa were relatively rare (observed at only 1 or 2 sites, or contributing less than 1 percent to total periphyton abundance or biovolume, or both), which was a large increase compared to about one-half of the taxa classified as rare in 2007. Based on taxa occurrence, among the most common periphyton taxa in 2010 were the diatoms Amphora pediculus, Cocconeis placentula, Gomphonema olivaceum, and Navicula cryptotenella. These taxa generally are indicative of eutrophic conditions (Porter, 2008). Diverse communities with abundance or biovolume, or both dominated by few taxa commonly occur in Johnson County streams and streams throughout the Nation (Bahls, 1973; Brown and Olive, 1995; Kutka and Richards, 1996; Rasmussen and others, 2009; Graham and others, 2010).

Periphyton abundance and biovolume at all sites were dominated (greater than 75 percent of total) by diatoms (Bacillariophyta) during 2007 (Rasmussen and others, 2009) and 2010 (appendix 6), with the exception of biovolume at the Tomahawk Creek site (TO2) in 2007. Green algae (Chlorophyta) occurred at 9 out of the 20 sites and contributed from less than 1 percent to 22 percent of total abundance and biovolume. Blue-green algae (Cyanophyta) occurred at seven sites with total abundance and biovolume that ranged from less than 1 to 15 percent. Cyanobacteria generally are considered a nuisance when present because of their potential to produce toxins and disagreeable taste and odor compounds (Graham and others, 2008). Green algae and cyanobacteria blooms in streams are most likely to occur in summer when temperatures are warmer and flows are usually at seasonal lows (Allan, 1995). Cyanobacteria dominance typically indicates enrichment by nutrients and organic pollution (Stevenson and Rollins, 2007).

\section{Periphyton Chlorophyll Concentrations, Abundance, and Biovolume}

Chlorophyll is the green pigment that allows photosynthesis to occur and can be used as an indirect measure of algal biomass. Chlorophyll often is used to describe algal communities because it is less time consuming than counting, identifying, and measuring algal cells. Periphyton abundance is the total number of cells present, whereas chlorophyll concentrations and biovolume are indicators of periphyton biomass. Nuisance conditions have been defined for periphyton chlorophyll but not for abundance and biovolume.

Total chlorophyll concentrations in 2010 ranged from 3.2 to 250 milligrams per square meter $\left(\mathrm{mg} / \mathrm{m}^{2}\right.$; table 6 , fig. 9). Nuisance algal conditions have been documented to occur when periphytic chlorophyll concentrations exceed $100 \mathrm{mg} / \mathrm{m}^{2}$ (Horner and others, 1983; Welch and others, 1988). Six of the 20 sites exceeded this chlorophyll threshold value in 2010, and 4 of 11 sites exceeded the threshold in 2007. With the exception of site TO2 in 2010 and IN6 in 2007, which are both urban, the sites that exceeded the chlorophyll threshold value were rural. Total chlorophyll in 2010 was significantly higher ( $z$-value 2.42, $p$-value 0.01 ) at rural sites (median $95 \mathrm{mg} / \mathrm{m}^{2}$ ) than at urban sites (median $37 \mathrm{mg} / \mathrm{m}^{2}$ ).

Algal periphyton abundance in 2010 ranged from 0.11 billion cells per meter square (billion cells $/ \mathrm{m}^{2}$ ) to 18 billion cells $/ \mathrm{m}^{2}$ (table 6 , fig. 9). Periphyton abundance during 2010 was not significantly different for urban sites compared to rural sites, or for sites affected by wastewater compared to sites not affected by wastewater. Periphyton biovolume ranged from 30 cubic millimeters per meter square $\left(\mathrm{mm}^{3} / \mathrm{m}^{2}\right)$ to $16,000 \mathrm{~mm}^{3} / \mathrm{m}^{2}$ during 2010 (table 6). The upper range in 2010 was about one-half of the largest biovolume in 2007 (MI7, 32,000 mm $/ \mathrm{m}^{2}$ ). Periphyton biovolume in 2010 was significantly larger ( $z$-value $2.2, p$-value 0.01$)$ at rural sites (median $3,100 \mathrm{~mm}^{3} / \mathrm{m}^{2}$ ) than at urban sites (median $860 \mathrm{~mm}^{3} / \mathrm{m}^{2}$ ). Larger periphyton biovolume at rural sites was not caused by higher nutrient concentrations since urban sites generally had higher nutrient concentrations than rural sites. It may have been caused by lower light conditions at urban 
Table 6. Algal periphyton chlorophyll concentrations, abundance, and biovolume at biological monitoring sites in Johnson County, Kansas, March and July 2007, and April 2010.

$\left[\mathrm{mg} / \mathrm{m}^{2}\right.$, milligrams per square meter; $\mathrm{mm}^{3} / \mathrm{m}^{2}$, cubic millimeters per square meter; ${ }^{*}$, site is downstream from wastewater treatment facility discharge $]$

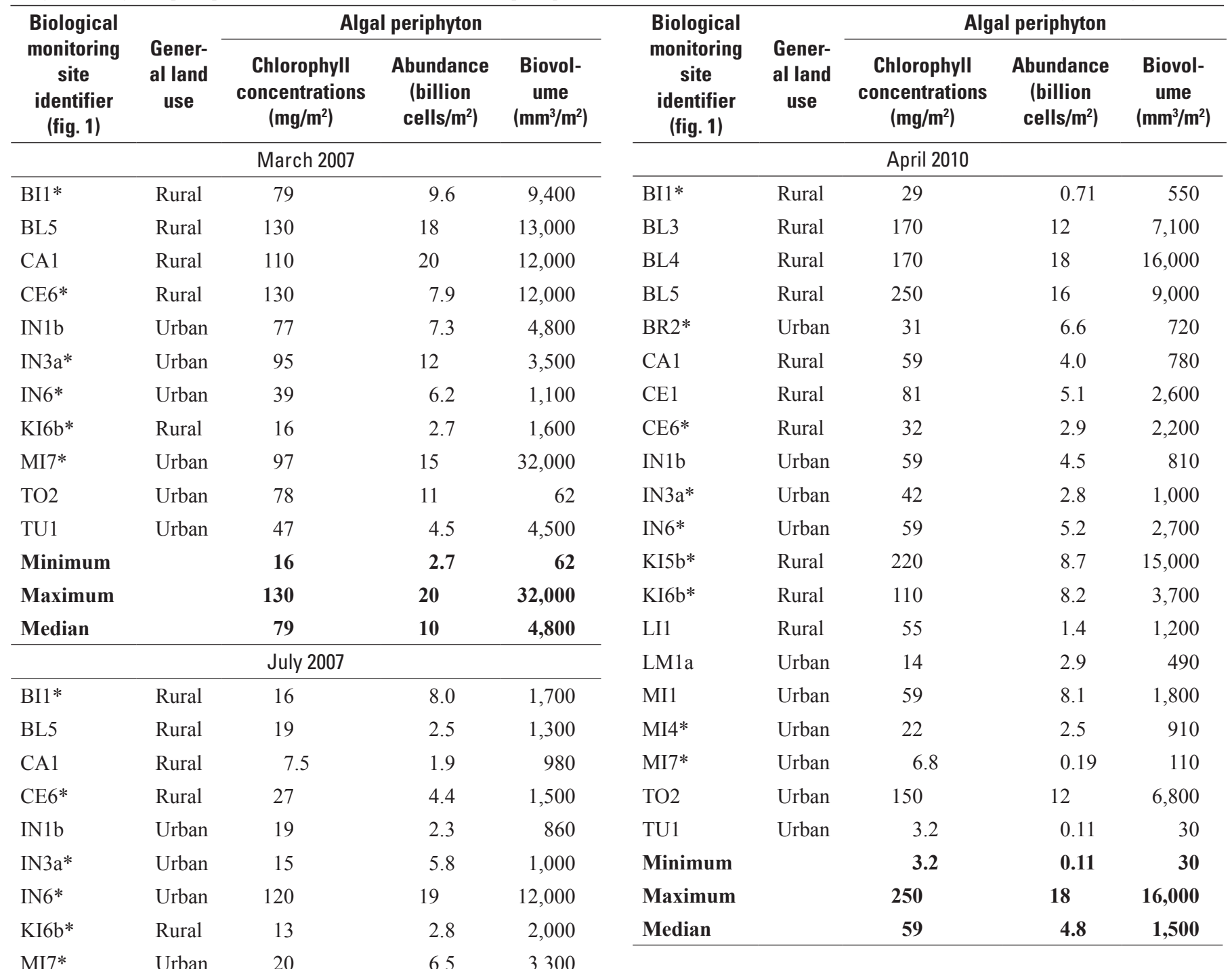

TO2 Urban 25

$2.7 \quad 1,800$

TU1 Urban 16

Minimum 7.5

Maximum

120

19

Nitzschia linearis. All of the most common taxa generally were indicative of eutrophic conditions (Porter, 2008).

\section{Periphyton Metrics}

Physical, chemical, and pollution tolerances and optimal growth conditions have been described for many species of periphyton, which makes it possible to use these indices as indicators of ecological condition. Periphyton communities in 2010 were evaluated using 24 metrics in 4 categories including oxygen tolerance, saprobity, trophic condition, and nitrogen uptake metabolism, in addition to 3 other common metrics (table 7). The metrics are indicative of a range of conditions from good to poor and provide a basis for evaluating potential stressors on algae communities. Differences among stream sites and between 2007 and 2010 also were evaluated on the basis of percent contribution of diatom indicator taxa to total periphyton biovolume (table 8). 

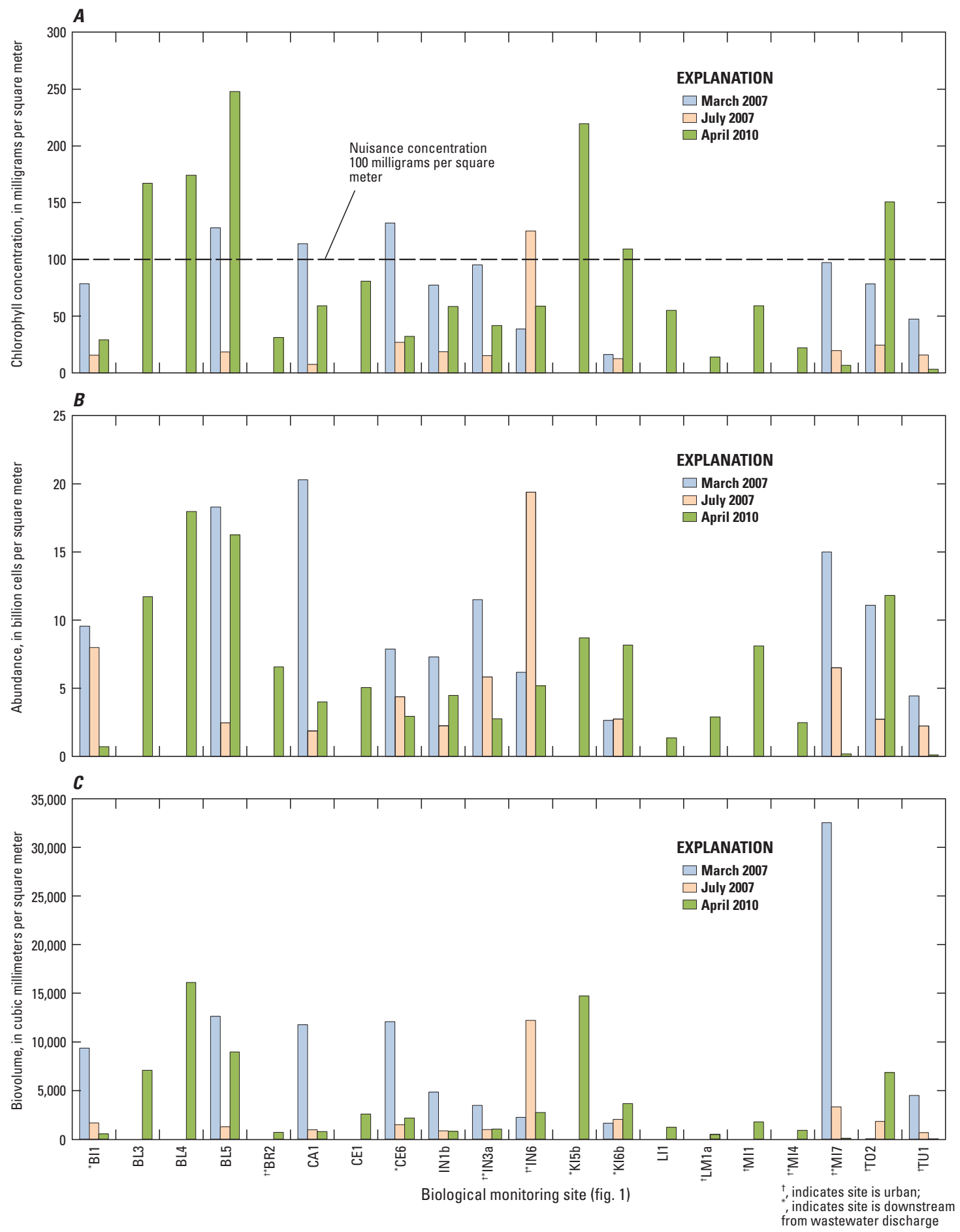

Figure 9. Algal periphyton chlorophyll concentrations, abundance, and biovolume at biological monitoring sites in Johnson County, Kansas, 2007 and 2010.

\section{Oxygen Tolerance}

Oxygen tolerance describes the oxygen conditions where organisms often occur, and is expressed using the percentage of diatoms in one or more of five oxygen tolerance categories: very low (less than 10 percent oxygen saturation), low (greater than 30 percent oxygen saturation), moderate (greater than 50 percent oxygen saturation), fairly high (greater than
75 percent oxygen saturation), and always high (near 100 percent oxygen saturation; Cuffney, 2003; Porter, 2008). The percentage of diatoms in the low and moderate categories was summed as discussed as a single oxygen-tolerance metric in this section. Percentage of diatoms that tolerate low and moderate oxygen conditions ranged from 5.7 at the rural Kill Creek site (KI5b) to 52.6 at the urban Mill Creek site (M17), 


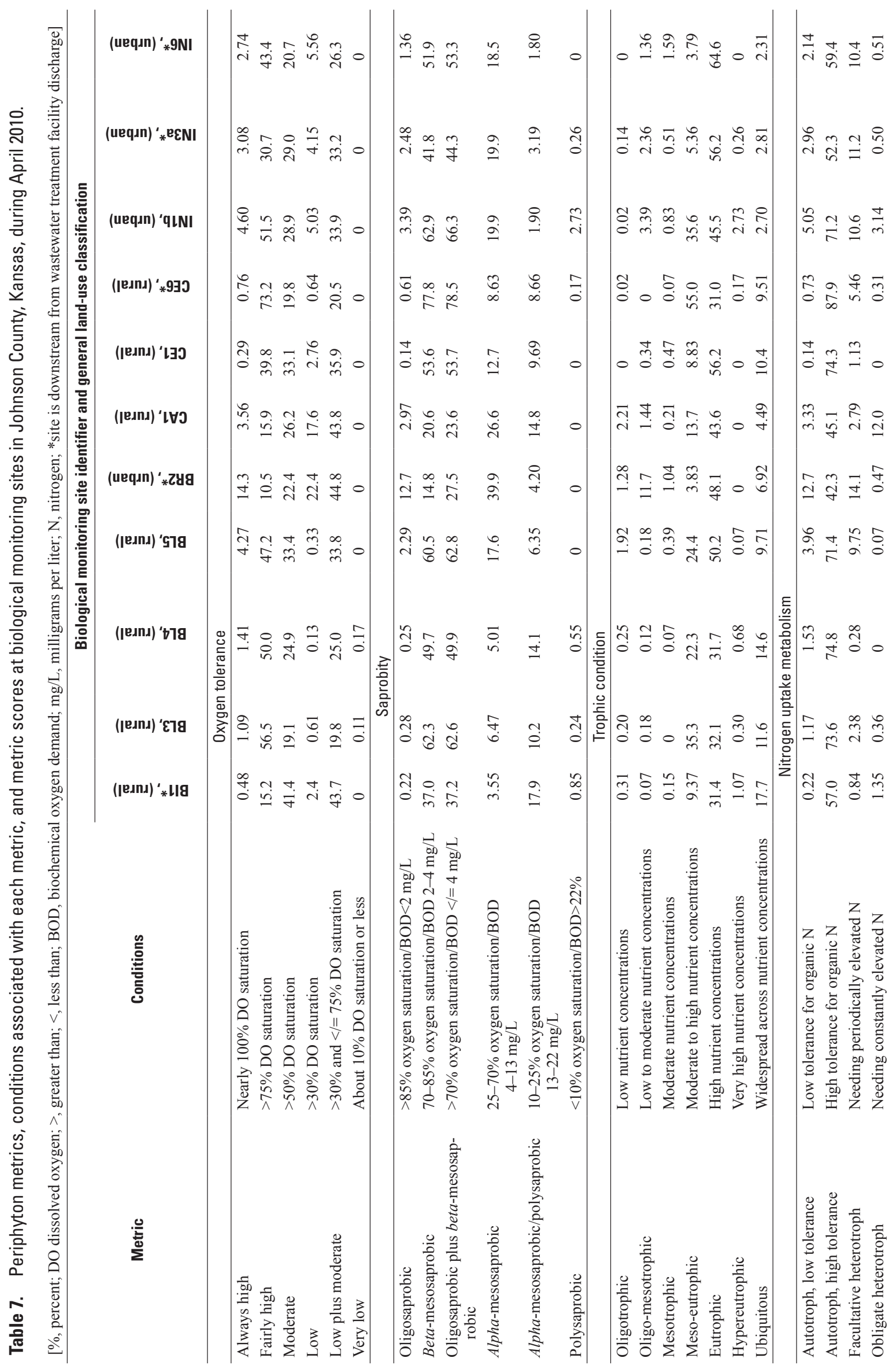




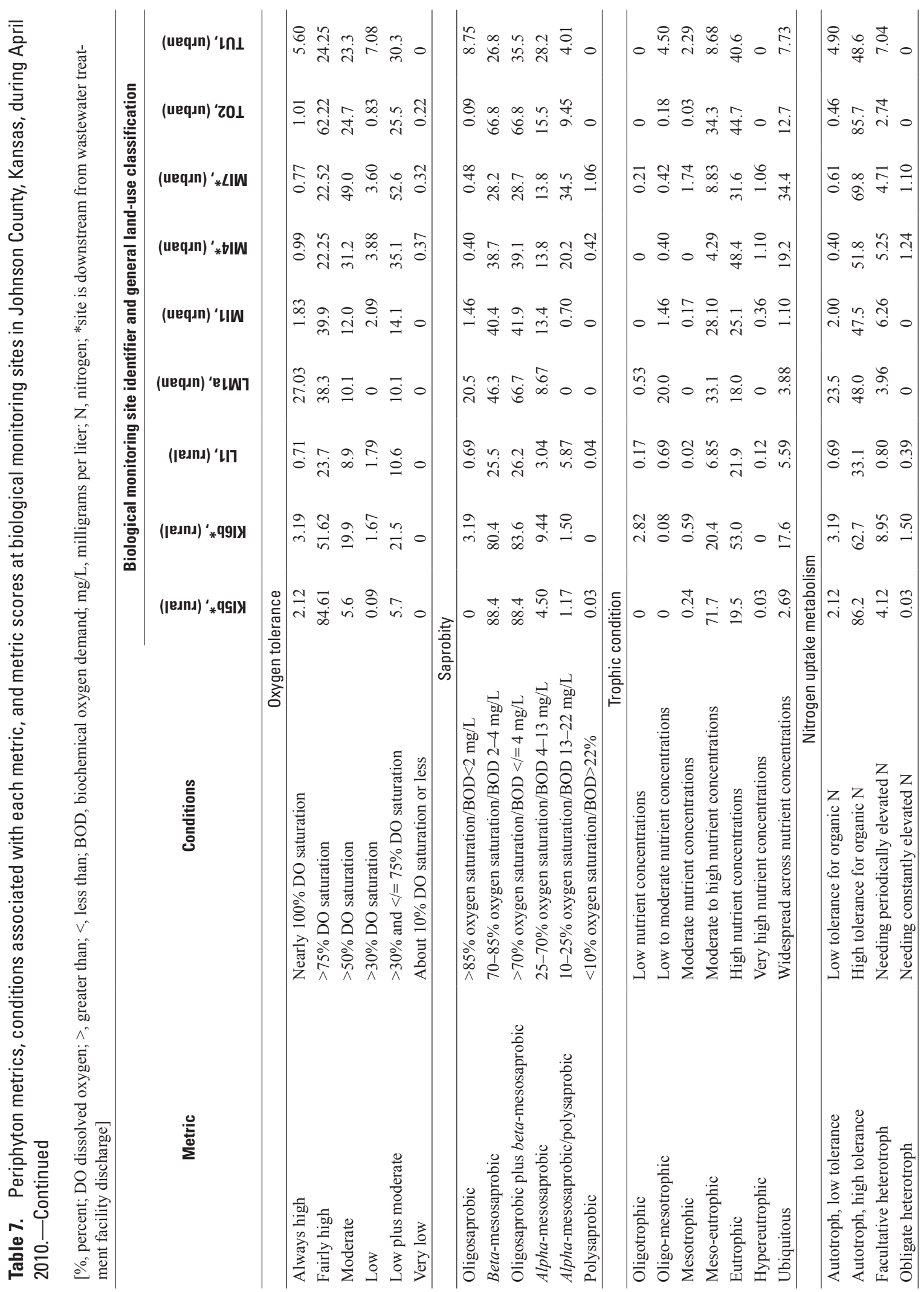


Table 8. Percentage contribution of diatom indicator taxa or groups of diatom indicator taxa to total periphyton biovolume at biological monitoring sites in Johnson County, Kansas, March and July 2007, and April 2010.

[Eutraphenic (high nutrient) taxa, sum of Amphora, Cocconeis, Diatoma, Gyrosigma, Meridion, Nitzchia, and Synedra biovolume; Motile taxa, sum of Gyrosigma, Navicula, Nitzchia, and Sururella biovolume; Low nutrient taxa, sum of Achnanthes, Cymbella, and Encyonema biovolume; *, site is downstream from wastewater treatment facility discharge]

\begin{tabular}{|c|c|c|c|c|c|c|}
\hline \multirow[b]{2}{*}{$\begin{array}{l}\text { Biological } \\
\text { monitoring } \\
\text { site identi- } \\
\text { fier (fig. 1) }\end{array}$} & \multirow[b]{2}{*}{$\begin{array}{c}\text { Gener- } \\
\text { al land } \\
\text { use }\end{array}$} & \multicolumn{5}{|c|}{ Percentage contributions to total biovolume } \\
\hline & & 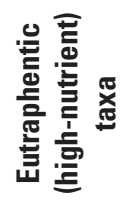 & 䒿 & 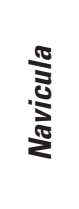 & 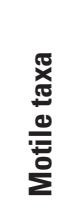 & 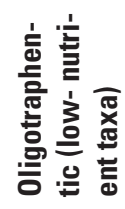 \\
\hline \multicolumn{7}{|c|}{ March 2007} \\
\hline BI1* & Rural & 35 & 6.7 & 3.2 & 31 & 0.4 \\
\hline BL5 & Rural & 43 & 17 & 6.4 & 36 & 0 \\
\hline CA1 & Rural & 8.8 & 5.1 & 28 & 44 & 0 \\
\hline CE6* & Rural & 71 & 3.4 & 3.9 & 13 & 0 \\
\hline IN1b & Urban & 29 & 22 & 1.1 & 45 & 0 \\
\hline IN3a* & Urban & 35 & 13 & 10 & 36 & 15 \\
\hline IN6* & Urban & 40 & 28 & 23 & 28 & 0.4 \\
\hline KI6b* & Rural & 36 & 9.5 & 12 & 32 & 0.3 \\
\hline MI7* & Urban & 65 & 4.2 & 1.4 & 15 & 0 \\
\hline TO2 & Urban & 25 & 1.5 & 0.5 & 4.1 & 0 \\
\hline TU1 & Urban & 4.1 & 4.1 & 1.4 & 76 & 0.1 \\
\hline Minimum & & 4.1 & 1.5 & 0.5 & 4.1 & $\mathbf{0}$ \\
\hline Maximum & & 71 & 28 & 28 & 76 & 15 \\
\hline Median & & 35 & 7 & 4 & 32 & $\mathbf{0}$ \\
\hline \multicolumn{7}{|c|}{ July 2007} \\
\hline BI1* & Rural & 18 & 15 & 28 & 28 & 0.3 \\
\hline BL5 & Rural & 49 & 1.3 & 15 & 17 & 1 \\
\hline CA1 & Rural & 46 & 2.7 & 21 & 22 & 0.1 \\
\hline CE6* & Rural & 37 & 13 & 36 & 37 & 9.1 \\
\hline IN1b & Urban & 55 & 4.6 & 19 & 19 & 1.1 \\
\hline IN3a* & Urban & 27 & 8.7 & 27 & 27 & 6.2 \\
\hline IN6* & Urban & 20 & 2.2 & 2.6 & 2.6 & 0.4 \\
\hline KI6b* & Rural & 25 & 10 & 19 & 23 & 34 \\
\hline MI7* & Urban & 19 & 5.8 & 30 & 31 & 0.3 \\
\hline TO2 & Urban & 18 & 4.3 & 18 & 27 & 0.7 \\
\hline TU1 & Urban & 25 & 23 & 62 & 62 & 0 \\
\hline Minimum & & 18 & 1.3 & 2.6 & 2.6 & $\mathbf{0}$ \\
\hline Maximum & & 55 & 23 & 62 & 62 & 34 \\
\hline Median & & 25 & 6 & 21 & 27 & 1 \\
\hline
\end{tabular}

with a median of 28 percent (table 7). No significant difference occurred between urban and rural site groups, or between wastewater-affected and nonwastewater-affected site groups.

\section{Saprobity}

Saprobes are organisms that derive nourishment from nonliving or decaying organic material. The saprobic index combines organism tolerance to the presence of biodegradable

\begin{tabular}{|c|c|c|c|c|c|c|}
\hline \multirow[b]{2}{*}{$\begin{array}{l}\text { Biological } \\
\text { monitoring } \\
\text { site identi- } \\
\text { fier (fig. 1) }\end{array}$} & \multirow[b]{2}{*}{$\begin{array}{l}\text { Gener- } \\
\text { al land } \\
\text { use }\end{array}$} & & & & & \\
\hline & & 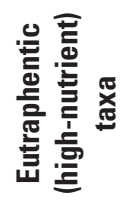 & : & 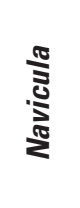 & 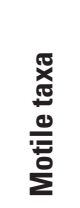 & 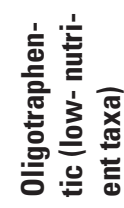 \\
\hline \multicolumn{7}{|c|}{ April 2010} \\
\hline BI1* & Rural & 31 & 11 & 3.7 & 44 & 0.3 \\
\hline BL3 & Rural & 32 & 20 & 23 & 28 & 0.2 \\
\hline BL4 & Rural & 50 & 27 & 36 & 32 & 0.8 \\
\hline BL5 & Rural & 50 & 13 & 23 & 22 & 1.9 \\
\hline $\mathrm{BR} 2 *$ & Urban & 48 & 16 & 27 & 58 & 1.3 \\
\hline CA1 & Rural & 44 & 13 & 47 & 68 & 2.2 \\
\hline CE1 & Rural & 56 & 21 & 6.7 & 45 & 0 \\
\hline CE6* & Rural & 31 & 3.8 & 21 & 8.5 & 0 \\
\hline IN1b & Urban & 46 & 47 & 6.6 & 63 & 0 \\
\hline IN3a* & Urban & 56 & 17 & 16 & 54 & 0.1 \\
\hline IN6** & Urban & 65 & 11 & 16 & 45 & 0 \\
\hline KI5b* & Rural & 19 & 5.7 & 11 & 8.2 & 0 \\
\hline KI6b* & Rural & 53 & 4.1 & 46 & 30 & 2.8 \\
\hline LI1 & Rural & 22 & 23 & 4.1 & 85 & 0.2 \\
\hline LM1a & Urban & 18 & 37 & 2.0 & 58 & 0.5 \\
\hline MI1 & Urban & 25 & 34 & 4.8 & 77 & 0 \\
\hline MI4* & Urban & 48 & 31 & 4.9 & 59 & 0 \\
\hline MI7* & Urban & 32 & 20 & 19 & 40 & 0.2 \\
\hline TO2 & Urban & 45 & 39 & 4.3 & 29 & 0 \\
\hline TU1 & Urban & 41 & 20 & 21 & 57 & 0 \\
\hline Minimum & & 18 & 3.8 & 2.0 & 8.2 & 0 \\
\hline Maximum & & 65 & 47 & 47 & 85 & 2.8 \\
\hline Median & & 44 & 20 & 16 & 45 & $\mathbf{0}$ \\
\hline
\end{tabular}

organic matter and hypoxic conditions, and was developed to evaluate the sensitivity of diatom communities to organic pollution (Kolkwitz and Marsson, 1908; Van Dam and others, 1994). ADAS uses five saprobity categories representing a gradient of conditions ranging from relatively pristine (oligosaprobic) to highly polluted (polysaprobic): oligosaprobic, beta-mesosaprobic, alpha-mesosaprobic, alpha-mesosaprobic/ polysaprobic, and polysaprobic. These categories represent a gradient of conditions ranging from relatively pristine, with higher oxygen concentrations and lower biodegradable organic matter concentrations (oligosaprobic) to highly polluted with lower oxygen and higher organic matter concentrations (polysaprobic, Van Dam and others, 1994; Porter, 2008). The saprobix index was calculated for this section as the summed percentages of diatoms in the oligosaprobic and 
beta-mesosaprobic categories, which combined are indicative of relatively unpolluted conditions. Percent oligosaprobic and beta-mesosaprobic diatoms had a median of 54 and ranged from 23.6 percent at the rural Captain Creek site (CA1) to 88.4 percent at the rural Kill Creek site (KI5b, table 7). No significant difference occurred between urban and rural site groups, or between wastewater-affected and non-wastewateraffected site groups.

\section{Trophic Condition Taxa}

Trophic condition is indicative of ecosystem productivity with respect to nutrient concentrations. Oligotrophic systems have low nutrient concentrations and productivity, mesotrophic systems have moderate nutrient concentrations and productivity, and eutrophic systems have high nutrient concentrations and productivity (Graham and others, 2008). ADAS classifies diatoms into seven trophic categories. Diatom communities are indicative of moderate and high nutrient concentrations at all of the monitoring sites (table 7) with no discernible patterns in urban and rural land use, indicating nutrients are available for algae growth in streams throughout the study area.

\section{Nitrogen Uptake Metabolism}

Nitrogen uptake metabolism refers to the source of nitrogen required by periphyton or diatoms for growth. High tolerance autotrophs, which require inorganic nitrogen sources such as nitrate or ammonia for growth, comprised the highest percentage of diatoms at all sites, ranging from 33.1 percent at the Little Bull site (LI1) to 87.9 percent at the lower Cedar Creek site (CE6, table 7).

\section{Diatom Indicator to Total Periphyton Biovolume}

Eutraphentic (high nutrient) diatoms prefer nutrientenriched and eutrophic conditions (Stevenson and Rollins, 2007). Eutraphentic diatoms comprised 18 to 65 percent of total periphyton biovolume in spring (April) 2010 (table 8) compared to the larger range of 4.1 to 71 percent that occurred in spring (March) 2007 (Rasmussen and others, 2009). Site IN6 had the fourth highest percent eutraphentic diatoms in spring 2007 (after sites CE6, MI7, and BL5), and the highest percent eutraphentic diatoms in spring 2010. Oligotraphentic (low nutrient) taxa comprised less than 3 percent of periphyton biovolume at all sites in 2010 (table 8), indicating nutrientenriched conditions occur in both urban and rural streams.

Species of Nitzchia typically are considered to be pollution tolerant and species of Navicula typically are considered to be indicators of ecosystem disturbance (Stevenson and Rollins, 2007). The largest range for Nitzchia as a percentage of total biovolume (3.8 to 47 percent) occurred in 2010 (table 8 ) when site IN1b (urban, not affected by wastewater) had the highest percent of Nitzchia to total biovolume. In 2010, urban sites (median 25 percent) had a significantly higher ( $z$-value 2.3, $p$-value 0.01$)$ Nitzchia percentage contribution than rural sites (median 31 percent), and sites not affected by wastewater (median 23 percent) had significantly higher (z-value 2.6, $p$-value 0.004) Nitzchia percentage than sites affected by wastewater (median 11 percent). Percentage of Navicula to total biovolume ranged from 2.0 to 47 in 2010 (table 8). Sites CA1 and KI6b (both rural) had Navicula percentages that were higher than 45 percent in 2010. The highest percent Navicula of both years (62 percent) occurred at site TU1 (urban, not affected by wastewater) during July 2007.

Motile taxa are indicative of sedimentation because they have the ability to survive by moving to the sediment surface if they become covered by silt (Barbour and others, 1999). The percent of motile taxa biovolume to total biovolume ranged from 8.2 to 85 percent in 2010 (table 8). Site TU1 during 2007 and sites CA1, IN1b, LI1, and MI1 during 2010, all sites not affected by wastewater but inclusive of both urban and rural sites, had the highest motile taxa score (higher than 60 percent). In 2010, percent motile taxa at urban sites (median 57 percent) was significantly higher ( $z$-value 1.8 , $p$-value 0.03 ) than rural sites (median 31 percent). Percent motile taxa was not significantly different at sites affected by wastewater (median 44 percent) compared to sites not affected by wastewater (median 57 percent). Among sites that were affected by wastewater, urban sites (median 51 percent) had a significantly higher ( $z$-value $2.2, p$-value 0.01$)$ percent contribution of motile taxa than rural sites (median 23 percent).

\section{Macroinvertebrate Communities}

Aquatic macroinvertebrates are the most often recommended and most widely used indicator organisms for biological assessment (Carter and others, 2007) because they are sensitive to environmental change, have short life cycles, and can integrate the effects of changing environmental conditions. Macroinvertebrate communities commonly are used for assessing biological conditions, long-term monitoring, diagnosis of specific environmental problems, quantification of the success of restoration activities, and development of biological criteria in support of water-quality compliance and regulation (Rosenberg and Resh, 1993).

\section{Community Composition}

A total of 181 macroinvertebrate taxa were collected at the Johnson County biological monitoring sites in 2010 (appendix 9), compared to 160 taxa collected in 2007 (Rasmussen and others, 2009). Most taxa were insects (Insecta) in 2010, and about 20 percent were non-insects, mostly mollusks (Bivalvia and Gastropoda), worms (Turbellaria, Enopla, Nematoda, Nematomorpha, and Oligochaeta), leeches (Hirudinea), and crustaceans (Malacostraca). About 22 percent of the insect taxa were in EPT taxa, the three orders of insects typically associated with healthy stream communities (Ephemeroptera, mayflies; Plecoptera, stoneflies; and Trichoptera, caddisflies; referred to as EPT taxa) compared to about 25 percent EPT taxa in 2007 (Rasmussen and others, 2009). In addition to EPT 
taxa, other aquatic insects including dragonflies and damselflies (Odonata), beetles (Coleoptera), midges (Chironomidae), and true bugs (Hemiptera) were common. Overall, the four most common taxa generally are moderately tolerant or tolerant and were Orthocladiinae midges, the chironomid Polypedilum sp., the blackfly Simulium sp., and the Naididae family of oligochaetes.

Generally, most rural stream sites contained a larger diversity of macroinvertebrates including insect orders normally associated with healthier communities. More urban sites had none or few of these insects and were dominated by pollution-tolerant insects. This is consistent with a national study of metropolitan areas that found that urban development typically leads to a decline in pollution sensitive species and a shift to species that are more pollution tolerant (Brown and others, 2009).

\section{Macroinvertebrate Metrics}

Selected macroinvertebrate metrics (table 9) provide the foundation for the assessment of stream biological conditions. Data collected during 2010 are used to describe current conditions and to evaluate changing conditions by making comparisons to data collected during 2003 and 2004 (Wilkison and others, 2006; Poulton and others, 2007), and 2007 (Rasmussen and others, 2009). Individual metrics are described first starting with the four KDHE aquatic-life status metrics and followed by seven others presented in the order they are listed in table 9. Aquatic-life impairment categories are described, and sites are evaluated and compared on the basis of combined 10-metric scores.

\section{Macroinvertebrate Biotic Index (MBI)}

The MBI (Davenport and Kelly, 1983) is a family-level index that is used to evaluate the effects of oxygen-demanding nutrients and organic enrichment on macroinvertebrate communities. Taxa used to calculate the MBI have unitless tolerance values ranging from 1.5 to 11 for some insect and mollusk taxa. Lower tolerance values indicate less tolerance to oxygen-demanding nutrients and organic enrichment and a lesser degree of stream degradation; and higher tolerance values indicate greater tolerance and a higher degree of stream degradation. In 2010, MBI values ranged from 4.60 at Captain Creek (site CA1), a State reference stream, to 7.25 at Turkey Creek (site TU1, table 9). Urban sites (median 6.23) had MBI scores that were significantly greater ( $z$-value $3.87, p$-value less than 0.0001) than those for rural sites (median 5.07). For MBI, none of the sites met the KDHE criteria for full support of aquatic life for MBI (less than 4.51, table 9), and none of the urban sites were classified as even partially supporting aquatic life (MBI less than 5.39). Captain Creek (CA1, in 2003) was the only site that attained the "fully supporting" criterion for MBI during the study period. The Mill Creek TMDL for biological impairment established a MBI goal of 4.5 or less as an average for 2006-2015 (Kansas Department of Health and Environment, 2006); however, MBI values for monitoring sites in the Mill Creek watershed have, thus far, failed to achieve the goal. MBI scores ranged from 5.64 to 6.36 in 2010, and from 4.71 to 7.63 in previous years.

\section{Kansas Biotic Index (KBI-NO)}

KBI-NO was specifically developed for the State of Kansas and is a genus-level index used to evaluate the effects of nutrients and oxygen demanding substances (Huggins and Moffett, 1988). The KBI-NO uses 10 orders of aquatic insects, and each of the taxa has tolerance values ranging from 0 to 5. Lower tolerance values indicate less tolerance to nutrients and oxygen-demanding substances and correspond to a lesser degree of stream degradation; but higher tolerance values indicate greater tolerance and a higher degree of stream degradation. KBI-NO ranged from 2.45 to 3.46 in 2010 (table 9). The site with the lowest KBI-NO score (indicating best relative condition) in 2010 was CE6 (Cedar Creek), and the site that had the highest was IN3a (Indian Creek). Urban sites (median 3.14) had KBI-NO scores that were significantly greater ( $z$-value $3.2, p$-value 0.0008$)$ than those for rural sites (median 2.75). Based on this metric, four sites (CE6, CA1, $\mathrm{KI} 5 \mathrm{~b}$, and KI6b) had KBI-NO scores in 2010 that met the KDHE criteria for full support of aquatic life (less than 2.61), compared to 4 sites in 2003 and 2 sites in 2004 and 2007 (table 9). Nine sites had KBI-NO scores that were partially supporting (between 2.61 and 2.99) of aquatic life in 2010, and 7 sites had nonsupporting scores (greater than 2.99).

\section{EPT Taxa Richness (EPTRich)}

EPT taxa richness is the number of species belonging to the insect orders Ephemeroptera (mayflies), Plecoptera (stoneflies), and Trichoptera (caddisflies). Most taxa in these orders generally are intolerant of environmental stressors and higher densities of these species usually are indicative of better water quality (Barbour and others, 1999). EPT taxa richness in 2010 ranged from 1 taxon at Indian Creek (site IN3a) and Turkey Creek (site TU1) to 16 taxa at Blue River near Stanley (site BL3, table 9). Rural sites (median 15 taxa) had significantly higher (z-value 3.9, $p$-value less than 0.0001) EPT taxa richness than urban sites (median 3). Seven sites (BL3, BL4, CA1, CE6, KI5b, KI6b, and LI1) had EPT taxa richness indicating that site conditions in 2010 fully supported aquatic life (KDHE criterion is greater than 12 EPT taxa), compared to, at most, only one site in previous years (BL4 in 2007). Three sites (BI1, BL5, and CE1) had EPT taxa richness between 8 and 12 in 2010, indicating partial support of aquatic life, and EPT taxa richness at the remaining 10 urban sites indicated nonsupport of aquatic life.

\section{Percentage of EPT (\%EPT)}

The EPT percentage metric is the number of taxa belonging to the orders Ephemeroptera (mayflies), Plecoptera (stoneflies), and Trichoptera (caddisflies) calculated as a percentage of the total number of organisms. Because EPT percentage 
provides information about the relative abundance of three mostly intolerant orders of aquatic insects, large populations of a few species can result in high percentages. Values in 2010 ranged from 0.5 percent at Indian Creek (site IN3a) to 42.8 percent at Captain Creek (site CA1), a State reference stream (table 9). Rural percentage of EPT (median 36.5) was significantly greater ( $z$-value 3.7 , p-value less than 0.0001$)$ than urban percentage of EPT (median 7.94). A total of 13 sites were classified as not supporting aquatic life in 2010 according to KDHE's criterion (less than 31 percent). The remaining seven sites were partially supporting of aquatic life. Site MI1 in 2003 is the only site that met the full support criterion for this metric during the study.

\section{Total Taxa Richness (TRich)}

Total taxa richness is the number of distinct taxa in a sample. The presence of higher numbers of distinct taxa is an indication that the food sources and habitats available at a site can support many species (Barbour and others, 1999). Overall median taxa richness in 2010 was 48 and was the highest of all years sampled (median 77 in 2003, 32 in 2003, and 33 in 2007) and ranged from 22 at Brush Creek (site BR2) to 63 at Cedar Creek (site CE6) and Blue River (site BL3). Rural sites (median 59 ) had significantly higher ( $z$-value 3.6, $p$-value 0.0002 ) total taxa richness than urban sites (median 32) indicating that urban sites had less diverse macroinvertebrate communities and likely their food sources and habitats also were less diverse than rural sites, on average.

\section{Other Metrics}

Aquatic macroinvertebrates commonly are classified into functional feeding groups, which separate taxa according to how they capture or ingest food. Scrapers are a functional feeding group that use their mouthparts to remove (or scrape) periphyton from surfaces. Knowledge about functional feeding groups provides information on community balance, types of food sources, and trophic dynamics (Barbour and others, 1999; Cummins, 1973). Specialized feeders, such as scrapers, are more sensitive organisms and higher densities are generally indicative of healthier streams (Barbour and others, 1996). Percentage of scrapers $(\% \mathrm{Sc})$ in 2010 ranged from 0 percent at Brush Creek (BR2) and Turkey Creek (TU1) to 20.4 percent at Cedar Creek (CE6, table 9). Rural percentage of scrapers (median 16 percent) was significantly greater (z-value 3.8 , $p$-value less than 0.0001) than urban percentage of scrapers (median 3.8 percent).

Many oligochaetes (worms) are pollution tolerant. Percent oligochaetes ranged from 0.4 at Captain Creek (CA1), a State reference site, to 33.3 at Turkey Creek (site TU1, table 9). Percentage oligochaetes (\%Olig) was significantly higher ( $z$-value 1.7, $p$-value 0.04$)$ for sites that were affected by wastewater (median 11 percent) than for sites that were unaffected by wastewater (median 6.9 percent). Urban sites (median 12 percent) had a significantly higher (z-value 3.3, $p$-value 0.0005 ) percentage of oligochaetes than rural sites (median 4.3 percent). This is the only metric out of the 11 metrics used in previous USGS reports in Johnson County (Poulton and others, 2007; Rasmussen and others, 2009) that was able to effectively differentiate among both wastewater and land-use effects.

Tanytarsini is an intolerant tribe of midges. Percent Tanytarsini (\%Tany) in 2010 ranged from 0 percent at many sites to 7.6 percent at Brush Creek (site BR2, table 9). No significant differences between site groups were seen with respect to wastewater or land use for this metric.

Percent intolerant organisms (\%Int-KBI) is the relative abundance of organisms that have KBI-NO tolerance values less than 3.0. Mean overall percent intolerant organisms in 2010 was 26 percent and ranged from 2.2 at Indian Creek (site IN6) to 48.1 at Captain Creek (site CA1), a State reference stream (table 9). Percent intolerant organisms for rural sites (median 42 percent) was significantly higher ( $z$-value 3.5 , $p$-value 0.0003 ) than for urban sites (median 13 percent).

Percentage of Ephemeroptera and Plecoptera (\%EP) is a modification of the percentage of EPT metric and omits the Trichoptera to account for the effect of higher relative abundances of tolerant net-spinning caddisflies (Hydropsychidae) that often are abundant in macroinvertebrate communities from larger urban streams (Poulton and others, 2007). Percentage of Ephemeroptera and Plecoptera ranged from 0.0 at Brush Creek (site BR2), Indian Creek (site IN3a), Little Mill Creek (LM1a), and Turkey Creek (site TU1) to 34.7 percent at Captain Creek (site CA1), a State reference stream (table 9). Mean percentage of Ephemeroptera and Plecoptera in 2010 was 14 percent. Percentage of Ephemeroptera and Plecoptera was significantly higher ( $z$-value $3.8, p$-value less than 0.0001$)$ for rural sites (median 29 percent) as compared to urban sites (median 0.5 percent).

The Shannon Diversity Index (SDI) is a core metric that measures community diversity and evenness (Washington, 1984). Higher values indicate more diversity and evenness of species and lower values indicate less diversity and less evenness of species. Shannon Diversity Index values in 2010 ranged from 2.6 at Brush Creek (site BR2) to 3.7 at Blue River (site BL3), Captain Creek (site CA1, a State reference site), and Cedar Creek (site CE6, table 9). Overall mean Shannon Diversity Index was 3.3. Rural sites (median 3.54) had significantly higher ( $z$-value $3.5, p$-value 0.0003$)$ Shannon Diversity than urban sites (median 3.03).

\section{Combined 10-Metric Scores}

Multimetric scores were developed by integrating 10 selected metrics into 1 overall score as an indicator of the relative biological quality of Johnson County streams (Poulton and others, 2007). Higher scores are indicative of better biological quality and lower scores are indicative of poorer biological quality. Ten-metric scores in 2010 ranged from 165 at Turkey Creek (site TU1) to 777 at Blue River (site BL3, table 9, fig. 10). The four sites with the lowest 10-metric scores (poorest quality) were the urban sites Turkey Creek (site TU1, not affected by wastewater), Indian Creek (sites 


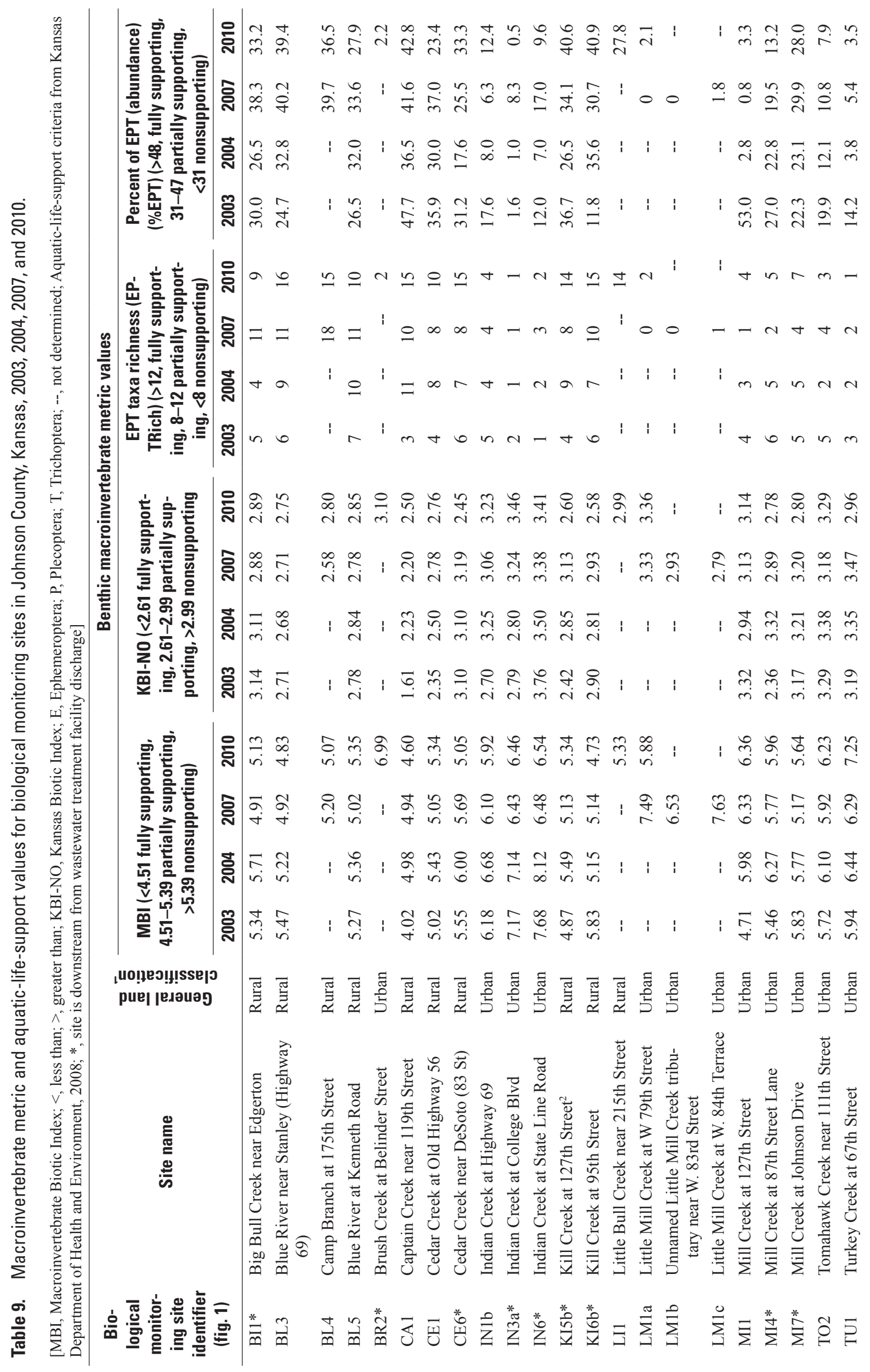




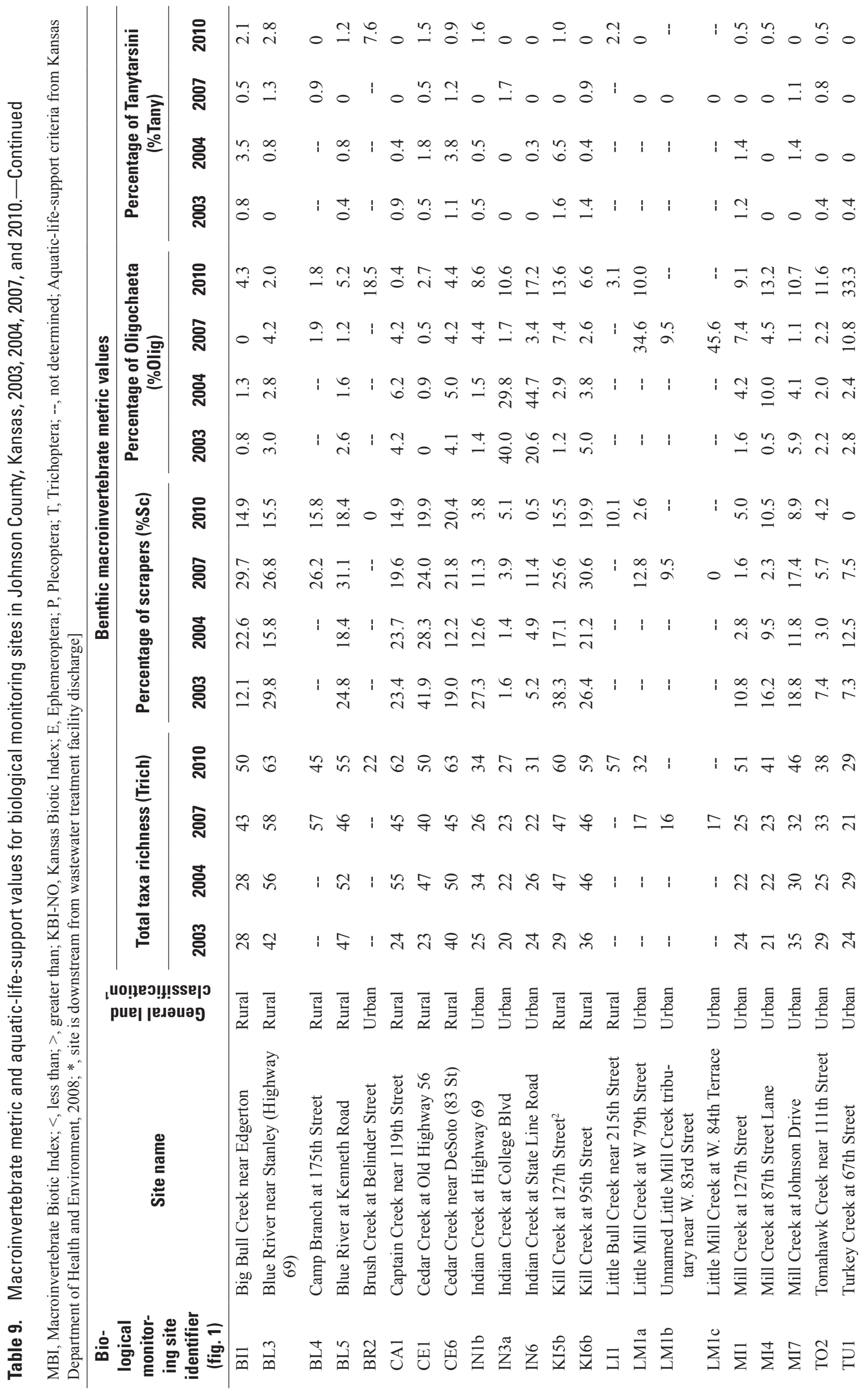




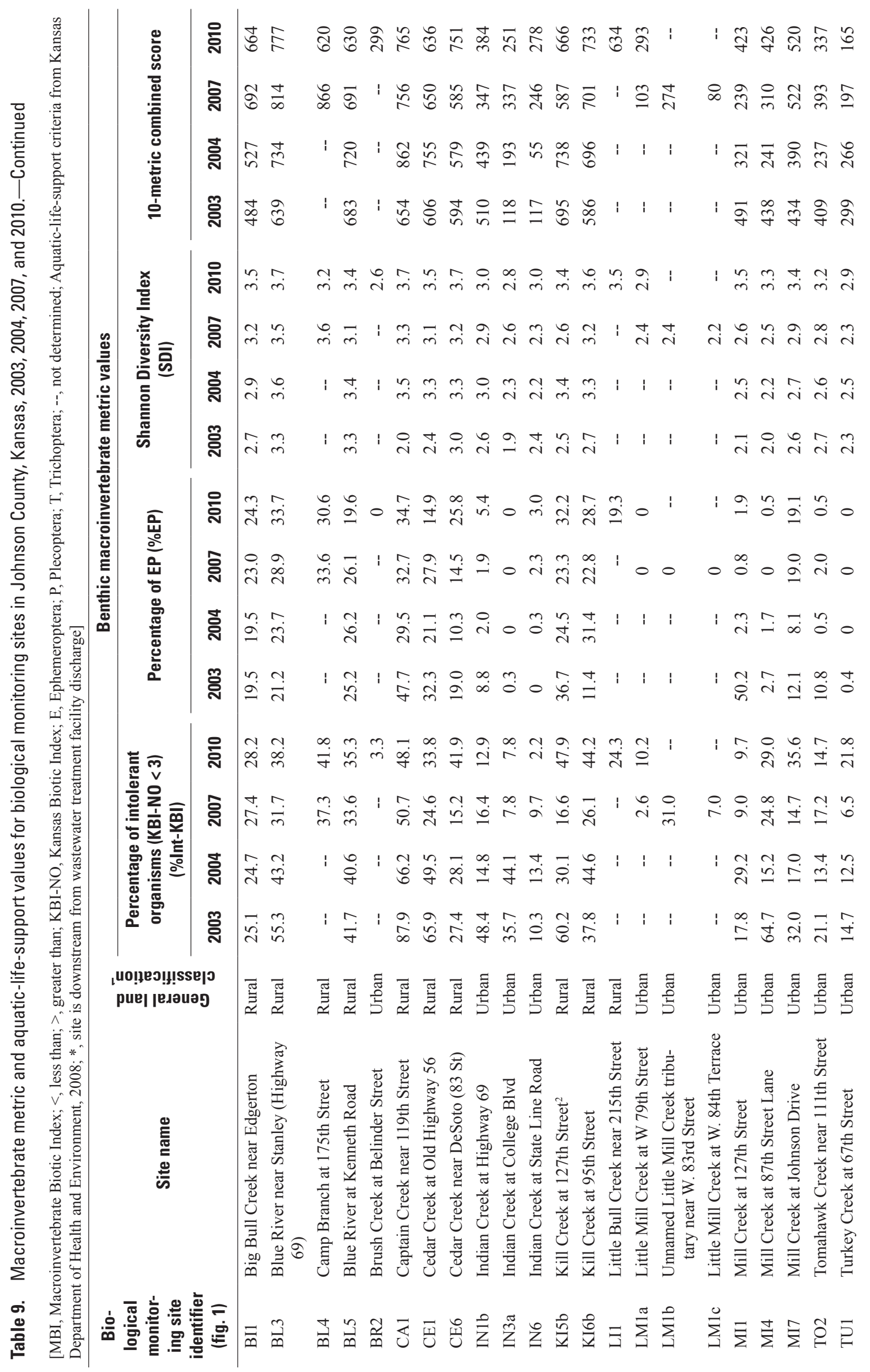


Table 9. Macroinvertebrate metric and aquatic-life-support values for biological monitoring sites in Johnson County, Kansas, 2003, 2004, 2007, and 2010.-Continued

[MBI, Macroinvertebrate Biotic Index; <, less than; >, greater than; KBI-NO, Kansas Biotic Index; E, Ephemeroptera; P, Plecoptera; T, Trichoptera; --, not determined; Aquatic life support criteria from Kansas Department of Health and Environment, 2008; *, site is downstream from wastewater treatment facility discharge]

\begin{tabular}{|c|c|c|c|c|c|c|}
\hline \multirow{2}{*}{$\begin{array}{c}\text { Bio- } \\
\text { logical } \\
\text { monitor- } \\
\text { ing site } \\
\text { identifier } \\
\text { (fig. 1) }\end{array}$} & \multirow[b]{2}{*}{ Site name } & \multirow[b]{2}{*}{$\begin{array}{l}\text { General land } \\
\text { classification }{ }^{1}\end{array}$} & \multicolumn{4}{|c|}{ Aquatic-life-support status ${ }^{3}$} \\
\hline & & & 2003 & 2004 & 2007 & 2010 \\
\hline BI1 & Big Bull Creek near Edgerton & Rural & 1.25 & 1.00 & 2.00 & 2.00 \\
\hline BL3 & Blue River near Stanley (Highway 69) & Rural & 1.25 & 2.00 & 2.00 & 2.25 \\
\hline BL4 & Camp Branch at 175 th Street & Rural & -- & -- & 2.50 & 2.25 \\
\hline BL5 & Blue River at Kenneth Road & Rural & 1.50 & 2.00 & 2.00 & 1.75 \\
\hline $\mathrm{BR} 2$ & Brush Creek at Belinder Street & Urban & -- & -- & -- & 1.00 \\
\hline CA1 & Captain Creek near 119th Street & Rural & 2.25 & 2.25 & 2.25 & 2.50 \\
\hline CE1 & Cedar Creek at Old Highway 56 & Rural & 2.00 & 2.00 & 2.00 & 1.75 \\
\hline CE6 & Cedar Creek near DeSoto (83 St) & Rural & 1.25 & 1.00 & 1.25 & 2.50 \\
\hline IN1b & Indian Creek at Highway 69 & Urban & 1.25 & 1.00 & 1.00 & 1.00 \\
\hline IN3a & Indian Creek at College Blvd & Urban & 1.25 & 1.25 & 1.00 & 1.00 \\
\hline IN6 & Indian Creek at State Line Road & Urban & 1.00 & 1.00 & 1.00 & 1.00 \\
\hline $\mathrm{KI} 5 \mathrm{~b}$ & Kill Creek at 127th Street $^{2}$ & Rural & 2.00 & 1.50 & 1.75 & 2.50 \\
\hline KI6b & Kill Creek at 95th Street & Rural & 1.25 & 1.75 & 1.75 & 2.50 \\
\hline LI1 & Little Bull Creek near 215th Street & Rural & -- & -- & -- & 2.00 \\
\hline LM1a & Little Mill Creek at W 79th Street & Urban & -- & -- & 1.00 & 1.00 \\
\hline LM1b & Unnamed Little Mill Creek tributary near W. 83rd Street & Urban & -- & -- & 1.25 & -- \\
\hline LM1c & Little Mill Creek at W. 84th Terrace & Urban & -- & -- & 1.25 & -- \\
\hline MI1 & Mill Creek at 127 th Street & Urban & 1.75 & 1.25 & 1.00 & 1.00 \\
\hline MI4 & Mill Creek at 87th Street Lane & Urban & 1.50 & 1.00 & 1.25 & 1.25 \\
\hline MI7 & Mill Creek at Johnson Drive & Urban & 1.00 & 1.00 & 1.25 & 1.25 \\
\hline TO2 & Tomahawk Creek near 111th Street & Urban & 1.00 & 1.00 & 1.00 & 1.00 \\
\hline TU1 & Turkey Creek at 67 th Street & Urban & 1.00 & 1.00 & 1.00 & 1.25 \\
\hline
\end{tabular}

${ }^{1}$ Urban sites have greater than 50 percent urban land use and greater than 15 percent impervious surface in the upstream drainage area.

${ }^{2}$ Site moved from 135th to 127th Street in 2007.

${ }^{3}$ Mean of scores for four Kansas Department of Health and Environment (KDHE) metrics (MBI, KBI-NO, EPTRich, and \%EPT); fully supporting $>2.49$, partially supporting $1.5-2.49$, nonsupporting $<1.5$.

IN3a and IN6, both affected by wastewater), and Little Mill Creek (LM1a, not affected by wastewater). The four sites with the highest 10-metric scores (best quality) in 2010 were the rural sites Blue River (site BL3, not affected by wastewater), Captain Creek (site CA1, a State reference site, and not affected by wastewater), Cedar Creek (site CE6, affected by wastewater), and Kill Creek (site KI6b, affected by wastewater). Ten-metric scores were significantly higher ( $z$-value 3.9, $p$-value less than 0.0001) for rural sites (median 654) than urban sites (median 311), indicating that, in general, less disturbed streams are located in rural areas of Johnson County. A notable improvement in the 10-metric score occurred at the Big Bull Creek site (BI1) during 2007 and 2010 compared to scores in 2003 and 2004 (fig. 10), which may be related to reductions in upstream wastewater discharges.

\section{Stream Quality Based on Aquatic-Life-Support Categories}

Aquatic-life-support categories are indicative of the ability of a stream to support a certain level of aquatic life. The ranges used for scoring the four metrics (MBI, KBI-NO, EPT Richness, and percentage of EPT) are based on the statewide KDHE database for all streams in Kansas (Kansas Department of Health and Environment, 2010a) and are shown in table 9. Aquatic-life-support status for each site was determined using the mean of individual scores assigned for each of the four KDHE metrics; full support scores, greater than 2.49; partial support scores, 1.5-2.49; nonsupport scores, less than 1.5. Four sites (about 19 percent) in 2010 were fully supporting of aquatic life: Captain Creek (site CA1, a State reference site), Cedar Creek (site CE6), and two Kill Creek sites (KI5b and 

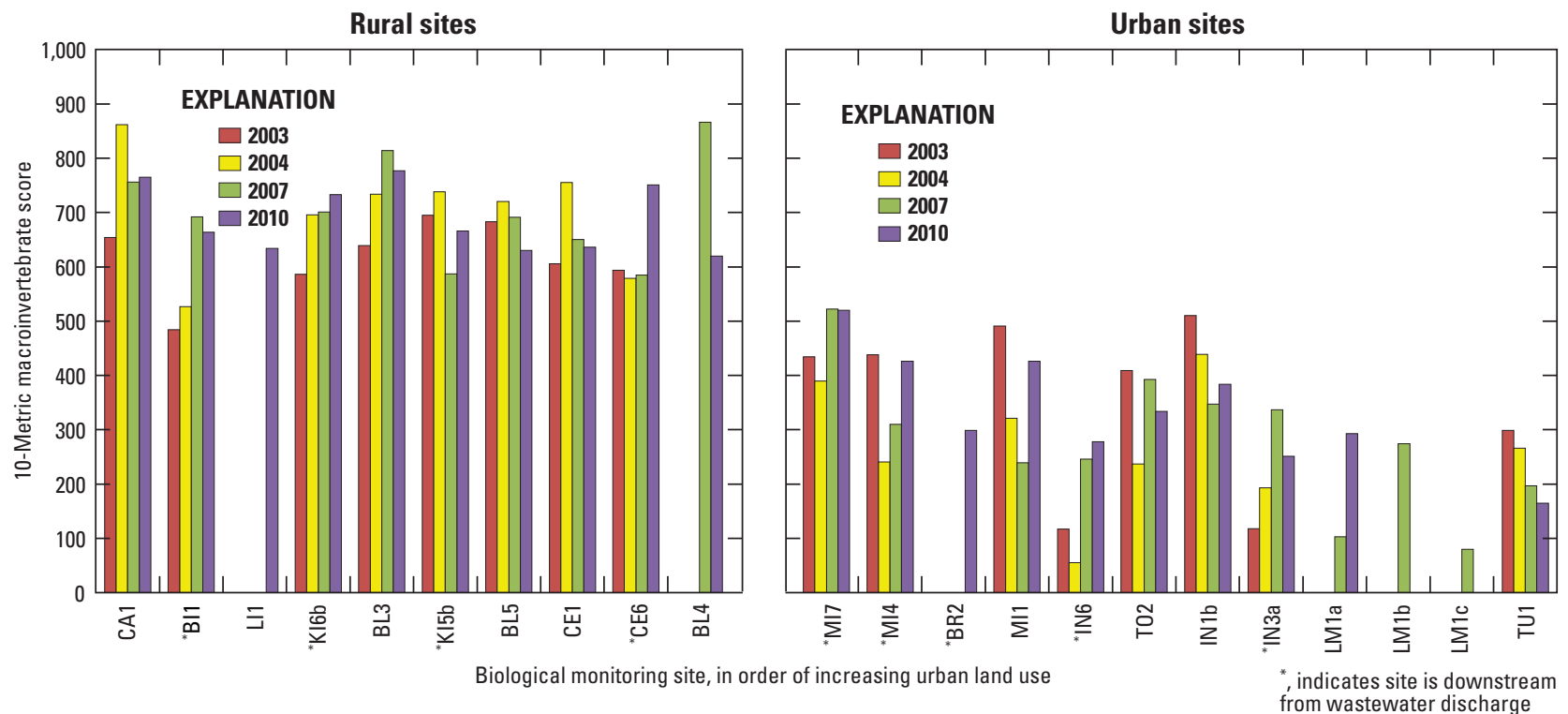

Figure 10. Combined 10-metric macroinvertebrate scores for biological monitoring sites in Johnson County, Kansas, 2003, 2004, 2007, and 2010.

KI6b, table 9, fig. 11). This is a notable difference compared to previous years when no sites were fully supporting (in 2003 and 2004) or just one site was fully supporting (a Blue River tributary in 2007). During 2010 about 29 percent of the sites were partially supporting of aquatic life and about 52 percent of the sites were nonsupporting of aquatic life. All nonsupporting sites were urban. Rural sites (median 2.25) had significantly higher ( $z$-value 4.0, $p$-value less than 0.0001$)$ aquaticlife-support status scores than urban sites (median 1.00). Figure 11 shows the general pattern that through the years of the study, urban sites' life-support scores either have trended downward, or remained about stable within the nonsupport range. In contrast, most rural sites' scores either were at least partially supporting across the study period, or had become so by 2010 .

Aquatic-life-support status for stream sites in Johnson County generally is consistent with anthropogenic disturbance maps developed by KDHE (fig. 12). The maps were developed using geographical databases to identify minimally disturbed watersheds within various ecoregions (Angelo and others, 2010). Ecoregions generally are similar geographical areas defined and differentiated by combining suitable landscape characteristics such as physiography, geology, climate, soils, and vegetation (Angelo and others, 2010). It is within this framework that KDHE developed a watershed anthropogenic disturbance index to rank the State's watersheds and eventually identify candidate reference streams. The index incorporated geographical databases with species (native fishes, mussels, and invertebrates) diversity data, and used cluster analyses and predictive modeling to develop disturbance maps.

Relative to the rest of the State (fig. 12A), most Johnson County watersheds fall into the most severe category of disturbance (fig. 12B) because of the large proportions of urban and agricultural land use. Streams that have met aquatic-life-support criteria at least once during the study period are located within close upstream proximity to some of the less disturbed areas of the county. Captain Creek, a candidate reference stream located in western Johnson County and considered a minimally disturbed stream in this study, includes a considerable area of highly disturbed land within the lower parts of the watershed.

\section{Comparison of Stream Biological Conditions Among Watersheds}

The monitoring sites were divided into three categories of relative biological effects on stream health from human disturbance (least affected, moderately affected, and most affected) as indicated by the annual 10-metric macroinvertebrate scores (fig. 13). Sites were categorized as least affected when scores were less than 315 , moderately affected when scores ranged from 315 to 590, and most affected when scores were greater than 590. Based on these categories, seven sites in the rural western and southern parts of the county (BL3, BL4, BL5, CA1, CE1, KI5b, and KI6b) were least affected by disturbance and showed no change in category assignment from 2003 to 2010 (except site BL4 where data were first collected in 2007). Two highly urban sites in northeastern Johnson County (IN6 and TU1) were most affected by human disturbance and also showed no change. Two rural sites (BI1 and CE6) showed improvements in macroinvertebrate metric scores since 2004. Improvement in biological communities at these sites is consistent with improvement in streambed-sediment quality at the same two sites, but improvements may be related to other unknown factors as well. Positive changes in macroinvertebrate community in Big Bull Creek (site BI1) may be related to an upstream wastewater discharge that was discontinued in 


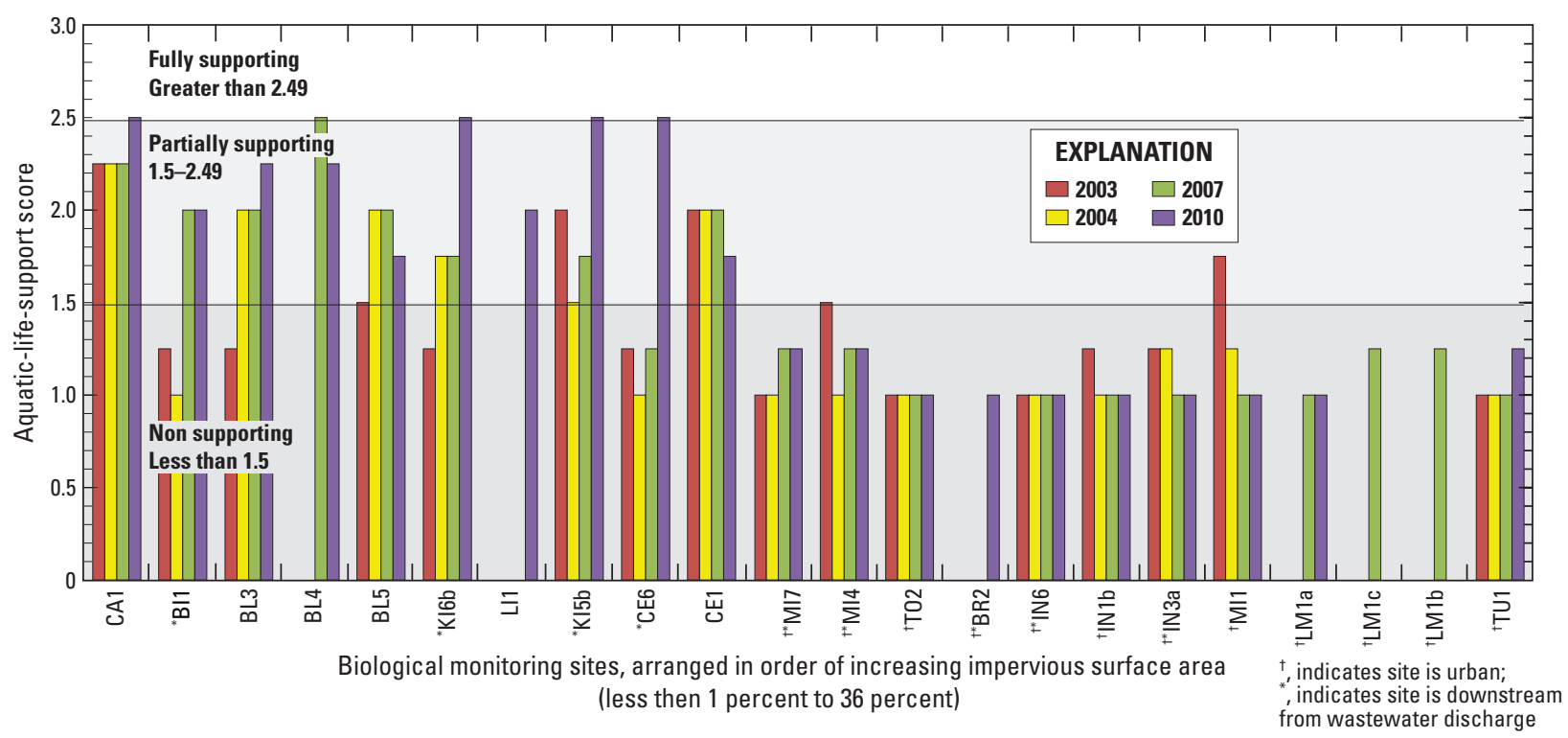

Figure 11. Kansas Department of Health and Environment aquatic-life-support status in relation to percent impervious surface area for biological monitoring sites in Johnson County, Kansas, 2003, 2004, 2007, and 2010.

2007. The reasons for detectable improvements in stream conditions at the Cedar Creek site are unknown. Spatial patterns of relative biological effects indicated by the classification of sampled sites generally were consistent with relative anthropogenic disturbance maps (fig. 12C).

\section{Relations Between Stream Biological Conditions and Environmental Variables}

Nonparametric Spearman rank correlation coefficients for all combinations of water chemistry, streambed-sediment chemistry, land use, streamflow, habitat, periphyton, and macroinvertebrate variables were computed. Correlations provide an indication of how well the ranges in biological conditions correspond with environmental variables that may affect them. Correlation coefficients (rho values, $p$ ) shown in table 10 are statistically significant with $p$-values less than 0.01 . Highlighted values are highly significant with $p$-values less than 0.001. Data from 2003, 2004, 2007, and 2010 were included in the analysis. Although correlations were calculated for many combinations of variables, table 10 was reduced generally to include only the variables that were most commonly significantly correlated with biological variables. The 10-metric macroinvertebrate score and the most important metrics making up that score were included in the table as biological indicators of stream health. One additional macroinvertebrate metric, percent non-insects, also was included because it was strongly correlated with many environmental variables. There were no strong correlations between environmental factors and periphyton metrics so they were not included in the table. Other studies have determined that nutrient concentrations and, in some cases, environmental factors such as substrate type and light availability were important predictors of algal metrics (Black and others, 2011). Correlations with periphyton metrics may not have been evident in this study because of low variability among sites. In a national study, periphyton metrics were able to differentiate between rural and urban watersheds in most ecoregions of the United States; however, this did not apply to the Northern Plains ecoregion (Porter and others, 2008) in which Johnson County is located.

Watershed impervious surface and land-use variables were significantly ( $p$-value less than 0.001$)$ correlated with all invertebrate metrics (table 10). Percentage of impervious surface area and urban land use were negatively correlated with better-quality biological metric indicators. Percentage of cropland (row crops), grassland, and woodland were positively correlated with better-quality biological metric indicators. Although cropland has been shown to negatively affect biological communities in streams because of increased runoff of sediment, nutrients, and pesticides (Cooper, 1993; Waters, 1995), the magnitude of the effects is dependent on the spatial arrangement (Sponseller and others, 2001). The watersheds with the highest percentages of cropland (row crops, ranging from 20-34 percent for Big Bull, Little Bull, Captain, Cedar, and Kill Creeks, table 1) had low percentages of cropland within the stream buffer zones.

Some streamflow metrics were strongly correlated with biological variables and land use and habitat variables (table 10). Of the 3 streamflow metrics retained in the table (base-flow index, ratio of 75 th to 25 th percentile streamflow, and average daily streamflow), ratio of 75 th to 25 th percentile streamflow, which is a measure of the magnitude and variability in streamflow conditions, was most strongly correlated with individual invertebrate metrics and the 10-metric score. Higher ratio value indicates more variable streamflow, which decreased with increasing watershed size (table 10). Invertebrate diversity and richness metrics often improve with 

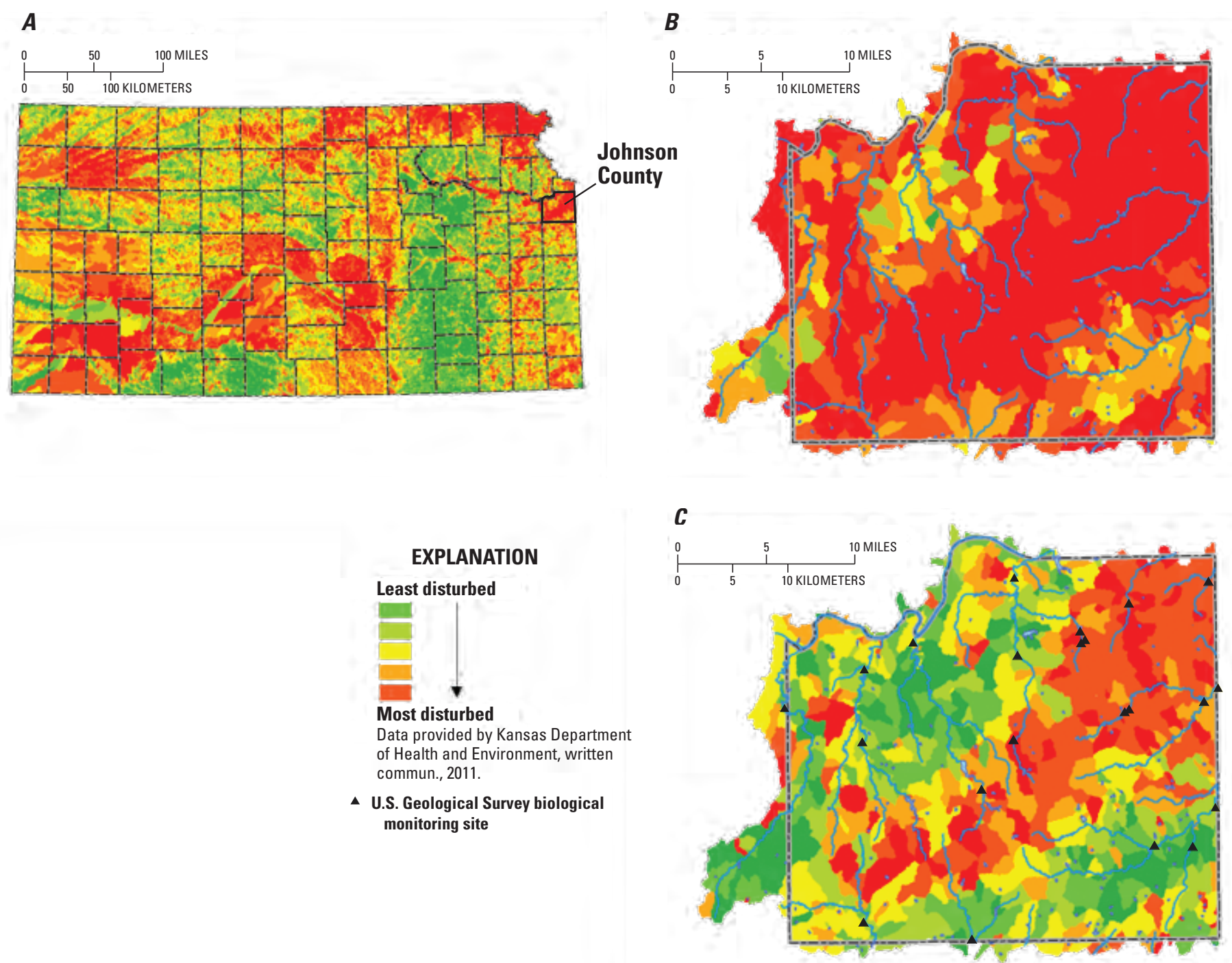

Figure 12. Anthropogenic disturbance maps for watersheds in $A$, Kansas, $B$, Johnson County, and $C$, Johnson County, with watershed disturbance scores range-standardized among themselves.

decreased streamflow variability because it promotes habitat stability (Horowitz, 1978); however, in this study invertebrate diversity and richness measures worsened with decreasing streamflow variability, likely because of the effects of urbanization. As base-flow index (base flow divided by total flow volume) increased, as often occurs when runoff is redistributed from base flow to more flashy stormflow with increasing urbanization (Konrad and Booth, 2005), several invertebrate metric scores worsened. Average daily streamflow, which increased as urbanization increased, was negatively correlated with several individual metrics and the 10-metric score.

Several stream-water and streambed-sediment chemistry variables were correlated with biological variables (table 10). Specific conductance of water and sum of PAH concentrations in streambed sediment were highly negatively correlated ( $p$-value less than 0.001) with macroinvertebrate conditions indicated by the 10-metric score and all of the individual metrics that make up the 10-metric score. Specific conductance of water and PAHs in sediment are known to have adverse effects on biological communities at high concentrations (U.S. Environmental Protection Agency, 2008), but both variables also were highly correlated with the land-use variables and, therefore, simply may be redundant indicators of urbanization. Total phosphorus in water did not correlate with any biological or land-use variables, but did correlate with distance downstream from wastewater discharge. Total nitrogen in sediment did not correlate with any other variables including land use. Total nitrogen in water correlated with most of the invertebrate variables, and total phosphorus in sediment correlated with the invertebrate richness metrics and Shannon Diversity Index. When only 2007 data were used (Rasmussen and others 2009), the nutrient relations were weak or not detected, possibly because the dataset was too small to detect significant patterns.

Stream buffer land use variables were closely related to biological conditions (table 10). Urban land use for the full extent of the 30-meter buffer upstream from sampling sites was highly correlated ( $p$-value less than 0.001 ) to all macroinvertebrate metrics. Reach-level urban land use also was highly 


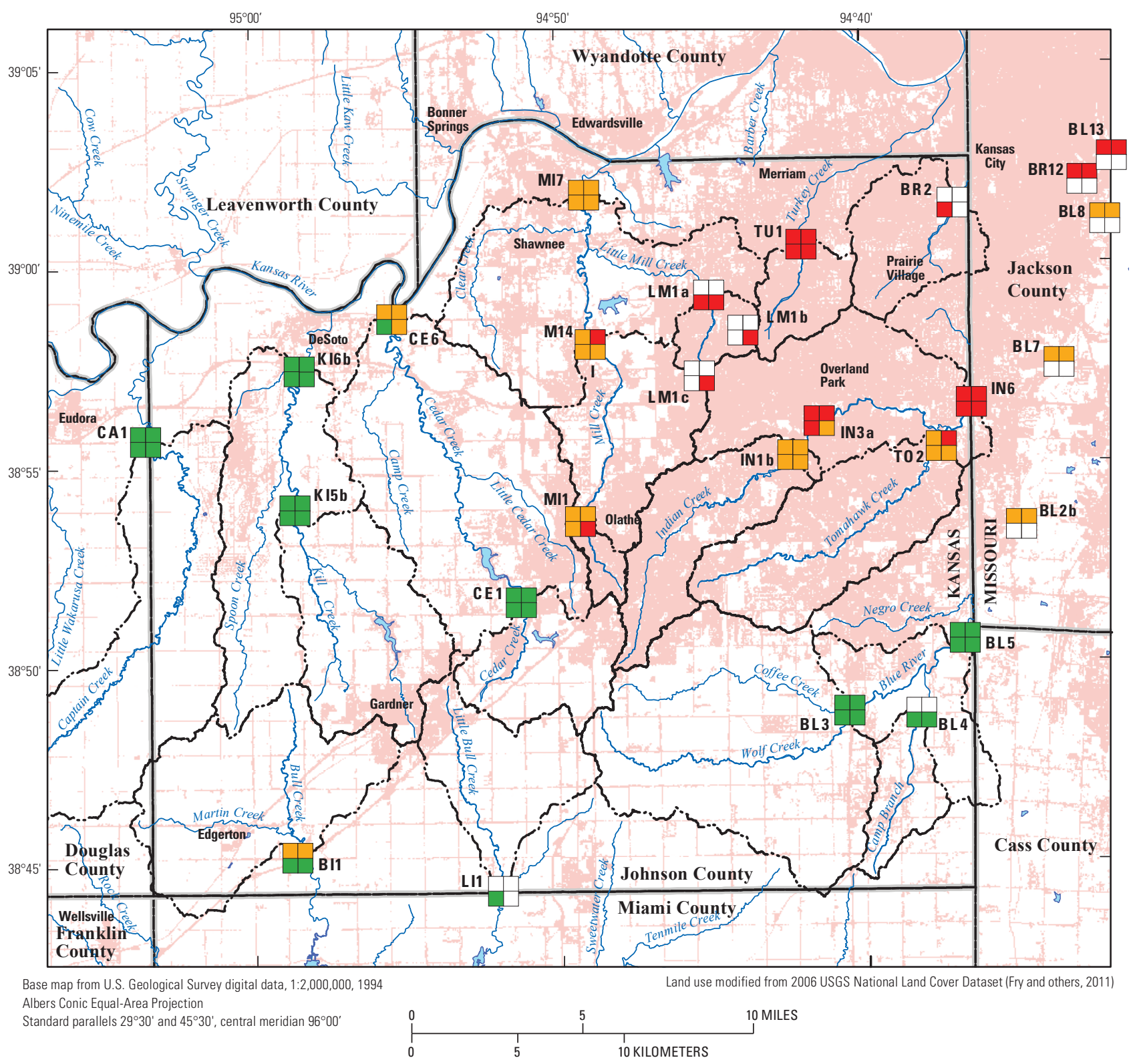

EXPLANATION

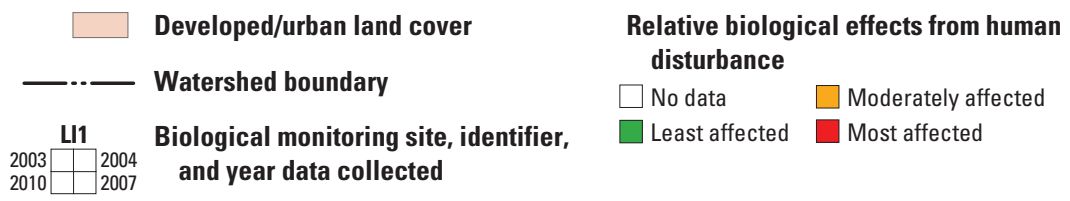

Figure 13. Relative effects from human disturbance on stream health as indicated by 10-metric macroinvertebrate scores at biological monitoring sites in and near Johnson County, Kansas, 2003, 2004, 2007, and 2010.

correlated with most metrics. The segment-level land-use data were useful in explaining relations with macroinvertebrate assemblages except forest land use, which was highly variable among sites. Density of stormwater entry points, determined by dividing the number of stormwater inlets adjacent to the stream in the segment upstream from the sampling site by the length of the segment, was significantly negatively correlated
( $p$-value less than 0.001 ) with all biological conditions indicated by macroinvertebrate metrics. Density of stormwater outfalls also was positively correlated with specific conductance, total nitrogen and suspended sediment in water, and PAHs in sediment indicating that stormwater outfalls contribute to direct transport of these potentially harmful constituents to stream systems. 
Table 10. Spearman correlation matrix for selected biological and environmental variables using data from biological monitoring sites in Johnson County, Kansas, 2003, 2004, 2007, and 2010. Correlation coefficents shown are significant at $p<0.01$. Shading indicates values significant at $p<0.001$.

$[<$, less than; PAHs, polycyclic aromatic hydrocarbons; MBI, Macroinvertebrate Biotic Index; KBI-NO, Kansas Biotic Index; E, Ephemeroptera; P, Plecoptera; T, Trichoptera; --, correlation not significant]

\begin{tabular}{|c|c|c|c|c|c|c|c|c|c|c|c|c|c|c|c|c|c|c|c|c|c|}
\hline & 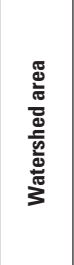 & 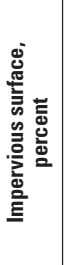 & 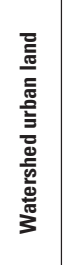 & 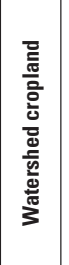 & 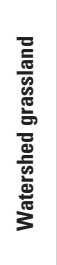 & 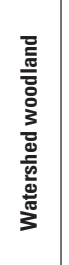 & 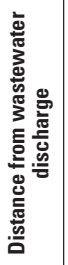 & 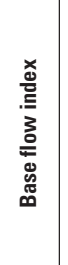 & 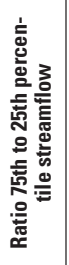 & 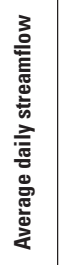 & 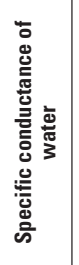 & 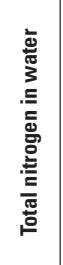 & 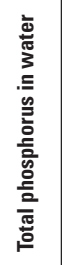 & 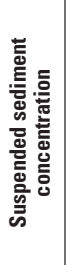 & 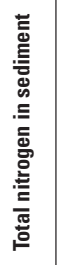 & 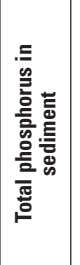 & 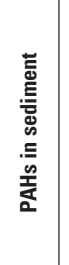 & 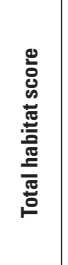 & 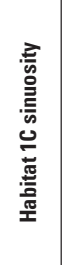 & 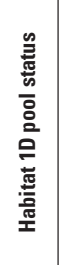 & 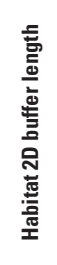 \\
\hline \multicolumn{22}{|l|}{ Watershed area } \\
\hline Impervious surface, percent & -0.50 & & & & & & & & & & & & & & & & & & & & \\
\hline Watershed urban land & -0.57 & .95 & & & & & & & & & & & & & & & & & & & \\
\hline Watershed cropland & 0.50 & -.91 & -.96 & & & & & & & & & & & & & & & & & & \\
\hline Watershed grassland & 0.57 & -.95 & -.96 & 91 & & & & & & & & & & & & & & & & & \\
\hline Watershed woodland & 0.61 & -.85 & -.84 & .79 & .86 & & & & & & & & & & & & & & & & \\
\hline Distance from wastewater discharge & -0.46 & -- & -- & -- & -- & -- & & & & & & & & & & & & & & & \\
\hline Base-flow index & 0.87 & .92 & .90 & -.90 & -.90 & -- & -.54 & & & & & & & & & & & & & & \\
\hline Ratio 75th to 25th percentile streamflow & -0.74 & -.92 & -.84 & .83 & .97 & -- & .62 & -.91 & & & & & & & & & & & & & \\
\hline Average daily streamflow & 0.95 & .82 & .90 & -.90 & -.83 & -- & -- & .89 & -.84 & & & & & & & & & & & & \\
\hline Specific conductance of water & -0.51 & .84 & .84 & -.76 & -.84 & -.79 & -- & .78 & -.88 & -- & & & & & & & & & & & \\
\hline Total nitrogen in water & -- & .43 & .42 & -- & -.50 & -.52 & -- & -- & -- & -- & .52 & & & & & & & & & & \\
\hline Total phosphorus in water & 0.56 & -- & -- & -- & -- & -- & -.79 & -- & -- & -- & -- & .50 & & & & & & & & & \\
\hline Suspended sediment concentration & -- & -- & -- & -- & .42 & -- & .45 & -- & -- & -- & -- & -- & -- & & & & & & & & \\
\hline Total nitrogen in sediment & -- & -- & -- & -- & -- & -- & -- & -- & -- & -- & -- & -- & -- & -- & & & & & & & \\
\hline Total phosphorus in sediment & -- & -- & -- & -- & -.35 & -- & -.47 & -- & -- & -- & -- & .50 & -- & -.71 & .42 & & & & & & \\
\hline PAHs in sediment & -0.39 & .84 & .83 & -.83 & -.85 & -.79 & -- & .68 & -.77 & .57 & .73 & .47 & -- & -- & -- & -- & & & & & \\
\hline Total habitat score & -- & -.60 & -.57 & .60 & .57 & .54 & -- & -.65 & .72 & -- & -.50 & -.49 & -- & -- & -- & -- & -.62 & & & & \\
\hline Habitat 1C sinuosity & 0.59 & -.65 & -.74 & .74 & .64 & .64 & -- & -- & -- & -.55 & -.57 & -- & -- & -- & -- & -- & -.57 & .38 & & & \\
\hline Habitat 1D pool status & -- & -.55 & -.55 & .53 & .45 & .43 & -- & -.57 & .52 & -.52 & -.51 & -- & -- & \begin{tabular}{l|}
- \\
\end{tabular} & -- & -- & -.59 & .49 & .52 & & \\
\hline Habitat $2 \mathrm{D}$ buffer length & -- & -.65 & -.71 & .75 & .65 & .58 & -- & -.67 & .80 & -.85 & -.48 & -- & -- & -- & -- & -- & -.59 & .62 & .79 & .44 & \\
\hline Habitat 2E buffer width & -- & -- & -.31 & .35 & -- & -- & -- & -.73 & .66 & -.58 & -- & -.50 & -- & -- & -- & -- & -.39 & .62 & -- & .62 & .42 \\
\hline Habitat 2F altered banks & -- & -.43 & -.40 & .37 & .40 & .54 & -- & -- & -- & -.53 & -.48 & -.57 & -- & -- & -- & -- & -.56 & .58 & -- & .59 & .37 \\
\hline Habitat 3C riffle substrate embeddedness & 0.38 & -.59 & -.68 & .69 & .63 & .52 & -- & -.78 & .83 & -.54 & -.54 & -.49 & -- & -- & -- & -- & -.71 & .81 & .56 & .48 & .68 \\
\hline Habitat 3D sediment deposition & 0.47 & -.47 & -.40 & .40 & .48 & .52 & -.43 & -- & -- & -- & -- & -- & -- & -- & -- & -- & -.46 & .72 & -- & -- & -- \\
\hline Habitat 3E substrate cover diversity & -- & -.59 & -.62 & .62 & .58 & .50 & .33 & -.55 & .72 & -- & -.58 & -.45 & -- & -- & -- & -.42 & -.63 & .53 & .61 & .65 & .60 \\
\hline Habitat $3 \mathrm{~F}$ riffle substrate composition & 0.44 & -.40 & -.37 & .37 & -- & .56 & -- & -- & -- & -- & -- & -- & -- & -- & -- & -- & -.43 & .71 & .30 & -- & .36 \\
\hline Full extent buffer, agriculture & -- & -.47 & -.45 & .42 & .49 & .47 & -- & -- & -- & -- & -.427 & -- & -- & -- & -- & -- & -.48 & -- & .45 & .37 & .43 \\
\hline Full extent buffer, forest & -- & -.65 & -.65 & .71 & .59 & .41 & -- & -.90 & .87 & -.99 & -.46 & -- & -- & -- & -- & -- & -.58 & .53 & .58 & .60 & .68 \\
\hline Full extent buffer, urban & -- & .83 & .88 & -.87 & -.86 & -.83 & -- & -- & -.68 & .67 & .74 & .48 & -- & -- & -- & -- & .78 & -.52 & -.75 & -.44 & -.78 \\
\hline Segment buffer, agriculture & 0.38 & -.53 & -.51 & .48 & .49 & .78 & -- & -- & -- & -- & -.50 & -.48 & -- & .41 & -- & -- & \begin{tabular}{l|l}
-.53 \\
\end{tabular} & -- & .52 & -- & .41 \\
\hline Segment buffer, forest & -0.37 & -- & -- & -- & -- & -- & .44 & -- & -- & -.98 & -- & -- & -- & -- & -- & -- & -- & -- & -- & .42 & -- \\
\hline Segment buffer, urban & -0.49 & .40 & .40 & -.37 & -.41 & -.53 & -- & -- & -- & -- & .44 & .62 & -- & -- & -- & -- & .48 & -.59 & -- & -- & -.39 \\
\hline Segment buffer, roadways & -0.50 & .85 & .88 & -.91 & -.86 & -.75 & -- & .78 & -.81 & .90 & .71 & -- & -- & -- & -- & -- & .80 & -.56 & -.82 & -.50 & -.84 \\
\hline Reach buffer, forest & -- & -.64 & -.65 & .70 & .59 & .38 & -- & -.92 & .90 & -.98 & -.45 & -- & -- & -- & -- & -- & -.57 & .51 & .57 & .59 & .67 \\
\hline Reach buffer, urban & -0.52 & .88 & .92 & \begin{tabular}{|l|l}
-.93 \\
\end{tabular} & -.88 & -.77 & -- & .78 & -.81 & .90 & .74 & -- & -- & -- & -- & -- & .79 & -.57 & -.81 & -.52 & -.83 \\
\hline Density of stormwater entry points & -0.51 & .89 & .91 & -.91 & -.83 & -.84 & -- & -- & -- & .73 & .80 & .42 & -- & .50 & -- & -- & .80 & -.55 & -.65 & -.48 & -.63 \\
\hline Density of septic systems & -- & -- & -- & -- & .57 & .63 & -- & -- & -- & -- & -- & -.88 & -- & -- & -- & -- & -- & .57 & -- & -- & -- \\
\hline Benthic MBI & -- & .77 & .78 & -.77 & -.59 & -.71 & -- & .63 & -.67 & .56 & .79 & .52 & -- & -.42 & -- & -- & .80 & -.51 & -.50 & -.49 & -.53 \\
\hline Benthic KBI-NO & -- & .59 & .59 & \begin{tabular}{|l|l|}
-.56 \\
\end{tabular} & -.58 & -.52 & -- & .53 & -.70 & -- & .62 & .52 & -- & -.41 & -- & -- & .62 & -.42 & -.35 & -.46 & -.45 \\
\hline Benthic EPT Richness & 0.38 & -.77 & -.77 & .74 & .79 & .78 & -- & -- & .57 & -- & -.81 & -.63 & -- & .46 & -- & -.45 & -.76 & .59 & .49 & 41 & .58 \\
\hline Benthic percent EPT & 0.39 & -.80 & -.80 & .78 & .80 & .75 & -- & \begin{tabular}{l|l|}
-.57 \\
\end{tabular} & .64 & -.51 & -.82 & -.48 & -- & -- & -- & -- & -.77 & .48 & .49 & .40 & .50 \\
\hline Benthic total richness & 0.37 & -.63 & -.64 & .62 & .69 & .70 & -- & -- & .51 & -- & -.82 & -.61 & -- & .43 & -- & -.53 & -.64 & .49 & .46 & -- & .51 \\
\hline Benthic percent scrapers & 0.33 & -.72 & -.70 & .72 & .70 & .69 & -- & -- & .58 & -- & -.58 & -.50 & -- & -- & -- & -- & -.80 & .63 & .49 & .44 & .59 \\
\hline Benthic percent intolerant organisms & -- & -.65 & -.63 & .61 & .63 & .60 & -- & -- & .61 & -- & -.67 & -.57 & -- & .49 & -- & -- & -.66 & .46 & .44 & .44 & .49 \\
\hline Benthic percent EP & 0.32 & -.80 & -.78 & .77 & .79 & .75 & -- & -.68 & .78 & -.58 & -.86 & -.61 & -- & .42 & -- & -- & -.76 & .55 & .51 & .45 & .51 \\
\hline Benthic Shannon Diversity Index & -- & -.56 & -.58 & .56 & .62 & .60 & -- & .57 & .56 & -.50 & -.77 & -.54 & -- & .50 & -- & -.56 & -.52 & .46 & .43 & -- & .52 \\
\hline Benthic 10-metric score & 0.31 & -.83 & -.82 & .79 & .83 & .79 & -- & -.57 & .76 & -.58 & -.83 & -.57 & -- & .44 & -- & -- & -.85 & .60 & .57 & .48 & .64 \\
\hline Benthic percent non-insects & -0.41 & .79 & .77 & \begin{tabular}{|l|}
-.77 \\
\end{tabular} & -.76 & -.63 & -- & .83 & -- & .75 & .59 & -- & -- & -- & -- & .43 & .62 & -.43 & -.54 & -- & -.57 \\
\hline
\end{tabular}




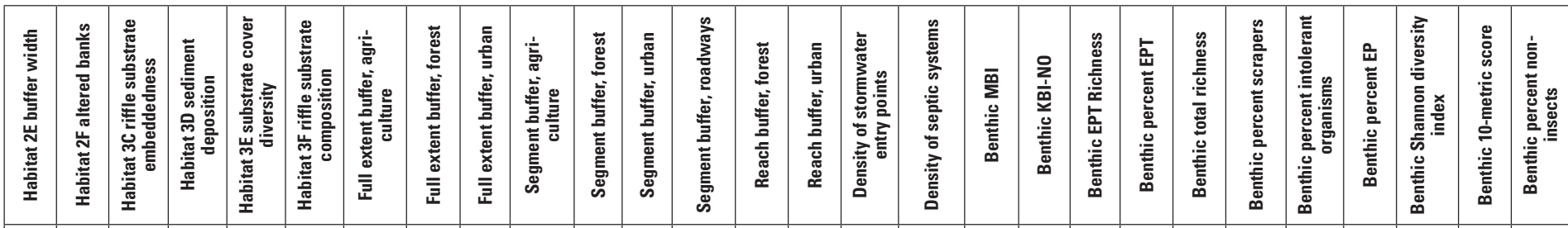

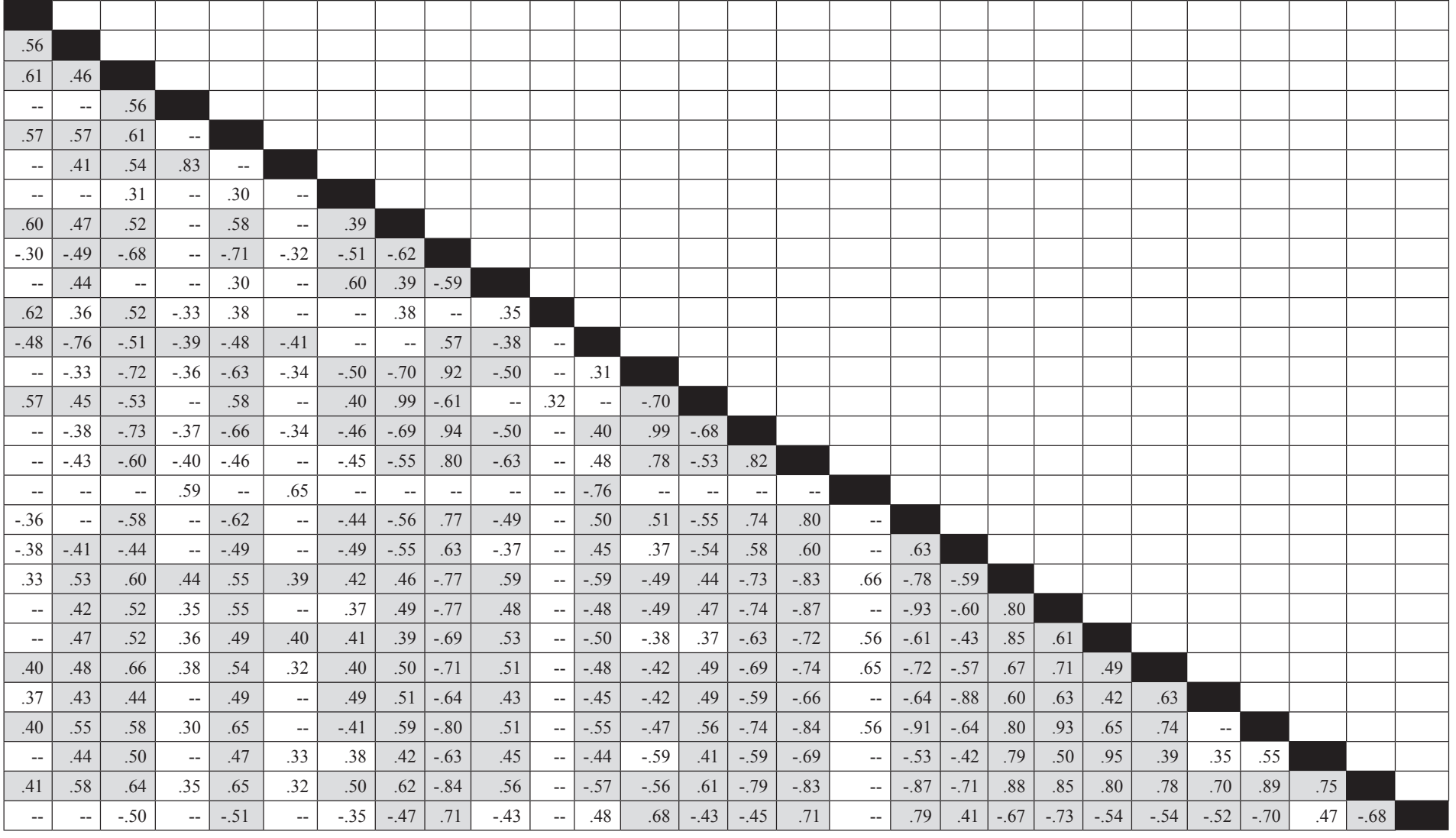


The total habitat score was strongly correlated with the 10-metric macroinvertebrate score and with most of the individual metrics. The most important habitat variables were sinuosity (habitat variable 1C), buffer length (2D), riffle substrate embeddedness (3C), and substrate cover diversity (3E), each of which correlated with all of the invertebrate metrics including the 10-metric score. Stream sinuosity, or meandering, provides more diverse habitat and refuge for invertebrates. It also is highly negatively correlated with urbanization. Buffer length is an indicator of the longitudinal extent of stream buffers and the number of gaps in buffer continuity (Rasmussen and others, 2009). Naturally vegetated buffers with minimal interruptions, such as bridges, stormwater entry points, and development, are associated with healthier streams (Walsh and others, 2005). The two substrate variables measure in-stream habitat characteristics and indicate the importance of in-stream conditions that in some instances may not be directly related to larger watershed factors. Substrate cover diversity describes the number and variety of habitat and cover types, including leaf packs, woody debris, root mats, and overhanging or inundated vegetation, which provide feeding and living locations for a diversity of organisms (Rasmussen and others 2009). Riffle substrate embeddedness is a measure of the amount of packed fine material surrounding rocks and other substrates. Generally, as rocks become embedded, the surface area and living space available to macroinvertebrates and fish decrease (Barbour, 1999). Correlation analysis indicated that if important riparian and in-stream habitat conditions improved, so might invertebrate communities and stream biological quality.

Invertebrate responses to urbanization in Johnson County (as indicated by percent impervious surface), when plotted using LOWESS smoothing, generally showed linear patterns rather than identifiable thresholds (fig. 14). Some early studies in other areas showed that biological conditions generally start to decline when impervious surface exceeds about 10 percent (Klein, 1979; Booth and Jackson, 1997; Paul and Meyer, 2001). Other studies indicate that impervious surface oversimplifies a more complex combination of factors affecting stream biology (Booth and others, 2004) and no threshold exists (Karr and Chu, 2000). The linear responses indicated in this study were consistent with results from a study of invertebrate responses to urban gradients in nine metropolitan areas (Cuffney 2010. and others, 2010), which determined that invertebrate assemblages begin to change at low levels of urbanization and usually follow a linear response as hypothesized by Booth and others (2004). Cuffney and others (2010) determined that streams in metropolitan areas that were converted from forest or grassland underwent more degradation of biological assemblages during urbanization than those converted from cropland or pasture. The authors suggested that the apparent lack of resistance to early phases of urbanization in many metropoli$\tan$ areas may be because biological communities already have been disturbed by changes associated with agriculture. This explanation may apply to watersheds in Johnson County.
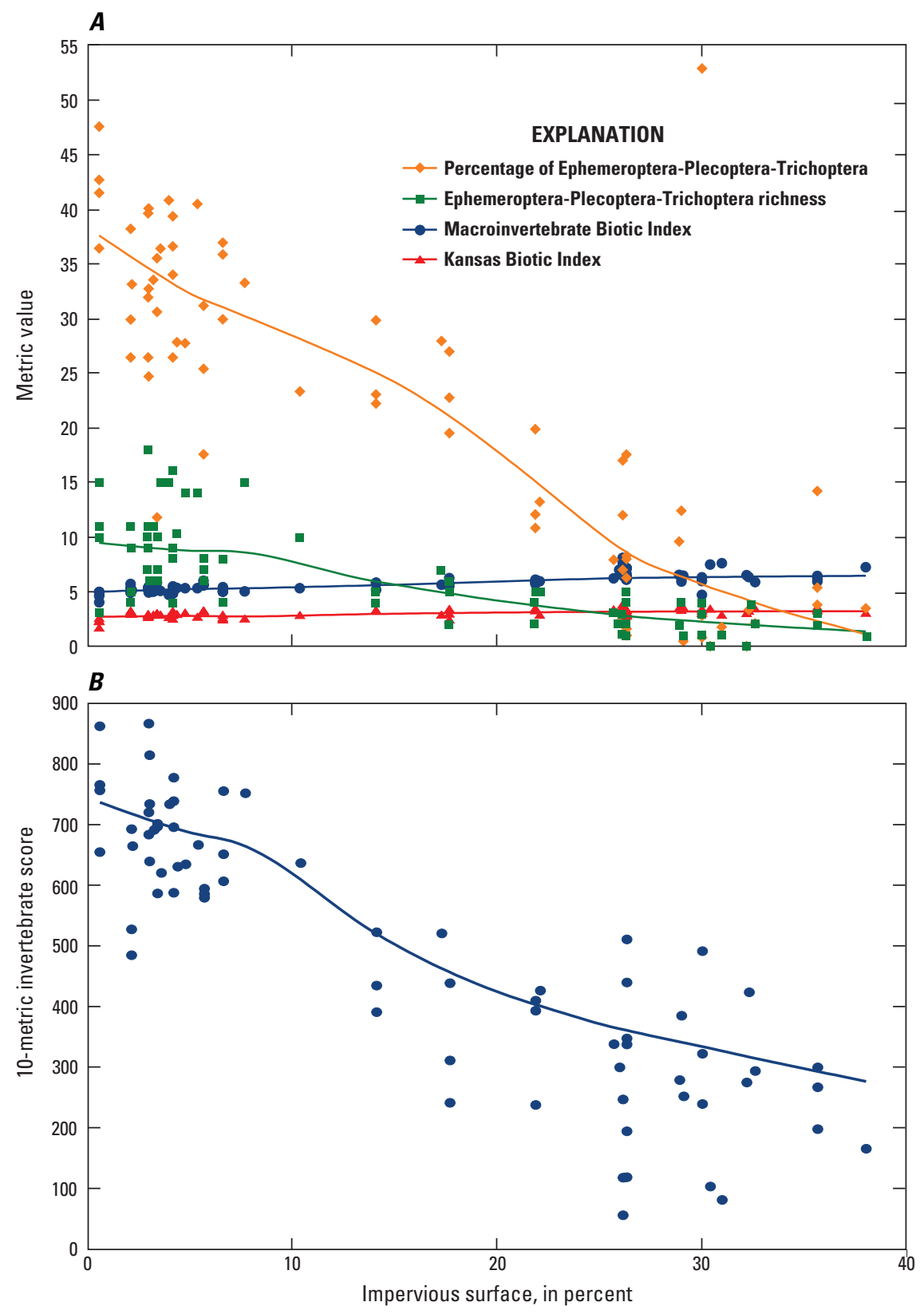

Figure 14. Invertebrate response patterns to urbanization as indicated by percent impervious surface at stream sites in Johnson County, Kansas, 2003, 2004, 2007, and 


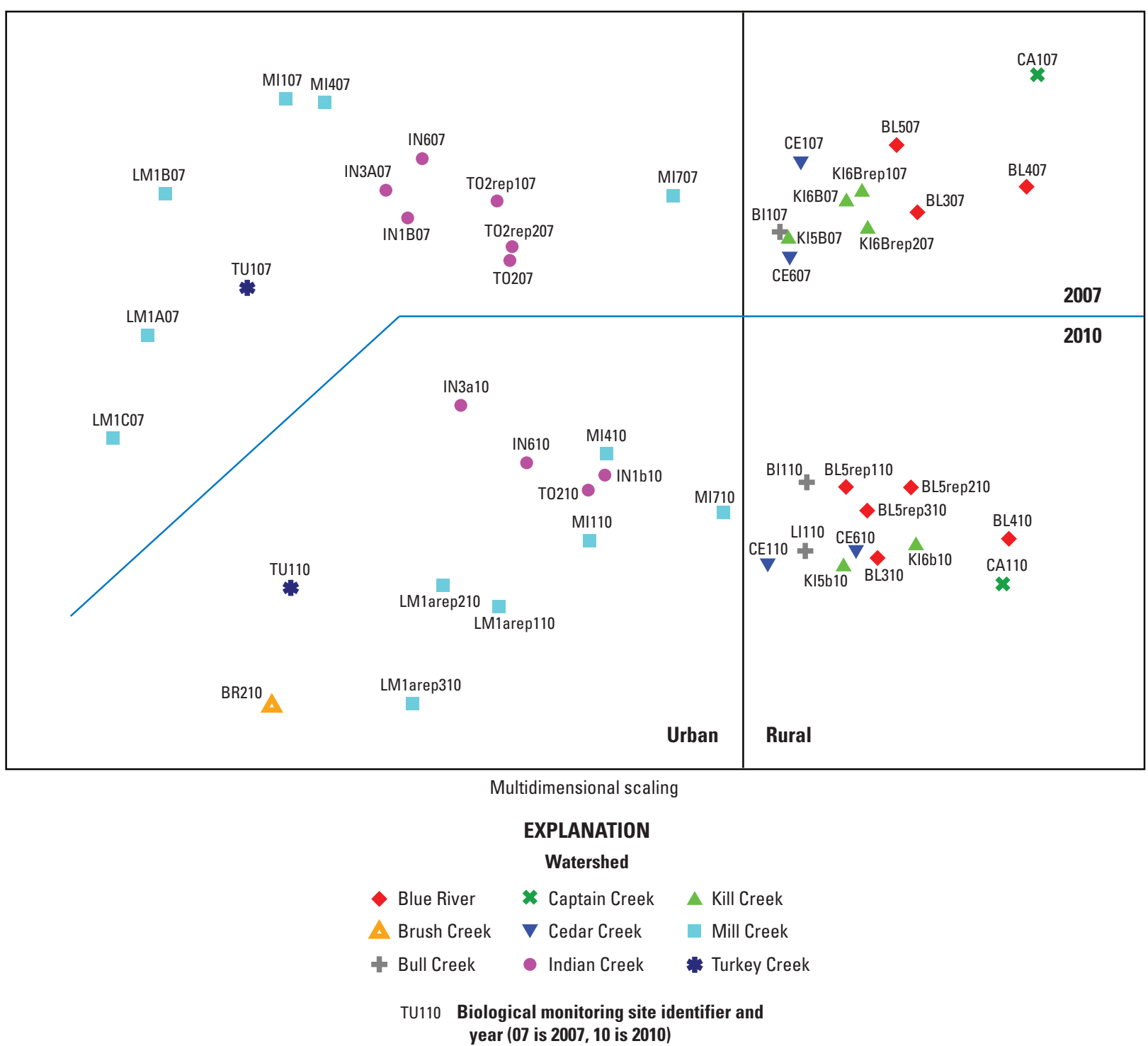

Figure 15. Multidimensional scaling of macroinvertebrate abundance at stream biological monitoring sites in Johnson County, Kansas, 2007, 2010.

Nonparametric multidimensional scaling (MDS) is an ordination technique used to represent complex biological relations accurately in a small dimensional space (Clarke and Warwick, 2005). MDS graphs, with axes that have no units, show relative likeness among monitoring sites. MDS graphs of macroinvertebrate abundance data generated using Primer software showed distinct separation of sites according to sample year and rural and urban land use (fig. 15). In 2010 sites were more tightly clustered than in 2007, indicating less overall variability among sites. For both years, variability among rural sites was smaller than among urban sites, as indicated by the smaller rural cluster. Sites in the Mill Creek watershed were most variable both years partly because it is the only watershed that includes headwater stream sites (LM1a in 2010, and LM1a, LM1b, and LM1c in 2007), which would be expected to differ from larger stream sites. In addition, the most downstream Mill Creek site (MI7) plots closely to rural sites indicating that macroinvertebrate assemblages are more similar to those at rural sites than urban sites. Although this site contains the smallest amount of urban land of the urban sites, urban land use is predominant at 68 percent.

Primer's BEST feature determined that 62 percent of the variance in macroinvertebrate communities was explained by the single environmental factor, percent impervious surface. The second best variable was specific conductance of water, but adding that variable only improved the percent of variance explained to 66 percent.

Multiple linear regression (MLR) models were developed for the four macroinvertebrate metrics used by KDHE to determine aquatic-life-support status (MBI, KBI-NO, EPT Richness, and Percent EPT). Although multiple environmental variables were considered as explanatory variables, including those describing land use, streamflow, water and streambedsediment chemistry, in-stream habitat, and riparian buffer 
conditions, only measures of urbanization (percent urban land use or impervious surface) were significant for each of the models. Percent impervious surface, as a measure of urban land use, was retained in each of the final models and explained 34 to 67 percent of the variability in biological communities (table 11, fig. 16A). In each model, biological quality as indicated by the metric decreases as impervious surface increases. Percent impervious surface explains 76 percent of the variability among sites in the 10-metric invertebrate scores (fig. 16B). Impervious surface is highly correlated with biological variables because increasing impervious surface area also increases contaminant-laden stormwater runoff that alters hydrology and stream chemistry (Brabec and others, 2002; Walsh and others, 2005). When measures of upstream urbanization were excluded from models in an attempt to isolate more specific contributing factors, only PAH concentration in streambed sediment or specific conductance of water were significant, individually. Since each of those variables is highly correlated with urban land use (table 10), they represent surrogates for urban land use rather than providing additional information about environmental variables that affect stream biological conditions.

Waite and others (2010) documented that land-use variables are the best predictors of stream biological condition, but that models were improved by including an additional natural variable such as mean annual precipitation or watershed slope. Since this study represents a small geographical area, the physiographic variability among sites may not have been large enough for such natural variables to distinguish among sites.

Results from this study indicate that the cumulative effects of urbanization negatively affect stream quality. Effects of urbanization on Johnson County streams are similar to effects described in national studies that assess effects of urbanization on stream ecology (Brown and others, 2009; Cuffney and others, 2010). Quantification of the primary environmental factors affecting stream quality is made difficult by the complexity of stream systems; however, results indicate that no small subset of environmental variables is causing stream degradation. Although multiple factors are correlated with stream degradation, general urbanization, as indicated by impervious surface area or urban land use, consistently is determined to be the fundamental factor causing change in streams. Individual important environmental factors such as nutrients in water and streambed sediment, specific conductance of water, PAHs in streambed sediment, and some riparian and in-stream habitat variables, serve as surrogates for urbanization and, collectively, contribute to stream impairments. Improvement in any single environmental factor is not likely to result in measurable changes in stream health; however, the cumulative effects of environmental improvements will lead to increasing biological quality.

Management practices that may be most important in protecting the health of streams in Johnson County are minimizing the effects of impervious surfaces, protection of stream corridors, and reduction of sediment, nutrients, and chemicals at their sources and along transport pathways. Healthy stream corridors provide hydrological and physical-habitat conditions to support healthy aquatic communities, as well as provide infiltration and natural filtering opportunities for stormwater runoff. Restoration and protection of riparian areas and wetlands is identified in the Kansas Water Plan (Kansas Water Office, 2009) and Kansas Nonpoint Source Pollution Plan (Kansas Department of Health and Environment, 2010c) as primary components in restoring and maintaining water quality to fully support designated uses. Reduction of sediment, nutrients, and chemicals at their sources (by reducing construction runoff, fertilizer application, and use of household chemicals, as examples) and along the transport pathways (using detention ponds and pervious pavements, for example) results in fewer contaminants requiring filtration and degradation within the riparian areas.

The stream biological monitoring program in Johnson County has made it possible to characterize stream health throughout Johnson County and during various hydrologic conditions, identify sites with the best and worst quality, determine environmental factors most closely related to stream health, and document stream conditions for future comparison and evaluation. Each additional year of data collection provides data under different conditions, identifies new and changing trends, and allows statistical analyses with more confidence. Collectively, this information leads to more informed decisionmaking and expenditure of resources directed toward maintaining healthy stream ecosystems.

Table 11. Multiple linear regression models for biological monitoring sites in Johnson County, Kansas based on data collected in 2003, 2004, 2007, and 2010.

[IMP, percent impervious surface upstream from sampling sites; MBI, macroinvertebrate biotic index; KBI-NO, Kansas biotic index; EPT, Ephemeroptera Plecoptera Trichoptera; $n$, number of values in sample set; $\mathrm{R}^{2}$, coefficient of determination; Adj $\mathrm{R}^{2}$, adjusted coefficient of determination; RMSE, root mean squared error; coefficients and intercepts are statistically significant at $p<0.05]$

\begin{tabular}{llcccl}
\hline \multicolumn{1}{c}{ Response variable } & \multicolumn{1}{c}{ Regression model } & $\mathbf{n}$ & $\mathbf{R}^{2}$ & Adj $^{2}$ & \multicolumn{1}{c}{ RMSE } \\
\hline MBI & $M B I=0.0504$ IMP +5.00 & 72 & 0.57 & 0.57 & 0.5346 \\
KBI-NO & KBI-NO $=0.0175 I M P+2.67$ & 72 & 0.34 & 0.34 & 0.2976 \\
EPT Richness & EPTRich $=-0.2734 I M P+10.35$ & 72 & 0.57 & 0.56 & 2.956 \\
Percent EPT & $p E P T=-0.9535 I M P+36.60$ & 72 & 0.67 & 0.67 & 8.253 \\
\hline
\end{tabular}



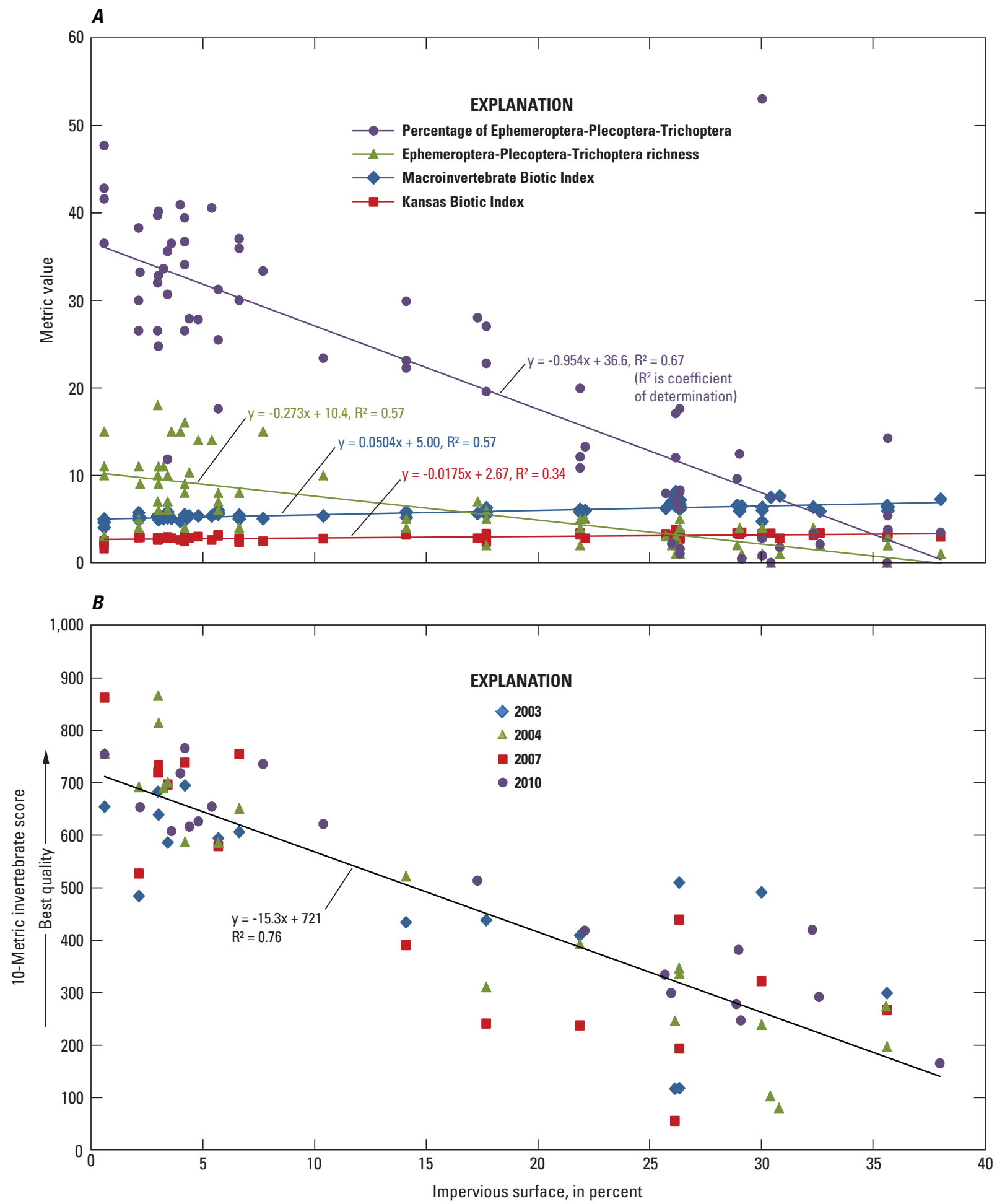

Figure 16. Selected macroinvertebrate metrics (y) plotted against impervious surface area $(x)$ in the watersheds upstream from biological monitoring sites in Johnson County, Kansas, 2003, 2004, 2007, and 2010. 


\section{Summary}

The purpose of this report is to assess the quality of streams throughout Johnson County from 2002-10. Aquatic biological communities and the environmental variables that may affect them are evaluated. Stream quality is characterized on the basis of watershed land use, streamflow, water and streambed-sediment chemistry, riparian habitat conditions, algal periphyton communities, and macroinvertebrate communities. Water chemistry data represent base-flow conditions only, and do not show the variability in concentrations that occurs during stormwater runoff. Data collected during 2010 are used to describe conditions at the end of the study period and to evaluate changing conditions by making comparisons to previously collected data. This report characterizes stream biological communities and physical and chemical conditions among stream sites and watersheds throughout the county, describes changes during the period 2002-10, evaluates conditions relative to Kansas Department of Health and Environment (KDHE) impairment categories and water-quality standards, and describes environmental factors that are most strongly correlated with biological stream quality.

Constituent concentrations in water during base flow varied across the study area and 2010 conditions were not markedly different from those measured previously (2003, 2004, and 2007). Generally the highest specific conductance, dissolved solids, and major ions in water occurred at urban sites except the upstream Cedar Creek site, which is rural and has a large area of commercial and industrial land less than 1 mile upstream on both sides of the creek. The highest baseflow nutrient concentrations in water occurred downstream from wastewater treatment facilities. Total nitrogen and total phosphorus were highest each year sampled at two Indian Creek sites that are most directly downstream from wastewater discharge, and at the first Mill Creek site downstream from wastewater discharge.

Constituent concentrations in streambed sediment also varied across the study area and some notable changes occurred from previously collected data. High total organic carbon and nutrient concentrations at the Big Bull Creek site in 2003 decreased to at least one-fourth of those concentrations in 2007 and 2010 likely because of the reduction in upstream wastewater discharge contributions. Trace metals were detected in streambed sediment from all sites. The highest concentrations of trace metals in 2010 occurred at sites on Mill and Indian Creeks. The highest concentrations of zinc occurred at two sites on Indian Creek with heavy bridge traffic. Some metals concentrations showed downward trends across the county from 2003 to 2010 . For example, nickel concentrations decreased by at least 20 percent at 6 of the 15 sites for which data were available in 2003, and increased at 1 site on Mill Creek. Zinc concentration at Indian Creek at State Line increased from $170 \mathrm{mg} / \mathrm{kg}$ in 2003 to $500 \mathrm{mg} / \mathrm{kg}$, exceeding the probable effects concentration (PEC) of $459 \mathrm{mg} / \mathrm{kg}$. Zinc was the only metal to exceed the PEC in 2010. In 2007, chromium and nickel at the upstream Cedar
Creek site exceeded PECs, and in 2003, no metals exceeded PECs.

Of 72 organic compounds analyzed in streambed sediment, 26 were detected including pesticides, polycyclic aromatic hydrocarbons (PAHs), fuel products, fragrances, preservatives, plasticizers, manufacturing byproducts, flame retardants, and disinfectants. All 6 PAH compounds analyzed were detected, and PECs for 4 of the 6 PAH compounds analyzed were exceeded in 2010, in some instances by as much as 14 times. Higher PAH concentrations in 2010 may have resulted from more stormwater runoff immediately preceding sample collection. Only five pesticide compounds were detected in streambed sediment, including carbazole and four pyrethroid compounds. At least one pyrethroid compound was detected at six sites including three urban sites and three rural sites. Of the eight detections at the six sites, chronic toxicity guidelines were exceeded at five sites. At the Big Bull Creek site (BI1) about 70 percent of the detected constituents in 2003 decreased by at least 20 percent in 2010 .

Total habitat scores from 2010 were suboptimal at 17 of the 20 monitoring sites and marginal at the remaining sites. The variability of habitat scores among sites was small. The lowest habitat scores, corresponding with the poorest habitat condition, occurred at the three most urbanized sites, in part, because of poor riparian buffer conditions. The highest total habitat scores indicating the best habitat condition occurred at rural sites.

Biological quality at nearly all monitoring sites showed some level of impairment. The four most common periphyton taxa in samples from 2010 were taxa that were identified previously as generally indicative of eutrophic conditions. Six of the 20 sites sampled had periphyton chlorophyll concentrations above the defined nuisance threshold in 2010, and 4 of 11 sites exceeded the threshold in 2007. Moreover, periphyton chlorophyll concentration and biomass were significantly higher at rural sites than at urban sites.

Most macroinvertebrate communities metrics reflected a gradient in land use in which the less disturbed streams were located in rural areas of Johnson County. Macroinvertebrate Biotic Index (MBI) is one of four invertebrate metrics used by the KDHE to determine aquatic life support. None of the sites met the KDHE criteria for full support of aquatic life based on MBI scores, and all urban sites were nonsupporting of aquatic life. The Mill Creek TMDL for biological impairment establishes a MBI goal of 4.5 or less as an average for 2006-2015. MBI values for monitoring sites in the Mill Creek watershed have thus far failed to achieve the goal; scores ranged from 5.64 to 6.36 in 2010, showing no improvement from a range of 4.71 to 7.63 in previous years.

Four sites (about 19 percent) in 2010 were fully supporting of aquatic life on the basis of the four metrics used by KDHE to categorize sites. This is a notable difference compared to previous years when no sites were fully supporting (in 2003 and 2004) or just one site was fully supporting (in 2007). About 29 percent of the sites were partially supporting of aquatic life in 2010 and about 52 percent of the sites were 
nonsupporting of aquatic life. All nonsupporting sites were in urbanized watersheds.

Multimetric scores, developed by integrating 10 selected metrics into 1 overall score as a relative indicator of the biological quality of Johnson County streams, indicated that the 4 sites with the poorest scores were urban sites on Turkey, Indian, and headwater Mill Creeks, and the 4 sites with the best scores were rural sites on the Blue River, and Cedar, Captain, and Kill Creeks. Two of the best sites are affected by upstream wastewater discharges.

Based on general categories of relative disturbance, seven sites in the rural western and southern parts of the County were least affected by disturbance and showed no change from 2003 to 2010. The two most urban sites in northeastern Johnson County were most affected by human disturbance and also showed no change from 2003 to 2010 . Two rural sites showed improvements since 2004, including the Big Bull Creek site where wastewater discharges were reduced in 2007. Improvement in biological communities at these sites is consistent with improvement in streambed-sediment quality at the same two sites.

Considering data collected from 2003, 2004, 2007, and 2010 , environmental variables that consistently were highly correlated with biological variables were impervious surface area and urban land use. In addition, density of stormwater entry points adjacent to streams was significantly negatively correlated with biological conditions. Specific conductance of water and sum of polycyclic aromatic hydrocarbon (PAH) concentrations in streambed sediment were significantly negatively correlated with biological conditions. Both of those constituents also were highly correlated with the land-use variables and, therefore, likely are redundant indicators of urbanization. Total nitrogen in water and total phosphorus in streambed sediment also were negatively correlated with most of the invertebrate variables, which is a notable difference from previous analyses using smaller datasets when nutrient relations were weak or not detected. The total habitat score was strongly correlated with the 10-metric macroinvertebrate score and with most of the individual metrics. The most important habitat variables, each of which correlated with all of the favorable invertebrate metrics including the 10-metric score, were sinuosity (positive), buffer length (positive), riffle substrate embeddedness (negative), and substrate cover diversity (positive). Density of stormwater entry points was significantly negatively correlated with all biological conditions indicated by macroinvertebrate metrics. Correlation analysis indicated that as important riparian and in-stream habitat conditions improve, so might invertebrate communities and stream biological quality. Invertebrate responses to urbanization in Johnson County showed linear patterns rather than identifiable thresholds.

Primer's BEST feature determined that 62 percent of the variance in macroinvertebrate communities was explained by the single environmental factor, percent impervious surface. Including the next best variable identified by BEST, specific conductance of water, did not substantially improve the percent of variance explained. Multiple linear regression models developed for each of the four macroinvertebrate metrics used to determine aquatic-life-support status (MBI, KBINO, EPT Richness, and Percent EPT) indicated that percent impervious surface, as a measure of urban land use, explained 34 to 67 percent of the variability in biological communities metrics.

The cumulative effects of urbanization negatively affect the quality of Johnson County streams. Effects of urbanization on Johnson County streams are similar to effects described in national studies that assess effects of urbanization on stream health. Results indicate that multiple factors are correlated with stream degradation; however, general urbanization, as indicated by impervious surface area or urban land use, consistently is determined to be the fundamental factor causing change in streams. Individual important environmental factors such as specific conductance of water, PAHs in streambed sediment, in-stream habitat, and riparian buffer conditions, serve as surrogates for urbanization and, collectively, contribute to stream impairments. Improvement in any single environmental factor is not likely to result in a measurable change in stream health; however, the cumulative effects of environmental improvements will lead to increasing biological quality. Management practices that may be most important in protecting health of streams in Johnson County are minimizing effects of impervious surface, protecting stream corridors, and reducing sediment, nutrients, and chemicals at their sources and along transport pathways.

The stream biological monitoring program in Johnson County has made it possible to characterize stream health throughout the county and during various hydrologic conditions, identify sites with the best and worst quality, determine environmental factors most closely related to stream health, and document stream conditions for future comparison and evaluation. Each additional year of data collection provides data under different conditions, identifies new and changing trends, and allows statistical analyses with more confidence. Collectively, this information leads to more informed decisionmaking and expenditure of resources directed toward maintaining healthy stream ecosystems. 


\section{References Cited}

Allan, J.D., 1995, Stream ecology-structure and function of running waters: Boston, Massachusetts, Kluwer Academic Publishers, 388 p.

American Public Health Association, American Water Works Association, and Water Environment Federation, 1995, Standard methods for the examination of water and wastewater (19th ed.): Washington, D.C., American Public Health Association, $905 \mathrm{p}$.

Angelo, R.T., Knight, G.L., Olsen, K.T., and Stiles, T.C., 2010, Kansas reference streams-Selection of suitable candidates, impending threats to reference stature, and recommendations for long-term conservation: Kansas Department of Health and Environment, $40 \mathrm{p}$.

Arar, E.J., and Collins, G.B., 1997, U.S. Environmental Protection Agency Method 445.0, In vitro determination of chlorophyll- $a$ and pheophytin $a$ in marine and freshwater algae by fluorescence, Revision 1.2: Office of Research and Development, $22 \mathrm{p}$.

Bahls, L.L., 1973, Diatom community response to primary wastewater effluent: Journal of the Water Pollution Control Federation, v. 45, p. 134-144.

Bahls, L.L., 1993, Periphyton bioassessment methods for Montana streams: Water Quality Bureau, Department of Health and Environmental Sciences, 69 p.

Barbour, M.T., Gerritsen, J., Griffith, G.E., Frydenborg, R., McCarron, E., White, J.S., and Bastian, M.L., 1996, A framework for biological criteria for Florida streams using benthic macroinvertebrates: Journal of the North American Benthological Society, v. 15, p. 185-211.

Barbour, M.T., Gerritsen, J., Snyder, B.D., and Stribling, J.B., 1999, Rapid bioassessment protocols for use in streams and wadeable rivers - Periphyton, benthic macroinvertebrates, and fish (2d ed.): U.S. Environmental Protection Agency Report, EPA 841/B-99/002, 18 p.

Black, R.W., Moran, P.W., and Frankforter, J.D., 2011, Response of algal metrics to nutrients and physical factors and identification of nutrient thresholds in agricultural streams: Environmental Monitoring Assessment, v. 175, no. $1-4$, p. $397-417$.

Booth, D., and Jackson, C.R., 1997, Urbanization of aquatic systems - Degradation thresholds, stormwater detection, and the limits of mitigation: Journal of American Water Resources Association, v. 33, no. 5, p. 1077-1090.
Booth, D.B., Karr, J.R., Schauman, S., Konrad, P., Morley, S.A., Larson, M.G., and Burges, S.J., 2004, Reviving urban streams - Land use, hydrology, biology, and human behavior: Journal of the American Water Resources Association, v. 40 , p. 1351-1364.

Brabec, E., Schulte, S., and Richards, P.L., 2002, Impervious surfaces and water quality - A review of current literature and its implications for watershed planning: Journal of Planning Literature, v. 16, p. 499-514.

Brower, J.E., Zar, J.H., and von Ende, C.N., 1998, Field and laboratory methods for general ecology (4th ed.): Dubuque, Iowa, Wm. C. Brown Publishers, 237 p.

Brown, B.J., and Olive, J.H., 1995, Diatom communities in the Cuyahoga River (USA) — Changes in species composition between 1974 and 1992 following renovations in wastewater management: Ohio Journal of Science, v. 95, p. 254-260.

Brown, L.R., Cuffney, T.E., Coles, J.F., Fitzpatrick, F., McMahon, G., Steuer, J., Bell, A.H., and May, J.T., 2009, Urban streams across the USA-Lessons learned from studies in 9 metropolitan areas: Journal of the North American Benthological Society, v. 28, no. 4, p. 1051-1069.

Burkhardt, M.R., Zaugg, S.D., Smith, S.G., and ReVello, R.C., 2006, Determination of wastewater compounds in sediment and soil by pressurized solvent extraction, solid-phase extraction, and capillary-column gas chromatography/ mass spectrometry: U.S. Geological Survey Techniques and Methods, book 5, chap. B2, 40 p.

Calhoun, D.L., Gregory, M.B., and Weyers, H.S., 2008, Algal and invertebrate community composition along agricultural gradients - A comparative study from two regions of the eastern United States: U.S. Geological Survey Scientific Investigations Report 2008-5046, 33 p.

Carter, J.L., Resh, V.H., Hannaford, M.J., and Myers, M.J., 2007, Macroinvertebrates as biotic indicators of environmental quality, in Hauer, F.R., and Lamberti, G.A., eds., Methods in stream ecology (2d ed.): Burlington, Mass., Academic Press, p. 785-804.

Childress, C.J.O., Foreman, W.T., Connor, B.F., and Maloney, T.J., 1999, New reporting procedures based on longterm method detection levels and some considerations for interpretations of water-quality data provided by the U.S. Geological Survey National Water Quality Laboratory: U.S. Geological Survey Open-File Report 99-193, 19 p.

Christensen, A.M., Nakajima, F., and Baun, A., 2006, Toxicity of water and sediment in a small urban river: Environmental Pollution, v. 144, p. 621-625. 
Clarke, K.R., and Ainsworth, M., 1993, A method of linking multivariate community structure to environmental variables: Marine Ecological Progress Series, v. 92, p. 205-219.

Clarke, K.R., and Gorley, R.N., 2006, PRIMER version 6 user manual-Plymouth routines in multivariate ecological research: Plymouth, United Kingdom, PRIMER-E, Ltd., $190 \mathrm{p}$.

Clarke, K.R., and Warwick, R.M., 2005, Change in marine communities - An approach to statistical analysis and interpretation (2d ed.): Plymouth, United Kingdom, Primer-E, Ltd., 172 p.

Cooper, C.M., 1993, Biological effects of agriculturally derived surface water pollutants on aquatic systems-A review: Journal of Environmental Quality, v. 22, no. 3, p. 402-408.

Corsi, S.R., Graczyk, D.J., Geis, S.W., Booth, N.L., and Richards, K.D., 2010, A fresh look at road salt-Aquatic toxicity and water-quality impacts on local, regional and national scales: Environmental Science and Technology, v. 44, no. 19 , p. 7376-7382.

Cuffney, T.F., 2003, User's manual for the National WaterQuality Assessment Program Invertebrate Data Analysis System (IDAS) software, ver. 3: U.S. Geological Survey Open File Report 03-172, 103 p.

Cuffney, T.F., Brightbill, R.A., May, J.T., and Waite, I.R., 2010, Responses of benthic macroinvertebrates to environmental changes associated with urbanization in nine metropolitan areas: Ecological Applications, v. 20, no. 5, p. 1384-1401.

Cuffney, T.F., and Brightbill, R.A., 2011, User's manual for the National Water-Quality Assessment Program Invertebrate Data Analysis System (IDAS) software, ver. 5: U.S. Geological Survey Techniques and Methods 7-C4, $126 \mathrm{p}$. (Also available at http://pubs.usgs.gov/tm/7c4/.)

Cummins, K.W., 1973, Trophic relations of aquatic insects: Annual Review of Entomology, v. 18, p. 361-386.

Davenport, T.E., and Kelly, M.H., 1983, Water resource data and preliminary trend analysis for the Highland Silver Lake Monitoring and Evaluation Project, Madison County, Illinois, phase II: Springfield, Illinois Environmental Protection Agency, Report No. IEPA/WPC/83-013, various pagination.

Davies, S.P., and Jackson, S.K., 2006, The biological condition gradient - a conceptual model for interpreting detrimental change in aquatic ecosystems: Ecological Applications, v. 16 , no. 4 , p. 1251-1266.

Delwiche, L.D., and Slaughter, S.J., 1998, The little SAS book-A primer: Cary, North Carolina, SAS Institute, Inc., $228 \mathrm{p}$.
DeShon, J.E., 1995, Development and application of the Invertebrate Community Index (ICI), in Davis, W.S., and Simon, T.P., eds., Biological assessment and criteria-tools for water resource planning and decision making: Boca Raton, Florida, Lewis Publishers, p. 217-243.

ETC, Institute, 2009, 2009 Regional water quality survey final report, conducted for the Mid-America Regional Council, accessed April 2012, at http://marc.org/Environment/Water/ $p d f_{s} / 2009$ Survey.pdf.

Feminella, J.W., 1996, Comparison of benthic macroinvertebrate assemblages in small streams along a gradient of flow permanence: Journal of the North American Benthological Society, v. 15, no. 4, p. 651-669.

Fishman, M.J., and Friedman, L.C., 1989, Methods for determination of inorganic substances in water and fluvial sediments: U.S. Geological Survey Techniques of WaterResources Investigations, book 5, chap. A1, 545 p.

Fitzpatrick, F.A., Waite, I.R., D’Arconte, P.J., Meador, M.R., Maputin, M.A., and Gurtz, M.E., 1998, Revised methods for characterizing stream habitat in the National Water Quality Assessment Program: U.S. Geological Survey Water-Resources Investigations Report 09-4052, 67 p.

Foreman, W.T., Connor, B.F., Furlong, E.T., Vaught, D.G., and Merten, L.M., 1995, Methods of analysis by the U.S. Geological Survey National Water Quality Laboratory-determination of organochlorine pesticides and polychlorinated byphenyls in bottom sediment by dual capillary column gas chromatography with electron-capture detection: U.S. Geological Survey Open-File Report 95-140, 78 p.

Fry, J., Xian, G., Jin, S., Dewitz, J., Homer, C., Yang, L., Barnes, C., Herold, N., and Wickham, J., 2011, Completion of the 2006 National Land Cover Database for the Conterminous United States: Photogrammetric Engineering \& Remote Sensing, v. 77, no. 9, p. 858-864.

Graham, J.L., Loftin, K.A., Ziegler, A.C., and Meyer, M.T., 2008, Cyanobacteria in lakes and reservoirs - toxin and taste-and-odor sampling guidelines (ver 1.0): U.S. Geological Survey Techniques of Water-Resources Investigations, book 9, chap. A7, sec. 7.5.

Graham, J.L., Stone, M.L., Rasmussen, T.J., and Poulton, B.C., 2010, Effects of wastewater effluent discharge and treatment facility upgrades on environmental and biological conditions of the Upper Blue River, Johnson County, Kansas and Jackson County, Missouri, January 2003 through March 2009: U.S. Geological Survey Scientific Investigations Report 2010-5248, 85 p.

Guy, H.P., 1969, Laboratory theory and methods for sediment analysis: U.S. Geological Survey Techniques of WaterResources Investigations, book 5, chap. C1, $58 \mathrm{p}$. 
Hambrook-Berkman, J.A., and Canova, M.G., 2007, Algal biomass indicators: U.S. Geological Survey Techniques of Water-Resources Investigations, book 9, chap. A7, sec. 7.4, accessed March 2011, at http://pubs.water.usgs. gov/twri9A7.

Helsel, D.R., and Hirsch, R.M., 2002, Statistical methods in water resources-Hydrologic analysis and interpretation: Techniques of Water-Resources Investigations, book 4, chap. A3, 510 p.

Hem, J.D., 1992, Study and interpretation of chemical characteristics of natural water ( $3 \mathrm{~d}$ ed.): U.S. Geological Survey Water-Supply Paper 2254, 263 p.

Hession, W.C., Pizuto, J.E., Johnson, T.E., and Horwitz, R.J., 2003, Influence of bank vegetation on channel morphology in rural and urban watersheds: Geology, v. 31, p. 147-150.

Hill, I.R., 1989, Aquatic organisms and pyrethroids: Pesticide Science, v. 27, p. 429-465.

Hillebrand, H., Duerselen, C.D., Kirschtel, D.B., Pollingher, U., and Zohary, T., 1999, Biovolume calculation for pelagic and benthic microalgae: Journal of Phycology, v. 35, p. $403-424$.

Hladik, M.L. and Kuivila, K.M., 2012, Pyrethroid insecticides in bed sediments from urban and agricultural stream across the United States: Journal of Environmental Monitoring, v.14, p. $1838-1845$.

Hladik, M.L., Smalling, K.L., and Kuivila, K.M., 2009, Methods of analysis - determination of pyrethroid insecticides in water and sediment using gas chromatography/mass spectrometry: U.S. Geological Survey Techniques and Methods, book 5 , chap. C2, 18 p.

Horner, R.R., Welch, E.B., and Veenstra, R.B., 1983, Development of nuisance periphytic algae in laboratory streams in relation to enrichment and velocity, in Wetzel, R.G., ed., Periphyton of Freshwater Ecosystems: The Hague, The Netherlands, Dr. W. Junk Publishers, p. 121-131.

Horowitz, R.J., 1978, Temporal variability patterns and the distributional patterns of fishes: Ecological Monographs, v. 48 , p. $30-321$.

Horowitz, A.J., 1991, A primer on sediment trace element chemistry, 2d ed.: Lewis Publishers, Chelsea, MI.

Horowitz, A.J., Elrick, K.A., and Smith J.J., 2001, Estimating suspended sediment and trace element fluxes in large river basins-Methodological considerations as applied to the NASQAN program: Hydrological Processes, v. 15, no. 7 , p. 1169-1208.

Huggins, D.G., and Moffett, M.F., 1988, Proposed biotic and habitat indices for use in Kansas streams: Lawrence, Kansas Biological Survey, Report 35, 183 p.
Kansas Department of Health and Environment, 2000, Division of environment quality management Plan, part IIIStream biological monitoring program, quality assurance management plan: Topeka, Kansas, Bureau of Environmental Field Services, Technical Services section, 42 p.

Kansas Department of Health and Environment, 2005, Kansas Administrative Regulations (KAR), Title 28, Article 16, Surface water quality standards: Topeka, Kansas, accessed January 2012, at http://www.kdheks.gov/water/download/ kwqs_plus_supporting.pdf.

Kansas Department of Health and Environment, 2004, Surface water nutrient reduction plan: Topeka, Kansas, Bureau of Water, $47 \mathrm{p}$.

Kansas Department of Health and Environment, 2006, Kansas-Lower Republican Basin total maximum daily load, waterbody-Mill Creek watershed, water quality impairment-biology: accessed February 2011, at http://www. kdheks.gov/tmdl/2006/new_mill_creek_bio_tmdl.pdf.

Kansas Department of Health and Environment, 2010a, Kansas integrated water quality assessment: accessed June 2009, at http://www.kdheks.gov/befs/ download/2008IR_040108FINAL.pdf.

Kansas Department of Health and Environment, 2010b, Kansas 2010 303(d) list of impaired waters: accessed February 2011, at http://www.kdheks.gov/tmdl/methodology.htm.

Kansas Department of Health and Environment, 2010c, Kansas nonpoint source pollution management plan 2010 update, accessed November 2011, at http://www.kdheks.gov/ nps/resources/KSNPSMgmtPlan_04-29-2011_final.pdf.

Kansas Applied Remote Sensing, 2006, Kansas Land Cover Patterns, accessed August 2012 at http://www.kars.ku.edu/ research/2005-kansas-land-cover-patterns-level-iv/.

Kansas Water Office, 2009, Kansas water plan, accessed November 2011, at http://www.kwo.org/Kansas_Water Plan/Kansas_Water_Plan.htm.

Karickhoff, S.W., 1984, Organic pollutant sorption in aquatic systems: Journal of Hydraulic Engineering, v. 110, no. 6, p. 707-735.

Karr, J.R., Fausch, K.D., Angermeier, P.L., Yant, P.R., and Schlosser, L.J., 1986, Assessing biological integrity in running waters - A method and its rationale: Illinois Natural History Survey, Special Publication 5, 28 p.

Karr, J.R., and Chu, E.W., 2000, Sustaining living rivers: Hydrobiologia, v. 422/423, p. 1-14.

Kentucky Division of Water, 1993, Methods for assessing biological integrity of surface waters: Frankfurt, Kentucky, Kentucky Department of Environmental Protection, 182 p. 
Kerans, B.L., and J.R. Karr, 1994, A benthic index of biotic integrity (B-IBI) for rivers of the Tennessee Valley: Ecology Applications, v. 4, no. 4, p. 768-785.

Klein, R., 1979, Urbanization and stream quality impairment: Water Resources Bulletin, no. 15, p. 948-963.

Klemm, D.J., Lewis, P.A., Fulk, F., and Lazorchak, J. M., 1990, Macroinvertebrate field and laboratory methods for evaluating the biological integrity of surface waters: Environmental Monitoring Series, USEPA-ORD, EPA/600/490/030.

Knowlton, M.F., 1984, Flow-through microcuvette for fluorometric determination of chlorophyll: Water Resources Bulletin, v. 20, p. 1198-1205.

Kolkwitz, R., and Marsson, M., 1908, Oekologie der pflanzlichen Saprobien: Berichte der Deutschen botanischen Gesellschaft, v. 26, p. 505-519.

Konrad, C.P., and Booth, D.B., 2005, Hydrologic changes in urban streams and their ecological significance: American Fisheries Society Symposium, v. 47, p. 157-177.

Konrad, C.P., Brasher, A.M.D., and May, J.T., 2008, Assessing streamflow characteristics as limiting factors on benthic invertebrate assemblages in streams across the western United States: Freshwater Biology, v. 53, no. 10 , p. 1983-1998.

Kutka, F.J., and Richards, C., 1996, Relating diatom assemblage structure to stream habitat quality: Journal of the North American Benthological Society, v. 15, no. 4, p. 469-480.

Lee, C.J., Mau, D.P., Rasmussen, T.J., 2005, Effects of point and nonpoint sources on water quality and relation to land use in Johnson County, northeastern Kansas, October 2002 through June 2004: U.S. Geological Survey Scientific Investigations Report 2005-5144, 104 p.

Lenat, D.L., 1993, A biotic index for the southeastern United States - derivation and list of tolerance values, with criteria for assigning water-quality ratings - 1993: Journal of the North American Benthological Society, v. 12, p. 279-290.

Leopold, L.B., 1968, Hydrology for urban planning-A guidebook on the hydrologic effects of urban land use: U.S. Geological Survey Circular 554, 18 p.

Lowe, R.L., and Pan, Y., 1996, Benthic algal communities as biological monitors, in Stevenson, R.J., Bothwell, M.L., and Lowe, R.L., eds., Algal ecology: San Diego, California, Academic Press, p. 705-739.
MacDonald, D.D., Ingersoll, C.G., and Berger, T.A., 2000, Development and evaluation of consensus-based sediment quality guidelines for freshwater ecosystems: Archives of Environmental Contamination and Toxicology, v. 39, p. 20-31.

Mahler, B.J., Van Metre, P.C., Bashara, T.J., Wilson, J.T., and Johns, D.A., 2005, Parking lot sealant-An unrecognized source of urban polycyclic aromatic hydrocarbons: Environmental Science and Technology, v. 39, p. 5560-5566.

McNabb, C.D., 1960, Enumeration of freshwater phytoplankton concentrated on the membrane filter: Limnology and Oceanography, v. 5, no. 1, p. 57-61.

Moran, P.W., Calhoun, D.L., Nowell, L.H., Kemble, N.E., Ingersoll, C.G., Hladik, M.L., Kuivila, K.M., Falcone, J.A., and Gilliom, R.J., 2012, Contaminants in stream sediments from seven U.S. metropolitan areas-Data summary of a National Pilot Study: U.S. Geological Survey Scientific Investigations Report 2011-5092, 66 p.

Moulton, S.R. II, Kennen, J.G., Goldstein, R.M., Hambrook, J.A., 2002, Revised protocols for sampling algal, invertebrate, and fish communities as part of the National WaterQuality Assessment Program: U.S. Geological Survey Open-File Report 02-150, 75 p.

Moulton, S.R., II, Carter, J.L., Grotheer, S.A., Cuffney, T.F., and Short, T.M., 2000, Methods of analysis by the U.S. Geological Survey national Water Quality Laboratory-Processing, taxonomy, and quality control of benthic macroinvertebrate samples: U.S. Geological Survey Open-File Report 2000-212, 49 p.

National Oceanic and Atmospheric Administration, 2011, National Climatic Data Center database, accessed September 26, 2011, at http://www.ncdc.noaa.gov/oa/ncdc.html.

Oklahoma Conservation Commission, 1993, Development of rapid bioassessment protocols for Oklahoma utilizing characteristics of the diatom community: Oklahoma City, Oklahoma, Oklahoma Conservation Commission, 104 p.

Ostendorf, D.W., Peeling, D.C., Mitchell, T.J., and Pollock, S.J., 2001, Chloride persistence in a deiced access road drainage system: Journal of Environmental Quality, v. 30, p. $1756-1770$.

Paul, M.J., and Meyer, J.L., 2001, Streams in the urban landscape: Annual Review of Ecology and Systematics, v. 32, p. 333-365.

Patrick Center for Environmental Research, 1988, Diatom cleaning by nitric acid digestion: The Academy of Natural Sciences of Philadelphia, Protocol No. P-13-02, 39 p. 
Perry, C.A., Wolock, D.M., and Artman, J.A., 2004, Estimates of flow duration, mean flow, and peak-discharge frequency values for Kansas stream locations: U.S. Geological Survey Scientific Investigations Report 2004-5033, 219 p. (Database available at $h t t p: / / k s . w a t e r . u s g s . g o v / s t u d i e s / s t r m s t a t s /$.

Peterson, D.L., Whistler, J.L., Egbert, S.L., and Martinko, E.A., 2010, 2005 Kansas land cover patterns phase II Final Report, KBS Report \#167: Kansas Biological Survey, University of Kansas, 49 p.

Poff, N.L., and Ward, J.V., 1989, Implications of streamflow variability and predictability for lotic community structurea regional analysis of streamflow patterns: Canadian Journal of Fisheries and Aquatic Sciences, v. 46, p. 1805-1818.

Pope, L.M., 2005, Assessment of contaminated streambed sediment in the Kansas part of the historic tri-state lead and zinc mining district, Cherokee County, 2004: U.S. Geological Survey Scientific Investigations Report 2005-5251, $61 \mathrm{p}$.

Porter, S.D., 2008, Algal attributes-An autecological classification of taxa collected by the National Water-Quality Assessment Program: U.S. Geological Survey Data Series 329, accessed February 2011, at http://pubs.usgs.gov/ds/ ds 329 .

Porter, S.D., Mueller, D.K., Spahr, N.E., Munn, M.D., and Dubrovsky, N.M., 2008, Efficacy of algal metrics for assessing nutrient and organic enrichment in flowing waters: Freshwater Biology, v. 53, p. 1036-1054.

Poulton, B.C., Rasmussen, T.J., and Lee, C.J., 2007, Assessment of biological conditions at selected stream sites in Johnson County, Kansas, and Cass and Jackson Counties, Missouri, 2003 and 2004: U.S. Geological Survey Scientific Investigations Report 2007-5108, 68 p.

Radtke, D.B., 2005, Bottom-material samples: U.S Geological Survey Techniques of Water-Resources Investigations, | book 9, chap. A8, accessed April 2011, at http://pubs.water. usgs.gov/twri9A8/.

Rasmussen, T.J., Poulton, B.C., and Graham, J.L., 2009, Quality of streams in Johnson County, Kansas, and relations to environmental variables, 2003-07: U.S. Geological Survey Scientific Investigations Report 2009-5235, 95 p.

Rasmussen, T.J., Lee, C.J., and Ziegler, A.C., 2008, Estimation of constituent concentrations, densities, loads, and yields in streams of Johnson County, northeastern Kansas, using regression models and continuous water-quality monitoring, October 2002 through December 2006: U.S. Geological Survey Scientific Investigations Report 2008-5014, 103 p.

Richter, B.D., Baumgartner, J.V., Powell, J., and Braun, D.P., 1996, A method for assessing hydrologic alteration within ecosystems: Conservation Biology, v. 10, p. 1163-1174.
Rosenberg, D.M., and Resh, V.H., 1993, Introduction to freshwater biomonitoring and benthic macroinvertebrates, in Rosenberg, D.M., and Resh, V.H., eds., Freshwater biomonitoring and benthic macroinvertebrates: New York, Chapman and Hall, Inc., p. 1-9.

Sartory, D.P., and Grobbelar, J.U., 1986, Extraction of chlorophyll- $a$ from freshwater phytoplankton for spectrophotometric analysis: Hydrobiologia, v. 114, p. 117-187.

Seaber, P.R., Kapinos, F.P., and Knapp, G.L., 1987, Hydrologic Unit Maps: U.S. Geological Survey Water-Supply Paper 2294, 63 p. (Also available at $h t t p: / / w a t e r . u s g s . g o v /$ GIS/huc.html.)

Sokal, R.R., and Rohlf, F.J., 1995, Biometry-The principles and practice of statistics in biological research ( $3 \mathrm{~d}$ ed.): New York, W.H. Freeman and Company, 887 p.

Sponseller, R.A., Benfield, E.F., and Valett, H.M., 2001, Relationships between land use, spatial scale and stream macroinvertebrate communities: Freshwater Biology, v. 46 no. 10, p. $1409-1424$.

Stewart, D.W., Rea, A.H., and Wolock, D.M., 2006, USGS streamgages linked to the medium resolution NHD: U.S. Geological Survey Data Series 195, accessed September 2011, at http://water.usgs.gov/GIS/metadata/usgswrd/XML/ streamgages.xml.

Stevenson, R.J., 1997, Scale-dependent determinants and consequences of benthic algal heterogeneity: Journal of the North American Benthological Society, v. 16, no. 1, p. 248-262.

Stevenson, R.J., and Rollins, S.L., 2007, Ecological assessments with benthic algae, in Hauer, F.R., and Lamberti, G.A., eds., Methods in stream ecology ( $2 \mathrm{~d}$ ed.): Burlington, Mass., Academic Press, p. 785-804, 877 p.

Stevenson, R.J., and Bahls, L.L., 1999, Periphyton protocols, in Barbour, M.T., Gerritson, J., Snyder, B.D., and Stribling, J.B., eds., Rapid bioassessment protocols for use in streams and wadeable rivers-Periphyton, benthic macroinvertebrates, and fish $(2 \mathrm{~d}$ ed.): Washington, D.C., U.S. Environmental Protection Agency, Office of Water, 841-B-99-002, p. $6 / 1-6 / 23$.

Strahler, A.N., 1957, Quantitative analysis of watershed geomorphology: American Geophysical Union Transactions v. 38, p. 913-920.

U.S. Census Bureau, 2011, State and county quickfacts: accessed June 2011, at http://quickfacts.census.gov/qfd/ states/20000.html.

U.S. Department of Agriculture, 2007, Kansas Annual Precipitation: accessed August 2011, at ftp://ftp-fc.sc.egov.usda. gov/KS/Outgoing/Web_Files/Technical_Resources/Maps/ ks_08_22.pdf. 
U.S. Environmental Protection Agency, 1998, The incidence and severity of sediment contamination in surface waters of the United States, volume 1-National sediment survey: U.S. Environmental Protection Agency Report, EPA-823R-97-006, various pagination.

U.S. Environmental Protection Agency, 2002, Summary of biological assessment programs and biocriteria development for states, tribes, territories, and interstate commissionsstreams and wadeable rivers: U.S. Environmental Protection Agency Report, EPA 822-R-02-048, various pagination.

U.S. Environmental Protection Agency, 2003, Ecoregion criteria: accessed November 2011, at http://water.epa.gov/ scitech/swguidance/standards/criteria/nutrients/ecoregions/ index.cfm

U.S. Environmental Protection Agency, 2005, Aquatic life ambient water quality criteria - nonylphenol: U.S. Environmental Protection Agency Report, EPA-822-R-05-005, information available on Web, accessed April 2009, at http://epa.gov/waterscience/criteria/nonylphenol/final-doc. $p d f$.

U.S. Environmental Protection Agency, 2008, Ecological toxicity information: accessed September 30, 2008, at http:// epa.gov/R5Super/ecology/toxprofiles.htm.

U.S. Environmental Protection Agency, 2012, National recommended water quality criteria: accessed January 2012, at http://water.epa.gov/scitech/swguidance/standards/current/.

U.S. Geological Survey, 2006, Collection of water samples (ver. 2.0): U.S. Geological Survey Techniques of WaterResources Investigations, book 9, chap. A4, accessed August 2012, at http://water.usgs.gov/owq/FieldManual/ chapter4/html/Ch4_contents.html

Van Dam, H., Mertens, A., and Sinkledam, J., 1994, A coded checklist and ecological indicator values of freshwater diatoms from the Netherlands: Netherlands Journal of Aquatic Ecology, v. 28, no. 1, p. 117-133.

Waite, I.R., Brown, L.R., Kennen, J.G., May, J.T., Cuffney, T.F., Orlando, J.L., and Jones, K.A., 2010, Comparison of watershed disturbance predictive models for stream benthic macroinvertebrates for three distinct ecoregions in western US: Ecological Indicators, v. 10, p. 1125-1136.
Walsh, C.J., Fletcher, T.D., and Ladson, A.R., 2005, Stream restoration in urban catchments through redesigning storm water systems - looking to the catchment to save the stream: Journal of the North American Benthological Society, v. 24, p. 690-705.

Walters, D.M., Leigh, D.S., and Bearden, A.B., 2003, Urbanization, sedimentation, and the homogenization of fish assemblages in the Etowah River Basin, USA: Hydrobiologia, v. 494 , p. 5-10.

Washington, H.G., 1984, Diversity, biotic and similarity indices - a review with special reference to aquatic systems: Water Resources, v. 18, no. 6, p. 653-694.

Waters, T.F., 1995, Sediment in streams - sources, biological effects, and control: American Fisheries Society Monograph 7.

Welch, E.B., Jacoby, J.M., Horner, R.R., and Seeley, M.R., 1988, Nuisance biomass levels of periphytic algae in streams: Hydrobiologia, v. 157, p. 161-168.

Wilkison, D.H., D.J. Armstrong, and D.W. Blevins, 2002, Effects of wastewater and combined sewer overflows on water quality in the Blue River basin, Kansas City, Missouri and Kansas, July 1998-October 2000: U.S. Geological Survey Water-Resources Investigations Report 02-4107, 162 p.

Wilkison, D.H., Armstrong, D.J., Norman, R.D, Poulton, B.C., Furlong, E.T., and Zaugg, S.D., 2006, Water-quality in the Blue River Basin, Kansas City metropolitan area, Missouri and Kansas, July 1998 to October 2004: U.S. Geological Survey Scientific Investigations Report 2006-5147, 170 p.

Wilkison, D.H., Armstrong, D.J., and Hampton, S.A., 2009, Character and trends of water quality in the Blue River Basin, Kansas City metropolitan area, Missouri and Kansas, 1998 through 2007: U.S. Geological Survey Scientific Investigations Report 2009-5169, 211 p.

Zelt, R.B., and Munn, M.D., 2009, Riparian and associated habitat characteristics related to nutrient concentrations and biological responses of small streams in selected agricultural areas, United States, 2003-04: U.S. Geological Survey Scientific Investigations Report 2009-5224, 78 p. 



\section{Appendixes}


Appendix 1. Organic compounds analyzed in streambed sediment samples from biological monitoring sites in Johnson County, Kansas, 2003, 2007, and 2010. (All compounds are reported in micrograms per liter.)

[ $\mu \mathrm{g} / \mathrm{L}$, micrograms per liter; CAS, Chemical Abstracts Service; PAH, polycyclic aromatic hydrocarbon; --, not available]

\begin{tabular}{|c|c|c|c|}
\hline Compound name & $\begin{array}{l}\text { General uses or sources (from Burkhardt and others, } \\
\text { 2006; Hladik and others, 2009) }\end{array}$ & $\begin{array}{c}\text { CAS }^{1} \\
\text { number }\end{array}$ & $\begin{array}{c}\text { Laboratory } \\
\text { reporting } \\
\text { level ( } \mu \mathrm{g} / \mathrm{L})\end{array}$ \\
\hline 1,4-Dichlorobenzene & Moth repellent, fumigant, deodorant & $106-46-7$ & 50 \\
\hline 1-Methylnaphthalene & Gasoline, diesel fuel, crude oil & $90-12-0$ & 50 \\
\hline 2,2',4,4'-Tetrabromodiphenylether & Fire retardant & $5436-43-1$ & 50 \\
\hline 2,6-Dimethylnaphthalene & Diesel, kerosene & $581-42-0$ & 50 \\
\hline 3-beta-Coprostanol & Carnivore fecal indicator & $360-68-9$ & 500 \\
\hline 3-Methyl-1(H)-indole (Skatole) & Fragrance, odor in feces and coal tar & $83-34-1$ & 50 \\
\hline 3-tert-Butyl-4-hydroxy anisole (BHA) & Antioxidant, general preservative & $121-00-6$ & 150 \\
\hline 4-Cumylphenol & Nonionic detergent metabolite & $599-64-4$ & 50 \\
\hline 4-tert-Octylphenol & Nonionic detergent metabolite & $140-66-9$ & 50 \\
\hline 4-tert-Octylphenol diethoxylate (OP2EO) & Nonionic detergent metabolite & $2315-61-9$ & 50 \\
\hline 4-tert-Octylphenol monoethoxylate (OP1EO) & Nonionic detergent metabolite & $2315-67-5$ & 250 \\
\hline Acetophenone & Fragrance in detergent and tobacco, flavor in beverages & $98-86-2$ & 150 \\
\hline Acetyl hexamethyl tetrahydronaphthalene (AHTN) & Common musk fragrance & $21145-77-7$ & 50 \\
\hline Anthracene & $\begin{array}{l}\text { PAH, wood preservative, tar, diesel, crude oil, combus- } \\
\text { tion product }\end{array}$ & $120-12-7$ & 50 \\
\hline Anthraquinone & Manufacture dye, seed treatment, bird repellent & $84-65-1$ & 50 \\
\hline Atrazine & Herbicide & $1912-24-9$ & 100 \\
\hline Bromacil & General use herbicide & $314-40-9$ & 500 \\
\hline Camphor & Flavor, odorant, ointments & $76-22-2$ & 50 \\
\hline Carbazole & Insecticide, dyes, explosives, lubricants & $86-74-8$ & 50 \\
\hline Chlorpyrifos & Insecticide, pest and termite control & $2921-88-2$ & 50 \\
\hline Cholesterol & Fecal indicator & $57-88-5$ & 250 \\
\hline d-Limonene & Fungicide, antimicrobial, antiviral, fragrance & $5989-27-5$ & 50 \\
\hline Diazinon & Insecticide & $333-41-5$ & 50 \\
\hline Diethyl phthalate & Plasticizer & $84-66-2$ & 100 \\
\hline Fluoranthene & PAH, combustion product, coal tar & $206-44-0$ & 50 \\
\hline $\begin{array}{l}\text { Hexahydrohexamethylcyclopentabenzopyran } \\
\text { (HHCB) }\end{array}$ & Musk fragrance & $1222-05-5$ & 50 \\
\hline Indole & Inert pesticide ingredient, coffee fragrance & $120-72-9$ & 100 \\
\hline Isoborneol & Perfume and disinfectant fragrance & $124-76-5$ & 50 \\
\hline Isophorone & Solvent for lacquer, plastic, oil, silicon, resins & $78-59-1$ & 50 \\
\hline Isopropylbenzene & Manufacture phenol/acetone, fuels, paint thinner & $98-82-8$ & 100 \\
\hline
\end{tabular}


Appendix 1. Organic compounds analyzed in streambed sediment samples from biological monitoring sites in Johnson County, Kansas, 2003, 2007, and 2010. (All compounds are reported in micrograms per liter.)—Continued

[ $\mu \mathrm{g} / \mathrm{L}$, micrograms per liter; CAS, Chemical Abstracts Service; PAH, polycyclic aromatic hydrocarbon; --, not available]

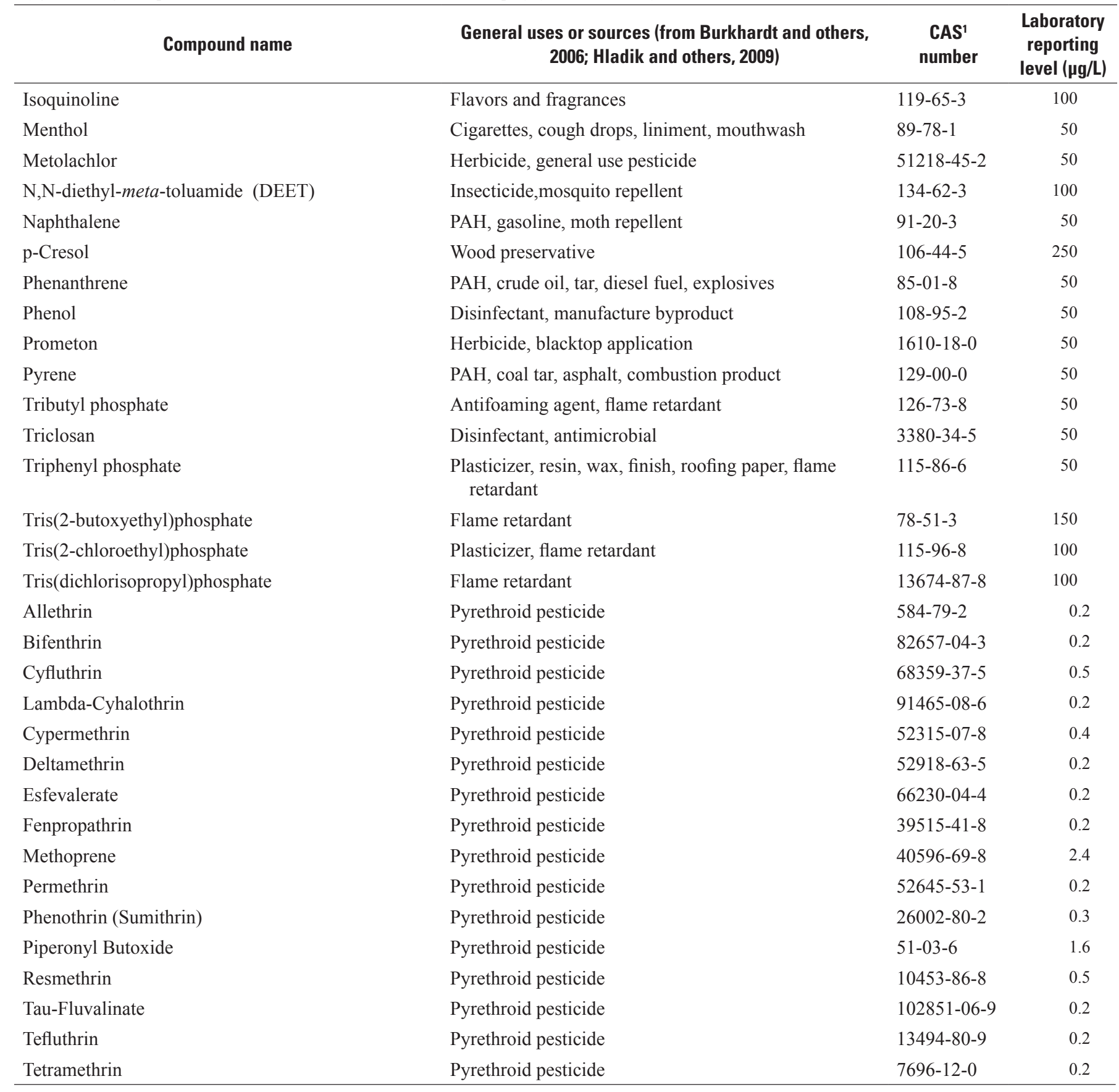

${ }^{1}$ This report contains CAS Registry Numbers ${ }^{\mathrm{TM}}$, which is a Registered Trademark of the American Chemical Society. CAS recommends the verification of the CASRNs through CAS Client Services ${ }^{\mathrm{SM}}$. 
Appendix 2. Summary of variables used to assess stream habitat conditions at biological monitoring sites in Johnson County, Kansas.

[ft/mi, feet per mile; $\mathrm{m} / \mathrm{km}$, meters per kilometer; $\mathrm{m}$, meter; $\mathrm{mm}$, millimeter. Each variable was ranked on a scale of 1 (poorest) to 12 (most optimal) on the basis of direct measurements, visual estimation, or examination of specific physical features. The complete field form is available in Rasmussen and others, 2009.]

\begin{tabular}{|c|c|}
\hline $\begin{array}{c}\text { Variable } \\
\text { (and spatial scale) }\end{array}$ & Description \\
\hline \multicolumn{2}{|r|}{ Category 1. Channel conditions and characteristics } \\
\hline $\begin{array}{l}\text { B. Channel slope and } \\
\text { morphological status } \\
\text { (reach) }\end{array}$ & $\begin{array}{l}\text { Indicates the degree of incision, downcutting, or headcutting that has occurred in the channel. Considered op- } \\
\text { timal when bank elevations are near the elevation of the active flood plain, the channel cross-section is V- or } \\
\text { U-shaped, there is little evidence of lateral or downcutting, the mean bank slope is less than } 15 \text { percent, and } \\
\text { the mean difference between right and left bank slopes is greater than } 5 \text { percent. Poor conditions exist when } \\
\text { banks are much higher than the elevation of the active flood plain, the channel is trapezoid-shaped, mean } \\
\text { bank slope is greater than } 35 \text { percent, and the mean difference between right and left bank slopes is less than } \\
2 \text { percent. }\end{array}$ \\
\hline C. Sinuosity (segment) & $\begin{array}{l}\text { Describes the meandering of the stream. Conditions for sinousity are optimal when the bends in the stream in- } \\
\text { crease the stream length three to four times compared to a straight line and poorest if the channel is straight } \\
\text { as a result of channelization. }\end{array}$ \\
\hline $\begin{array}{l}\text { E. Riffle frequency (seg- } \\
\text { ment) }\end{array}$ & $\begin{array}{l}\text { Indicates the number of riffles in a segment. Conditions are optimal when elevation declines at least } 26 \mathrm{ft} / \mathrm{mi} \\
(5 \mathrm{~m} / \mathrm{km}) \text { and at least four riffles occur within the segment, and poor if the elevation decreases at less than } \\
\text { about } 5 \mathrm{ft} / \mathrm{mi}(1 \mathrm{~m} / \mathrm{km}) \text { and only one shallow riffle occurs. }\end{array}$ \\
\hline
\end{tabular}

\section{Category 2. Bank and riparian conditions}

A. Bank stability (reach)

A measure of the left and right bank erosion and potential erosion during periods of increased streamflow. Considered optimal when banks appear stable throughout the reach, less than 5 percent of the banks show evidence of erosion, and more than one-third of the erodible banks on the outside bends are protected by roots or vegetation. Conditions are poor when 60 to 100 percent of the banks have erosional scars.

B. Canopy cover (reach) Indicates the percentage of the reach that is shaded by overhanging vegetation and other features in the stream channel. Canopy cover is considered optimal when 50-80 percent is shaded and poorest when less than 10 percent or greater than 90 percent is shaded.

C. Bank/ riparian protection (reach)

Indicates how well the streambank and near-stream portion of the riparian zone resist erosion, take up nutrients, and control in-stream scouring. Bank/riparian protection is optimal when more than 90 percent of the streambank surfaces and nearby riparian zones are covered by vegetation and poorest when less than 50 percent of the streambank surfaces are covered by native vegetation.

D. Length and extent of buffers (segment/reach)

Provides an estimate of both the extent of buffers (land covered with natural vegetation such as forests, shrubs, or grasses) and the number of gaps in the longitudinal continuity. Conditions are considered optimal when the mean longitudinal length of buffers that are at least $20 \mathrm{ft}(6 \mathrm{~m})$ wide within the segment extends along at least 90 percent of both banks. Conditions are poor when the mean longitudinal length of buffers encompasses less than 70 percent along both banks.

E. Average natural buffer width (reach)

A wider natural buffer allows runoff more time to percolate into soils or be filtered by vegetation before entering the stream. Wider, more vegetated, and less-disturbed riparian zones also produce more organic matter that provides a constant supply of energy to the stream. Conditions are considered optimal when the mean buffer width is larger than $60 \mathrm{ft}$ on both banks and poorest when the mean buffer width is less than $20 \mathrm{ft}$.

F. Percent altered banks (reach)

Indicates large-scale changes in the shape of the stream channel. Conditions are optimal when no alteration activities are occuring in the reach and past human activities affect less than 10 percent of the total bank and buffer area. Conditions are poor when multiple activities or features are present or more than 70 percent of the bank and buffer area are affected by human activities. 
Appendix 2. Summary of variables used to assess stream habitat conditions at biological monitoring sites in Johnson County, Kansas.-Continued

[ft/mi, feet per mile; $\mathrm{m} / \mathrm{km}$, meters per kilometer; $\mathrm{m}$, meter; $\mathrm{mm}$, millimeter. Each variable was ranked on a scale of 1 (poorest) to 12 (most optimal) on the basis of direct measurements, visual estimation, or examination of specific physical features. The complete field form is available in Rasmussen and others, 2009.]

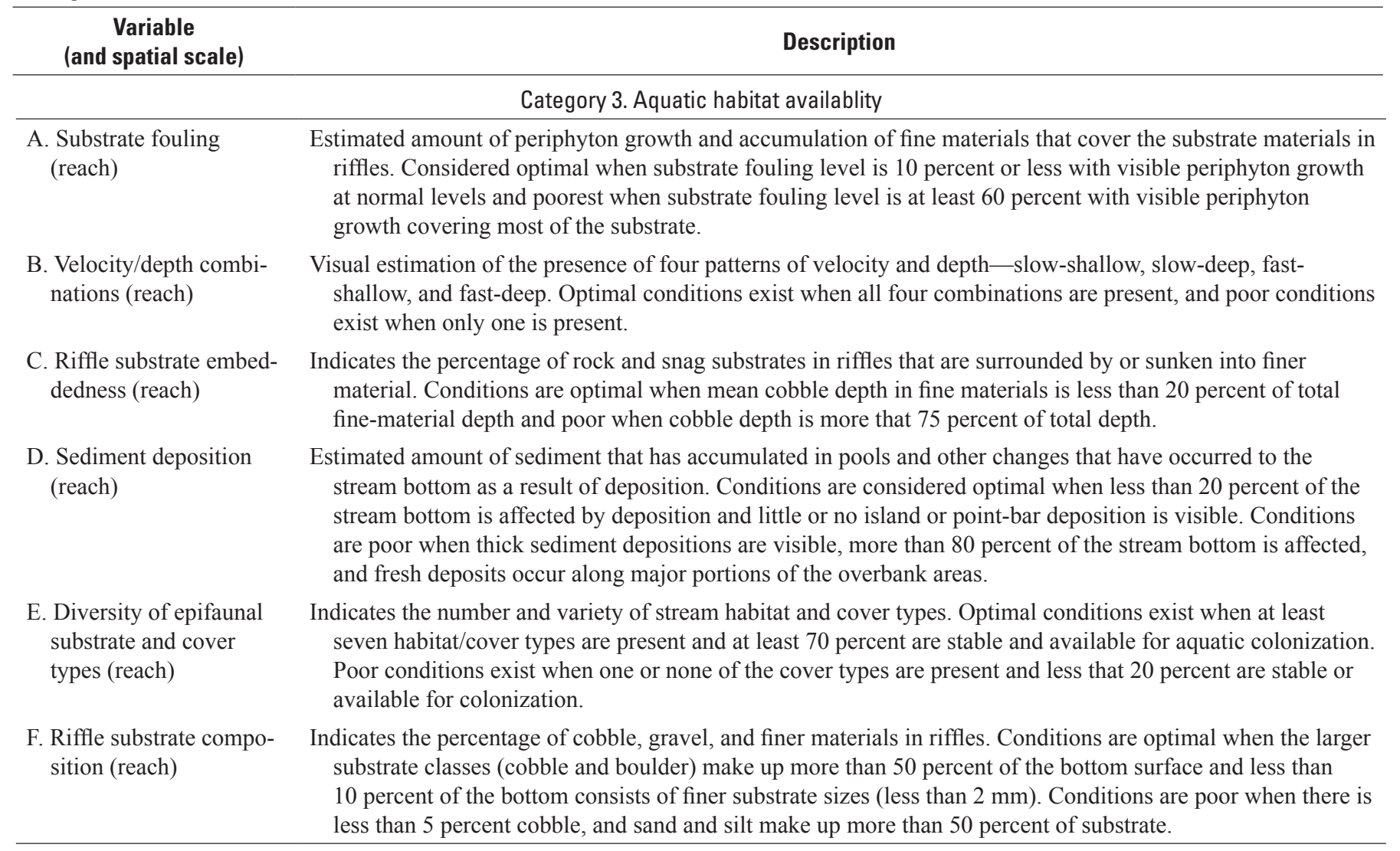




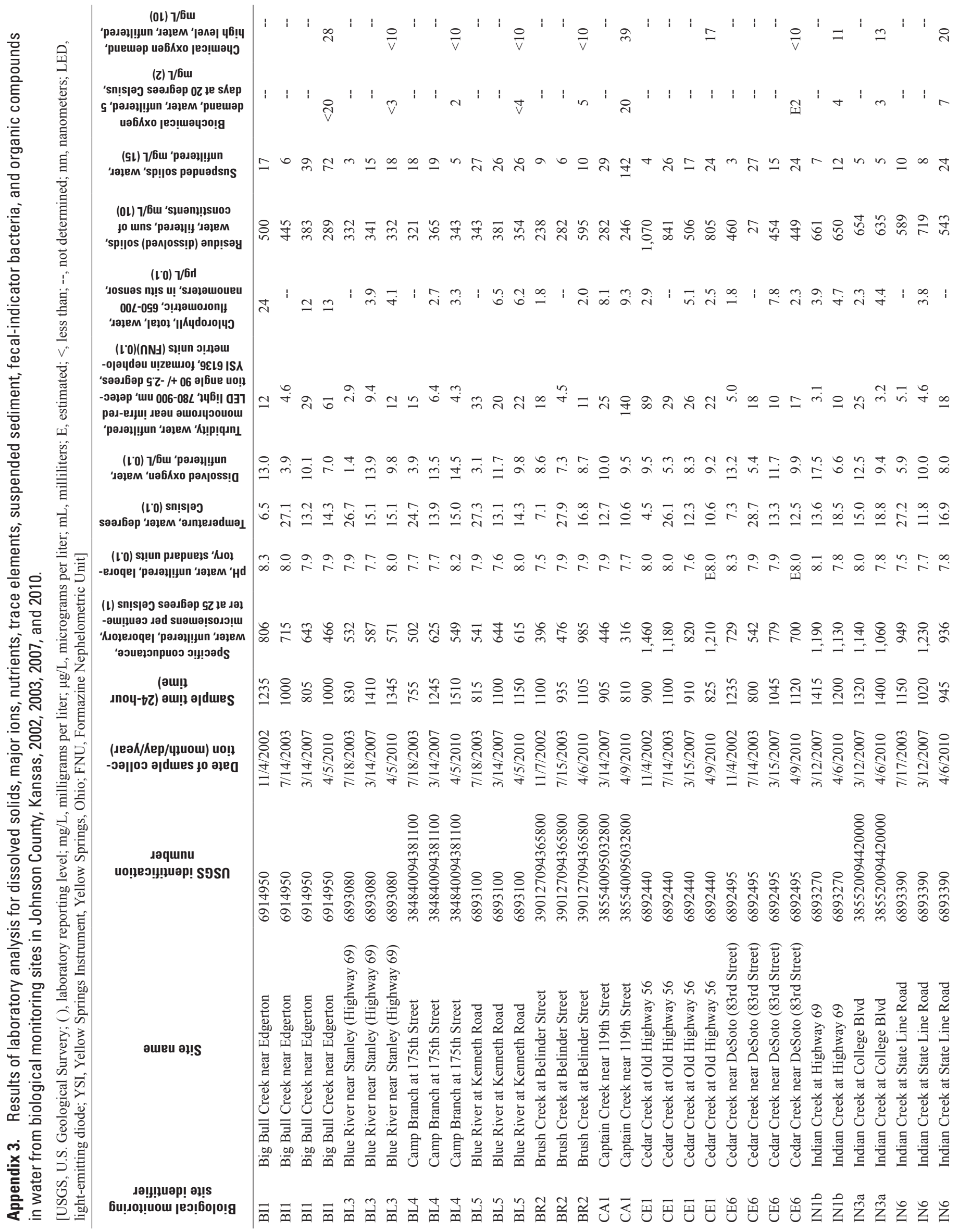




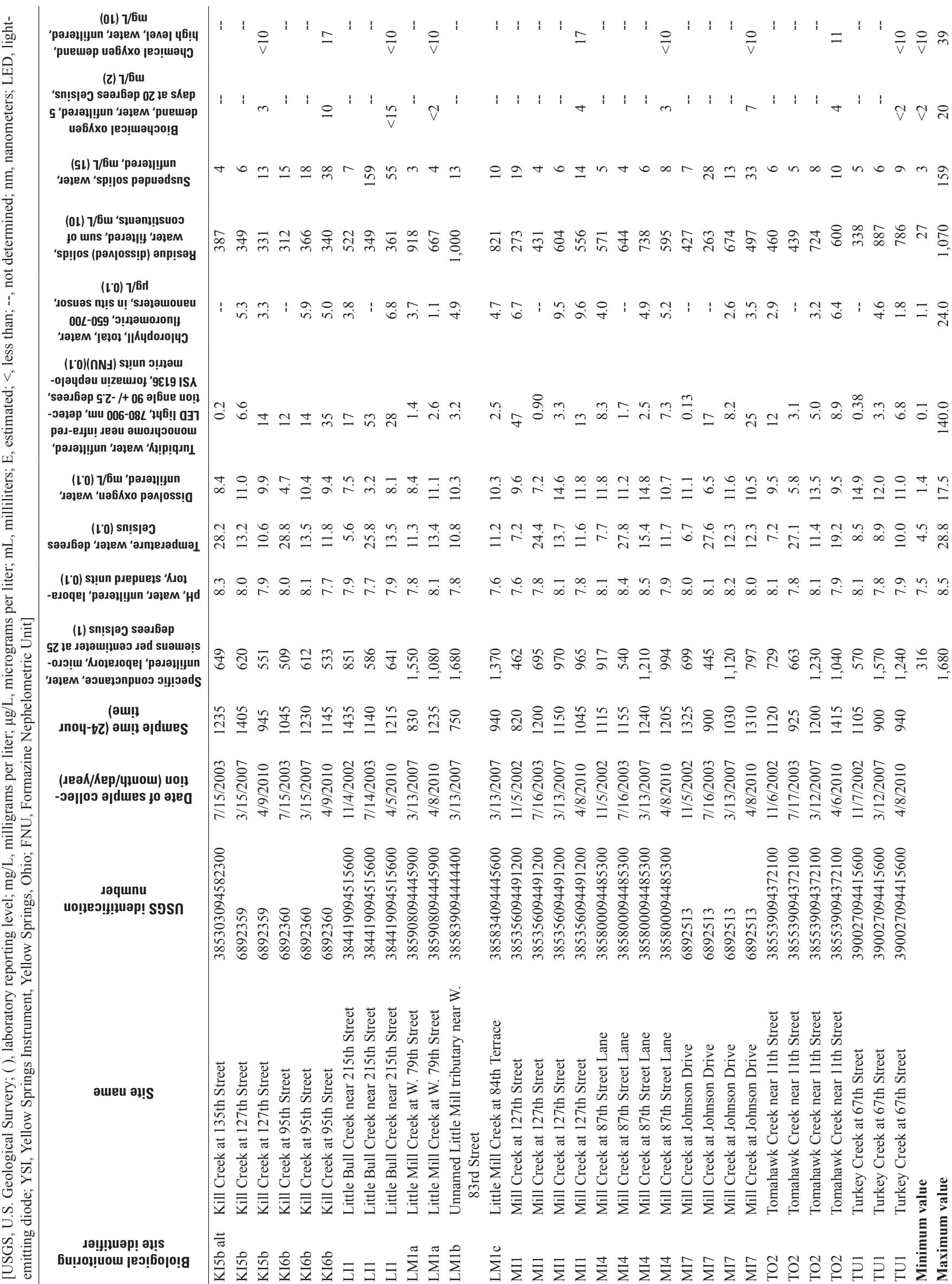




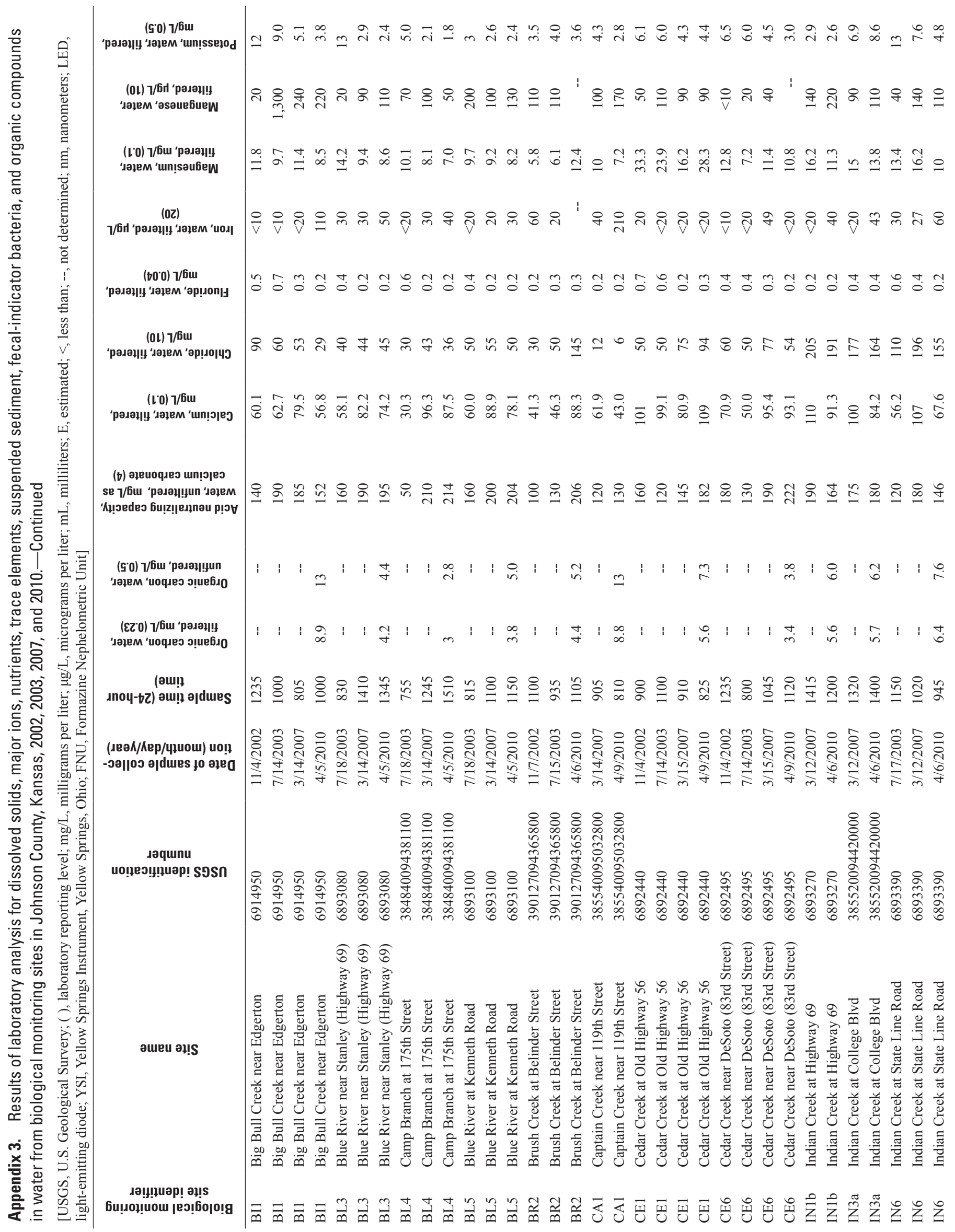




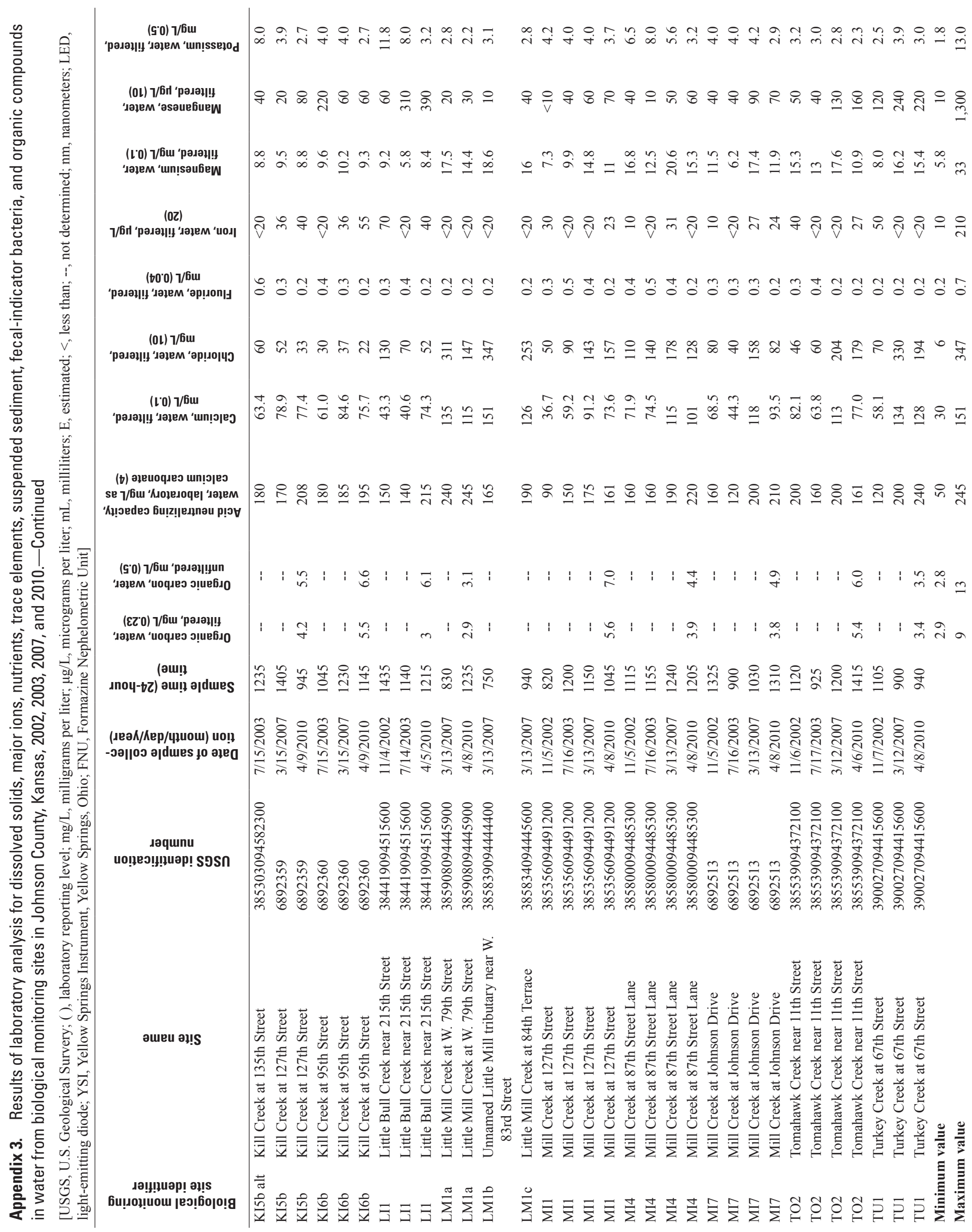




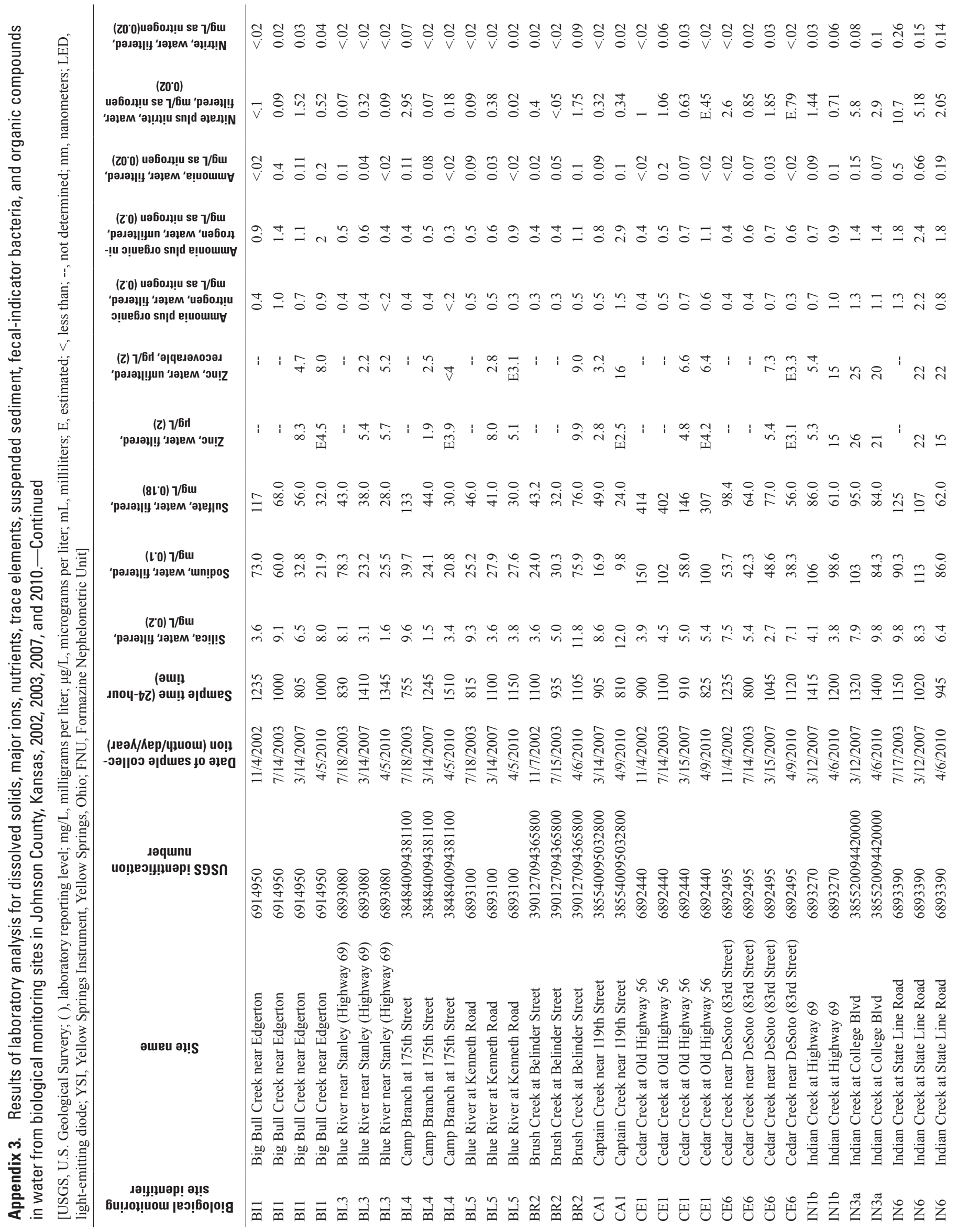




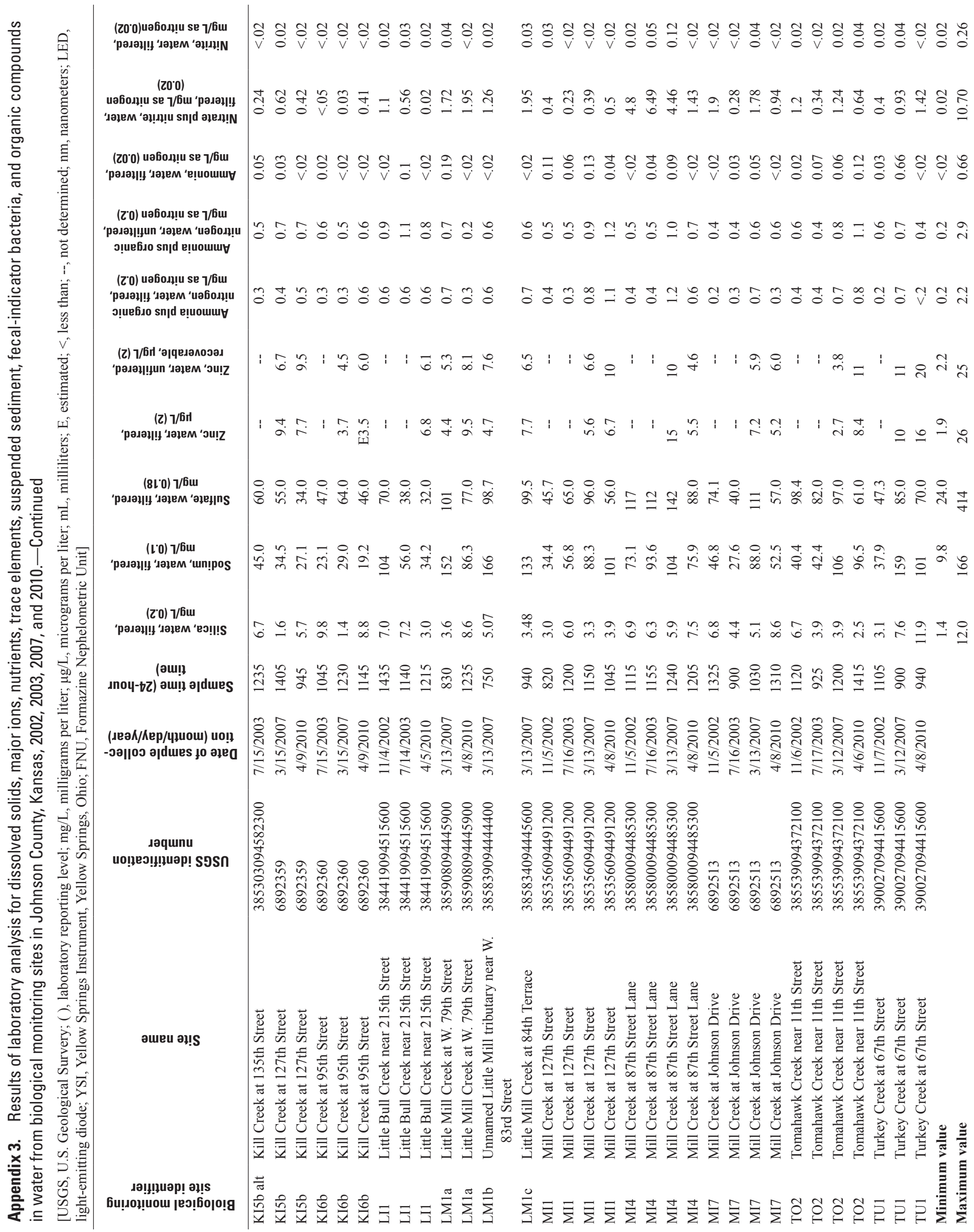




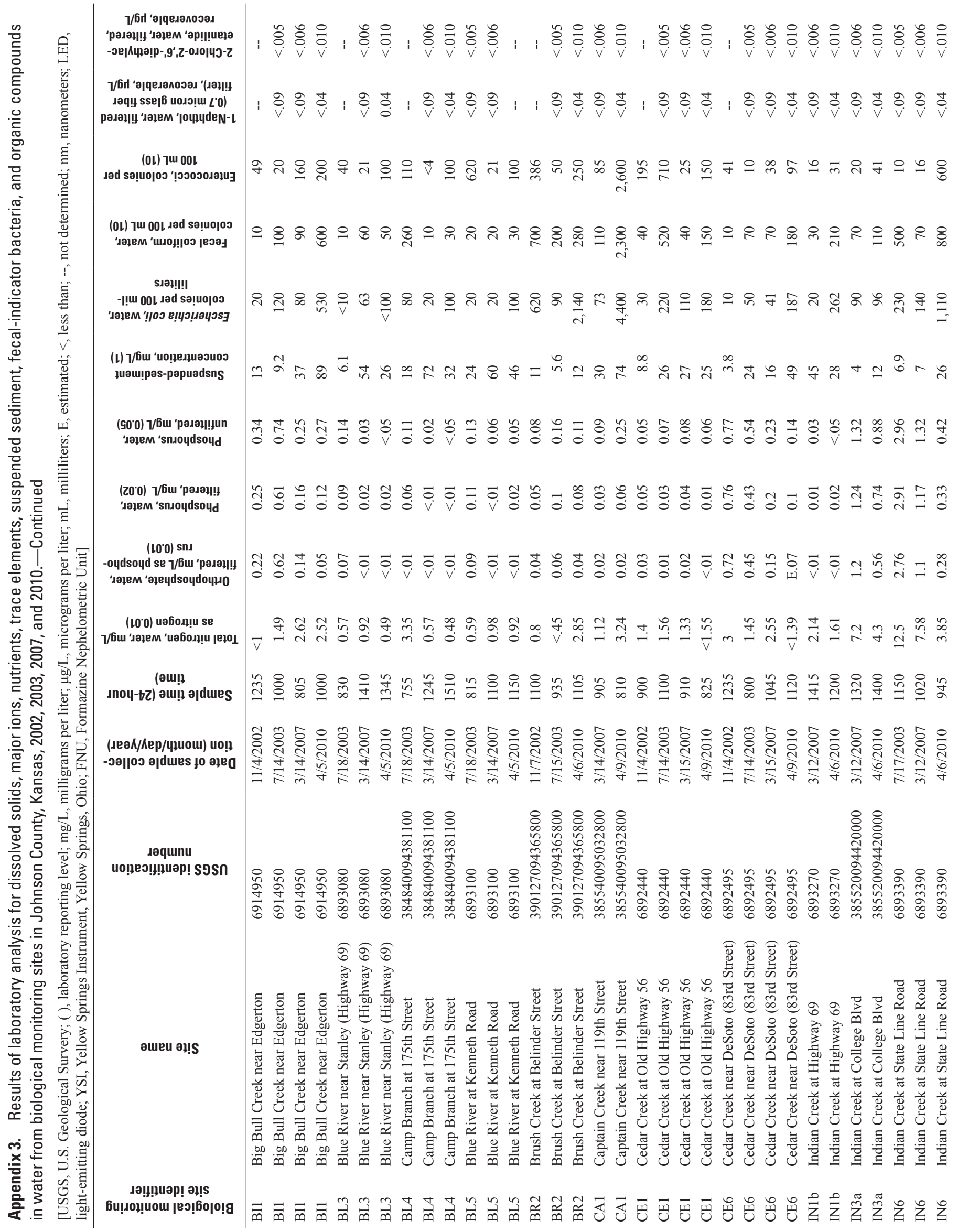




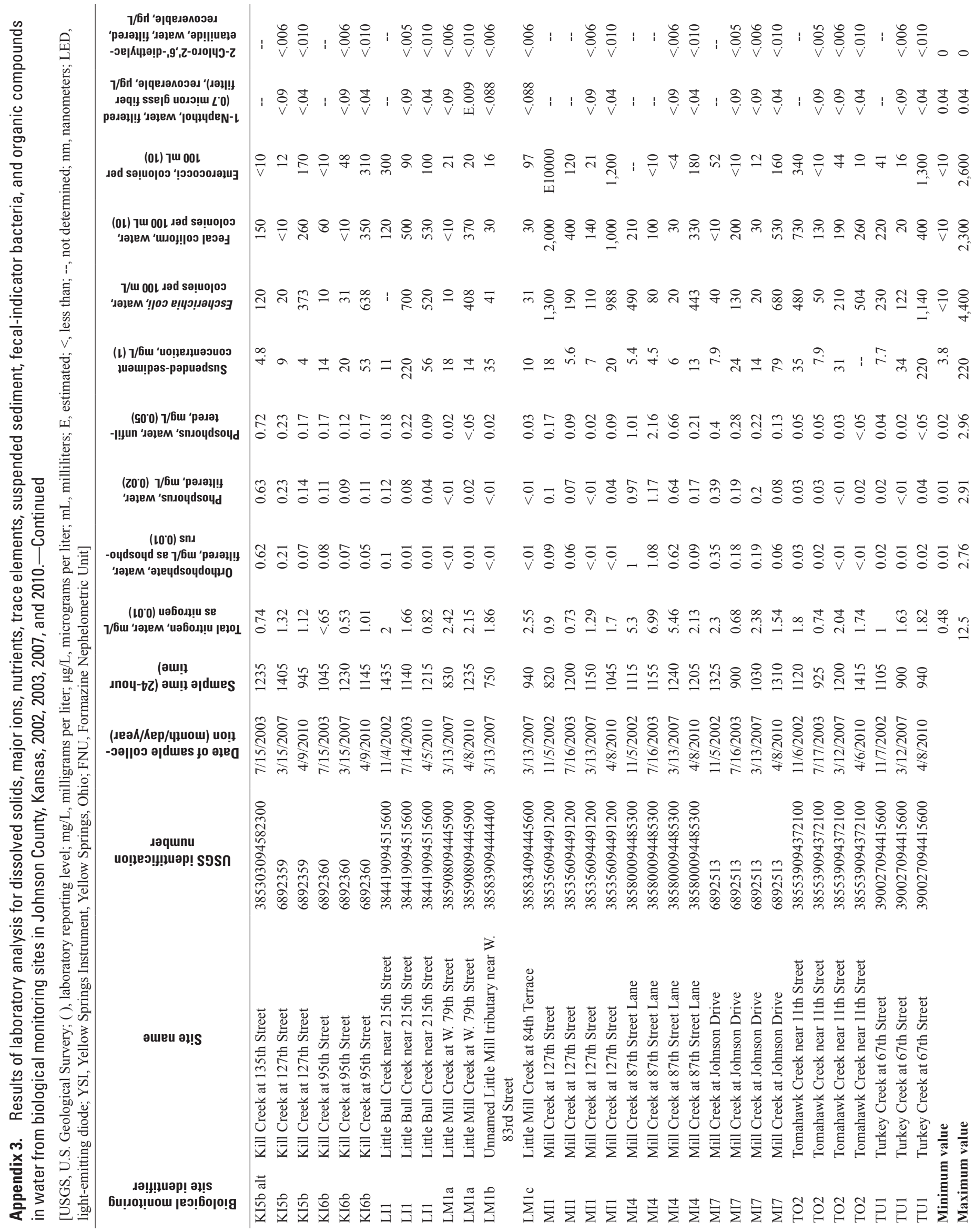




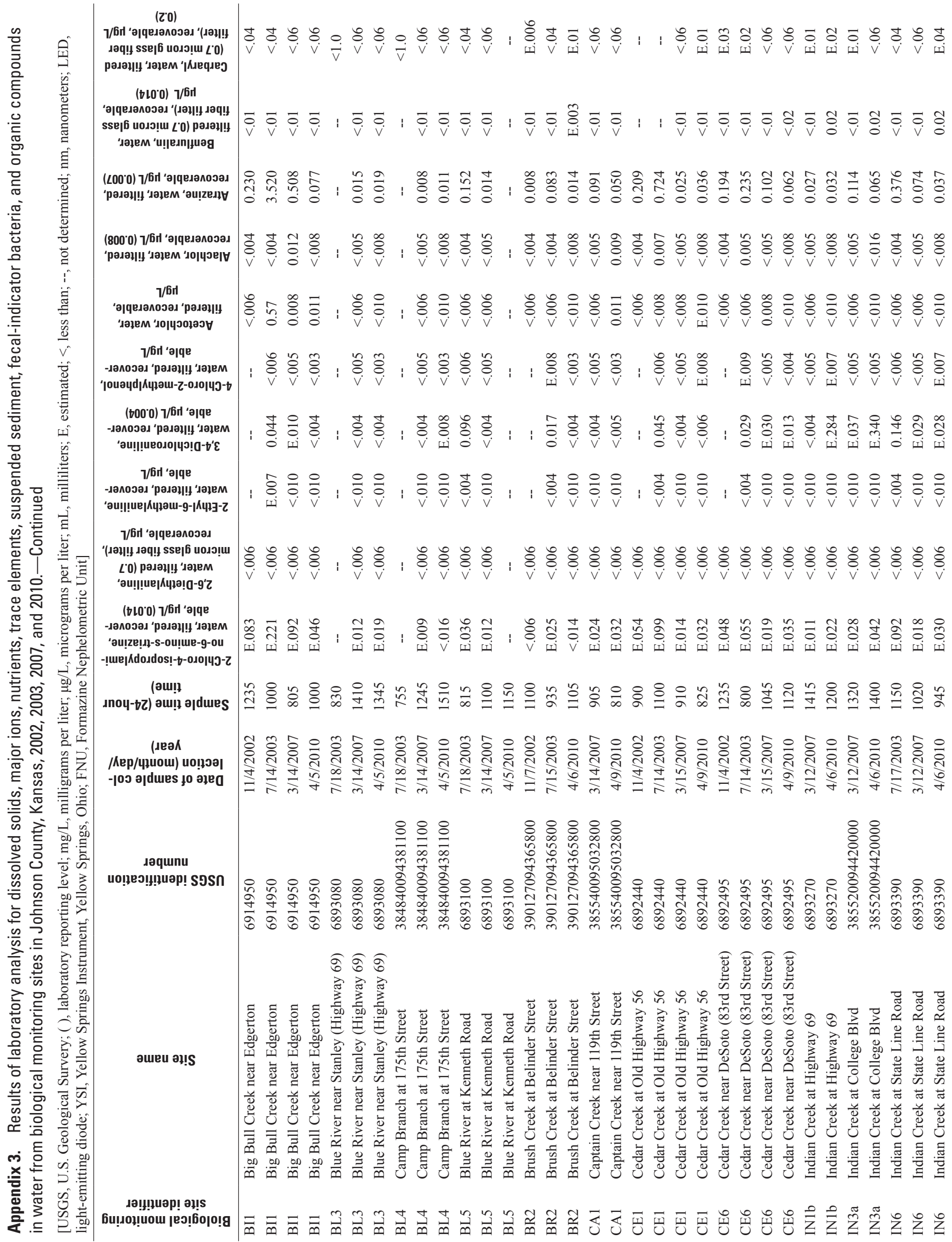




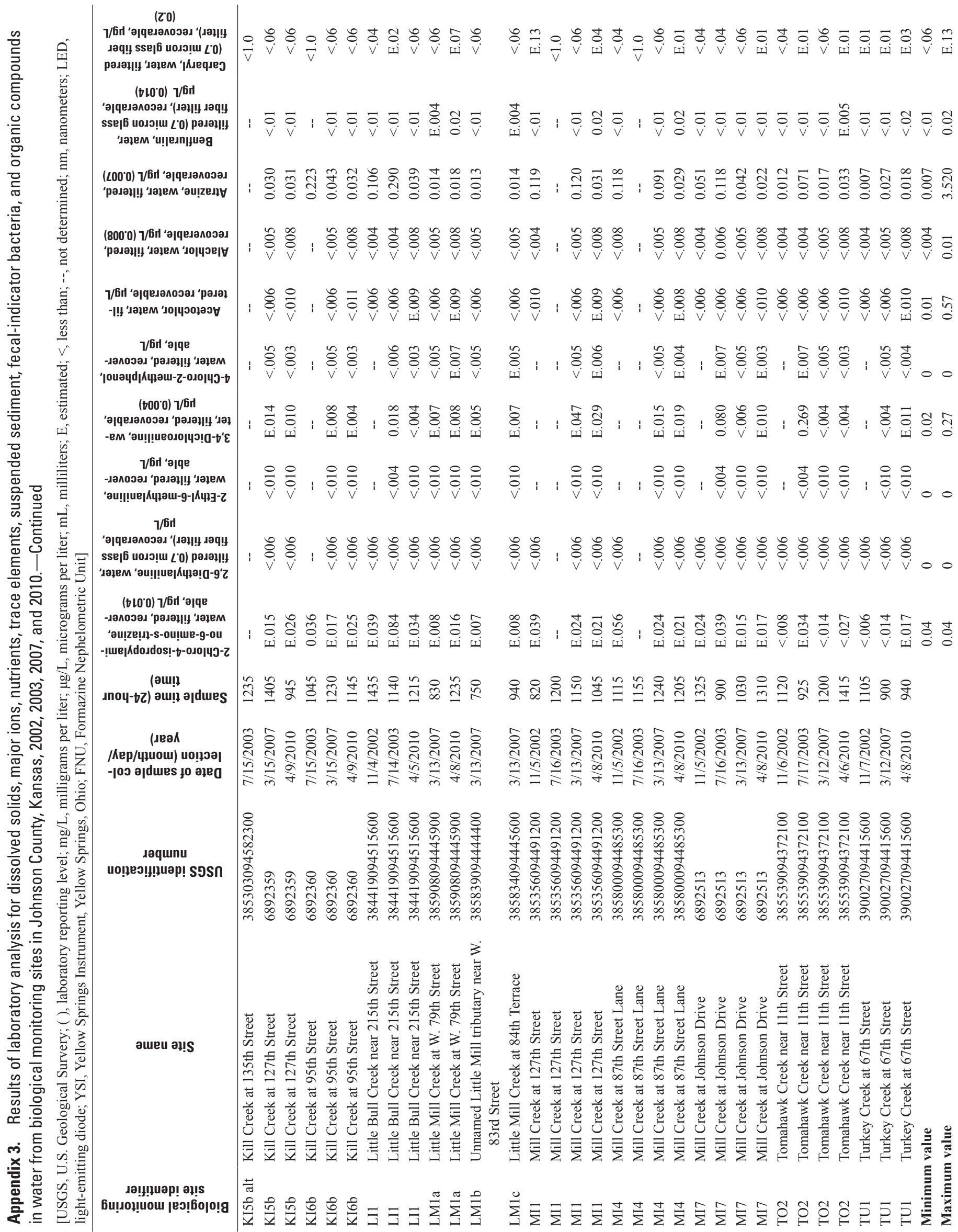




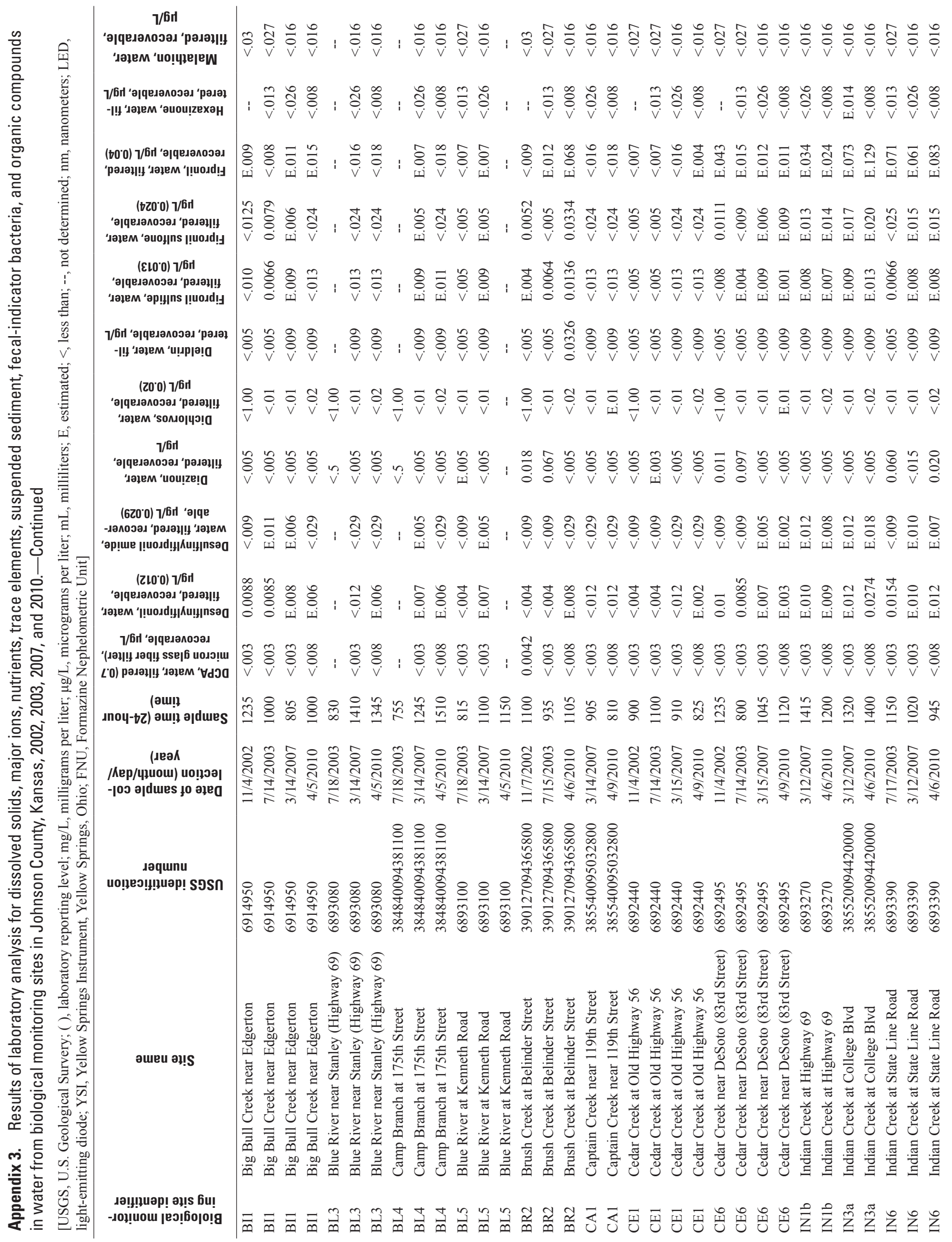




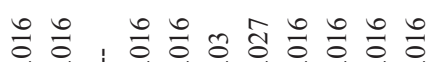
$\vee \vee v \vee v \vee v \vee v v$ i

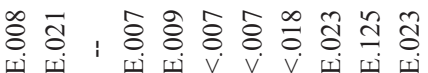

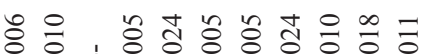
เi

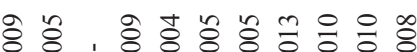

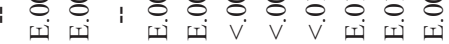

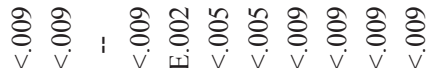

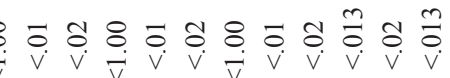
ڤิ

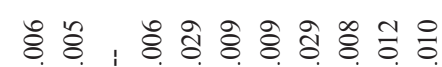

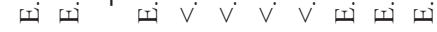
\&̊ \&, मن \%ิ̊

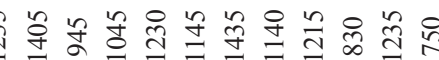

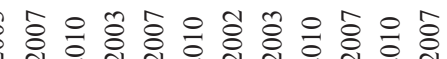

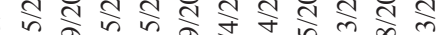

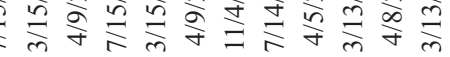

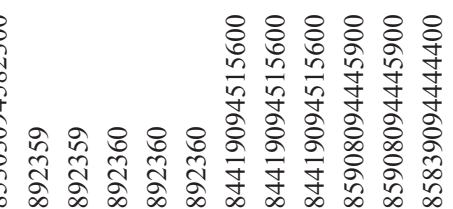

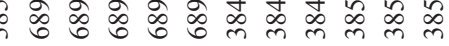

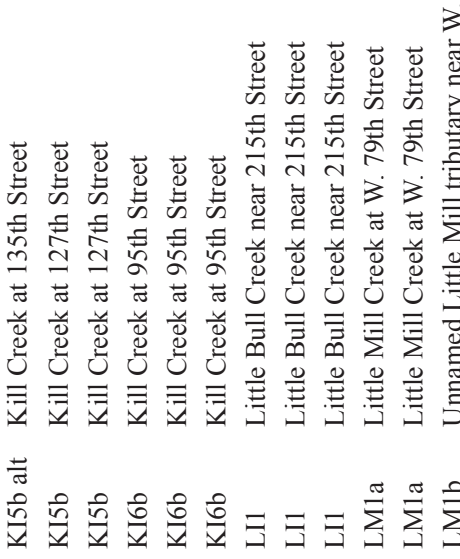

tே

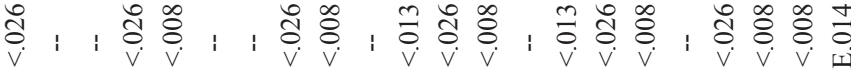

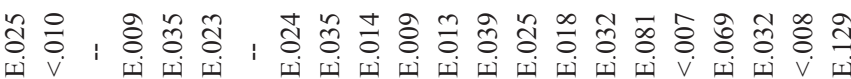

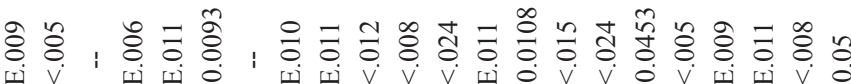
oे $\tilde{\delta}, \quad \delta$ oे

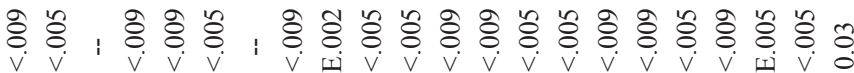

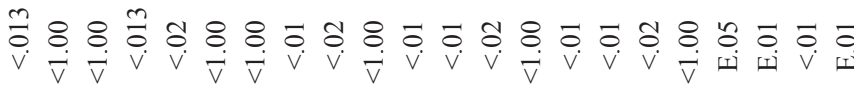

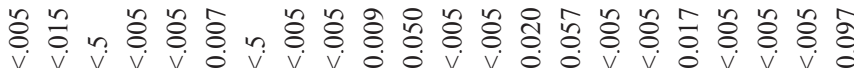

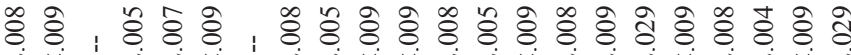

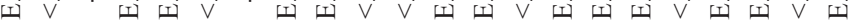
\&े ఫ, \& ڤิ

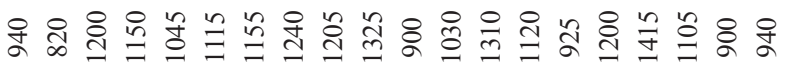
领

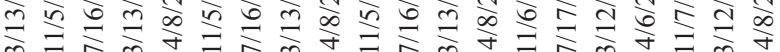

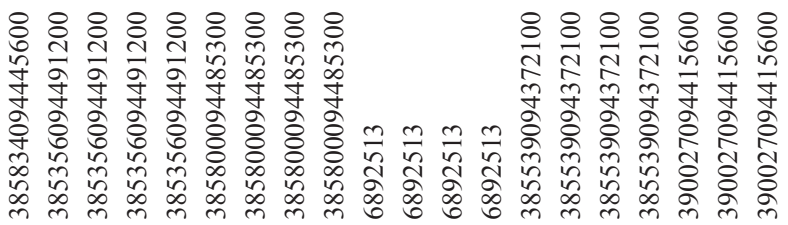

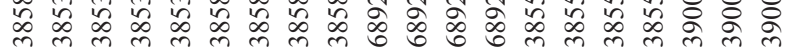

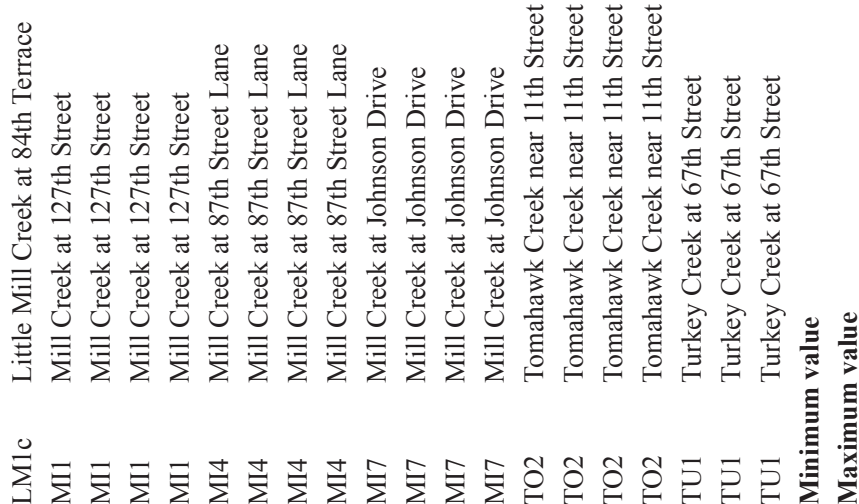




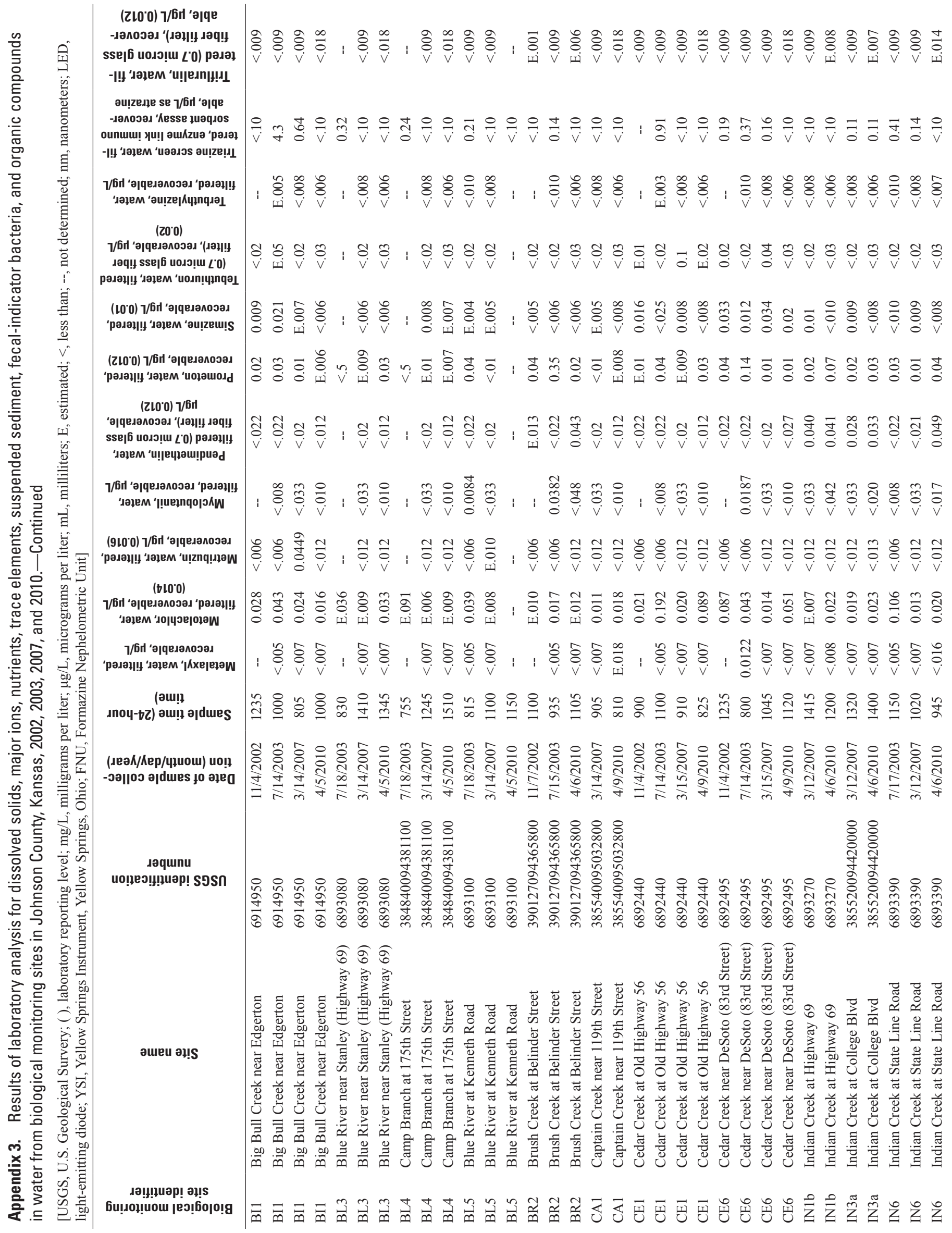




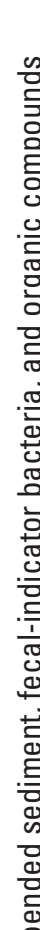

(Z10'0)

尊

a

芯

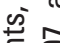

잃 을

至

드 으

흐음

ब苋

is

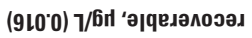

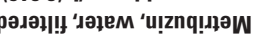

(blo'0)

$7 / 64$ 'әрчедәлоэәд ‘рәдәџ!!

‘әрем ‘орчэе|оюә

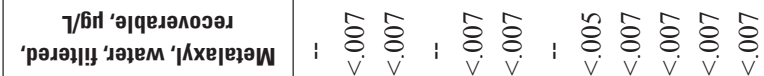

(aw!!

נnou-t乙) әu!! ə|dues

(деәК/Кер/чинош) uо!

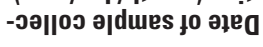

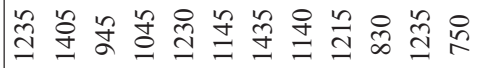

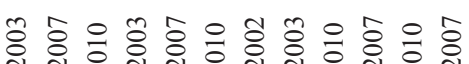

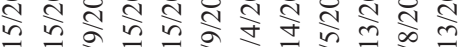

\section{要}$$
\text { (n) }
$$
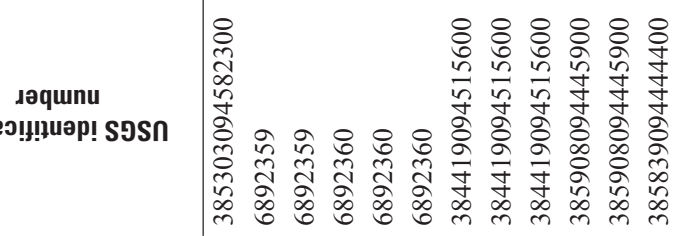

\section{量}

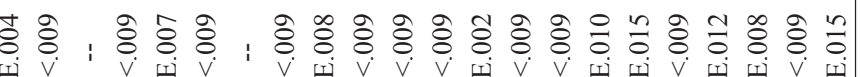

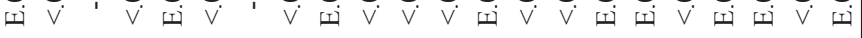

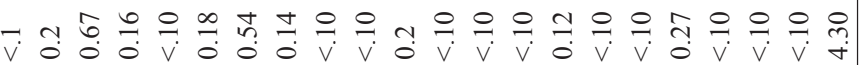

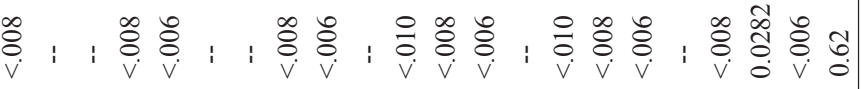
苛: \&

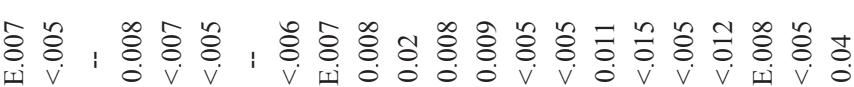

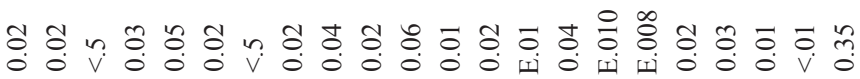

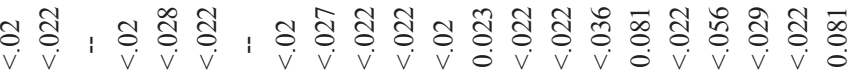

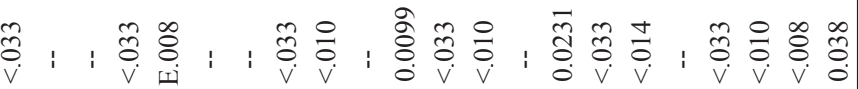

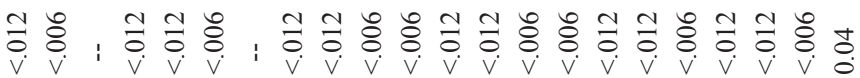

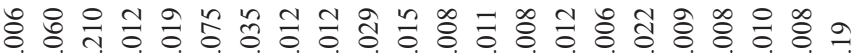
पi

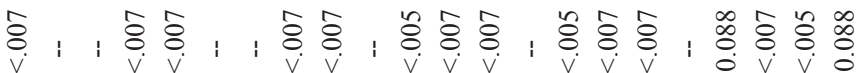

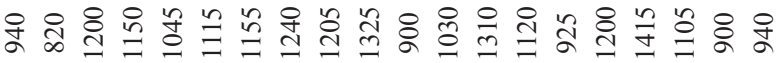

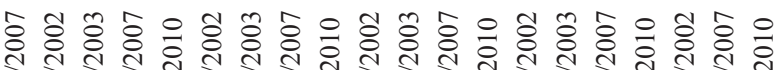

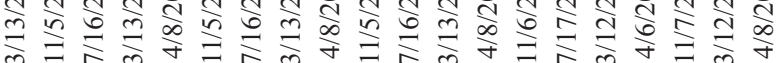

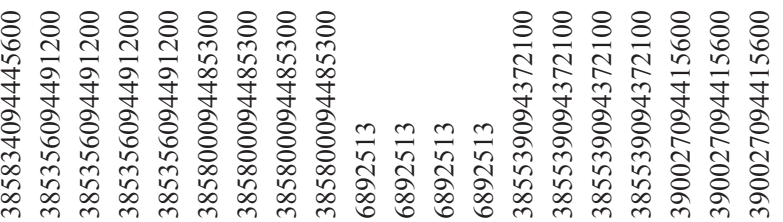

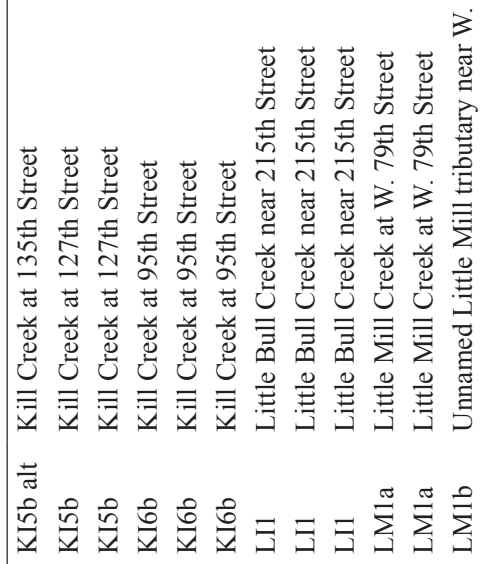

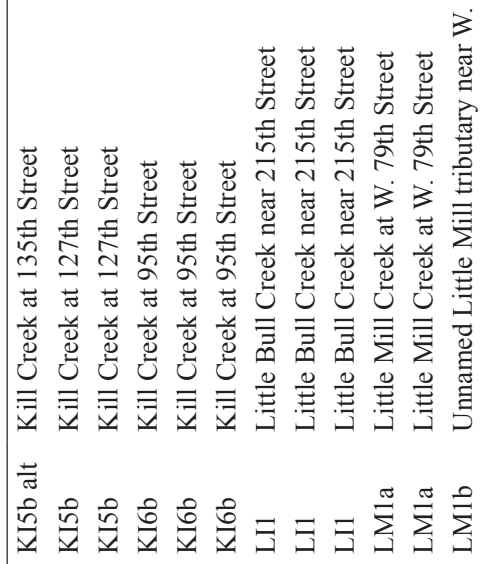

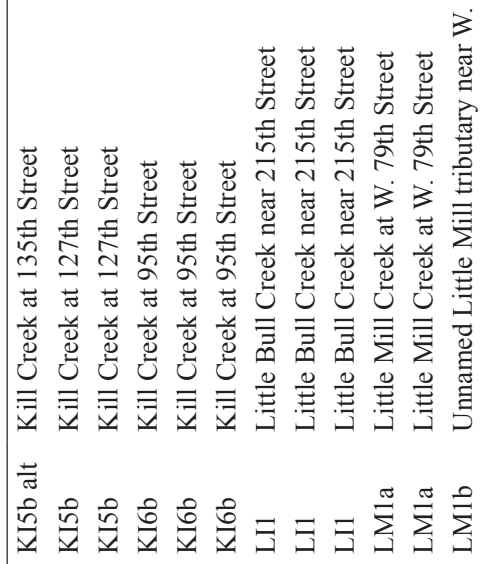

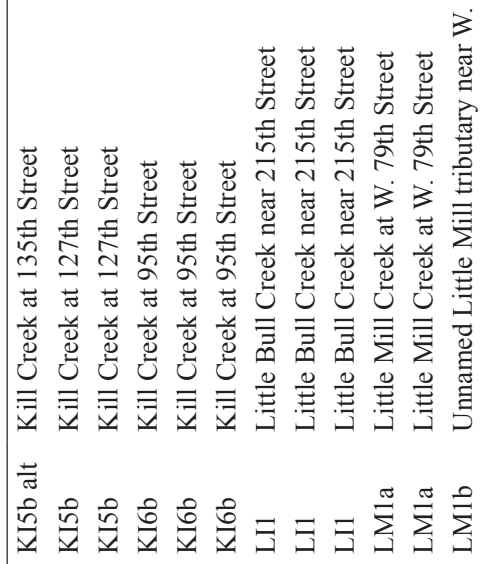
әแеน әฺ!

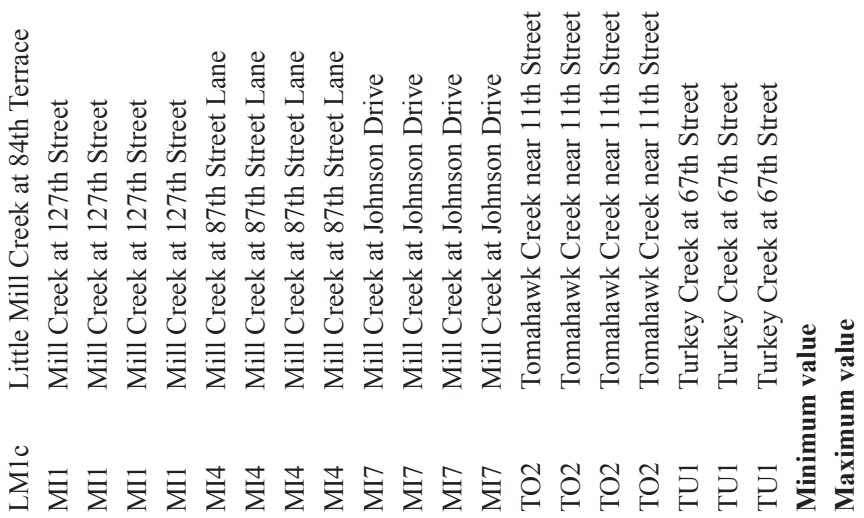




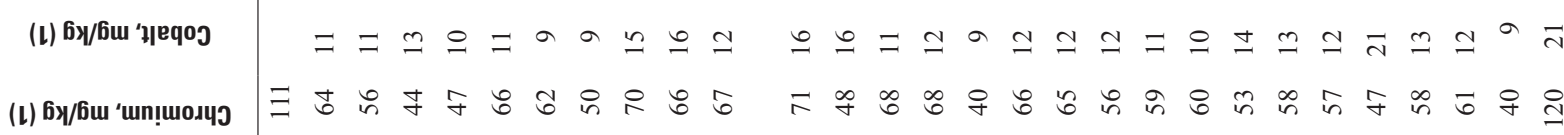
' \& \& \& \& \& \& '

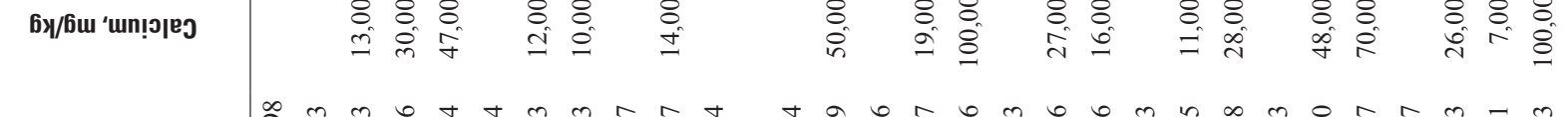

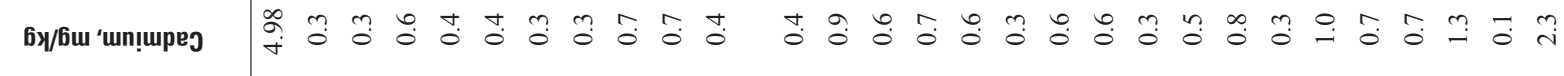

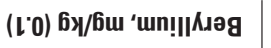
(L) 6y/6u 'un!eg

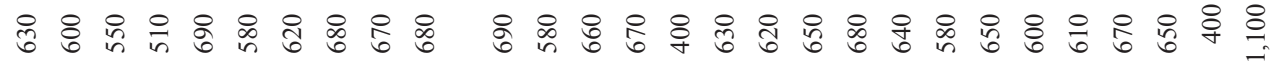

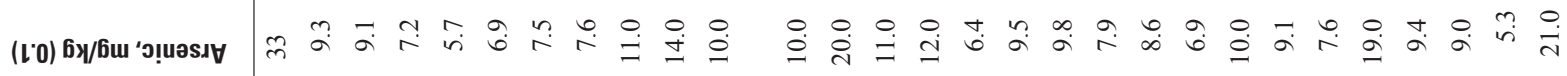

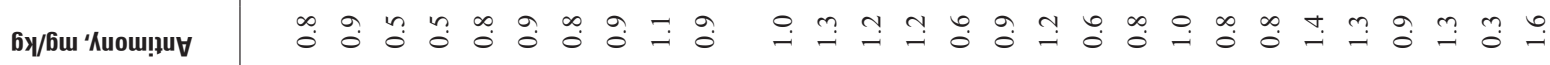
(เ) бy/6u 'unu!un| (001)

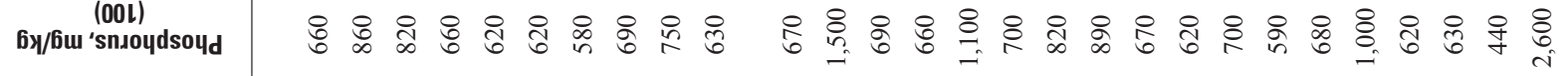
(00l) $6 y$

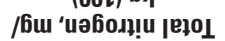
鹤

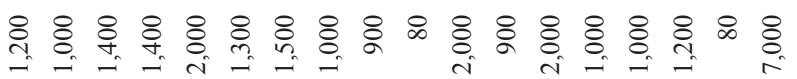
$\left(000^{\prime}\right)$ ) 6y /6u ‘uoqdes ग!̣efıо \& \& \& \& \& \& \&

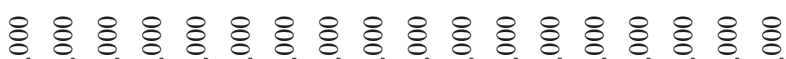

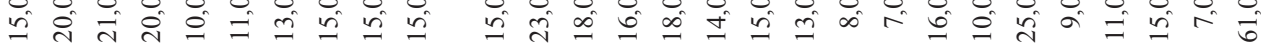

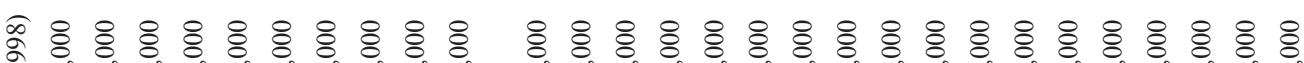
ग!uebıou!) иоqueว 空 (am!!

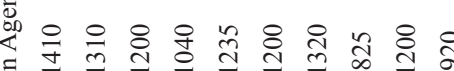

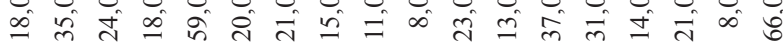

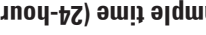

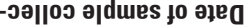
范

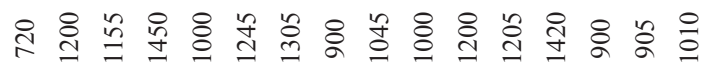
产

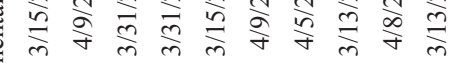

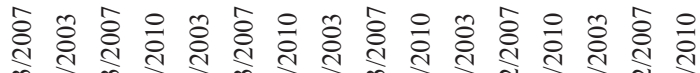

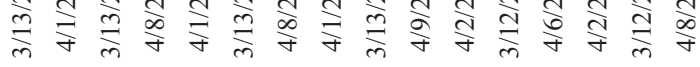

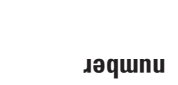
นо!̣อง!!!?uәр! SэSก

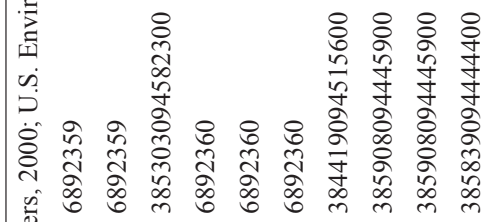

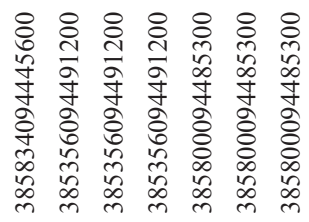

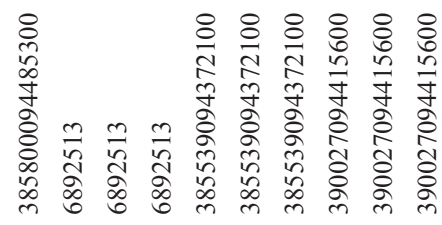<smiles>C1CCCCC1</smiles>

วuलu әฺ!

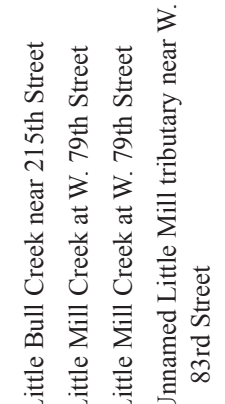

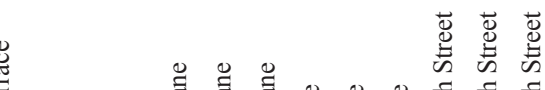

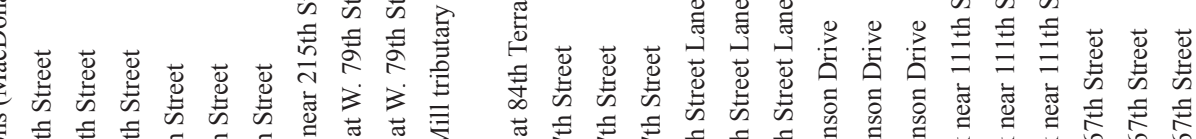

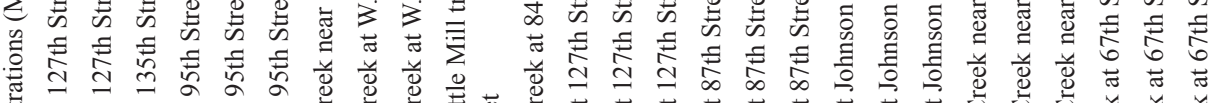

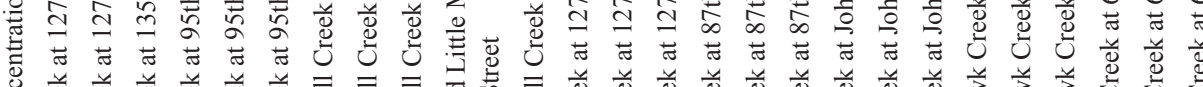

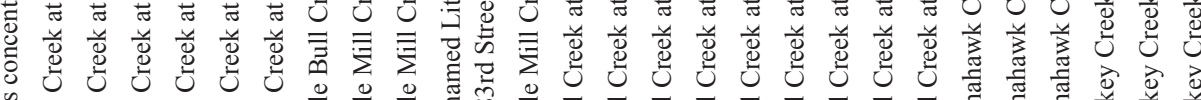

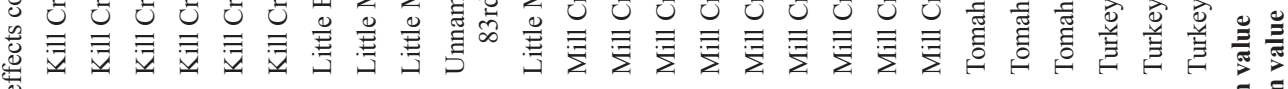




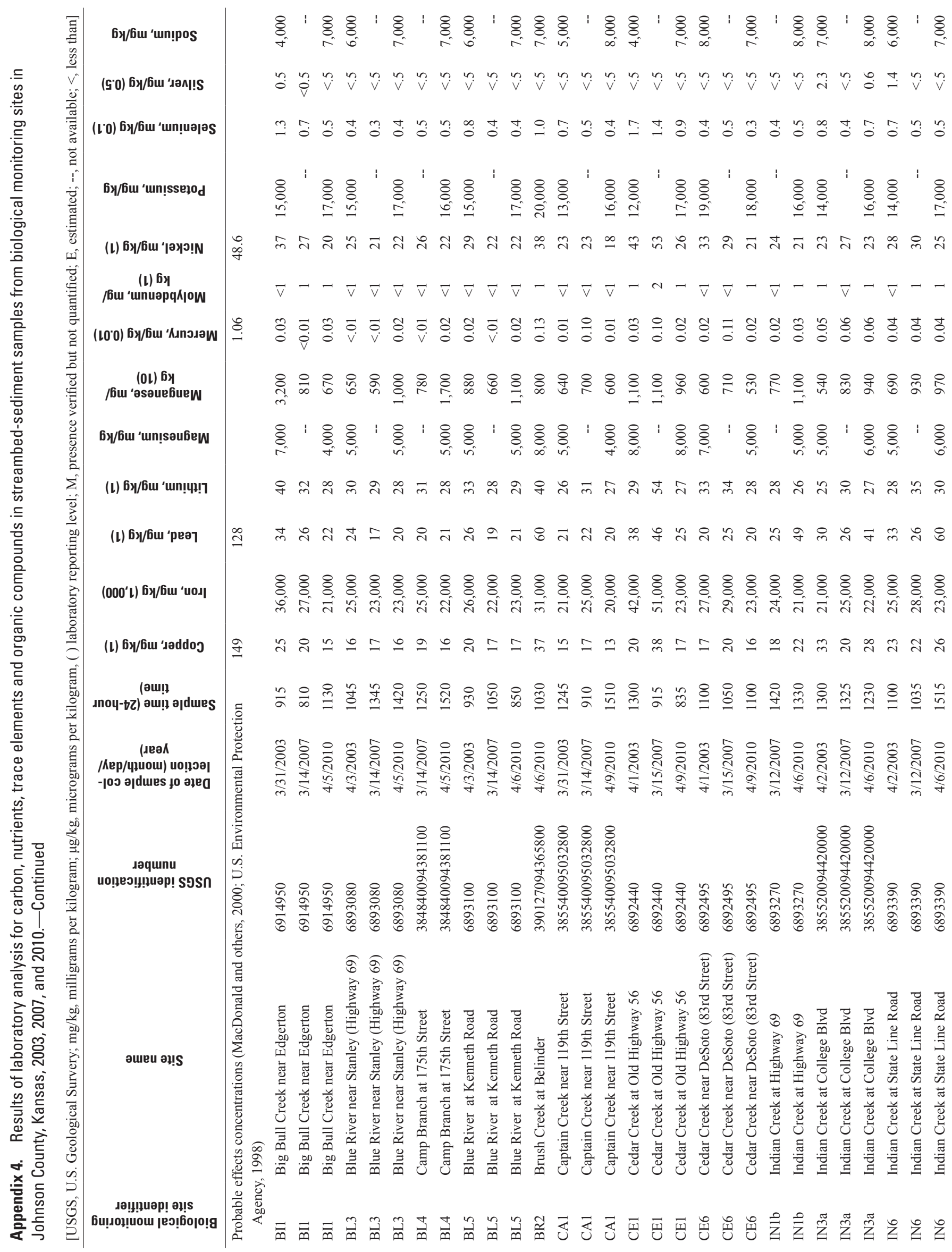




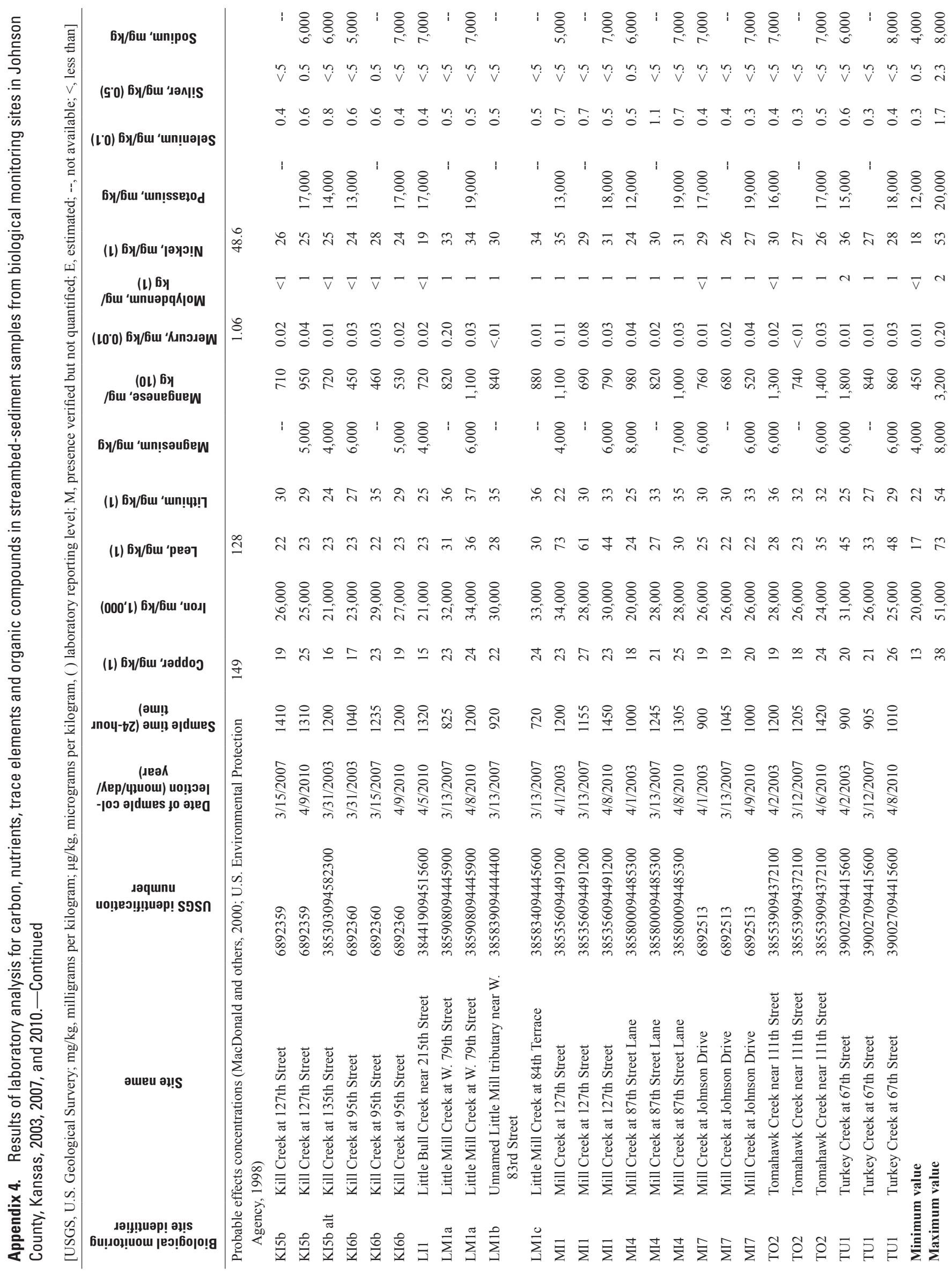




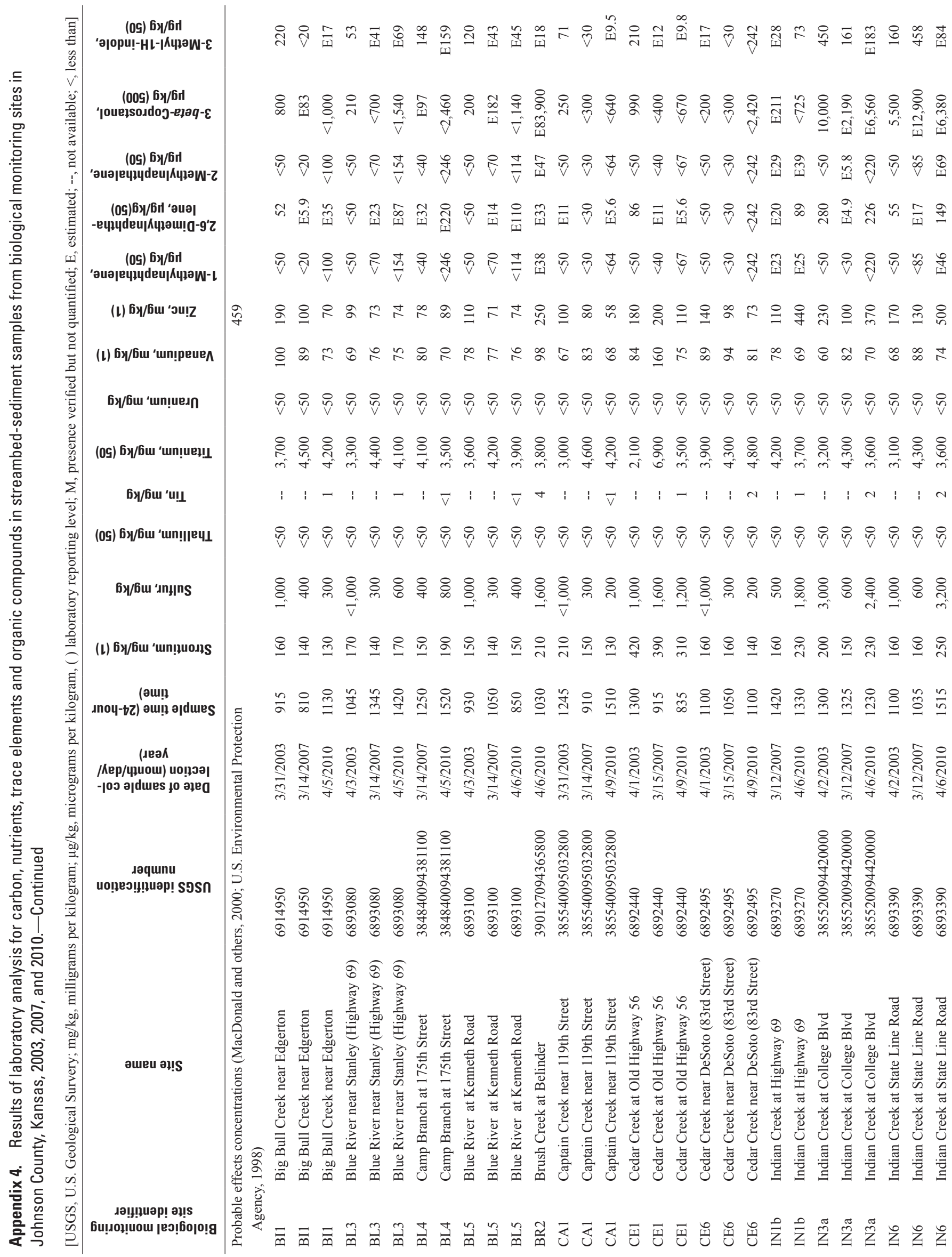




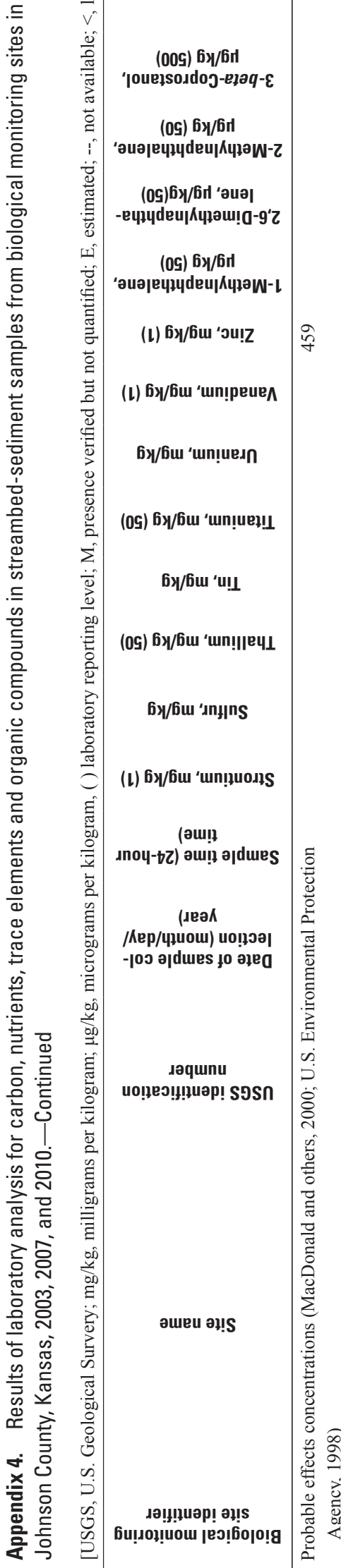

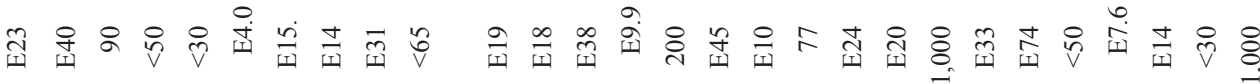

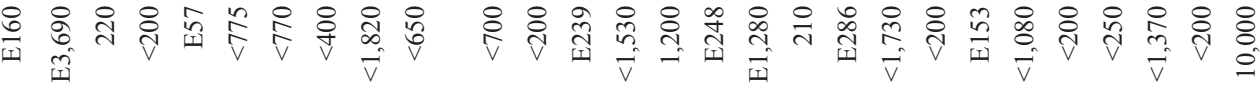

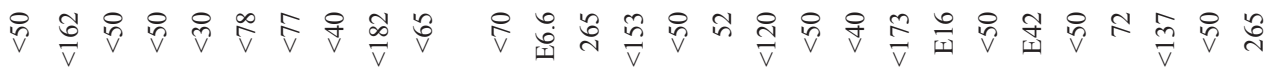

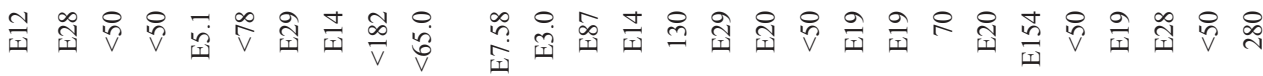

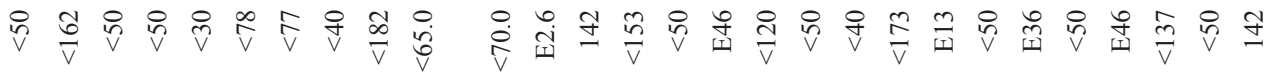

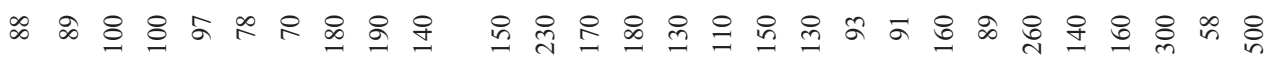

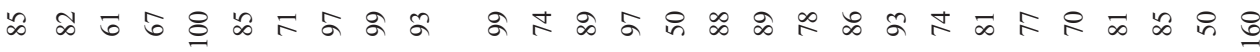

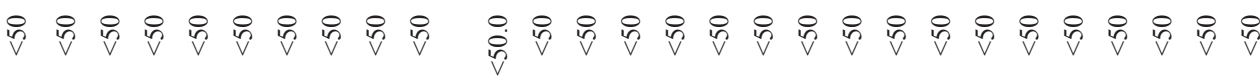

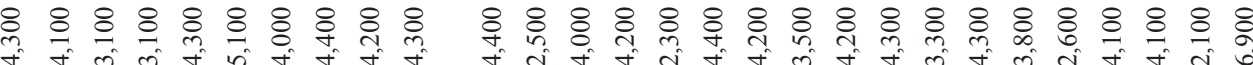

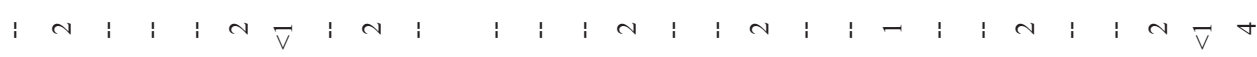

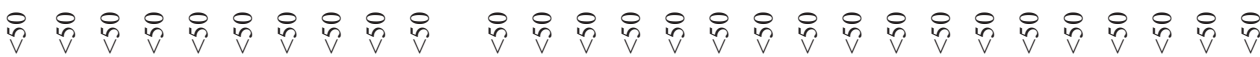

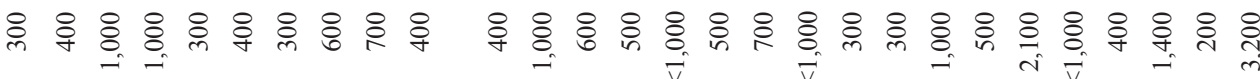

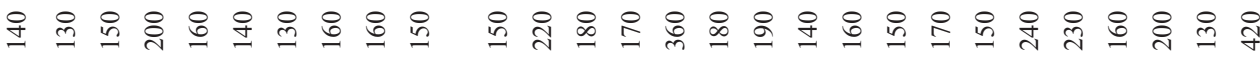

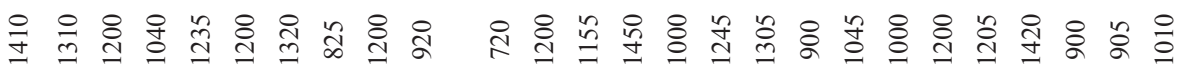

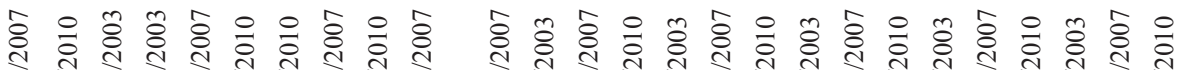

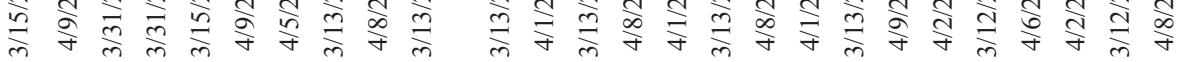

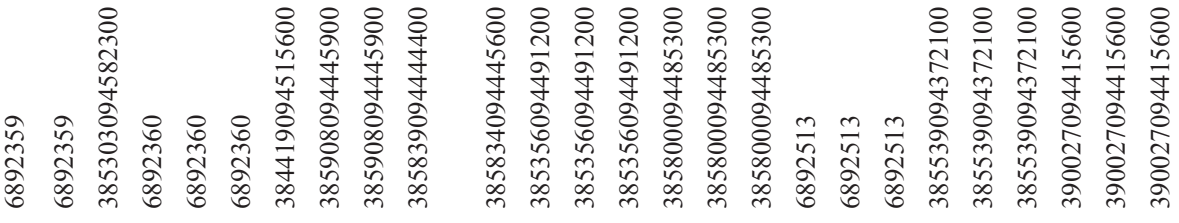

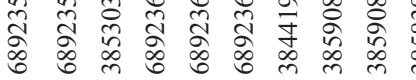

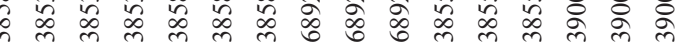

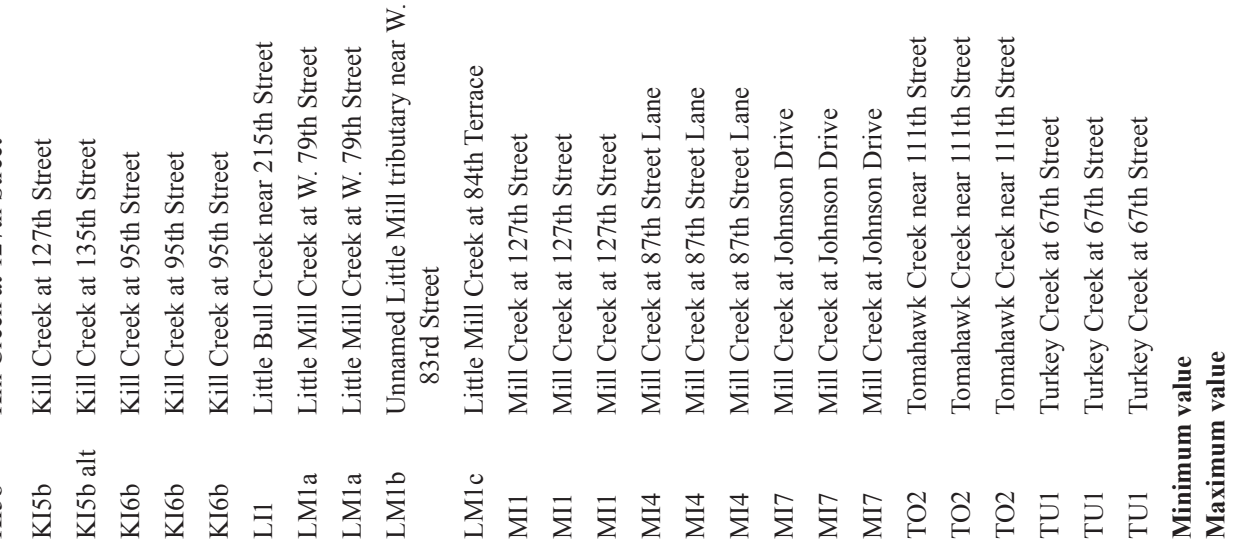




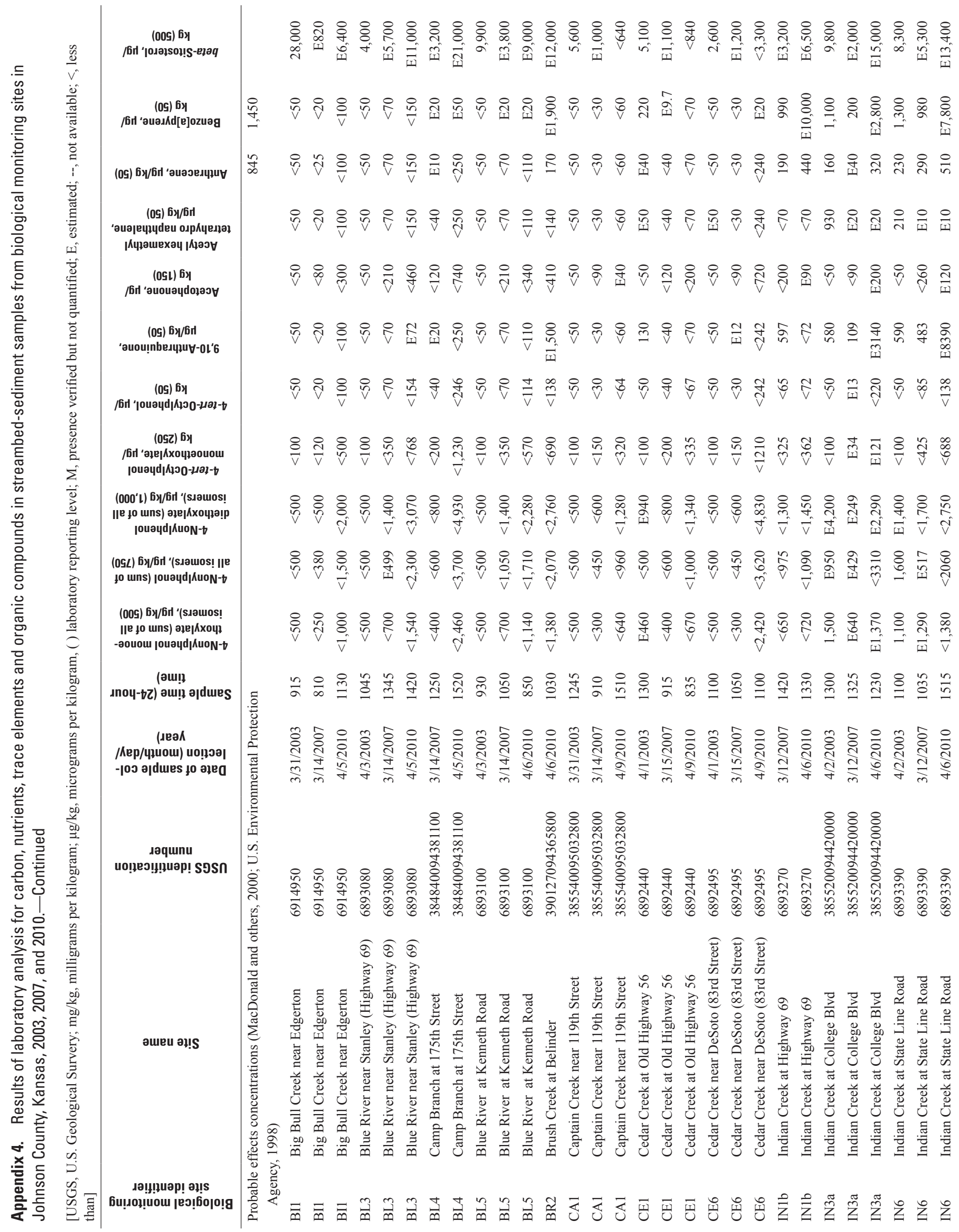




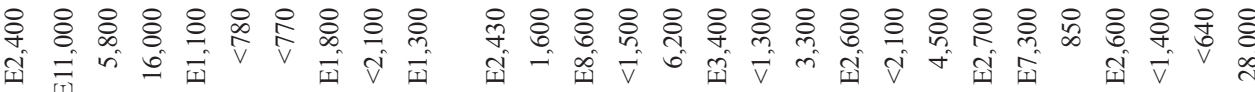

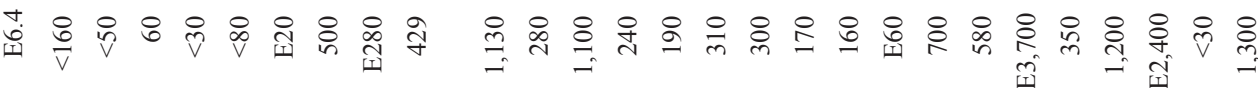
它家

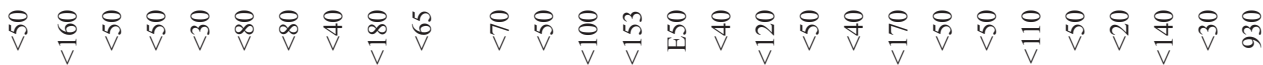
角 守

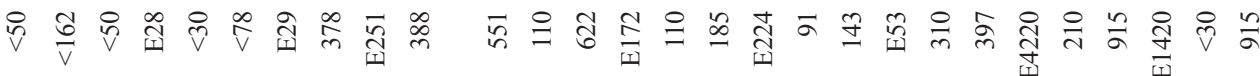

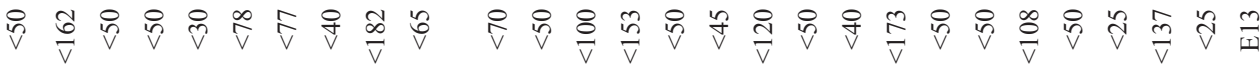

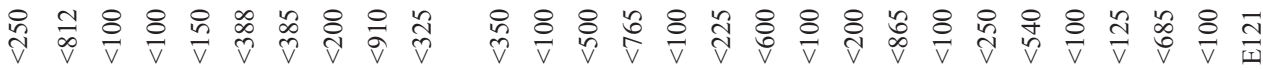

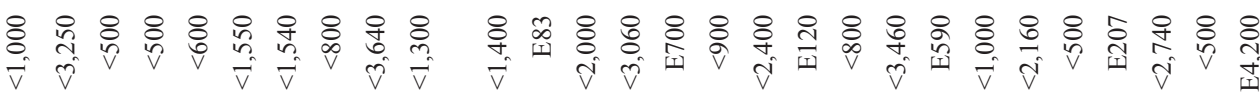

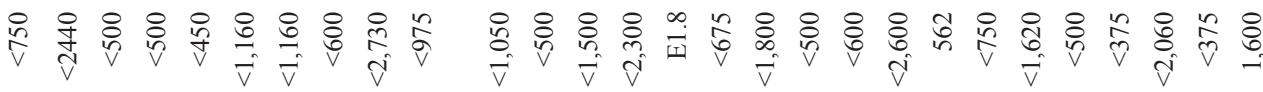

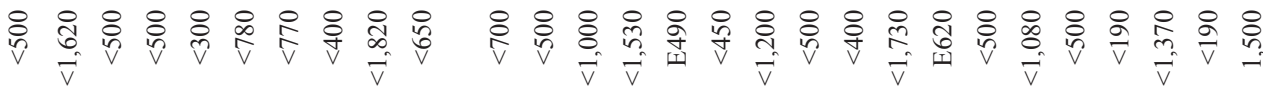

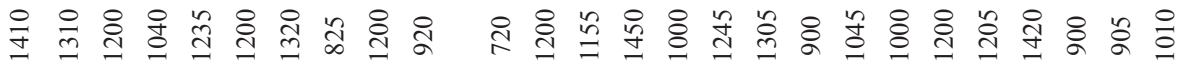

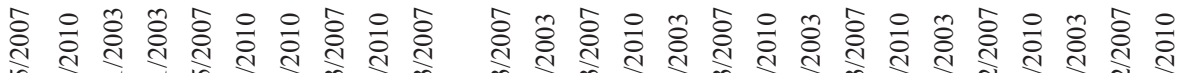
m

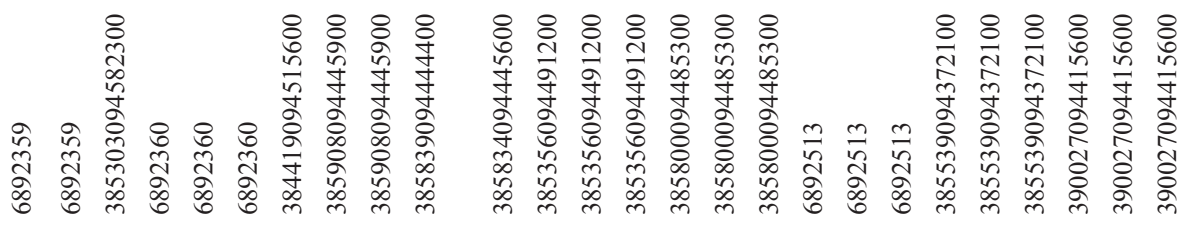

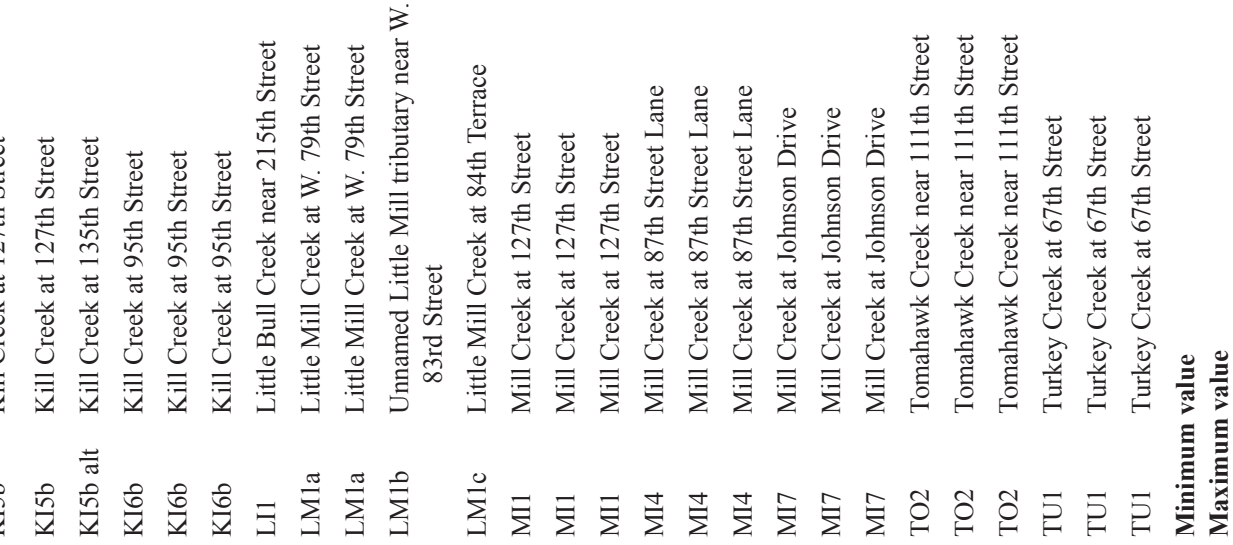




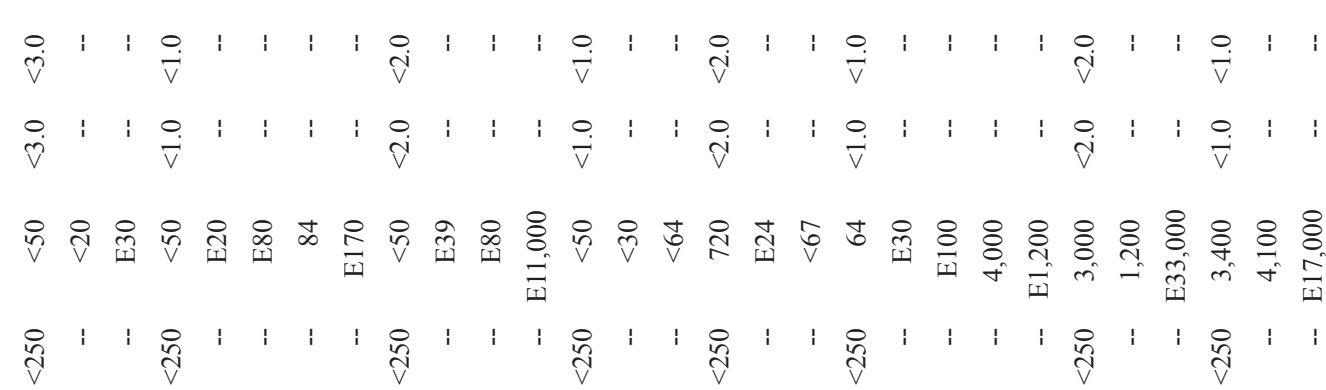

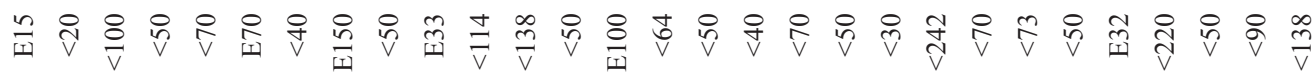

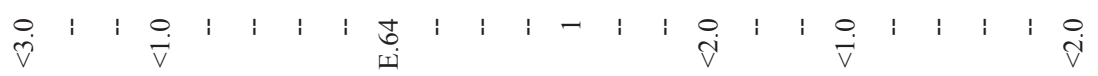

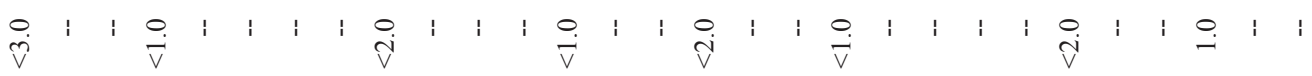

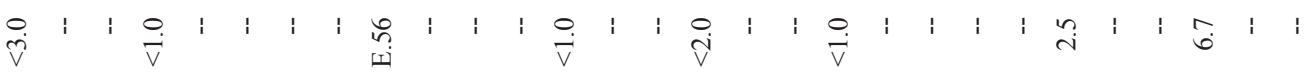
\& \& \& \& \& \& \& \& \& \& \& \&

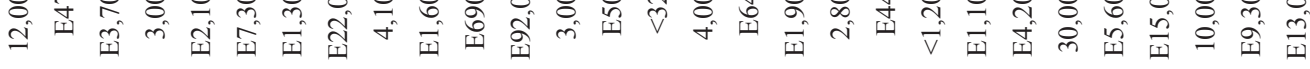

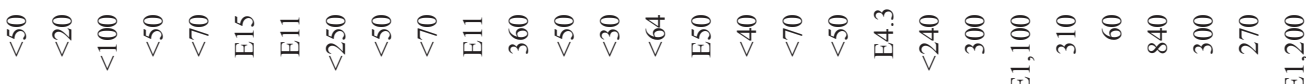
○'

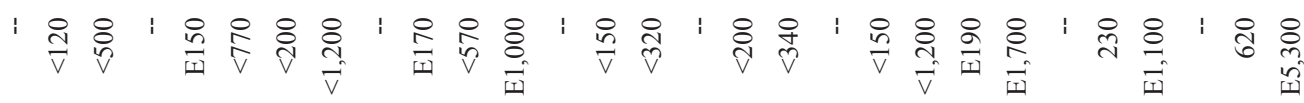

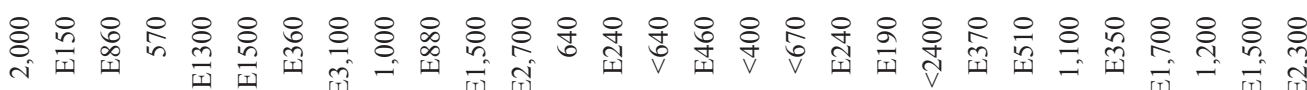

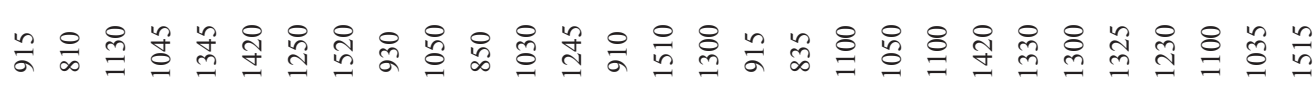

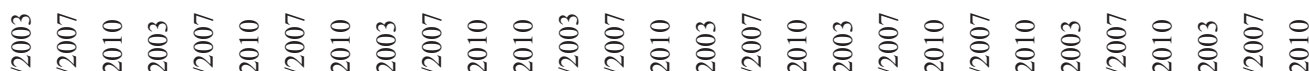

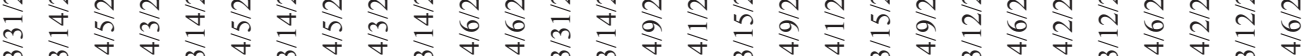

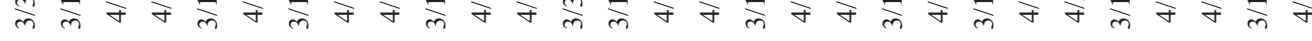

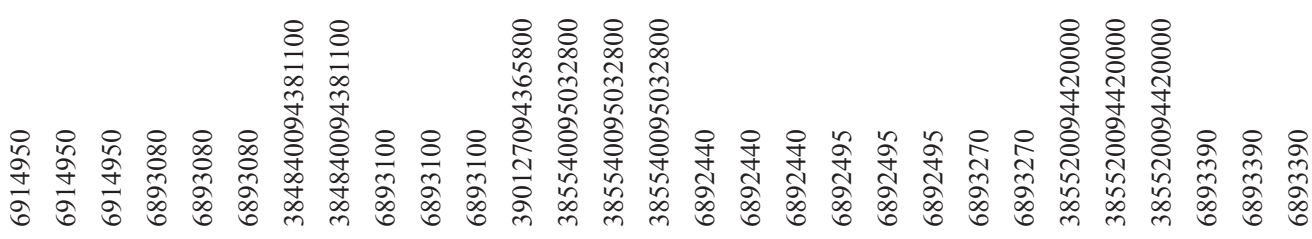

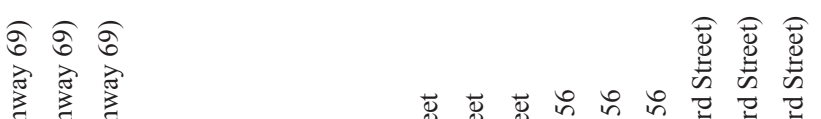

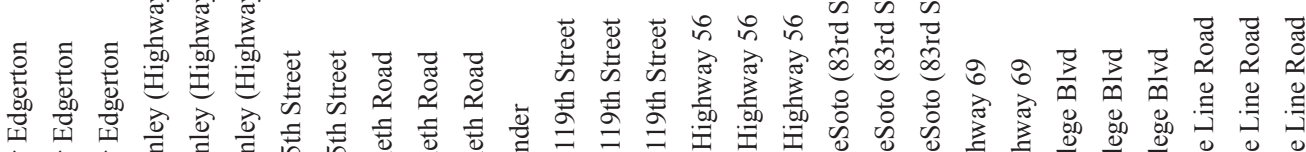

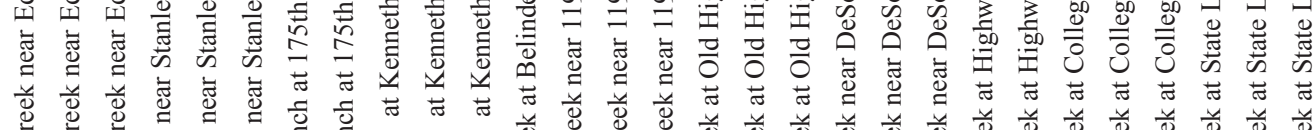

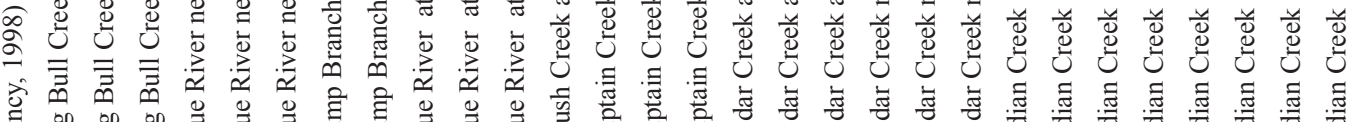
总 훙

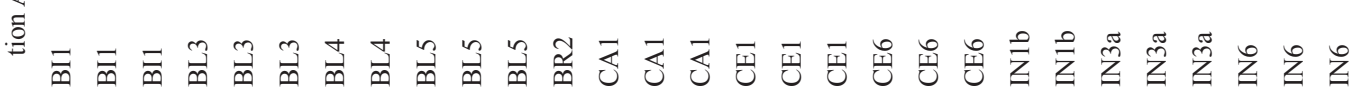




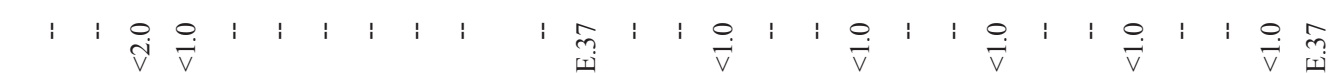

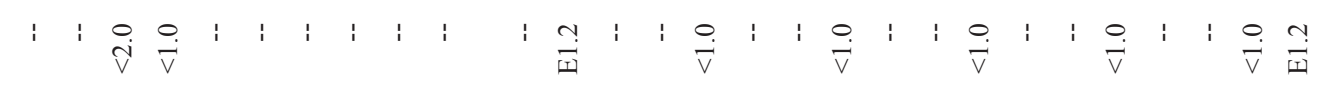

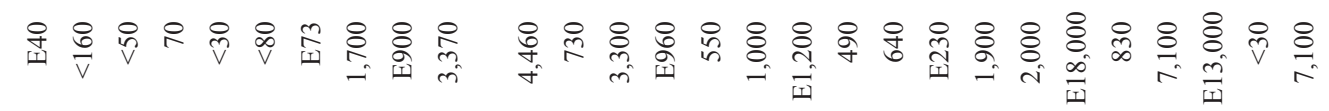

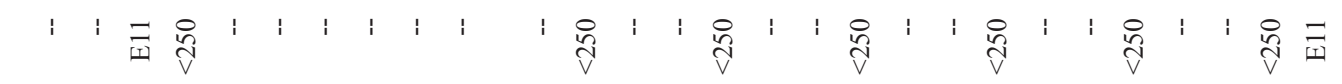

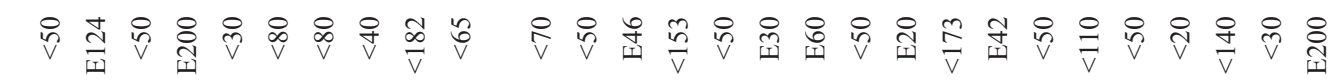

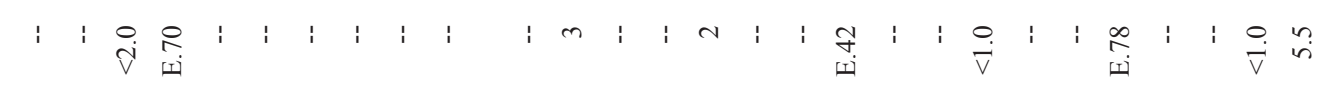

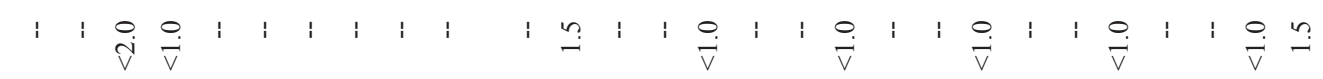

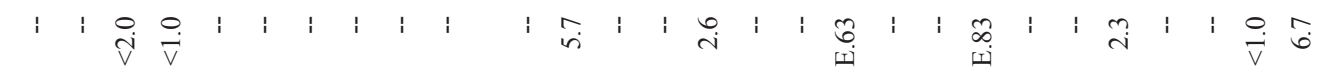

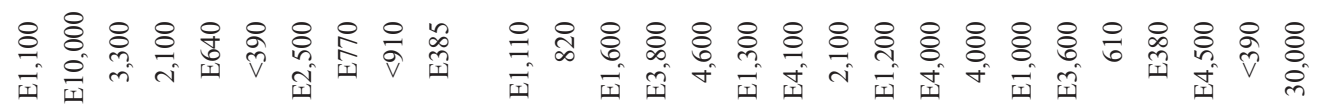
윈

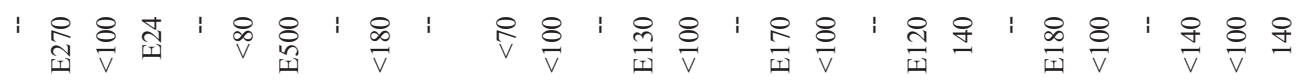

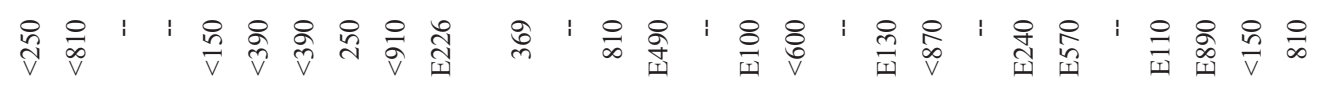

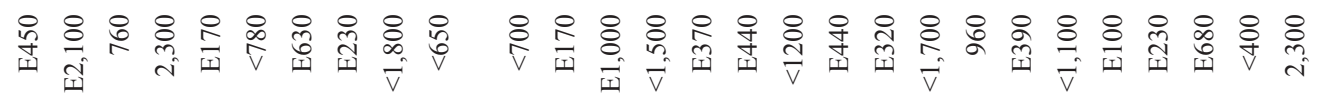

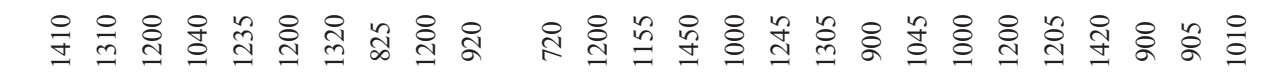

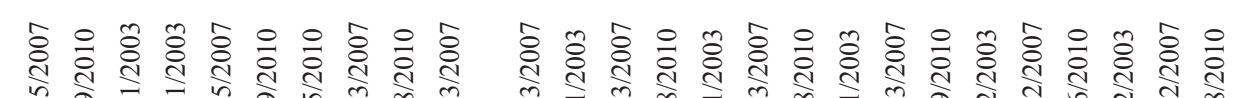

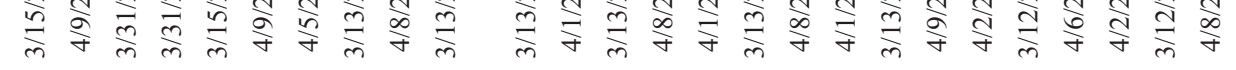

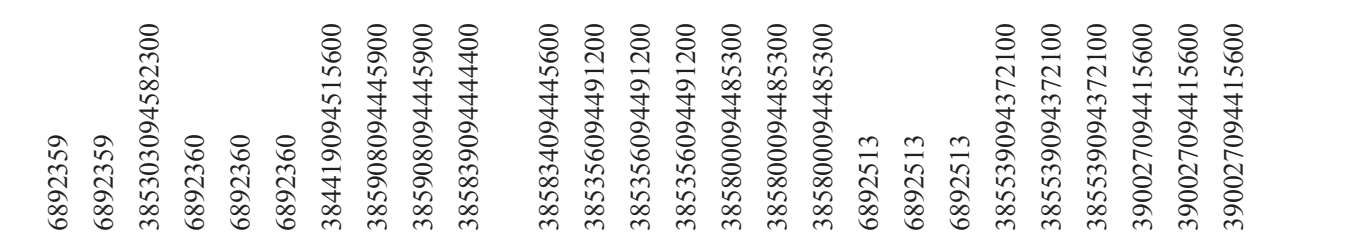
(1)

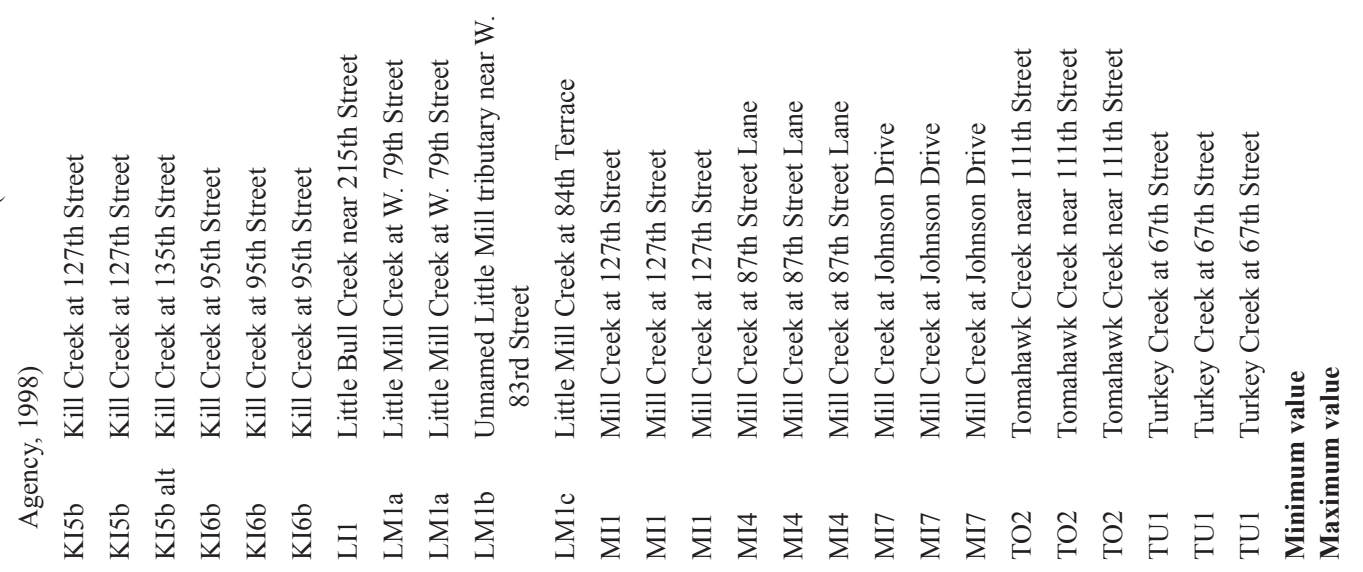




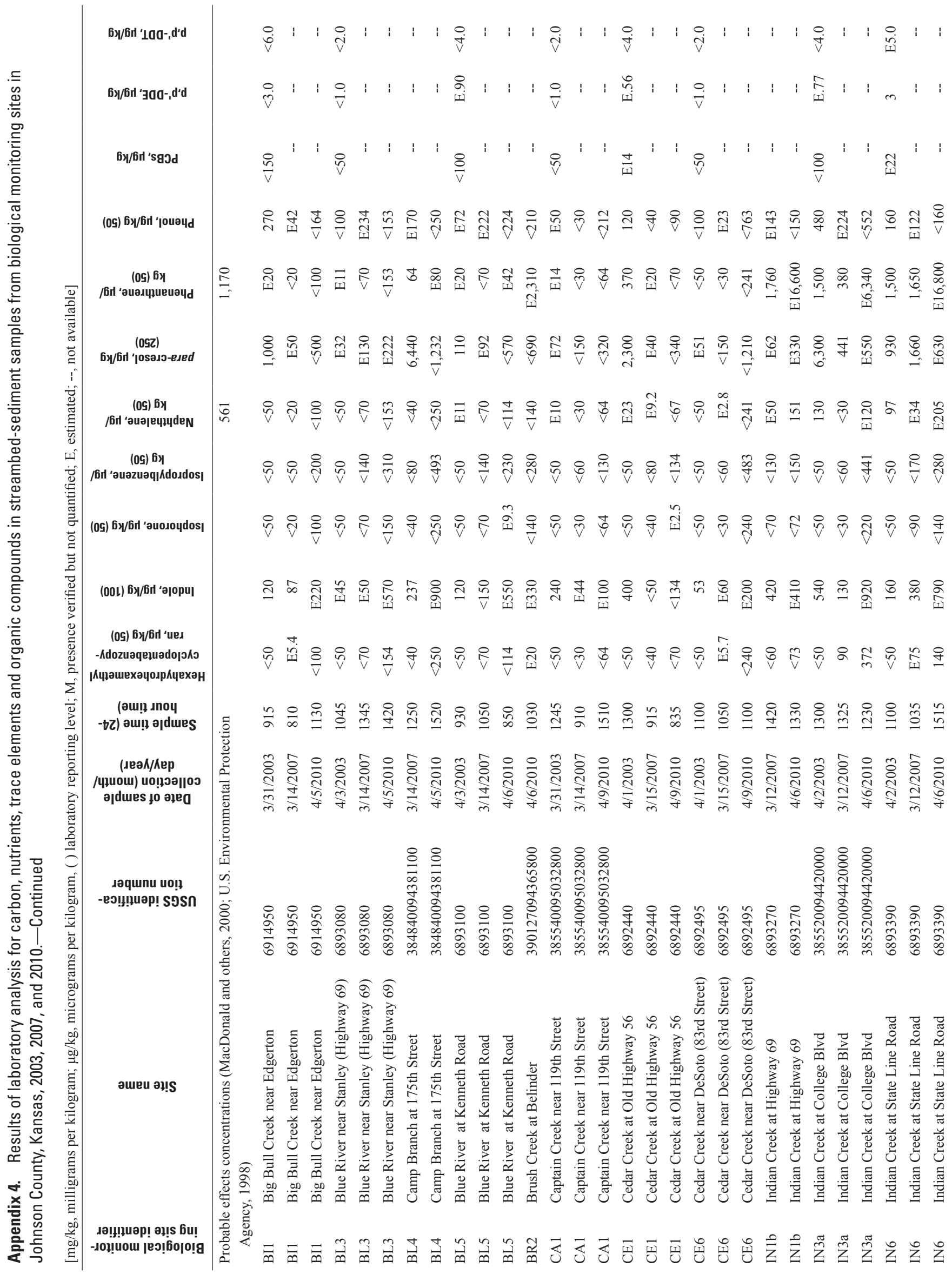




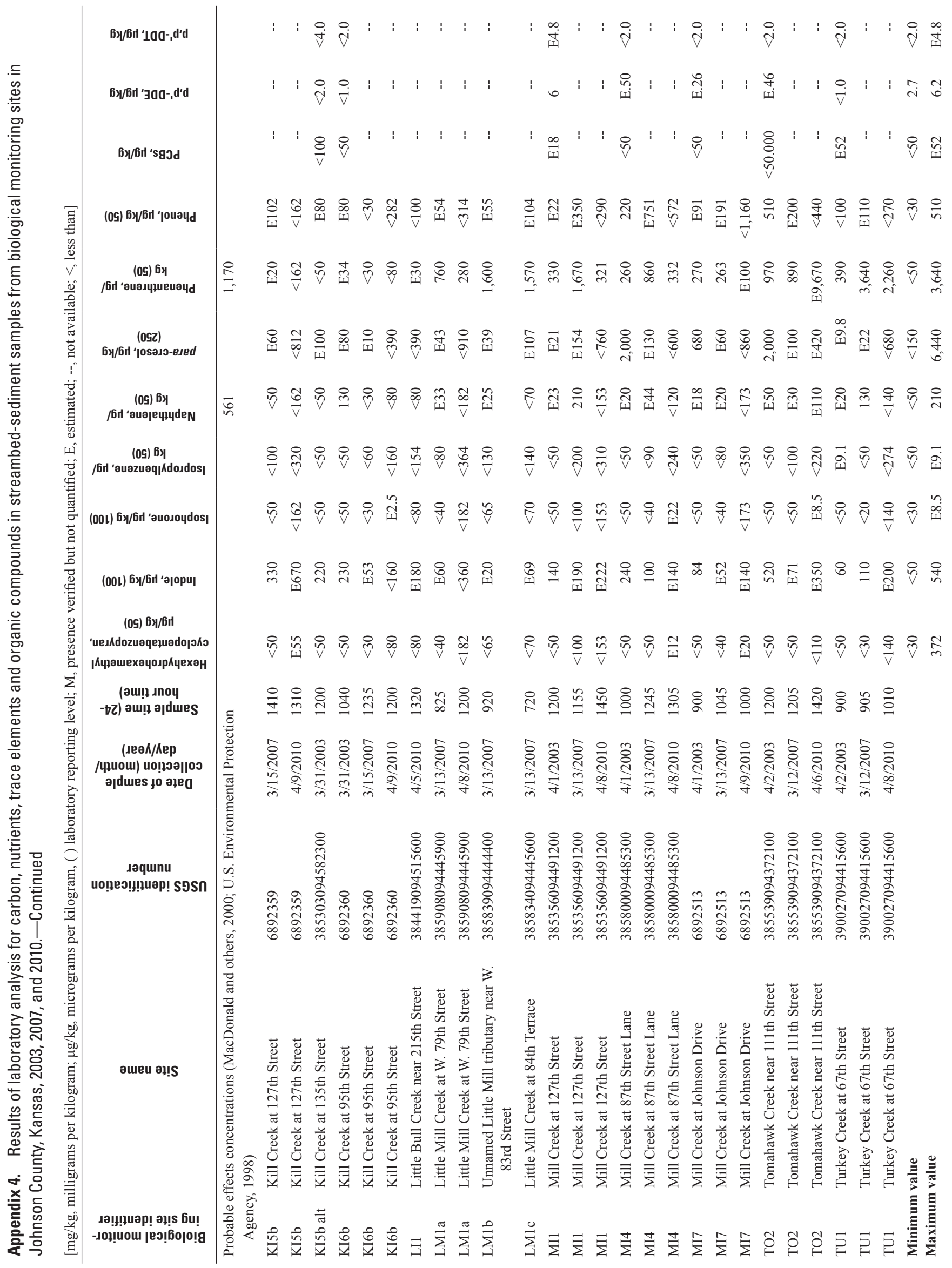




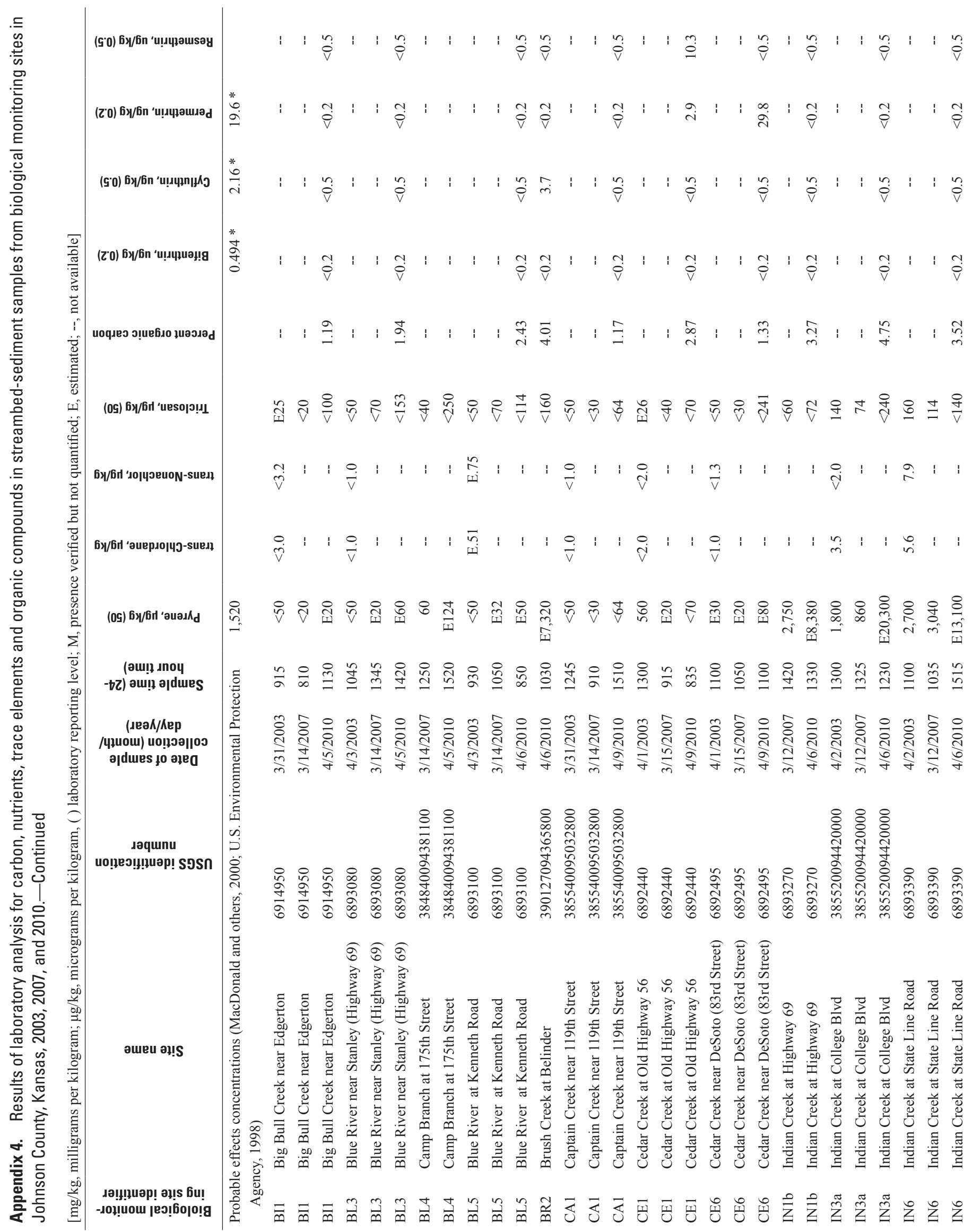



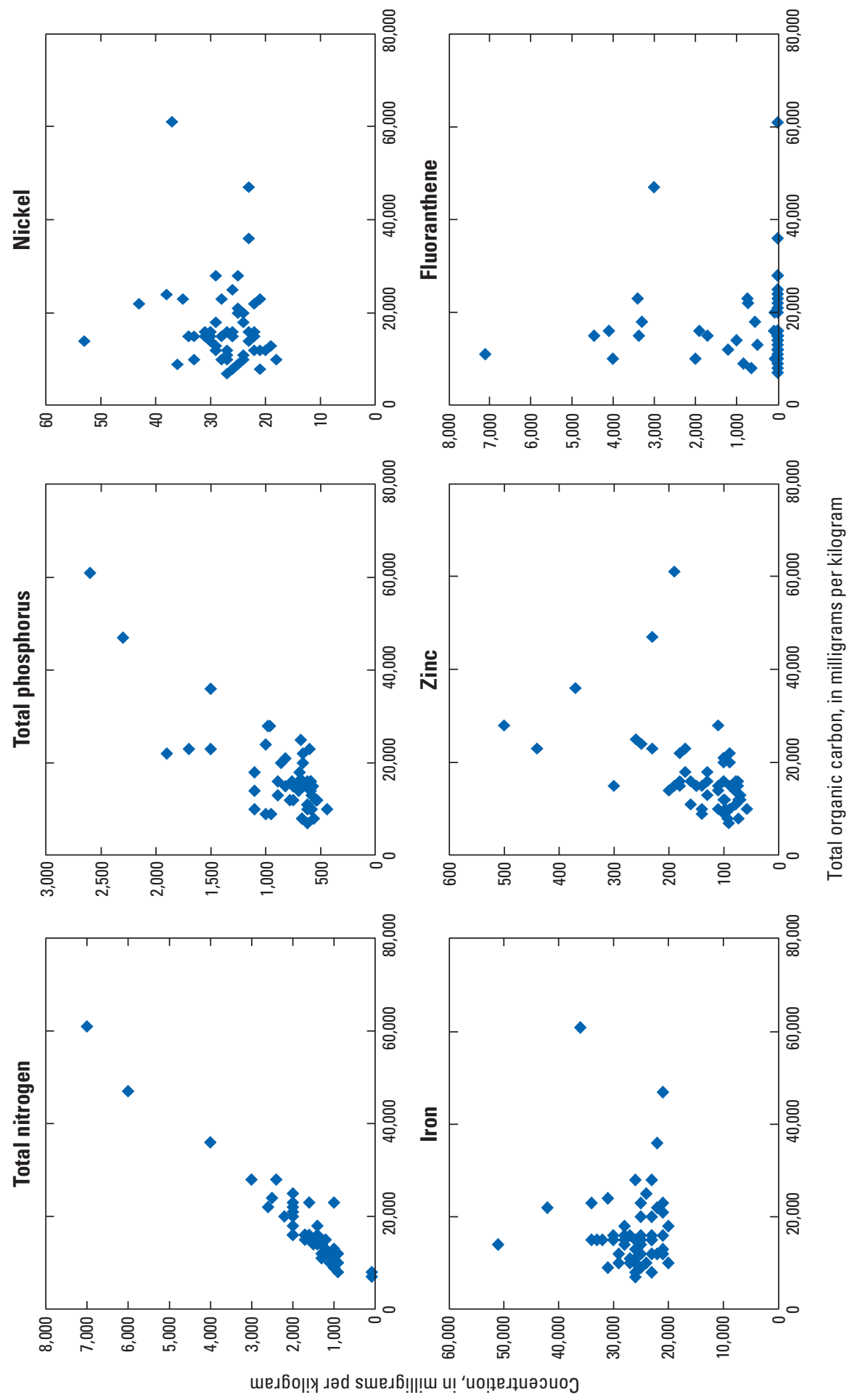
Appendix 6. Periphyton taxa identified and the number of biological monitoring sites where each taxa occurred in Johnson County, Kansas streams during April 2010.

[Bacillariophyta, diatoms; Chlorophyta, green algae; Chrysophyta, golden algae; Cynophyta, blue-green algae or cyanobacteria; Euglenophyta, euglenoids; Rhodophyta, red algae; Streptophyta, green plants; sp., species; var., variety]

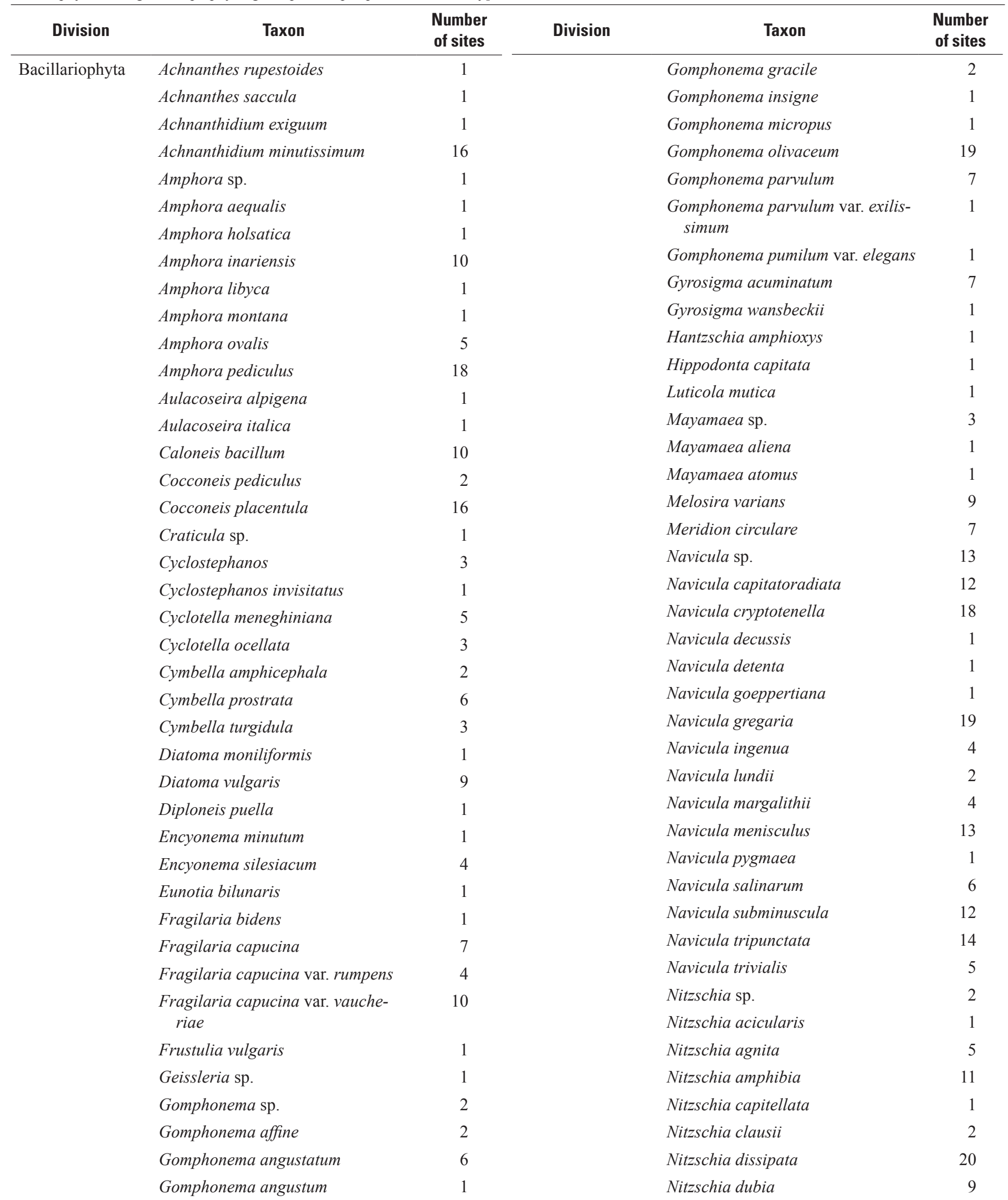


Appendix 6. Periphyton taxa identified and the number of biological monitoring sites where each taxa occurred in Johnson County, Kansas streams during April 2010.-Continued

[Bacillariophyta, diatoms; Chlorophyta, green algae; Chrysophyta, golden algae; Cynophyta, blue-green algae or cyanobacteria; Euglenophyta, euglenoids; Rhodophyta, red algae; Streptophyta, green plants; sp., species; var., variety]

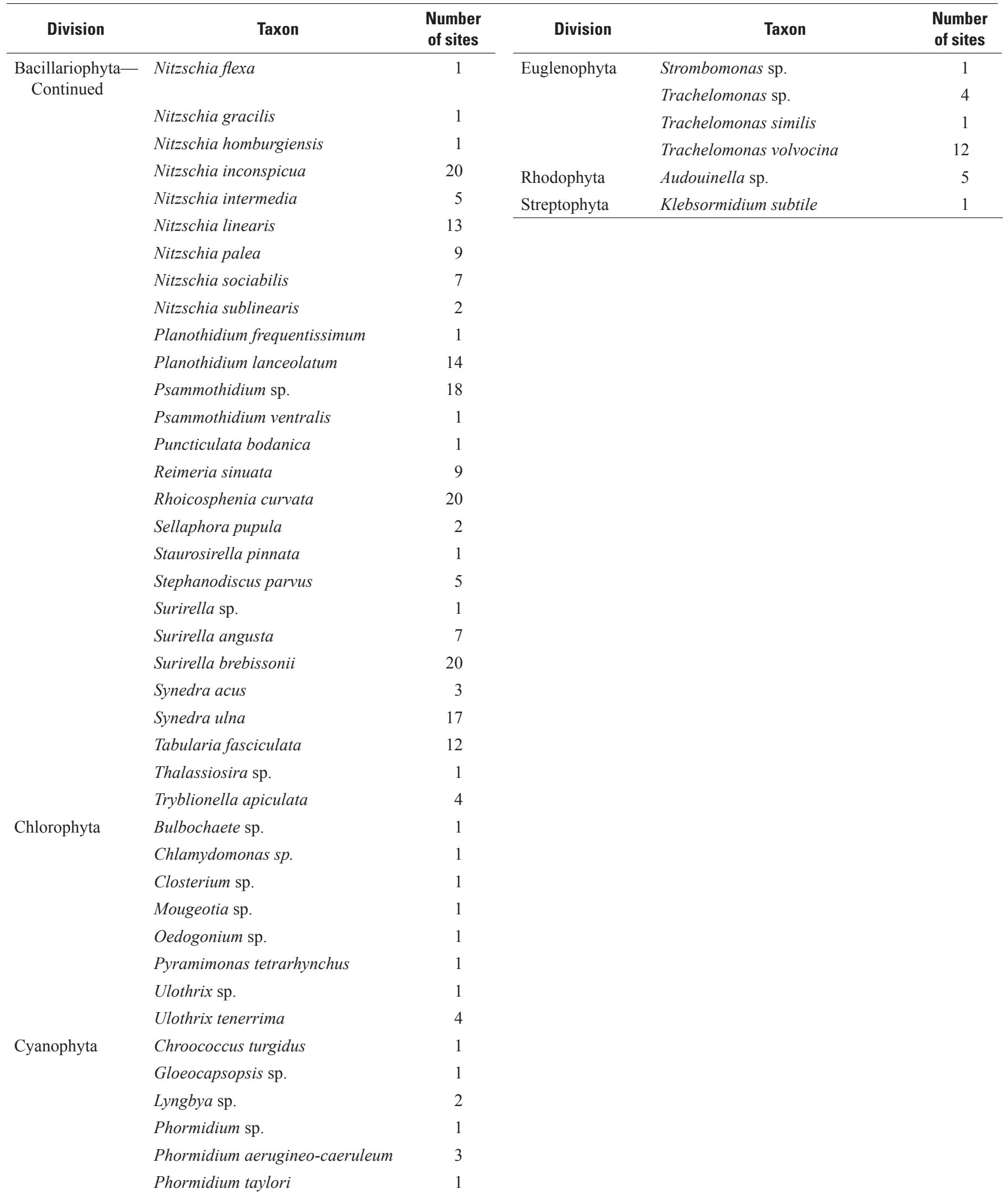


Appendix 7. Four most dominant periphyton taxa on the basis of abundance and the percentage contribution of each taxon to total abundance at biological monitoring sites in Johnson County, Kansas, during April 2010.

[sp., species; var., variety; total percentage does not always equal sum of species percentages because of rounding effects]

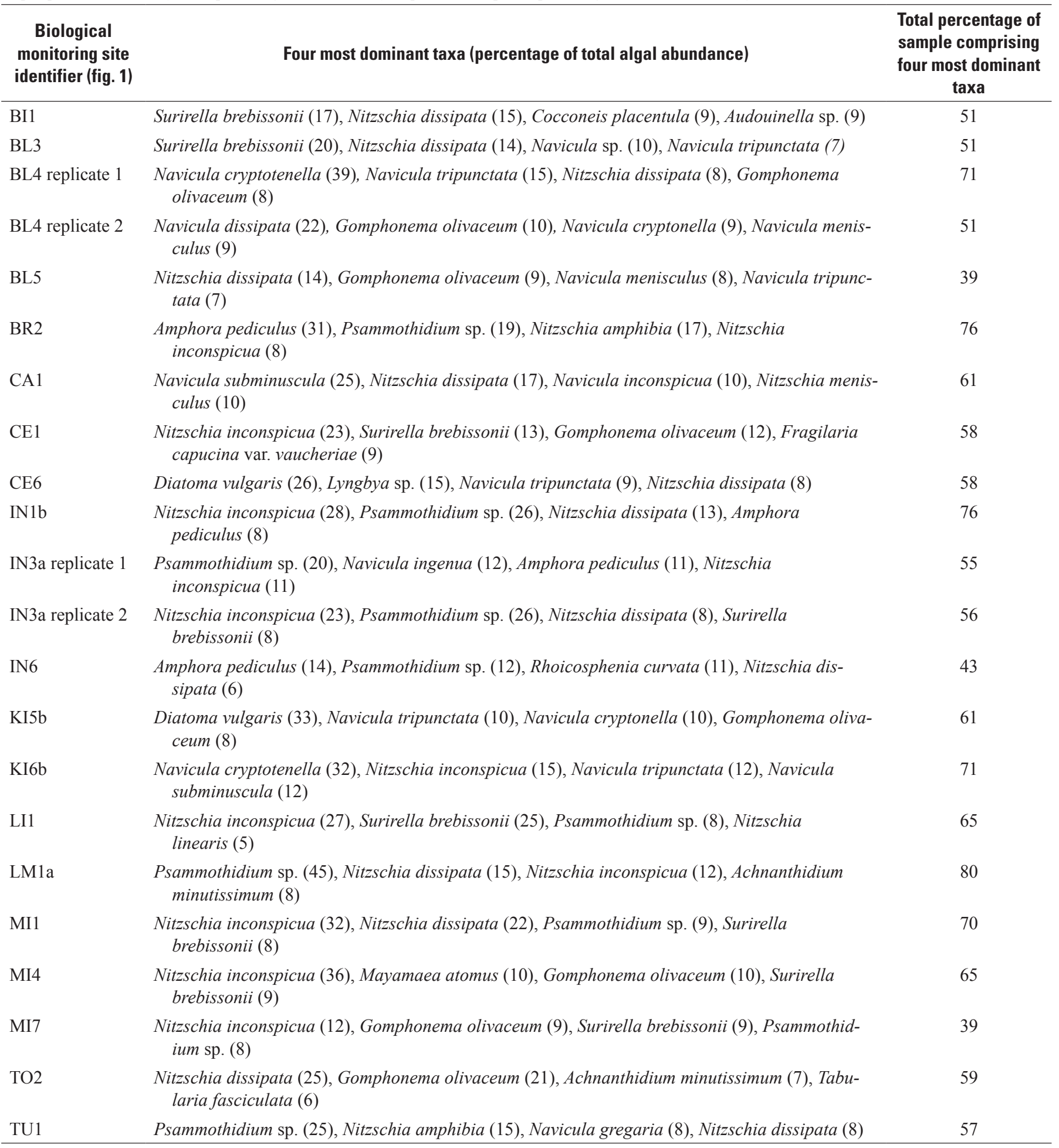


Appendix 8. Four most dominant periphyton taxa on the basis of biovolume and the percentage contribution of each taxon to total biovolume at biological monitoring sites in Johnson County, Kansas, during April 2010.

[sp., species; total percentage does not always equal sum of species percentages because of rounding effects]

\begin{tabular}{|c|c|c|}
\hline $\begin{array}{c}\text { Biological } \\
\text { monitoring site } \\
\text { identifier (fig. 1) }\end{array}$ & Four most dominant taxa (percentage of total algal abundance) & $\begin{array}{c}\text { Total percentage of } \\
\text { sample comprising } \\
\text { four most dominant } \\
\text { taxa }\end{array}$ \\
\hline BI1 & Surirella brebissonii (32), Cocconeis placentula (21), Synedra ulna (17), Nitzschia dissipata (6) & 76 \\
\hline BL3 & $\begin{array}{l}\text { Diatoma vulgaris (17), Surirella brebissonii (15), Nitzschia linearis (15), Navicula } \\
\text { tripunctata (15) }\end{array}$ & 62 \\
\hline BL4 replicate 2 & Synedra ulna (36), Navicula tripunctata (15), Gomphonema olivaceum (10), Nitzschia linearis (8) & 69 \\
\hline BL5 & $\begin{array}{l}\text { Navicula tripunctata (12), Diatoma vulgaris (12), Cocconeis placentula (11), Melosira } \\
\quad \text { varians (10) }\end{array}$ & 45 \\
\hline BR2 & $\begin{array}{l}\text { Navicula gregaria (22), Surirella brebissonii (19), Psammothidium sp. (12), Nitzschia } \\
\text { amphibia (9) }\end{array}$ & 61 \\
\hline CE1 & $\begin{array}{l}\text { Surirella brebissonii (21), Cocconeis placentula (12), Synedra ulna (10), Gomphonema } \\
\text { olivaceum (9) }\end{array}$ & 51 \\
\hline CE6 & Diatoma vulgaris (52), Navicula tripunctata (17), Synedra ulna (9), Melosira varians (5) & 83 \\
\hline IN1b & $\begin{array}{l}\text { Nitzschia dissipata (34), Rhoicosphenia curvata (9), Surirella brebissonii (8), Gyrosigma acumi- } \\
\text { natum (8) }\end{array}$ & 59 \\
\hline IN3a replicate 1 & Surirella brebissonii (20), Mougeotia sp. (19), Nitzschia dubia (10), Navicula tripunctata (9) & 59 \\
\hline IN3a replicate 2 & $\begin{array}{l}\text { Surirella brebissonii (16), Gyrosigma acuminatum (15), Melosira varians (15), Nitzschia } \\
\quad \text { dubia (8) }\end{array}$ & 54 \\
\hline IN6 & $\begin{array}{l}\text { Surirella brebissonii (23), Rhoicosphenia curvata (16), Melosira varians (10), Navicula tripunc- } \\
\quad \text { tata (7) }\end{array}$ & 55 \\
\hline MI1 & $\begin{array}{l}\text { Surirella brebissonii (37), Nitzschia dissipata (28), Nitzschia inconspicua (6), Gomphonema } \\
\text { olivaceum (5) }\end{array}$ & 76 \\
\hline MI4 & $\begin{array}{l}\text { Surirella brebissonii (25), Synedra ulna (19), Nitzschia intermedia (14), Gomphonema } \\
\quad \text { olivaceum (7) }\end{array}$ & 66 \\
\hline MI7 & Synedra ulna (34), Navicula margalithii (11), Nitzschia dubia (7), Nitzschia linearis (6) & 58 \\
\hline TO2 & $\begin{array}{l}\text { Nitzschia linearis (21), Gomphonema olivaceum (18), Nitzschia dissipata (13), Tabularia fascicu- } \\
\quad \text { lata (11) }\end{array}$ & 63 \\
\hline TU1 & $\begin{array}{l}\text { Surirella brebissonii (23), Navicula gregaria (7), Rhoicosphenia curvata (7), Nitzschia } \\
\quad \text { amphibia (7) }\end{array}$ & 43 \\
\hline
\end{tabular}




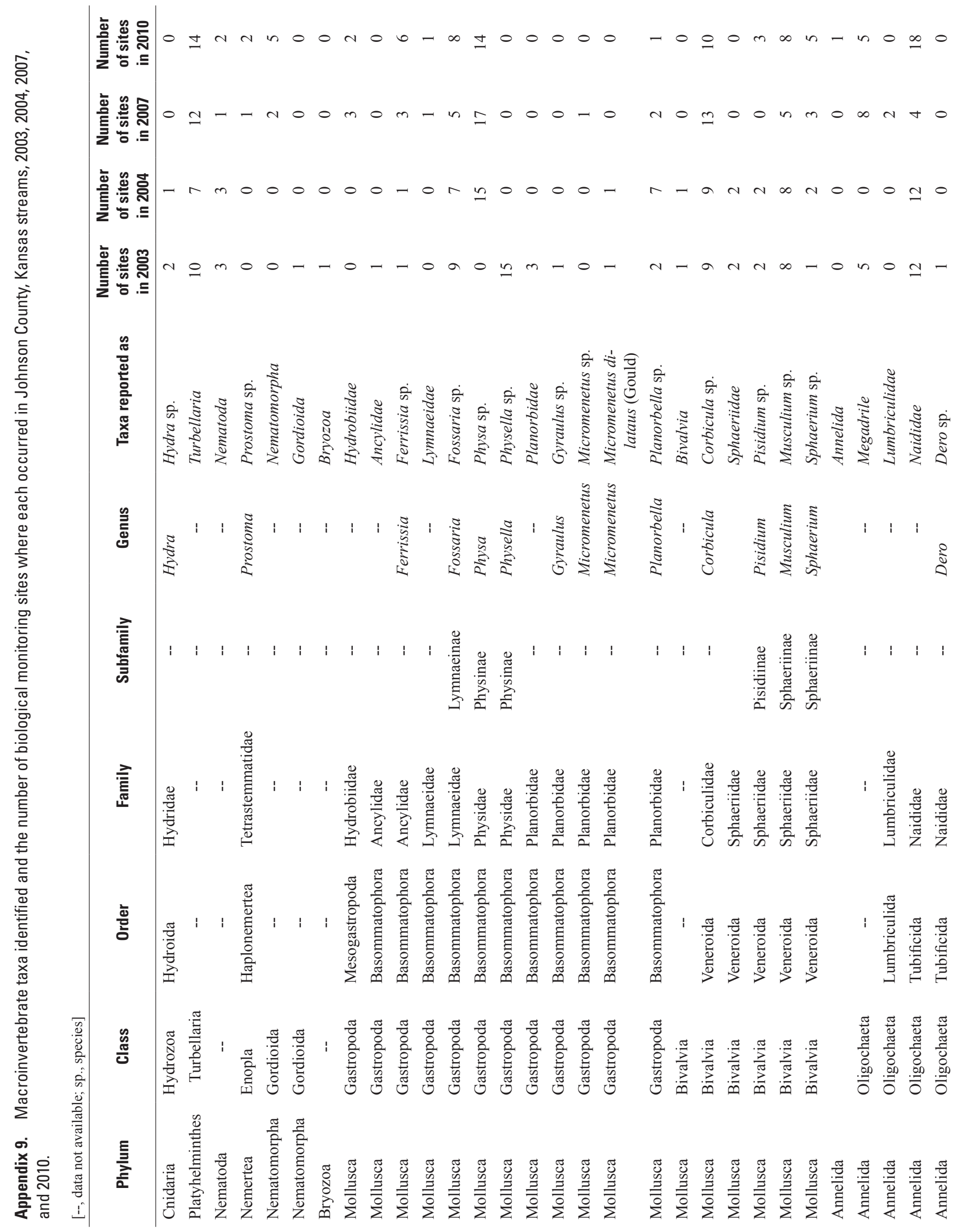




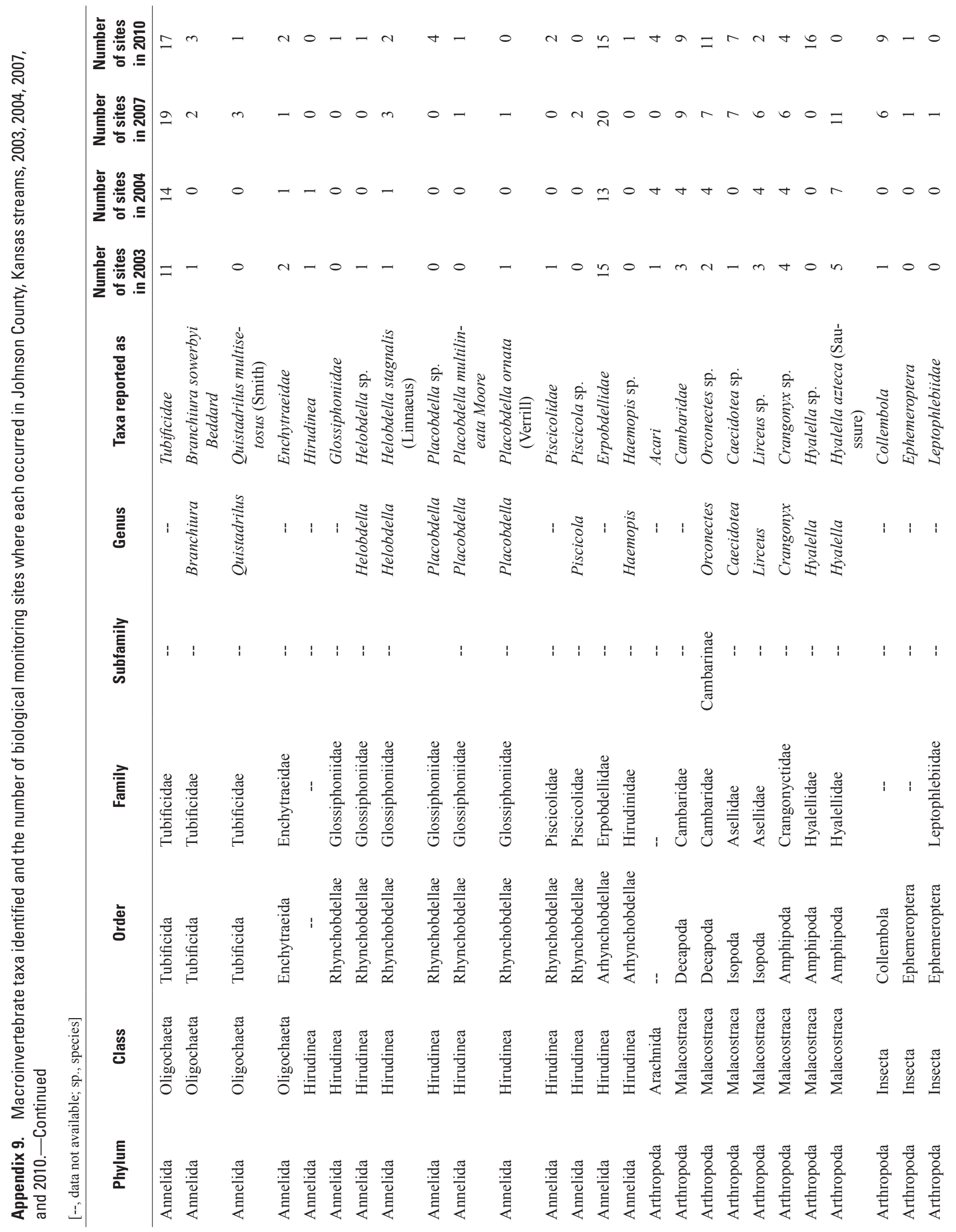




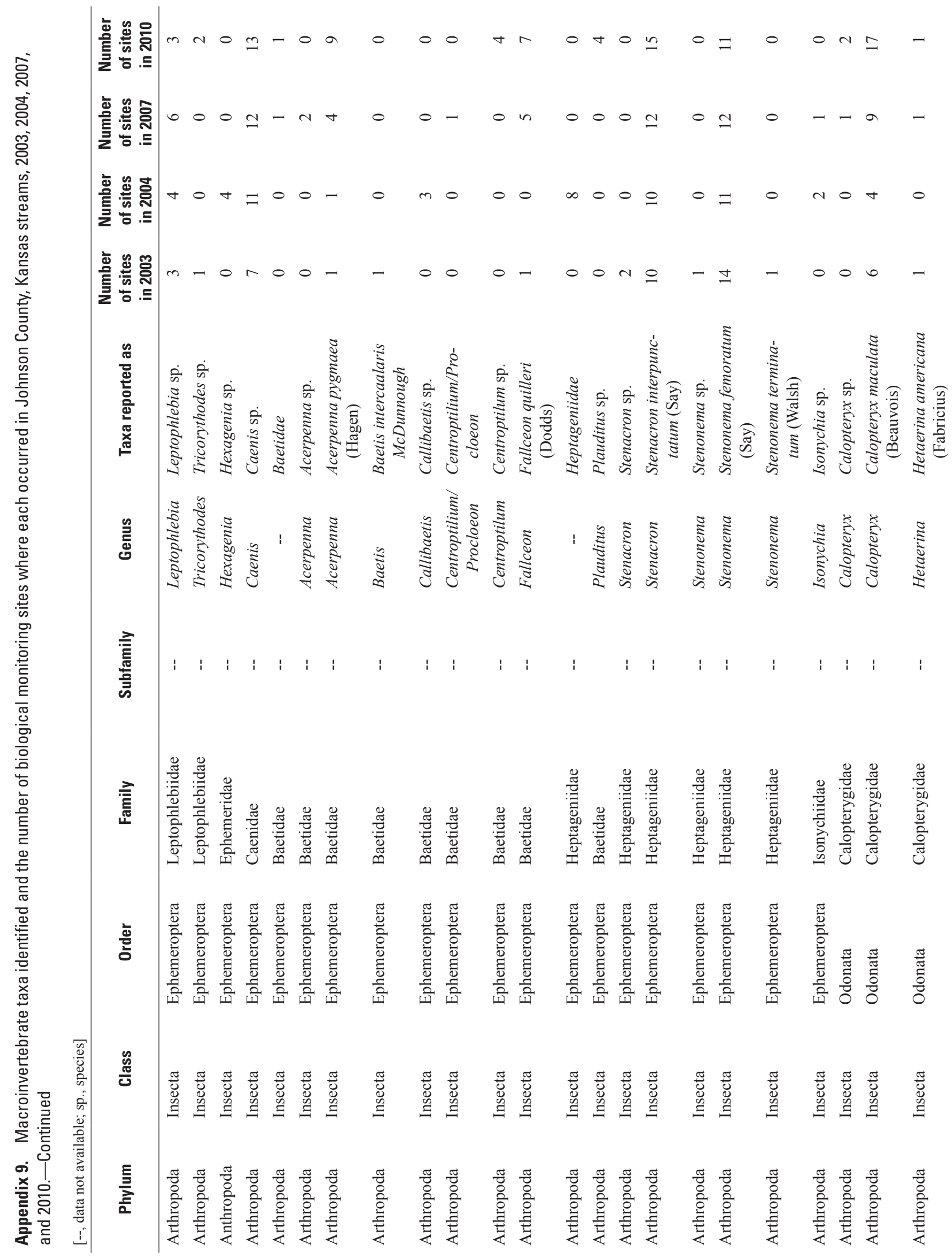




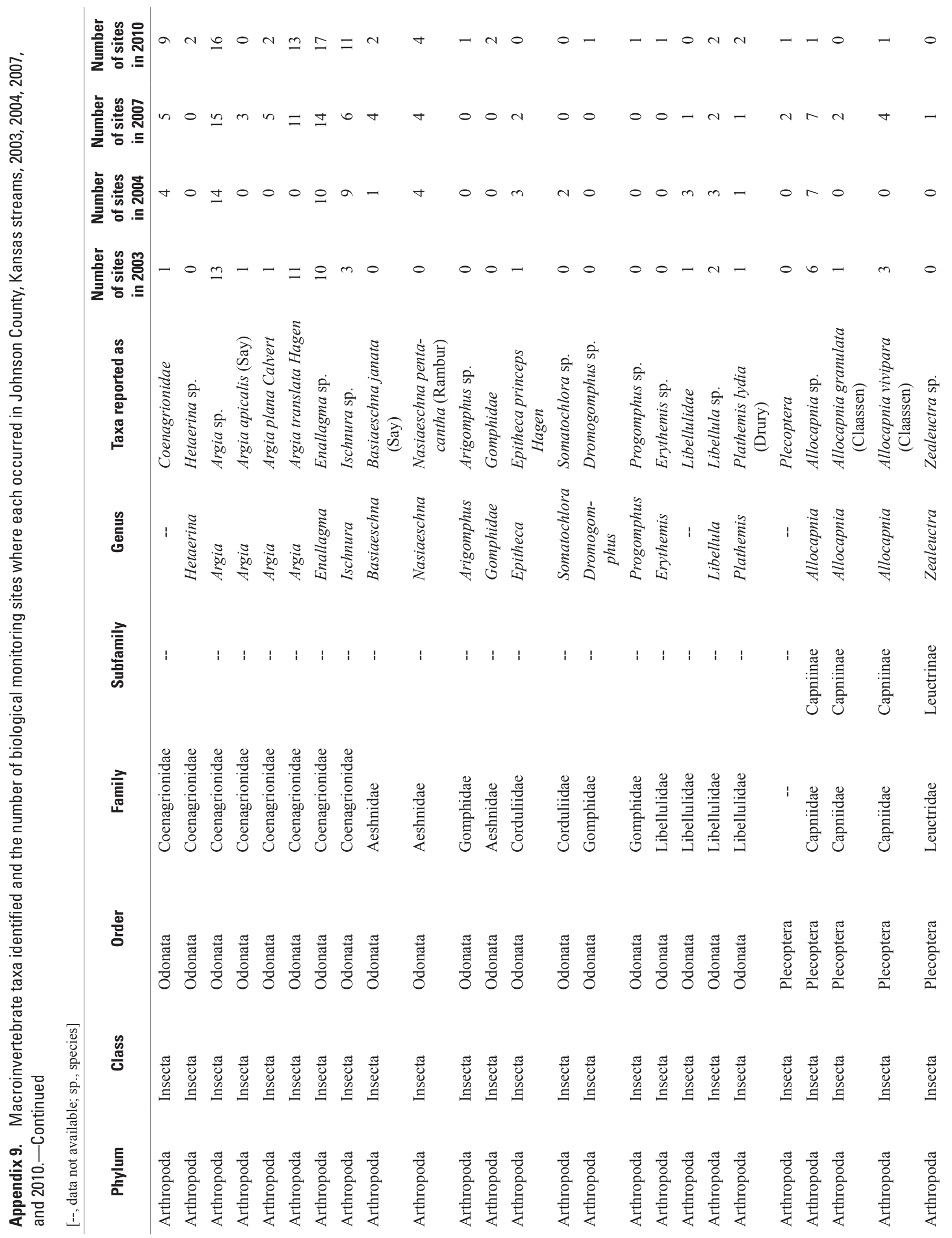




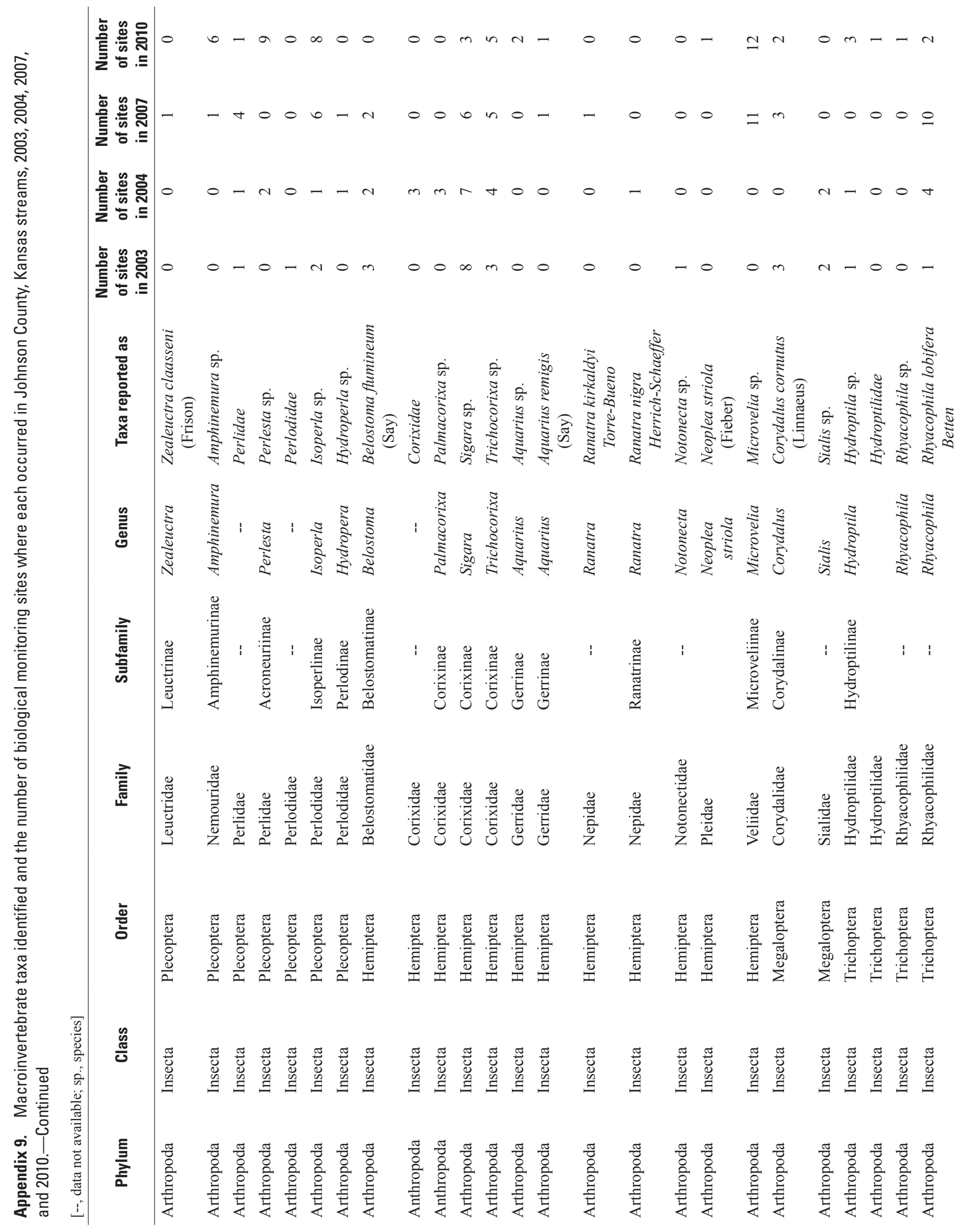




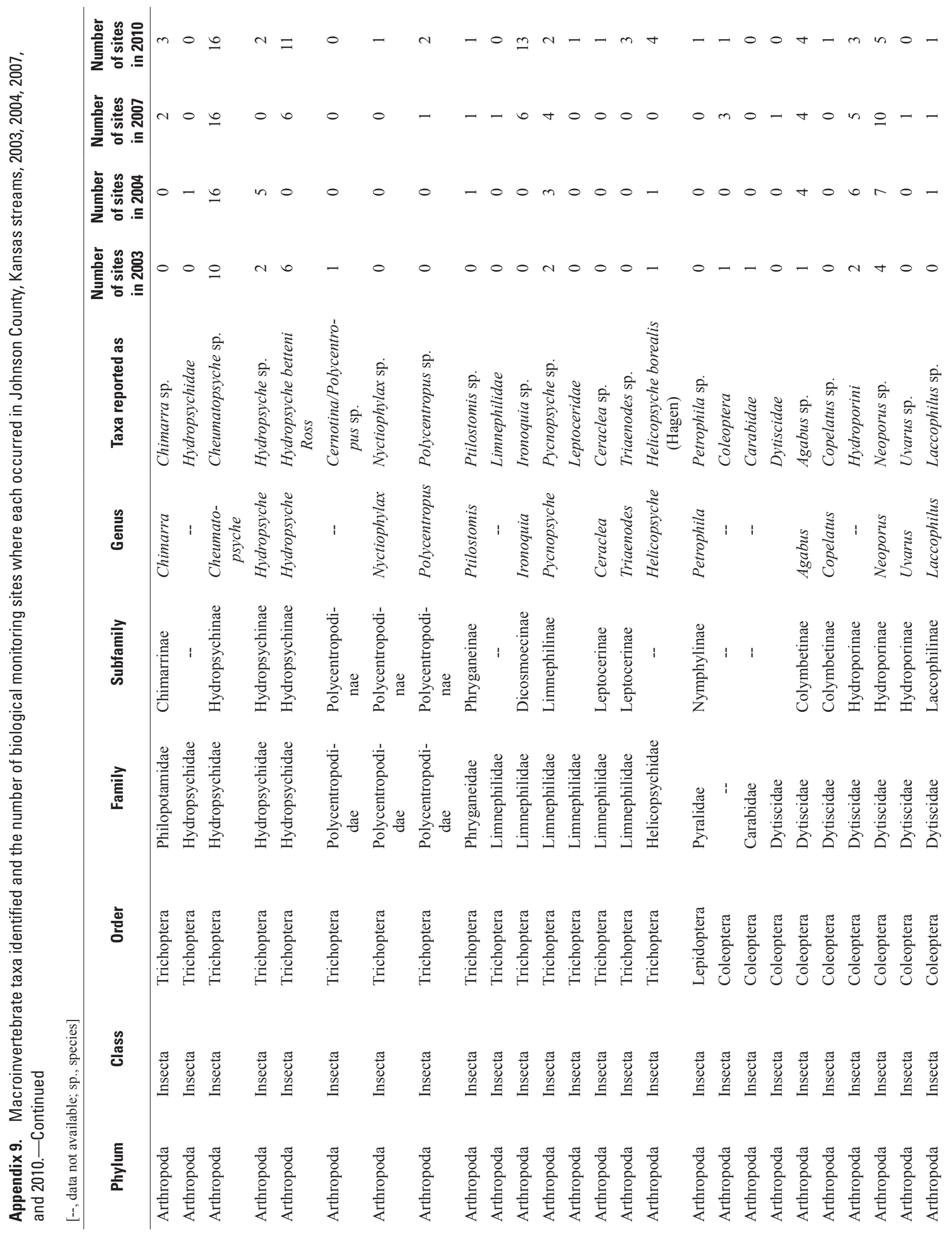




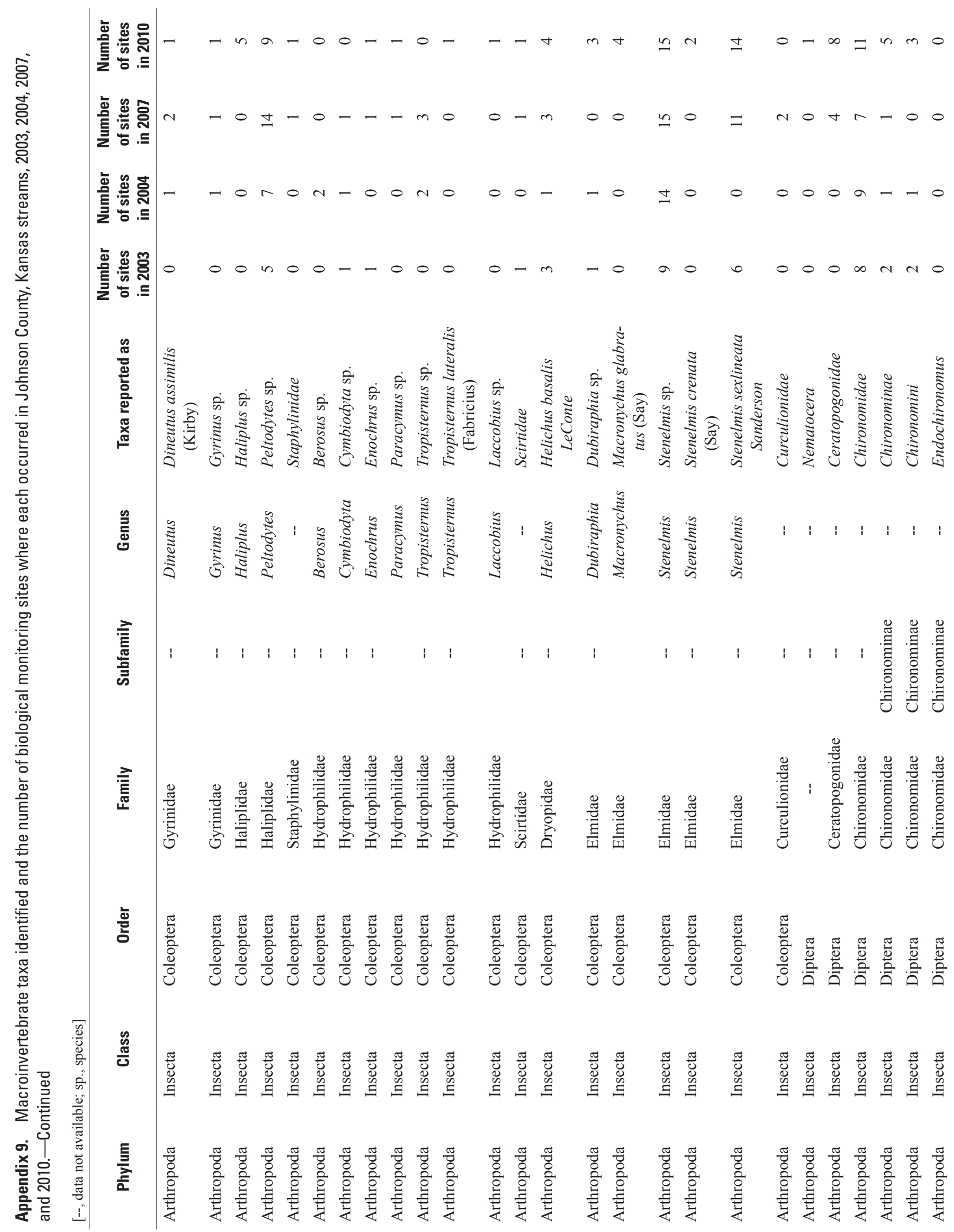




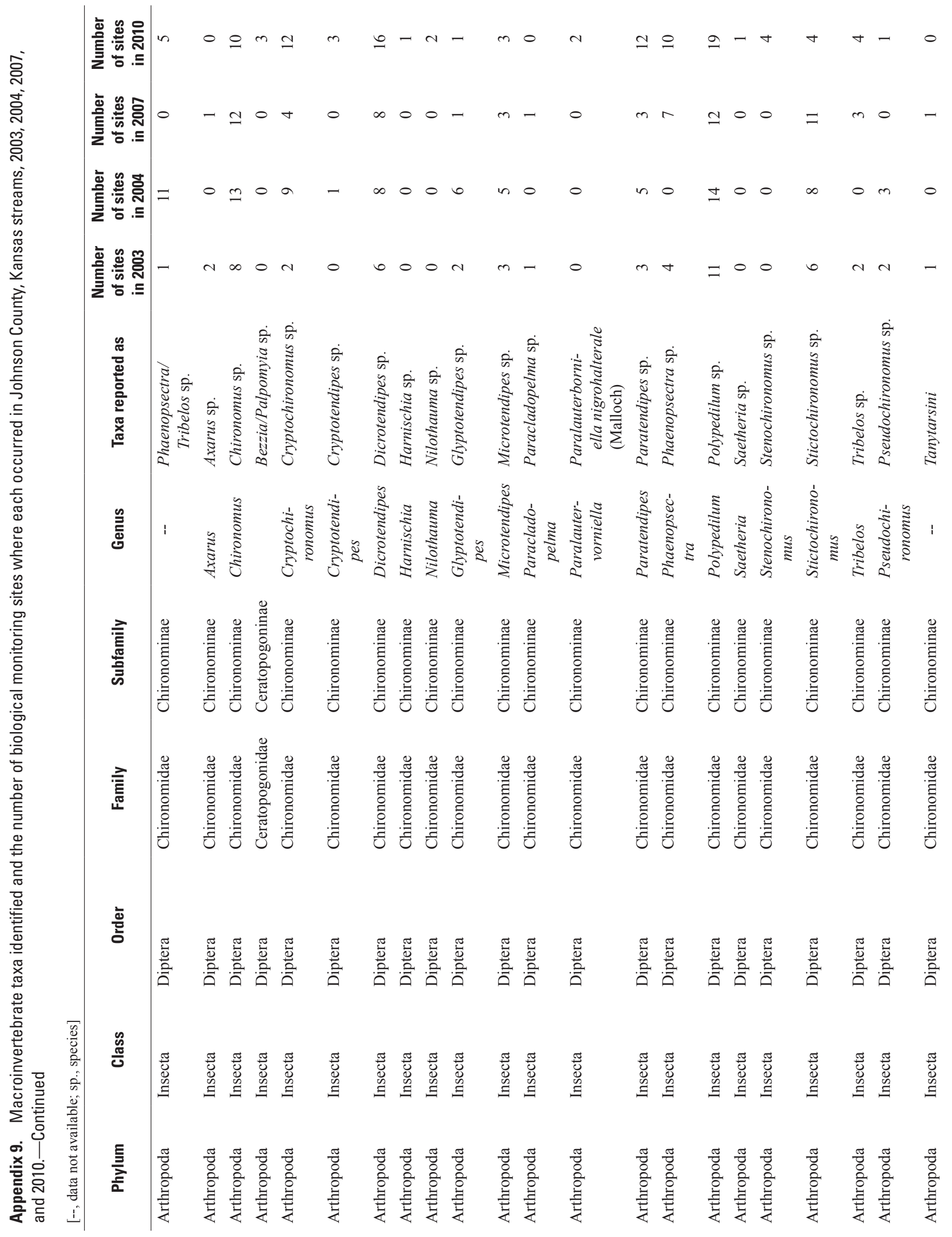




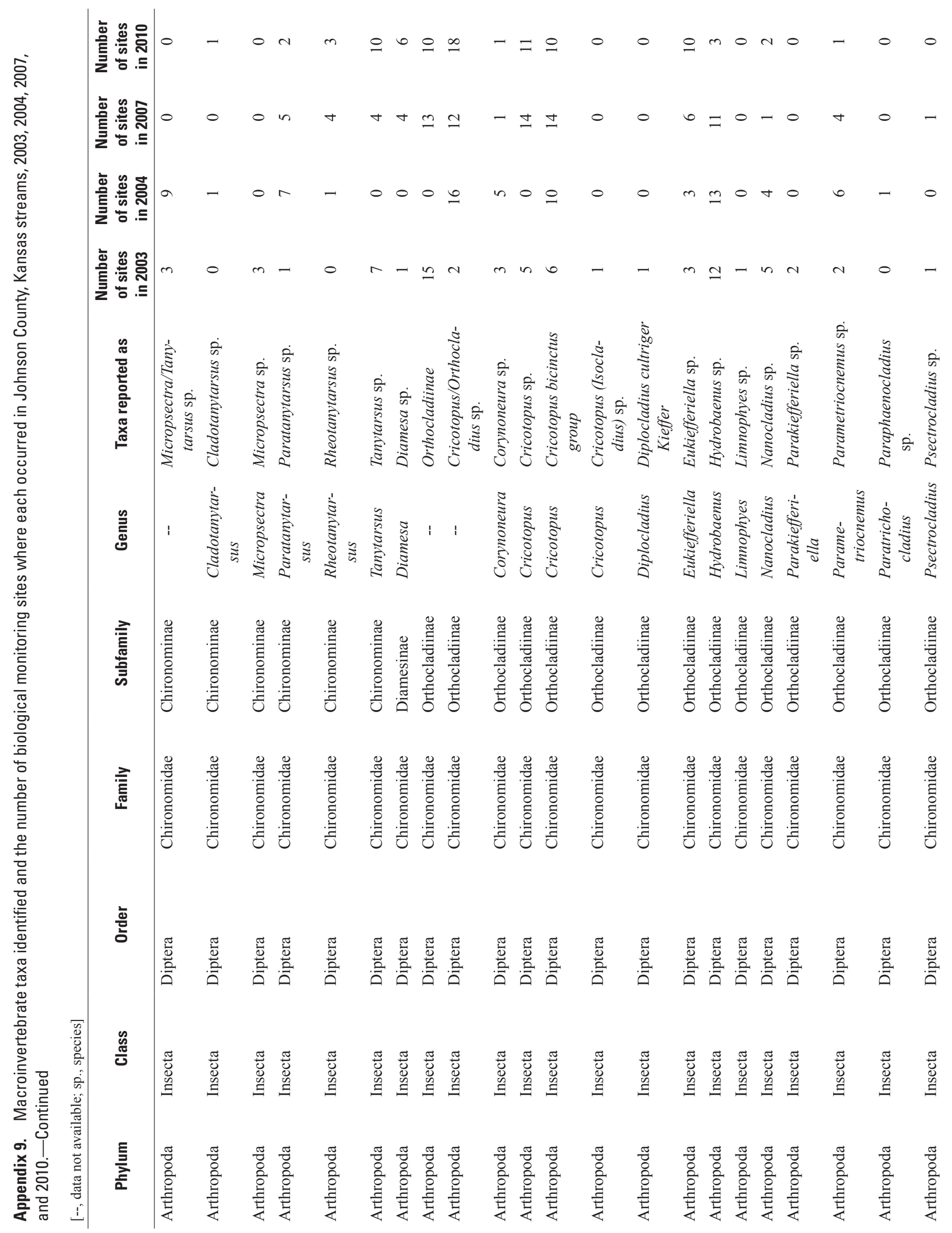




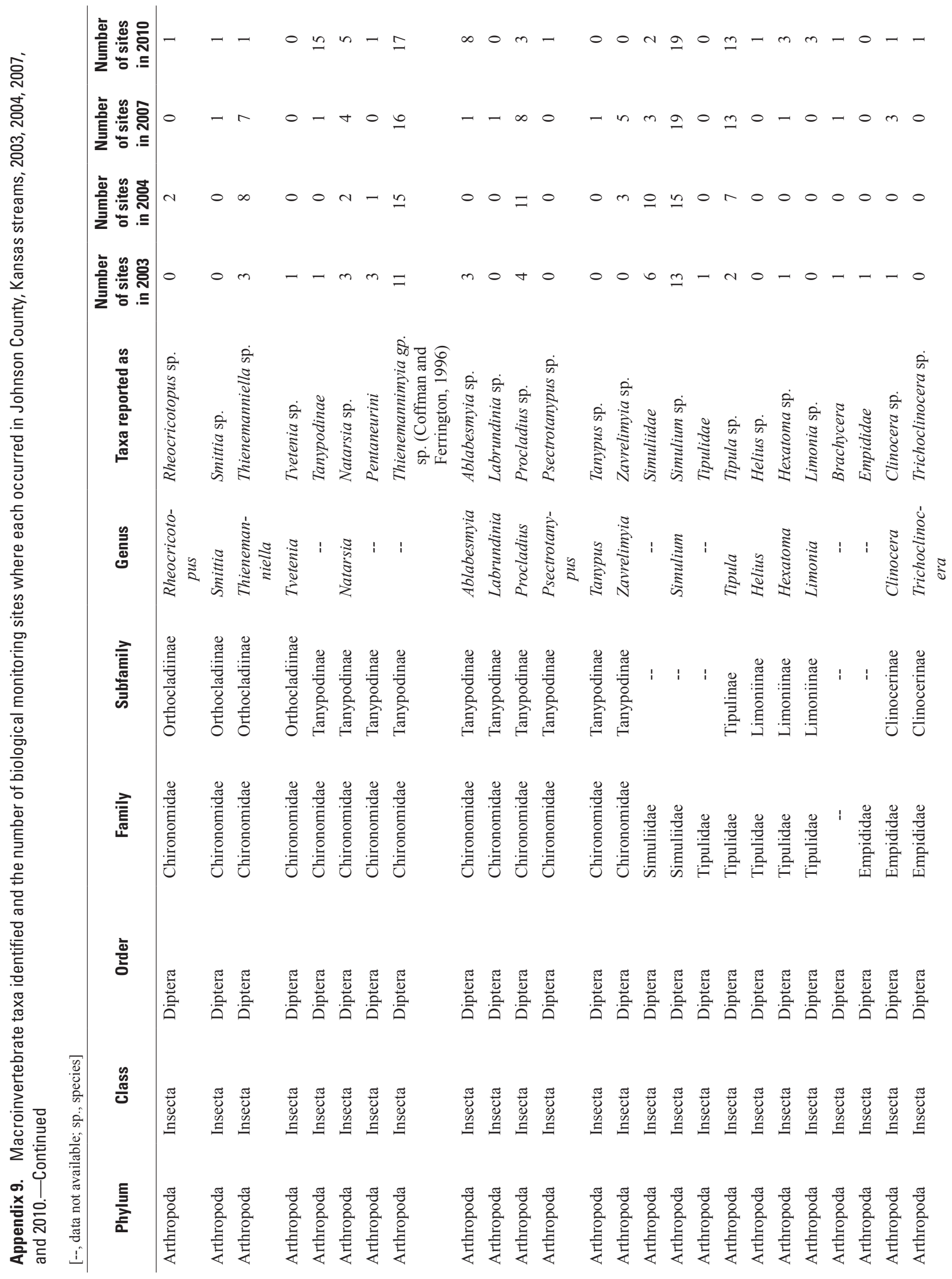




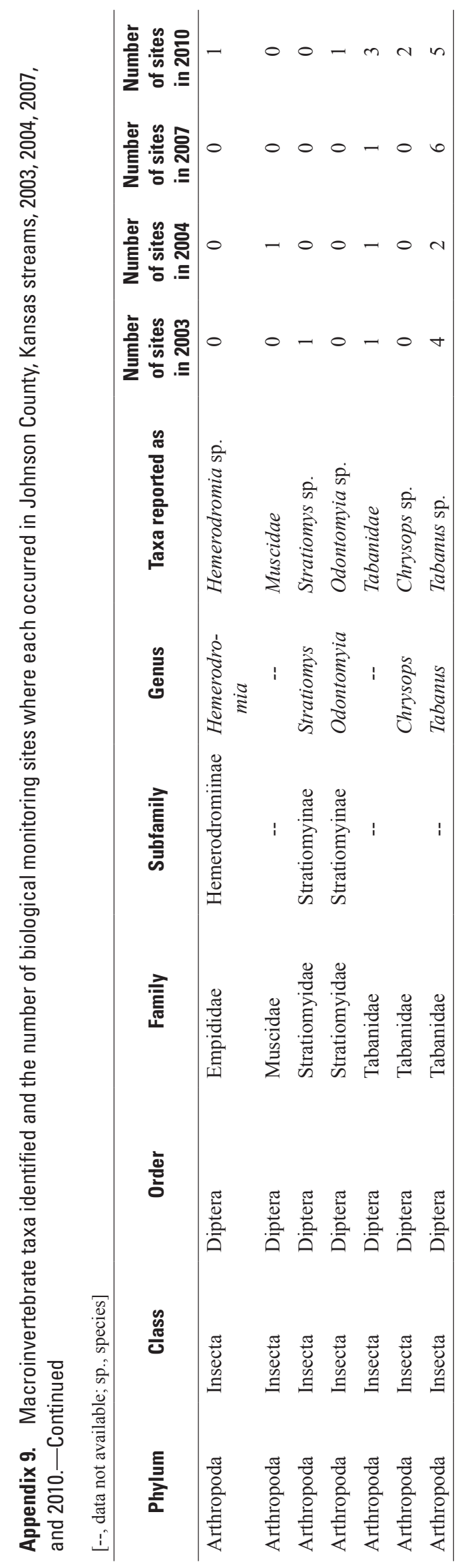


Publishing support provided by:

Rolla Publishing Service Center

For additional information concerning this publication, contact: Director, USGS Kansas Water Science Center

4821 Quail Crest Place

Lawrence, KS 66049

(785) 842-9909

Or visit the Kansas Water Science Center Web Site at: http://ks.water.usgs.gov 



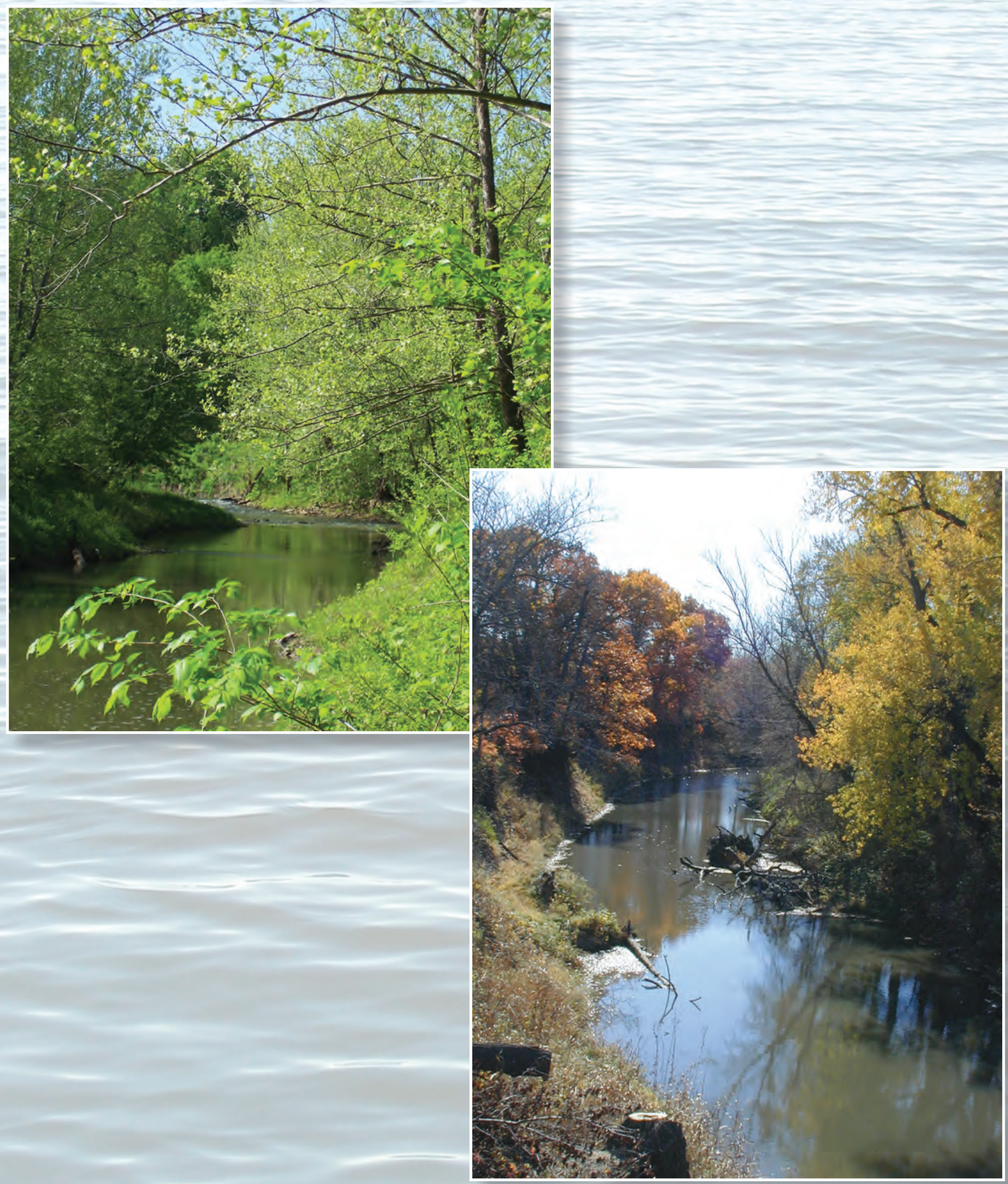

